Prepared in cooperation with New York City Department of Environmental Protection and

New York State Department of Environmental Conservation

\title{
Ground-Water Resources of Kings and Oueens Counties, Long Island, New York
}

\section{Water-Supply Paper 2498}
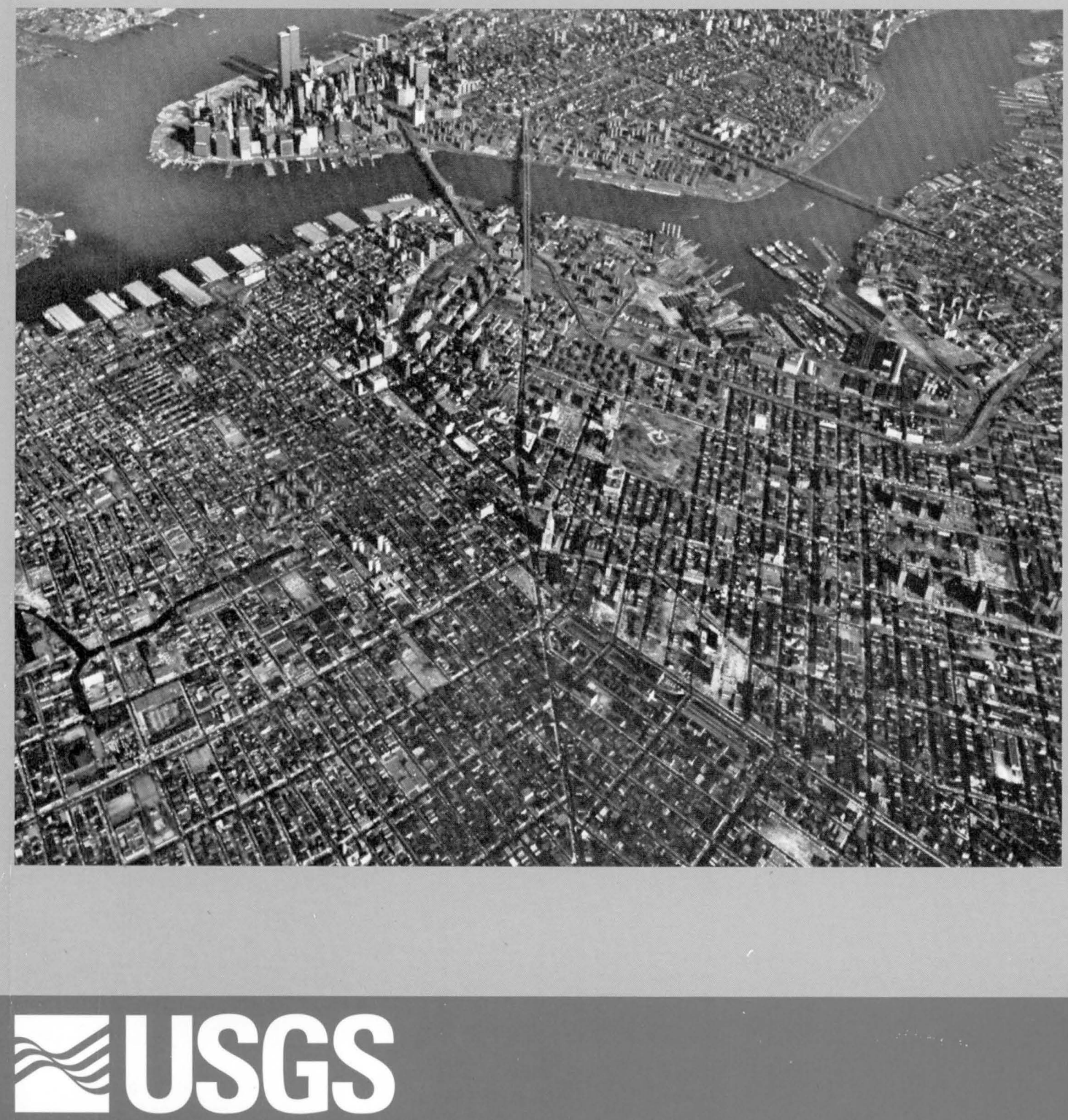


\section{Availability of Publications of the U.S. Geological Survey}

Order U S Geological Survey (USGS) publications from the offices listed below Detarled ordenng instructions, along with prices of the last offerings, are given in the current-year issues of the catalog "New Publications of the U S Geological Survey"

\section{Books, Maps, and Other Publications}

\section{By Mall}

Books, maps, and other publications are avallable by mall from-

USGS Information Services

Box 25286, Federal Center

Denver, CO 80225

Publications include Professional Papers, Bulletıns, WaterSupply Papers, Techniques of Water-Resources Investigations, Circulars, Fact Sheets, publications of general interest, single copies of permanent USGS catalogs, and topographic and thematic maps

\section{Over the Counter}

Books, maps, and other publications of the U S Geological Survey are avallable over the counter at the following USGS Earth Science Information Centers (ESIC's), all of which are authorized agents of the Superintendent of Documents

- Anchorage, Alaska-Rm 101, 4230 University Dr

- Denver, Colorado-Bldg 810, Federal Center

- Menlo Park, Calıfornı-Rm 3128, Bldg 3, 345 Middlefield Rd

- Reston, Virginia-Rm 1C402, USGS National Center, 12201 Sunrise Valley Dr

- Salt Lake City, Utah-2222 West, 2300 South (books and maps avallable for inspection only)

- Spokane, Washington-Rm 135, U S Post Office Building, 904 West Riverside Ave

- Washington, D C - Rm 2650, Main Interior Bldg, 18th and C Sts , NW

Maps only may be purchased over the counter at the following USGS office

- Rolla, Missouri-1400 Independence Rd

\section{Electronically}

Some USGS publications, including the catalog "New Publications of the U S Geological Survey" are also avallable electronically on the USGS's World Wide Web home page at http://www.usgs.gov

\section{Preliminary Determination of Epicenters}

Subscriptions to the periodical "Prelıminary Determination of Epicenters" can be obtained only from the Superintendent of
Documents Check or money order must be payable to the Superintendent of Documents Order by mall from-

Superintendent of Documents

Government Printıng Office

Washıngton, DC 20402

\section{Information Periodicals}

Many Information Penodicals products are avallable through the systems or formats listed below

\section{Printed Products}

Printed copies of the Minerals Yearbook and the Mineral Commodity Summaries can be ordered from the Superintendent of Documents, Government Printing Office (address above) Printed copies of Metal Industry Indicators and Mineral Industry Surveys can be ordered from the Center for Disease Control and Prevention, National Institute for Occupational Safety and Health, Pittsburgh Research Center, PO Box 18070, Pittsburgh, PA 15236-0070

\section{Mines FaxBack: Return fax service}

1 Use the touch-tone handset attached to your fax machine's telephone jack (ISDN [digital] telephones cannot be used with fax machines )

2 Dial (703) 648-4999

3 Listen to the menu options and punch in the number of your selection, using the touch-tone telephone

4 After completıng your selection, press the start button on your fax machine

\section{CD-ROM}

A disc containing chapters of the Minerals Yearbook (199395), the Mineral Commodity Summaries (1995-97), a statıst1cal compendium (1970-90), and other publications is updated three tımes a year and sold by the Superintendent of Documents, Government Printıng Office (address above)

\section{World Wude Web}

Minerals information is avallable electronically at http://mınerals.er.usgs.gov/minerals/

\section{Subscription to the catalog "New Publications of the U.S. Geological Survey"}

Those wishing to be placed on a free subscription list for the catalog "New Publications of the U S Geological Survey" should write to-

U S Geological Survey

903 National Center

Reston, VA 20192 
U.S. Department of the Interıor

U.S. Geological Survey

\section{Ground-Water Resources of Kings and Queens Counties, Long Island, New York}

By

Herbert T. Buxton and Peter K. Shernoff

Water-Supply Paper 2498

In cooperation with

New York City Department of Environmental Protection and NewYork State Department of Environmental Conservatıon 


\section{U.S. DEPARTMENT OF THE INTERIOR}

Bruce Babbitt, Secretary

\section{U.S. GEOLOGICAL SURVEY \\ Charles G. Groat, Dırector}

The use of firm, trade, and brand names in this report

is for identification purposes only and does not constitute

endorsement by the U S Government

\section{9}

\section{Lıbrary of Congress Catalogıng in Publications Data}

Buxton, Herbert T

Ground-water resources of Kings and Queens counties, Long Island, New York / by Herbert T Buxton and Peter K Shernoff p cm - (U S Geological Survey water-supply paper , 2498)

Includes biblıographical references

ISBN 0-607-92495-0

1 Groundwater-New York (State)-Kıngs County 2 Groundwater-NewYork (State)-Queens County I Shernoff, Peter K II Title III Series

GB1025 N7B89 1999

$5537^{\prime} 9^{\prime} 0974723-\mathrm{dc} 21$

99-30208

CIP

For sale by U S Geological Survey, Branch of Information Services

Box 25286, Federal Center

Denver, CO 80225

Cover-Aerıal photo of Brooklyn, New York, lookıng northwest toward Manhattan Island (NASA) 


\section{CONTENTS}

Abstract

$\begin{array}{lr}\text { Introduction } & 1\end{array}$

Purpose and Scope $\quad 3$

Acknowledgments 3

Hydrogeologic Framework $\quad 3$

Hydrostratigraphy 23

$\begin{array}{ll}\text { Upper Cretaceous Deposits } & 5\end{array}$

Lloyd Sand Member of the Raritan Formation $\quad 5$

$\begin{array}{ll}\text { Clay Member of the Raritan Formation } & 7\end{array}$

Magothy Formation and Matawan Group $\quad 7$

$\begin{array}{ll}\text { Pleistocene Deposits } & 7\end{array}$

$\begin{array}{ll}\text { Jameco Gravel } & 7\end{array}$

Gardıners Clay $\quad 9$

Upper Pleistocene Deposits $\quad 12$

Water-Transmittıng Properties $\quad 12$

Lloyd Aquifer 12

$\begin{array}{ll}\text { Jameco-Magothy Aquifer } & 13\end{array}$

Upper-Glacial Aquifer $\quad 13$

$\begin{array}{lllll}\text { Predevelopment Hydrologic Conditions } & \ldots & \ldots & \text {. } & 13\end{array}$

Water-Table Configuration $\quad 14$

Water Budget $\quad 16$

$\begin{array}{lr}\text { Ground-Water Qualıty } & 16\end{array}$

Nitrate $\quad$. 17

$\begin{array}{lr}\text { Silica } & 17\end{array}$

Iron $\quad 17$

$\begin{array}{ll}\text { Sulphate } & 17\end{array}$

Hardness $\quad 19$

Sodıum $\quad 19$

$\begin{array}{lr}\text { Chloride } & 19\end{array}$

Dissolved Solids $\quad 19$

Effects of Urbanization on the Hydrologic System $\quad 19$

$\begin{array}{ll}\text { Development of Ground-Water Supply } & 20\end{array}$

History of Ground-Water Development 20

1900 to $1917 \quad 20$

1918 to $1930 \quad 20$

1931 to $1946 \quad 20$

1947 to $1983 \quad 21$

Development of Individual Aquifers 22

Declınes in Water Levels $\quad$. 23 
$\begin{array}{lr}\text { Deterioration of Ground-Water Quality } & 29\end{array}$

$\begin{array}{lr}\text { Chloride } & 29\end{array}$

$\begin{array}{ll}\text { Nitrate } & 31\end{array}$

Recent Hydrologic Conditions (1983) $\quad 35$

Water-Table and Potent1ometric-Surface Altıtudes $\quad 35$

Water-Table Configuration $\quad 36$

Potentiometric Surface of the Jameco-Magothy Aquifer 36

Potentiometric Surface of the Lloyd Aquifer

Distribution of Hydraulic Head along Selected Vertical Sectıons 41

$\begin{array}{ll}\text { Water Budget } & 43\end{array}$

Inflow $\quad 43$

$\begin{array}{ll}\text { Outflow } & 44\end{array}$

$\begin{array}{ll}\text { Ground-Water Quality } & 44\end{array}$

Extent of Human-Induced Contamination 45

Contamination from Land Surface $\quad 45$

Saltwater Intrusion $\quad$ ` 53

Inorganic Constituents $\quad 54$

Upper Glacial Aquifer $\quad 54$

Jameco-Magothy Aquifer $\quad 55$

Lloyd Aquifer $\quad 55$

Organic Constituents $\quad 55$

$\begin{array}{ll}\text { Ground-Water-Resource Concerns } & 56\end{array}$

$\begin{array}{ll}\text { Summary } & 57\end{array}$

$\begin{array}{lr}\text { References Cited } & 57\end{array}$

\section{PLATES}

[Plates are in pocket]

Plate 1 Map showing location of wells used to determine altitude of tops of geologic units in Kings and Queens Counties, Long Island, New York

2 Hydrogeologic sections in Kıngs and Queens Countıes, Long Island, New York

Plates 3-5 Maps showing

3 Water-table configuration in Kıngs and Queens Counties, Long Island, New York, March-April 1983

4 Potentiometric-surface altitude in the Jameco-Magothy aquifer in Kıngs and Queens Countıes, Long Island, New York, March-Aprıl 1983

5 Potentiometric-surface altıtude in the Lloyd aquifer in Kıngs and Queens Counties, Long Island, New York, March-April 1983

6 Hydrogeologic sections showing head distribution withın hydrogeologic sections in Kings and Queens Count1es, Long Island, New York

7 Map showing location of wells sampled from March to October 1983, in Kings and Queens Counties Long Island, New York 


\section{FIGURES}

Figure 1 Map showing locatıon of Kıngs, Queens, and western Nassau County study area, Long Island, New York

Figures $\quad 2 \mathrm{~A}-2 \mathrm{~F}$ Maps showing altitude of top of.

2A Crystalline bedrock 5

2B Lloyd Sand Member of the Raritan Formation 6

2C Clay member of the Raritan Formation $\quad 8$

2D Magothy Formation and Matawan Group 9

2E Jameco Gravel 10

2F Gardıners Clay 11

3 Hydrogeologic sectıon showing estımated flow patterns along sectıon $B-B$ ' under predevelopment conditions

4 Map showing water table in 1903

5-6 Graphs showing

5 Annual average pumpage for industrial and public supply in Kıngs and Queens Counties, 1904-83

6 Annual average public-supply pumpage from individual aquifers in Kings County and Queens County, 1904-83

7A -7E Maps showing water table configuration in

7A 1936

7B 1943

7C 1951

7D 1961.

7E 1974

8 Graph showing total pumpage and average chloride concentration from eight driven wells at the Shetucket pumping station, 1897-1905

9 Graphs showing chloride concentratıon in water from selected wells in Kıngs and Queens Counties $(A)$ Wells screened in the upper glacial aquifer $(B)$ Wells screened in the Jameco aquifer

10A -10C Maps showing chloride concentrations in the upper glacial aquifer in Kings and Queens Counties in

$10 \mathrm{~A} 1947$

10B 1961

10C 1970

11-15B Maps showing

11 Upper surface altitude of deposits with low permeability at base of water-table aquifer in northern Kıngs and Queens Counties

12 Distribution of hydraulic head in southern Queens and southwestern Nassau County, as measured and converted to freshwater equivalent head

13A Chlonde concentrations in the upper glacial aquifer, 1983

13B Nitrate concentrations in the upper glacial aquifer, 1983

14A Chlonde concentrations in the Jameco-Magothy aquifer, 1983 
14B Nitrate concentrations in the Jameco-Magothy aquifer, 198349

15A Chloride concentrations in the Lloyd aquifer, 198350

15B Nitrate concentrations in the Lloyd aquifer

16 Hydrogeologic sections showing nitrate and chloride concentrations along sections $C-C^{\prime}$, $D-D^{\prime}$, and $E-E^{\prime}$

\section{TABLES}

Table 1 Western Long Island stratigraphic column with geologic and hydrogeologic interpretation 4

2 Predevelopment ground-water budget

3 Chemical composition of Long Island ground water and precipitation under predevelopment conditions

4 Number of observation wells in which water levels were measured, January through April $1983 \quad 35$

5 Equivalent freshwater head at wells affected by salıne water in the Jameco-Magothy aquifer $\quad 40$

6 Water budgets for predevelopment and recent conditions

7 Wells and test borings plotted on plate 1 that occupy a multiple well site

8 Observation wells whose records were used to produce maps of water-table and potentiometricsurface altitudes

9 Hydrogeologic units penetrated by wells and test holes in Kıngs, Queens, Nassau, Bronx, New York, and Richmond Counties, New York

10 Selected chemical analyses of ground water sampled from observation wells in Kings, Queens, and western Nassau Counties, New York

11 Selected chemical analyses of ground water sampled from public-supply wells in Kings, Queens, and western Nassau Counties, New York 


\title{
CONVERSION FACTORS, VERTICAL DATUM, AND ABBREVIATIONS
}

\begin{tabular}{|c|c|c|c|}
\hline & Multıply & By & To obtain \\
\hline & $\operatorname{lnch}(\mathrm{nn})$ & 254 & millımeter \\
\hline \multirow[t]{12}{*}{. } & foot $(\mathrm{ft})$ & 03048 & meter \\
\hline & mile (mı) & 1609 & kılometer \\
\hline & acre & 04047 & hectare \\
\hline & square mile $\left(\mathrm{mi}^{2}\right)$ & 2590 & square kılometer \\
\hline & gallon (gal) & 3785 & liter \\
\hline & million gallons (Mgal) & 3,785 & cubic meter \\
\hline & billion gallons (Bgal) & $3,785,000$ & cubic meter \\
\hline & Inch per year (In/yr) & 254 & millımeter per year \\
\hline & foot per day $(\mathrm{ft} / \mathrm{d})$ & 03048 & meter per day \\
\hline & Foot per mile $(\mathrm{ft} / \mathrm{mı})$ & 01894 & meter per kılometer \\
\hline & gallon per minute (gal/mın) & 3785 & liter per mınute \\
\hline & millıon gallons per day $(\mathrm{Mgal} / \mathrm{d})$ & 3,785 & cubic meter per day \\
\hline & ay per square mile $\left[(\mathrm{Mgal} / \mathrm{d}) / \mathrm{mi}^{2}\right]$ & 1,461 & cubic meter per day per square kılometer \\
\hline
\end{tabular}

Temperature is given in degrees Celsius $\left({ }^{\circ} \mathrm{C}\right)$, which can be conve.ted to degrees Fahrenheit $\left({ }^{\circ} \mathrm{F}\right)$ by use of the following equation

$$
{ }^{\circ} \mathrm{F}=18^{\circ} \mathrm{C}+32
$$

Sea level. In this report, "sea level" refers to the National Geodetic Vertical Datum of 1929 (NGVD of 1929)-a geodetıc datum derived from a general adjustment of the first-order level nets of both the United States and Canada, formerly called Sea Level Datum of 1929

\begin{abstract}
Abbreviated water-quality units used in this report: Chemical concentrations and water temperature are given in metric units Chemical concentration is given in milligrams per liter $(\mathrm{mg} / \mathrm{L})$ or micrograms per liter $(\mu \mathrm{g} / \mathrm{L})$ Milligrams and micrograms per liter are units expressing the concentration of chemical constituents in solution as weight (milligrams or micrograms) of solute per unit volume (liter) of water Onethousandth gram per liter is equivalent to one milligram per liter One-millionth gram per liter is equivalent to one microgram per hiter For concentrations less than $7,000 \mathrm{mg} / \mathrm{L}$, the numerical value is approxımately the same as for concentrations in parts per million
\end{abstract}




\title{
Ground-Water Resources of Kings and Queens Counties, Long Island, New York
}

\author{
By Herbert T Buxton and Peter K Shernoff
}

\section{Abstract}

The aquifers beneath Kungs and Queens Counties supplied an average of more than 120 $\mathrm{Mgal} / \mathrm{d}$ (million gallons per day) for industrial and public water supply during $1904-47$, but this pumping caused saltwater intrusion and a deterioration of water quality that led to the cessation of pumping for public supply in Kings County in 1947 and in western Queens County in 1974 Since the cessation of pumping in Kings and western Queens Counties, ground-water levels have recovered steadıly, and the saltwater has partly dispersed and become diluted In eastern Queens County, where pumpage for public supply averages $60 \mathrm{Mgal} / \mathrm{d}$, all three major aquifers contain a large cone of depression The saltwater-freshwater interface in the Jameco-Magothy aquifer already extends inland in southeastern Queens County and is moving toward this cone of depression. The pumping centers' proximity to the north shore also warrants monitoring for saltwater intrusion in the Flushing Bay area

Urbanization and development on western Long Island since before the turn of this century have caused significant changes in the groundwater budget (total inflow and outflow) and patterns of movement Some of the major causes are (1) intensive pumping for industrial and public supply, (2) paving of large land-surface areas, (3) installation of a vast network of combined (storm and sanitary) sewers, (4) leakage from a watersupply-line network that carries more than 750 $\mathrm{Mgal} / \mathrm{d}$, and (5) burial of stream channels and extensive wetland areas near the shore
Elevated nitrate and chloride concentrations throughout the upper glacial (water-table) aquifer indicate widespread contamination from the land surface Localized contamination in the underlying Jameco-Magothy aquifer is attributed to downward migration in areas of hydraulic connection between aquifers where the Gardiners Clay is absent. A channel eroded through the Raritan confining unit provides a pathway for migration of surface contaminants to the Lloyd aquifer sooner than anticipated Although ground water in the Lloyd aquifer is still pristine, present pumping rates and potentiometric levels in the Lloyd aquifer indicate that it is much more sensitive to withdrawals than the other aquifers are and contans an extremely limited water supply

\section{INTRODUCTION}

Kıngs and Queens Counties (the boroughs of Brooklyn and Queens in New York City) are at the western end of Long Island (fig 1) This area has been extensively urbanized for more than 100 years In 1990, the population of Kings County was 23 million, and the population of Queens was 20 million The Long Island ground-water system, including the part beneath Kings and Queens Counties, is the sole source of water supply for the 26 million inhabitants of Nassau and Suffolk Counties to the east

Ground water has been a source of public supply for western Long Island since the mid-19th century Rapid increases in population since the turn of this century, and the attendant increases in pumping for public supply and industry, have resulted in severe water-level declines and intrusion of saline water from the surrounding bays As a result, pumpıng for public supply 


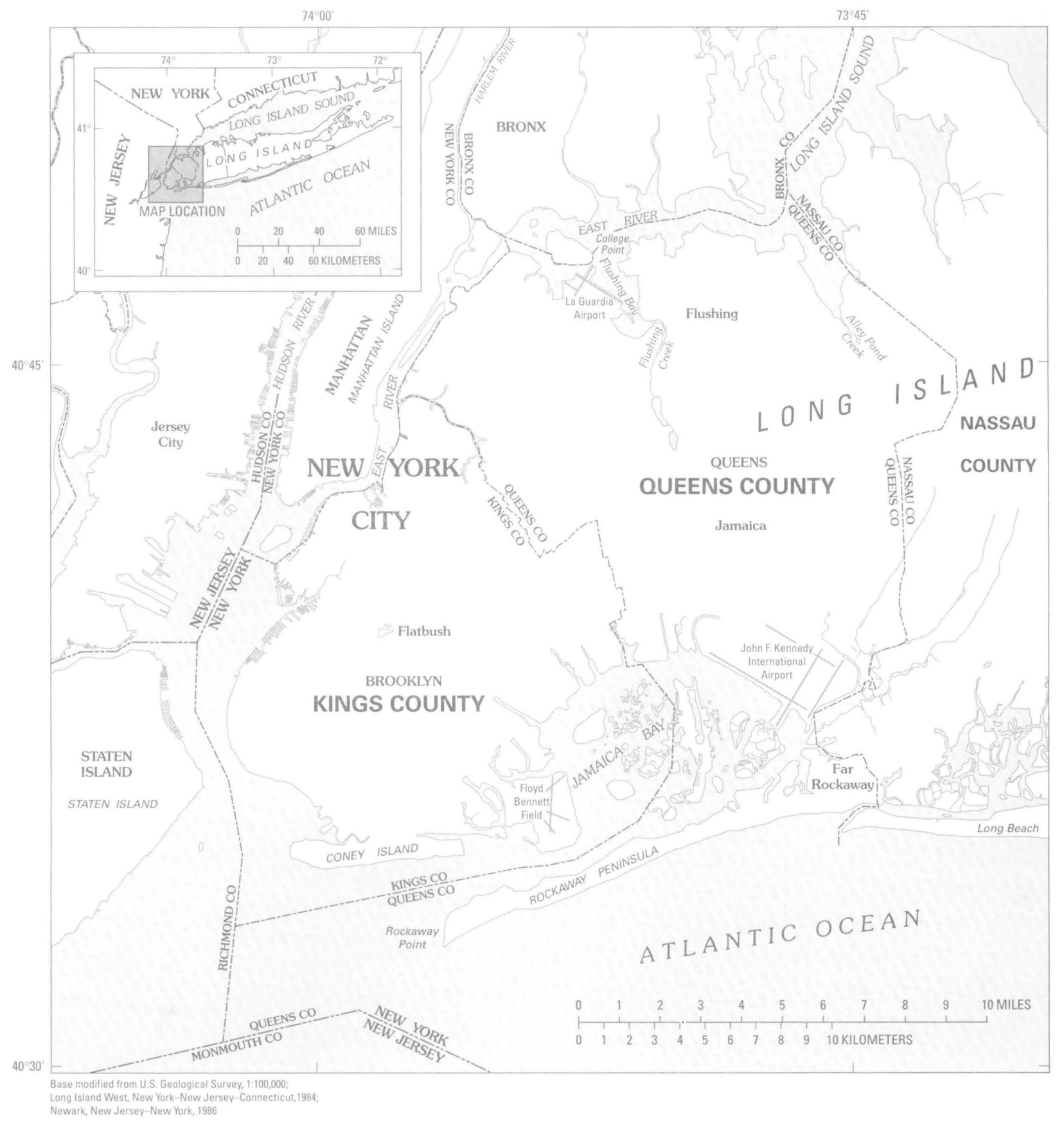

Figure 1. Location of Kings, Queens, and western Nassau County study area, Long Island, New York.

in Kings County was stopped in 1947 and in western Queens County in 1974. (These areas now obtain water from mainland surface-water reservoirs.) As the early pumping centers in Kings and western Queens County were abandoned, new ones were established farther east in areas more distant from the shore, where water-table altitudes are higher.

Since the cessation of pumping, water levels in Kings and western Queens Counties have recovered continually. Even in areas where the water table had been drawn down to as much as $35 \mathrm{ft}$ below sea level, it is now above sea level. In many of these areas, subways and deep basements that were constructed in the early 20 th century, when water levels were depressed, are now being flooded as the water table recovers and need to be dewatered continually. By 1983, eastern Queens County was withdrawing almost $60 \mathrm{Mgal} / \mathrm{d}$ for public 
supply, enough to cause concern that salt-water intrusion may resume

In 1981-86, the U S Geological Survey (USGS) conducted an investigation of the western part of the Long Island ground-water system in cooperation with the New York State Department of Environmental Conservation and the New York City Department of Env1ronmental Protection The area included all of Kings (about $76 \mathrm{mi}^{2}$ ) and Queens (about $113 \mathrm{mi}^{2}$ ) Counties and about $50 \mathrm{mi}^{2}$ in westernmost Nassau County

(fig 1)

\section{Purpose and Scope}

This report describes the structure and operation of the western part of the Long Island ground-water system It describes the hydrologic effects associated with human development in this highly urbanızed env1ronment from 1900 to the early 1980's The groundwater quantity and quality of recent (early 1980's) conditions is characterized and a discussion of groundwater resource concerns is offered Specifically, it

1 delineates the hydrogeologic framework of the western part of the Long Island ground-water system and defines its water-bearıng characteristics,

2 describes ground-water flow patterns, the groundwater-system budget, and ground-water quality under predevelopment conditions,

3 summarizes the development of the ground-water system and the effects of urbanization by presenting historical pumpage data and other urbanizing factors, and presentıng the subsequent response of the ground-water system, and

4 presents the recent patterns and distribution of ground-water flow, and concentrations of selected chemical constituents that indicate the extent of human-derived contamination and saltwater intrusion throughout the ground-water system

\section{Acknowledgments}

The authors thank the New York State Department of Environmental Conservation and the New York City Department of Environmental Protection for support and cooperation Special thanks are given to Jerry Iwan and the staff of the Bureau of Water Supply Laboratory of the New York City Department of Environmental Protection for cooperation in handling and chemical analysis of water samples

\section{HYDROGEOLOGIC FRAMEWORK}

The ground-water system that underlies western Long Island consists of a series of unconsolidated deposits of clay, sand, and gravel of Late Cretaceous and Pleistocene age that are underlain by Precambrian(?) bedrock The stratigraphic relations of the geo$\log _{1} \mathrm{c}$ units are summarized in table 1 , the geometry of these units is depicted in vertical sections on plate 2 and in hydrogeologic maps in figures $2 \mathrm{~A}-\mathrm{F}$ The watertransmitting properties of the corresponding hydrogeo$\log _{1} \mathrm{c}$ units are described also

\section{Hydrostratigraphy}

Bedrock was eroded to a peneplain before deposition the overlyıng Cretaceous sediments, its surface shows signs of later erosion by Pleistocene glaciation in the northwest (fig 2A, see also sections A-A' and BB' on pl 2) Bedrock crops out in northwestern Queens County near the East River and slopes southeastward at about $80 \mathrm{ft} / \mathrm{m} 1$ Consequently, the overlying unconsol1dated formations form a wedge-shaped mass that attains a maximum thickness of more than $1,100 \mathrm{ft}$ in the southeastern corner of Queens County The max1mum thickness in Kings County is about $900 \mathrm{ft}$, in southeastern Kings

Overlying bedrock is the Raritan Formation of Late Cretaceous age, which consists of the Lloyd Sand Member and an upper, unnamed clay member Overlying the Raritan Formation are the Magothy Formation and Matawan Group, undifferentiated, also of Late Cretaceous age, the Jameco Gravel and the Gardiners Clay, both of Pleistocene age, upper Pleistocene deposits of Wisconsin age, and a generally thin soil mantle of Holocene age (table 1 and pl 2) Holocene beach deposits form most of the Rockaway Peninsula and Coney Island in the south, and Holocene salt-marsh deposits underlie and fringe the south-shore bay areas Artificial filling has buried some marsh deposits in low and swampy shore areas Because Holocene deposits occur only in relatively small areas of Kings and Queens and are not significant water bearers, they are not included in the geologic descriptions that follow

Erosion of the Cretaceous strata from Late Cretaceous through Pleistocene time has created a complex buried topography, as is seen in sections on plate 2 The data from which the hydrogeologic correlations were formulated consisted mainly of drillers' geologic logs, geophysical data, descriptıve logs prepared by the 
Table 1 Western Long Island stratıgraphıc column with geologıc and hydrogeologıc interpretatıon

\begin{tabular}{|c|c|c|c|c|c|c|}
\hline System & Series & & ologic unıt & Hydrogeologıc unıt & $\begin{array}{l}\text { Range of } \\
\text { thickness, } \\
\text { in feet }\end{array}$ & $\begin{array}{c}\text { Range of } \\
\text { altitude of upper } \\
\text { surface, in feet } \\
\text { above or below } \\
\text { sea level }\end{array}$ \\
\hline \multirow{4}{*}{ 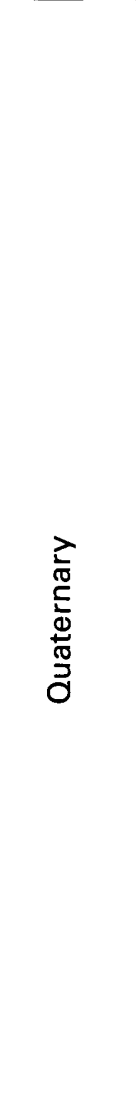 } & Holocene & \multicolumn{2}{|c|}{$\begin{array}{l}\text { Shore, beach salt-marsh } \\
\text { deposits, and alluvium }\end{array}$} & & & \\
\hline & \multirow{3}{*}{ 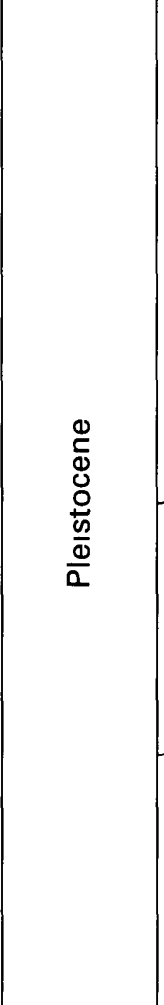 } & 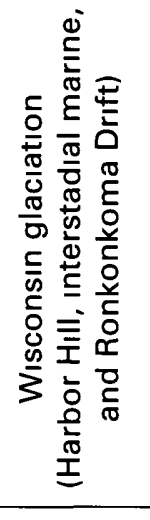 & $\begin{array}{l}\text { Till (ground and } \\
\text { termınal moraıne) } \\
\text { Outwash } \\
\text { "20-foot" clay } \\
\text { (marıne) } \\
\text { _unconformıty? }\end{array}$ & $\begin{array}{l}\text { Upper glacial } \\
\text { aquifer }\end{array}$ & 0 to 300 & Land surface \\
\hline & & 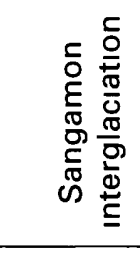 & $\begin{array}{l}\text { Gardıners Clay } \\
\text { (marıne) }\end{array}$ & $\begin{array}{l}\text { Gardıners } \\
\text { Clay }\end{array}$ & 0 to 150 & -40 to -200 \\
\hline & & 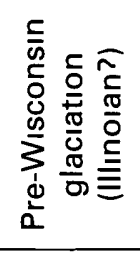 & Jameco Gravel & $\begin{array}{l}\text { Jameco } \\
\text { aquifer }^{1}\end{array}$ & 0 to 200 & -90 to -240 \\
\hline \multirow{3}{*}{ 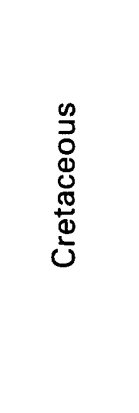 } & \multirow{3}{*}{ 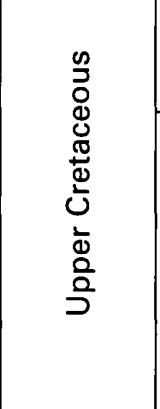 } & \multicolumn{2}{|c|}{$\begin{array}{l}\text { Matawan Group-Magothy } \\
\text { Formation (undifferentıated) }\end{array}$} & $\begin{array}{l}\text { Magothy } \\
\text { aquifer }^{1}\end{array}$ & 0 to 500 & 40 to -400 \\
\hline & & \multirow{2}{*}{ 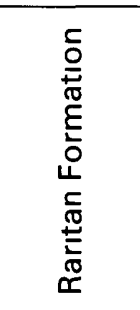 } & Clay member & $\begin{array}{c}\text { Rarıtan } \\
\text { confınıng unıt }\end{array}$ & 0 to 200 & 30 to -650 \\
\hline & & & $\begin{array}{l}\text { Lloyd sand } \\
\text { member }\end{array}$ & $\begin{array}{l}\text { Lloyd } \\
\text { aquifer }\end{array}$ & 0 to 300 & -90 to -825 \\
\hline \multicolumn{2}{|c|}{ Precambrian } & \multicolumn{2}{|c|}{ Crystallıne bedrock } & Bedrock & - & 15 to $-1,100$ \\
\hline
\end{tabular}

${ }^{1}$ The Magothy and Jameco aquifers are often considered as one hydrologıc unit with differıng hydraulıc propertıes (See discussion in text)

USGS during inspection of cores of well-bore samples, and selected bridge and tunnel-boring data These data are interpreted in relation to the area's erosional and depositional history The altitude of each hydrogeologic unit's upper surface at each well is listed in table
9 (at end of report), locations of wells are shown on plate 1 The numbers of all wells at multiple-well sites are given in table 7 (at end of report) to facilitate location of wells 


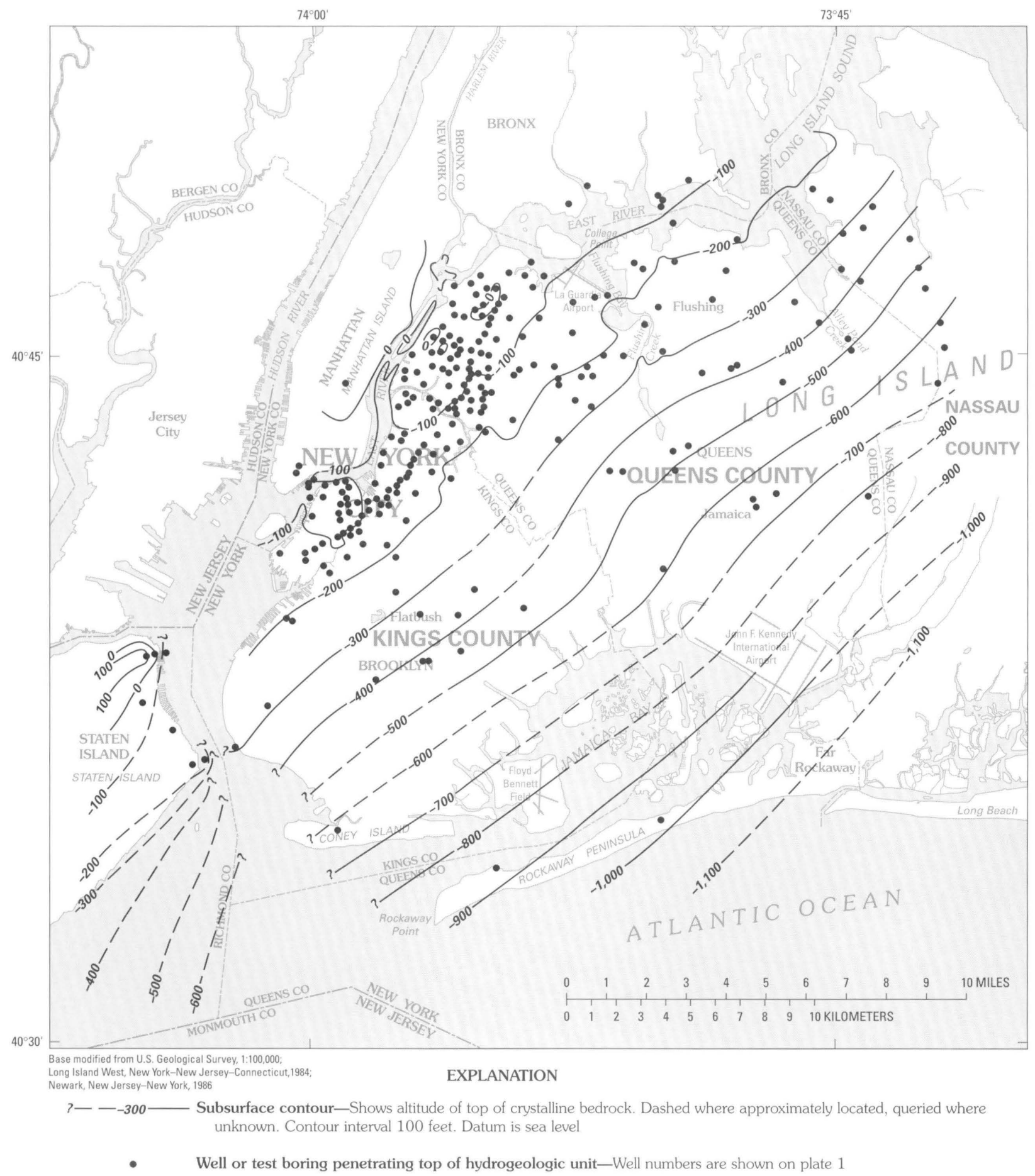

Figure 2A. Altitude of top of crystalline bedrock.

\section{Upper Cretaceous Deposits}

\section{Lloyd Sand Member of the Raritan Formation}

The Lloyd Sand Member, the oldest Cretaceous deposit in the area, lies unconformably on bedrock. Its surface and extent were shaped by post-Cretaceous erosion. It is absent in northwestern Kings and Queens Counties (fig. 2B) and in a tributary buried-valley-system that trends southward from Flushing Bay to central Queens County (section E-E', pl. 2). 


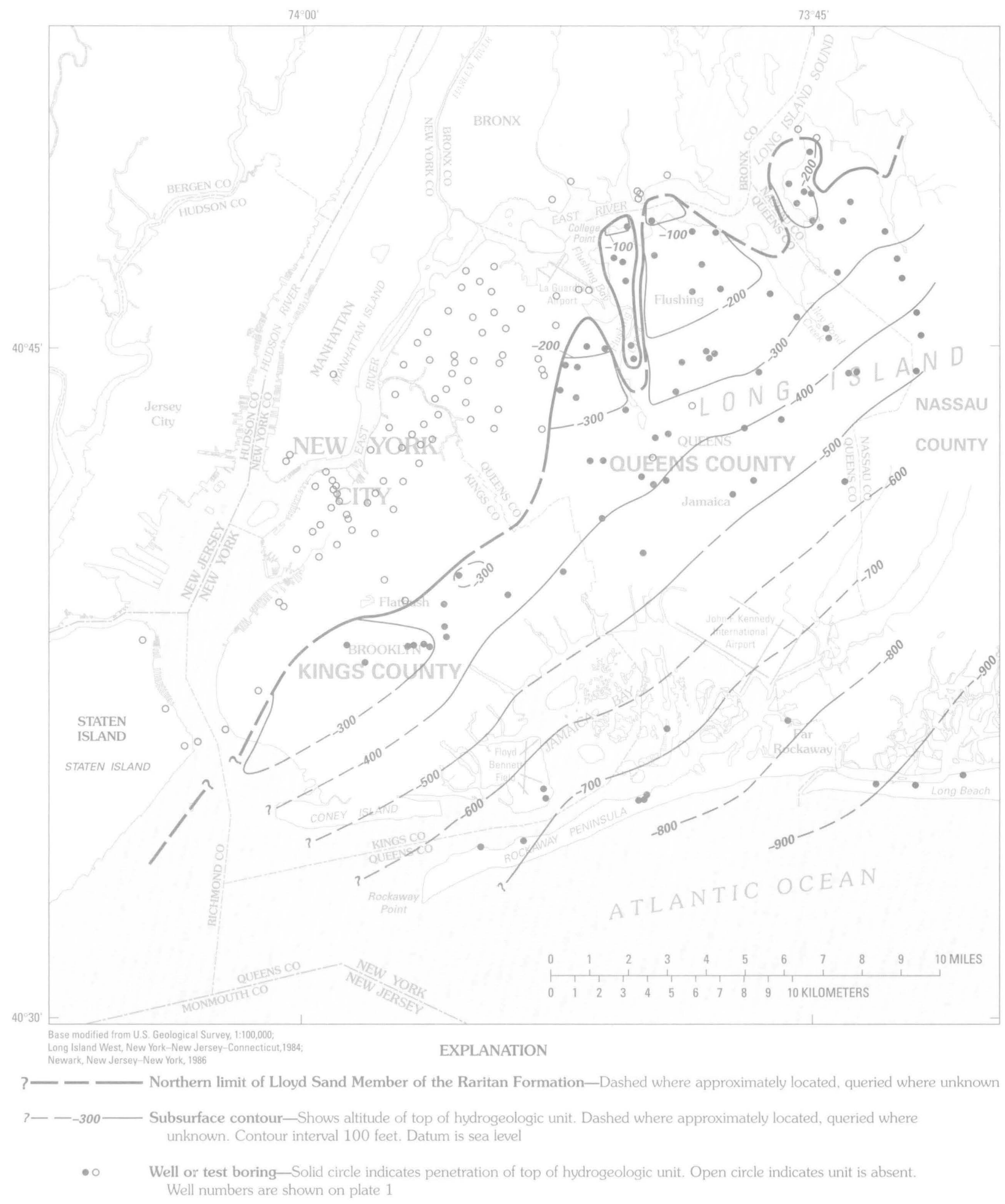

Figure 2B. Altitude of top of Lloyd Sand Member of the Raritan Formation.

The Lloyd Sand Member consists mainly of deltaic deposits of fine to coarse quartzose sand interbedded with sand and small- to large-pebble quartzose gravel. Interbeds of silt and clay and silty and clayey sand are common throughout the unit (Soren, 1978).
The member is overlain by the clay member of the Raritan Formation. The northern extent of the Lloyd Sand Member and the clay member are largely coincident where eroded in the buried-valley system in northern Queens (pl. 2), but the clay member extends well north 
of the underlying Lloyd Sand Member in western Queens and Kıngs Counties

The Lloyd Sand Member ranges in thickness from zero at its northern edge to about $200 \mathrm{ft}$ in southeastern Kings County and $300 \mathrm{ft}$ in southeastern Queens County The unit's surface 1s as high as $90 \mathrm{ft}$ below sea level in northern Queens and more than 800 $\mathrm{ft}$ below sea level in southeastern Queens

\section{Clay Member of the Raritan Formation}

This unit is absent along the northwest shore of Kings and Queens Counties (fig 2C) and is eroded in central Queens in the same buried-valley system as the Lloyd Sand Member, but the clay member has been more extensively eroded, especially to the south The clay member consists mainly of deltaic clay and silty clay beds and some interbedded sand (Soren, 1978) It increases in thickness from a pinchout at its northern limit to about $250 \mathrm{ft}$ in southeastern Kings County and about $200 \mathrm{ft}$ in southeastern Queens County Its upper surface is less than $50 \mathrm{ft}$ below sea level in Kings County and a few feet above sea level in parts of northern Queens It is more than $400 \mathrm{ft}$ below sea level in southern Kings and $600 \mathrm{ft}$ below sea level in southeastern Queens

The clay member overlies the Lloyd Sand Member with apparent conformity and, where the Lloyd Sand Member is absent, it lies unconformably on bedrock It was disconformably overlain by Upper Cretaceous deposits, but dunng a complex geologic history after the Late Cretaceous Epoch, it became overlain from south to north by the Magothy Formation and Matawan Group, undifferentiated, the Jameco Gravel, the Gardiners Clay, and upper Pleistocene deposits, respectively (pl 2)

\section{Magothy Formation and Matawan Group}

The Magothy Formation and Matawan Group, undifferentiated, contains the remaining Cretaceous deposits in this area This uppermost Cretaceous unit was severely eroded from the Late Cretaceous to the tıme of deposition of the Jameco Gravel (fig 2D) The erosion is most severe in what was probably a complex channel network from an ancestral diversion of the Hudson River (Soren, 1978, p 12-15) The Cretaceous unit in Kings and Queens Counties has a buried erosional surface with two prominent north-south trending channels, one through central Queens and one generally parallel to the Kings-Queens County line These channels are eroded through the unit to near the south shore, where they apparently join and contınue south as a single channel Where the unit has been completely removed, dissection is evident in the underlying clay member and Lloyd Sand Member of the Raritan Formation (fig 2B and 2C) and even in the bedrock in a small area of north-central Queens (fig 2A)

The deposits of the Magothy Formation and Matawan Group, like the earlier Cretaceous deposits, are of contınental origin and are mostly deltaic quartzose very fine to coarse sand and silty sand with lesser amounts of interbedded clay and silt The unit commonly has a coarse quartzose sand and in many places a basal gravel zone 25 to $50 \mathrm{ft}$ thick

The unit ranges in thickness from zero at its northern limits to more than $200 \mathrm{ft}$ in southern Kings and $500 \mathrm{ft}$ in southeastern Queens It is thinner in the buried valleys The altitude of the Magothy-Matawan surface ranges from a few feet above sea level in northeast Queens to more than $400 \mathrm{ft}$ below sea level in the buried valley to the south

\section{Pleistocene Deposits}

\section{Jameco Gravel}

The Jameco Gravel is the oldest Pleistocene deposit in the area (fig 2E) It is considered to be a channel filling associated with an ancestral pre-Sangamon (Illınoıan?) diversion of the Hudson River (Soren, 1978, p 8) This episode of fluvial erosion probably was largely responsible for the irregular configuration of the Late Cretaceous land surface The Jameco Gravel is present in most of Kings County and southern Queens County It is thickest in the deep channels eroded into the underlying Magothy-Matawan unit and is thinnest over the higher areas For example, a small area in southeastern Queens at Far Rockaway in which the Jameco Gravel has not been found coincides with a high point on the surface of the underlying formation (fig 2D and section D-D' on pl 2) Thickness of the Jameco Gravel ranges from a feather edge at its northern limit to more than $200 \mathrm{ft}$ in the main buried valley in the center of Jamaica Bay

Jameco deposits consist mainly of a heterogeneous suite of igneous, metamorphic, and sedimentary rocks and are typically dark brown The deposits grade from coarse sand and gravel with many cobbles and some boulders in the northern part of Kings County to finer grains southward The presence of diabase fragments indicates transport by meltwater from a glacial terminus northwest of New York City Soren 


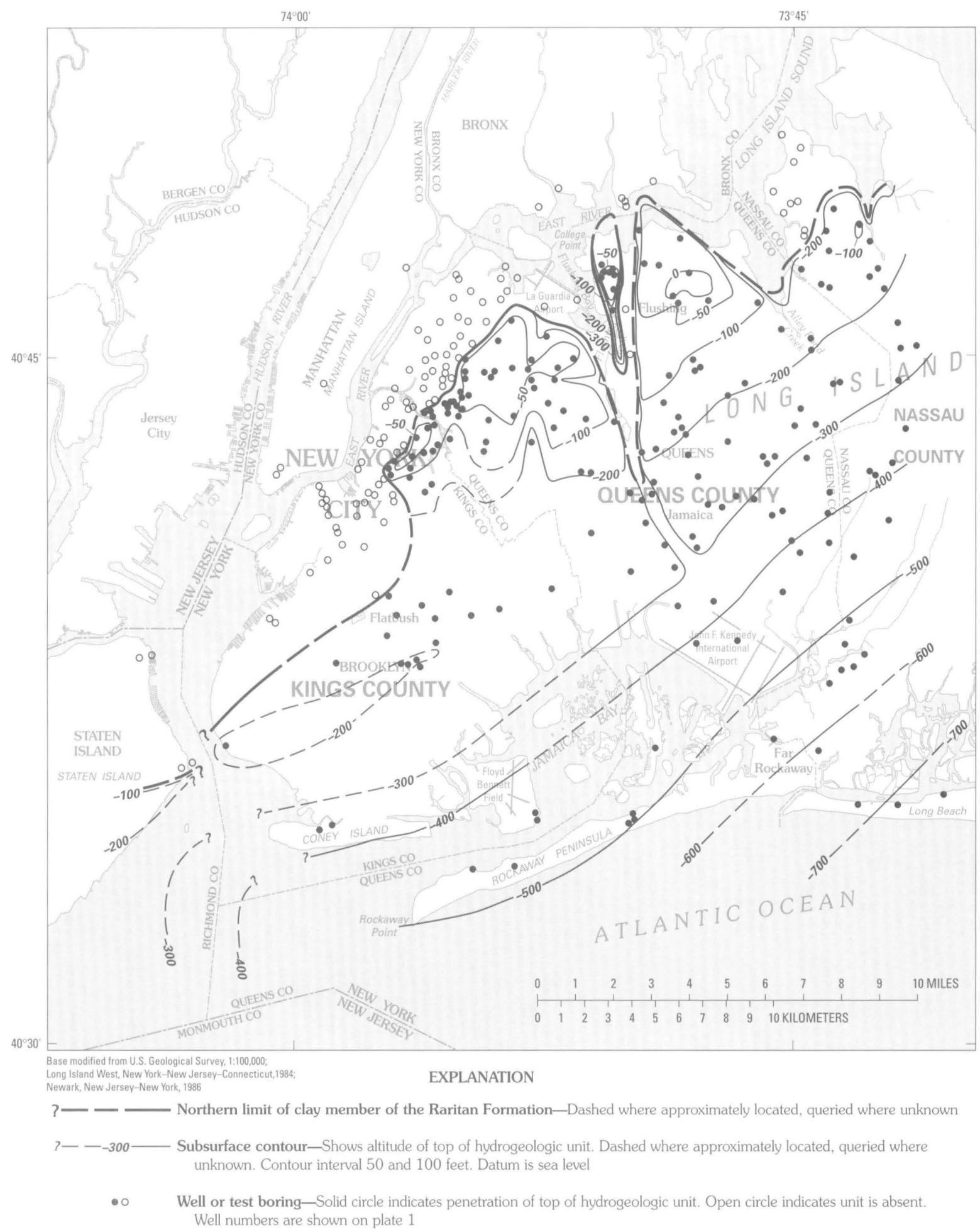

Figure $2 \mathrm{C}$. Altitude of top of clay member of the Raritan Formation.

(1978, p. 12-13) suggests that the Hudson River was diverted from its channel on the west of Manhattan Island to Queens County via the Harlem River channel and that distributary streams carried diabase fragments from there into Kings and Queens Counties.
The upper surface altitude of the Jameco Gravel is generally highest along the unit's northern edge-as little as $90 \mathrm{ft}$ below sea level in western Kings County and $80 \mathrm{ft}$ below sea level in eastern Queens County. It is generally lower to the south and over the deep ero- 


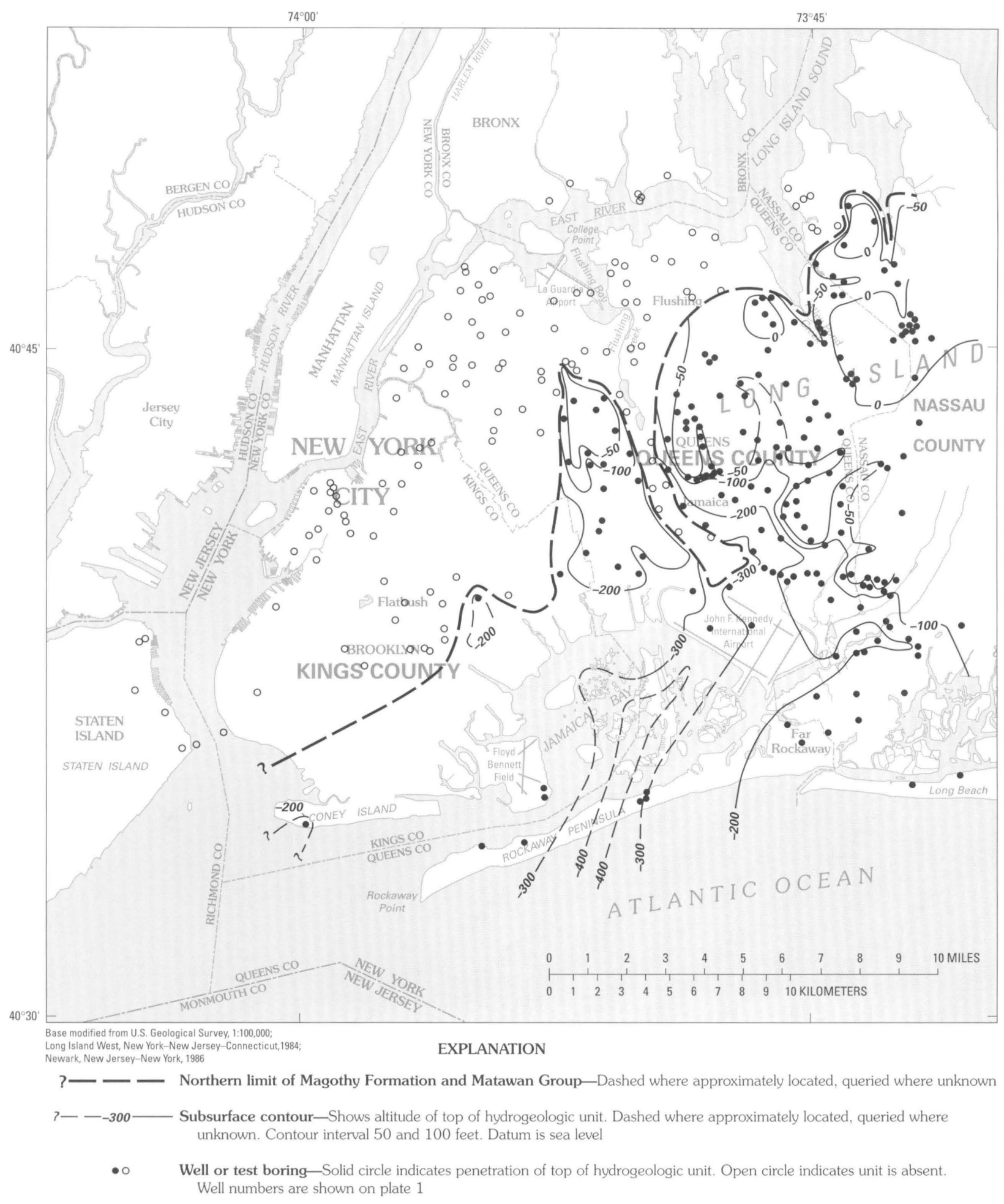

Figure 2D. Altitude of top of Magothy Formation and Matawan Group.

sional channels in the Late Cretaceous surface, where it is more than $200 \mathrm{ft}$ below sea level. The upper surface of the Jameco Gravel was probably modified by subsequent stream erosion and glaciation.

\section{Gardiners Clay}

The Gardiners Clay underlies most of Kings County and southern Queens County (fig. 2F). It unconformably overlies the Jameco Gravel and gener- 


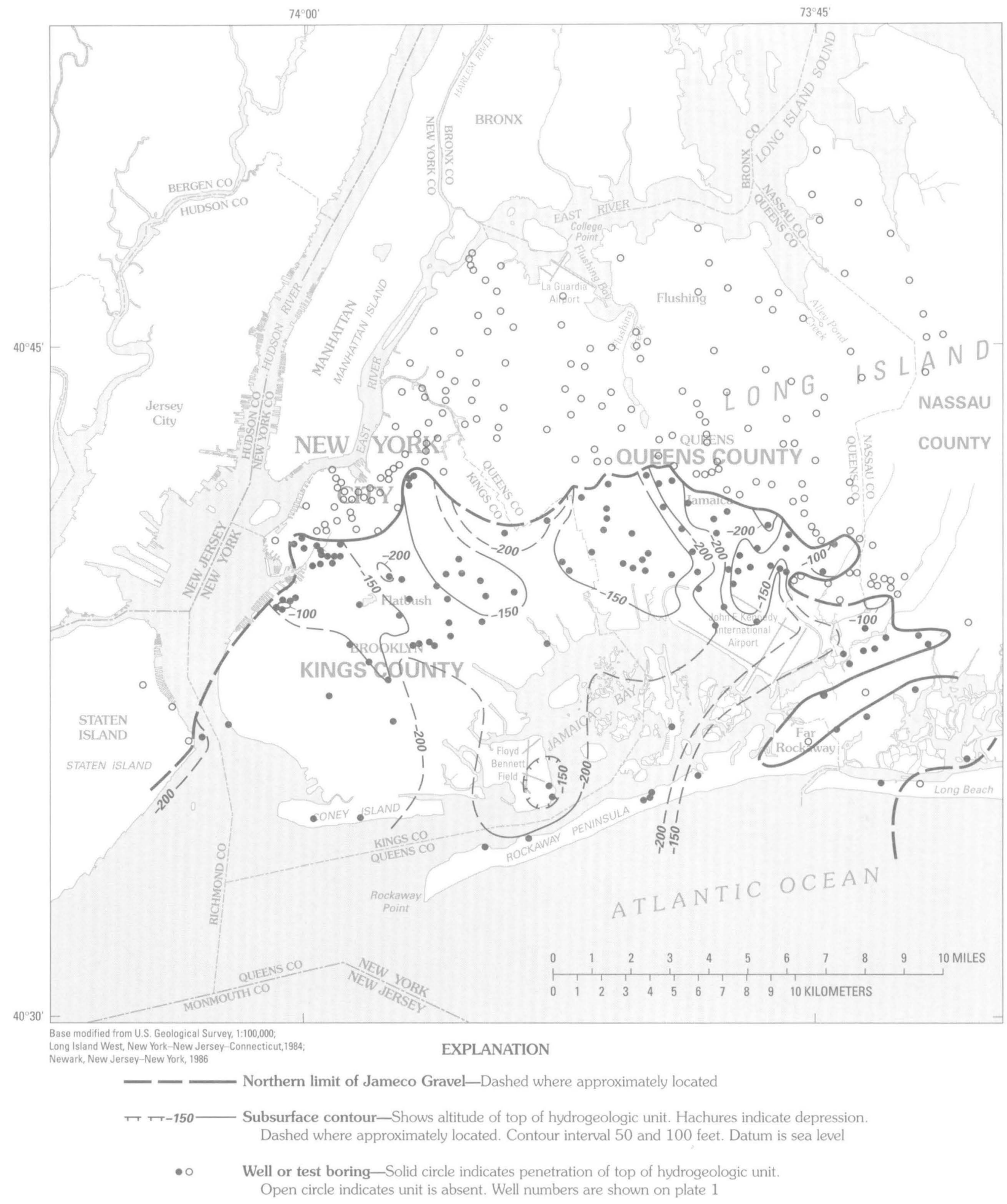

Figure 2E. Altitude of top of Jameco Gravel.

ally overlaps it along most of its extent. It consists mainly of greenish-gray clay and silt and some interbedded sand and was probably deposited in lagoonal and marine environments during an interglacial (Sangamon) interval (Soren, 1978, p. 10). The typical blue or green color of these beds is due to glauconite, chlorite, and weathered biotite. The Gardiners Clay was described as "blue clay" in many early 20 th-century drillers' logs. Fossil shells, foraminifera, and disseminated lignite are widespread in the formation. 


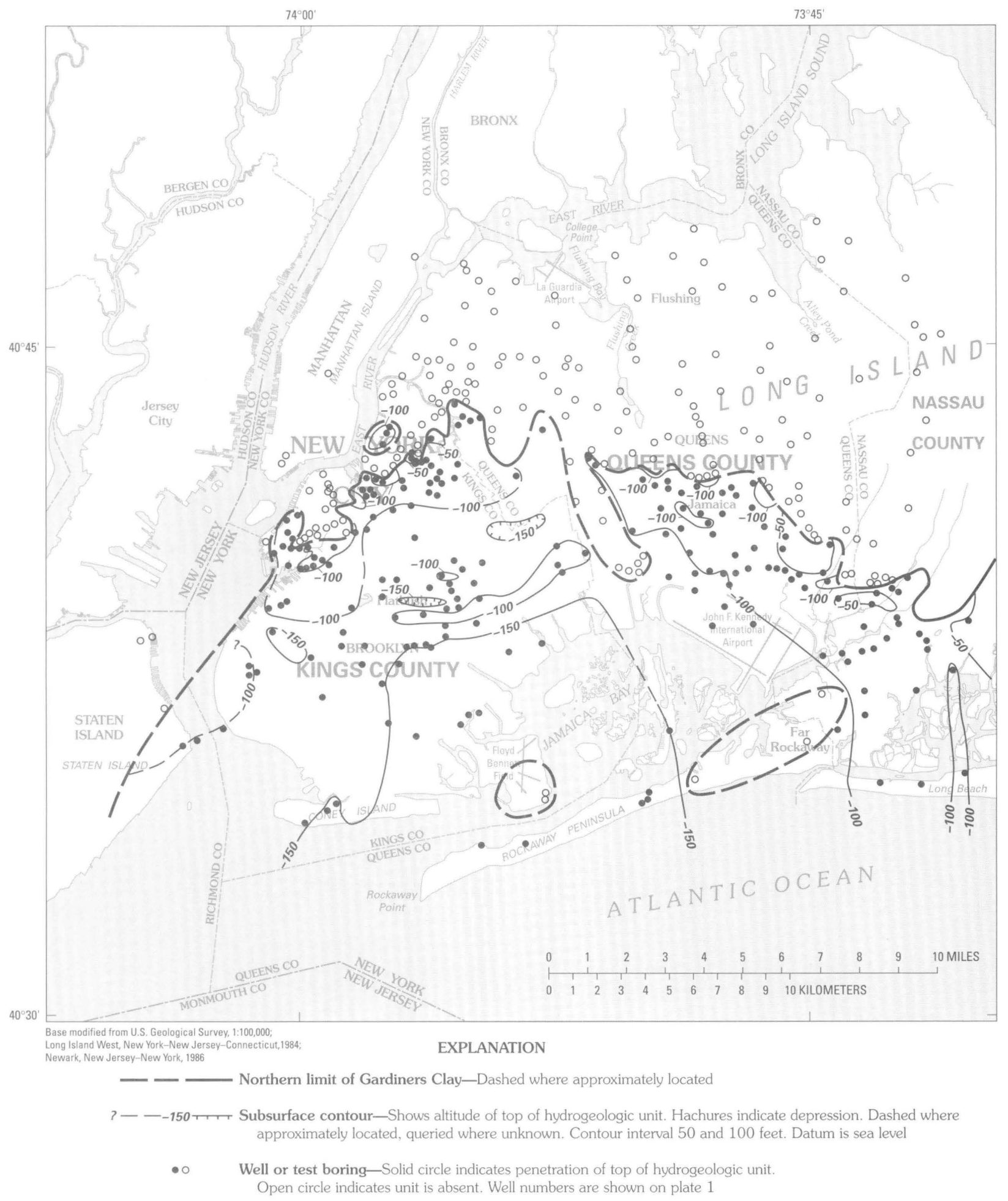

Figure 2F. Altitude of top of Gardiners Clay.

The Gardiners Clay ranges in thickness from a feather edge at its northern limit to more than $100 \mathrm{ft}$ in areas of previous erosion. The surface of the Gardiners Clay is predominantly flat but is affected locally by glacial erosion along its northern extent and by compac- tion in areas of greatest thickness. The upper surface ranges from less than $50 \mathrm{ft}$ below sea level in the north to more than $150 \mathrm{ft}$ below sea level in southern Kings County. It has not been found higher than $40 \mathrm{ft}$ below sea level anywhere on Long Island, probably because 
its deposition was controlled by a relatively constant sea level The Gardiners Clay is probably absent in two localized areas in the southern part of the area where underlying deposits (Magothy Formation and Matawan Group and Jameco Gravel) are at a higher altitude than the projected surface of the Gardıners Clay (fig 2F) One area is near Floyd Bennet field in southern Kings (section B-B', pl 2), the other is in Far Rockaway

\section{Upper Pleıstocene Deposits}

These deposits are of Wisconsin age and of glacial ongin They unconformably overlie all underlyıng units and are found at land surface in nearly all of Kings and Queens Counties The surficial geology of this area was mapped by Fuller (1914) The glacial deposits include (1) terminal moraine deposits emplaced by an ice front of Harbor Hill age (location shown in fig 4, p 15), (2) ground-moraine deposits north of the terminal moraine, and (3) glacial outwash deposits south of the terminal moraine The upper Pleistocene deposits range in thickness from zero in small areas of northwestern Queens, where bedrock crops out, to as much as $300 \mathrm{ft}$ in the terminal moraine and near the buried valleys

The terminal moraine is an unsorted and unstratified mixture of clay, sand, gravel, and boulders that were accumulated at the front of a continental glacier The ground moraine is similar to the terminal-moraine deposits but was deposited at the base of the ice sheet durıng periods of melting Meltwater from the ice front flowed southward and carried sand and gravel in broad, coalescing sheets to form an outwash plain that extends from the terminal moraine south to the coast

Pre-Harbor Hill deposits are present at depth in the sequence of upper Pleistocene deposits (table 1) The " 20 -foot" clay in eastern Queens and Nassau Counties is a marine clay deposited during the Ronkonkoma-Harbor Hill interstade (Soren, 1978, p 11) This unit locally separates the Harbor Hill Drift from the underlyıng Ronkonkoma Drift and earlıer deposits

\section{Water-Transmitting Properties}

The six major geologic units described in the preceding section generally correspond to hydrologic units with specific water-bearing characteristics These hydrologic units and their corresponding geologic names (table 1) are, in ascending order, the Lloyd aqui- fer (Lloyd Sand Member of the Rarıtan Formation), the Raritan confining unit (the clay member of the Raritan Formation), the Magothy aquifer (Magothy Formation and Matawan Group, undifferentiated), the Jameco aquifer (Jameco Gravel), the Gardıners Clay (Gardıners Clay), and the upper glacial aquifer (upper Plesstocene deposits)

The aquifers are areally extensive unconsolıdated formations that yield significant quantities of water to wells The most permeable units are the beds of predominantly sand or sand and gravel The two clayey formatıons (the Gardıners Clay and Raritan confinıng unit) are significant confinıng units and have been estımated to have a vertical hydraulic conductıv1ty of $0001 \mathrm{ft} / \mathrm{d}$ (Franke and Cohen, 1972), several orders of magnitude lower than that of the aquifers Where present, they separate the ground-water reservoir into three major aquifer units-the Lloyd, the Jameco-Magothy, and the upper glacial aquifers (pl 2) The Gardıners Clay restricts vertical flow between the upper glacial and Jameco-Magothy aquifers, and the Raritan confining unit restricts vertical flow between the Jameco-Magothy and Lloyd aquifers Where these confining units are absent, ground-water flow between aquifer units is uninhibited The extent of the confining units is critical in defining the distribution of hydraulic head and ground-water flow patterns

The bedrock underlyıng the unconsolidated deposits has a low hydraulic conductivity and does not yield more than a few gallons per minute to wells The quantity of water that can flow across this boundary is insignificant compared with the quantities that flow in the overlying unconsolidated units Therefore, the bedrock surface is considered to be the bottom boundary of the ground-water flow system

\section{Lloyd Aquifer}

The Lloyd aquifer has moderate horizontal hydraulic conductivity, which McClymonds and Franke (1972) estımated to range from 50 to $70 \mathrm{ft} / \mathrm{d}$, although individual sandy and gravelly beds within the aquifer could have much higher values High-capacity wells that tap the Lloyd aquifer generally have been pumped at rates less than $1,000 \mathrm{gal} / \mathrm{mın}$, but pumpage as high as $1,600 \mathrm{gal} / \mathrm{min}$ from a single well has been reported (Soren, 1971, p 11) Specific capacities of wells screened in the Lloyd aquifer, in gallons per minute pumped per foot of drawdown in the well, (gal/ $\mathrm{min}) / \mathrm{ft}$, range from 4 to about $40(\mathrm{gal} / \mathrm{min}) / \mathrm{ft}$ (Soren, 1971, p 11) The Lloyd aquifer is confined between 
the bedrock and the Raritan confining unit but is in good hydraulic connection with the overlying aquifers where the confinıng unit has been eroded (fig 2B)

\section{Jameco-Magothy Aquifer}

Although the Magothy and Jameco deposits differ in origin, lithologic character, and water-transmitting properties, they are considered as one aquifer unit in this report and are referred to as the Jameco-Magothy aquifer The Jameco Gravel was deposited in deep channels incised in the Magothy aquifer and provides good hydraulic connection between these units as shown in plate 2 (sections A-A', B-B', D-D', and E-E') In addition, these deposits are hydraulically separated from the underlying Lloyd aquifer by the Raritan confining unit and from the overlying upper glacial aquifer by the Gardiners Clay The lateral hydraulic contınuity between the Jameco and Magothy aquifers enables both to act as a single aquifer in which the Jameco is merely a zone of higher hydraulic conductivity

The hydraulic conductivity of the Magothy aquifer has been estımated to range from 60 to $90 \mathrm{ft} / \mathrm{d}$ (McClymonds and Franke, 1972), but, as in the Lloyd aquifer, individual sandy and gravelly beds could have values several times higher No pumping of the Magothy aquifer in Kings County is known, but wells that tap the Magothy in Queens County have yielded as much as $1,500 \mathrm{gal} / \mathrm{min}$ The specific capacities of wells tested have ranged from 15 to 30 (gal/min)/ft in fine sand to $50(\mathrm{gal} / \mathrm{min}) / \mathrm{ft}$ in coarser material (Soren, 1971, p 10)

Soren (1971, p 9) estımated the horızontal hydraulic conductivity of the Jameco aquifer to be at least $270 \mathrm{ft} / \mathrm{d}$ Wells tapping the Jameco have yielded $1,600 \mathrm{gal} / \mathrm{min}$, and specific capacities of wells in the Jameco as high as $180(\mathrm{gal} / \mathrm{min}) / \mathrm{ft}$ have been reported (Soren, 1971, p 9) Although the Jameco aquifer is considerably thınner than the Magothy, their transmıssivities are comparable

The Jameco-Magothy aquifer system is confined in southern Queens and in Kings County wherever it lies between the Gardiners Clay and the Raritan confining unit (pl 2 and fig 2F) In northern Queens, however, the Magothy attains altitudes above sea level and is in good hydraulic connection with the water-table aquifer Lenses and beds of clay and silty clay whose overlapping arrangement produces an anisotropy of perhaps as high as 1001 tend to cause a confinıng effect with depth

\section{Upper Glacial Aquifer}

The upper glacial aquifer consists of saturated glacial drift Sand and gravel beds deposited as outwash south of the terminal moraine are highly permeable and are capable of yielding large quantities of water Horizontal hydraulic conductıvity of glacial outwash has been estımated to be $270 \mathrm{ft} / \mathrm{d}$ (Franke and Cohen, 1972), honzontal hydraulic conductıvity of moraine deposits on the north shore, which include considerable clay and silt and are poorly sorted, is probably less than half that value Public-supply and other high-capacity wells that tap outwash deposits have commonly yielded as much as $1,500 \mathrm{gal} / \mathrm{min}$ and have specific capacities ranging from 50 to 60 (gal/ $\mathrm{min}$ )/ft (Soren, 1971, p 8) Scattered coarse sand and gravel lenses within the morainal deposits have the potential for yielding significant amounts of water, but their locations can not be predicted

Water in the upper glacial aquifer is under watertable (unconfined) conditions but probably is confined locally between beds of clay and silt within the morainal deposits Such clayey and silty beds, where near the water table, impede ground-water recharge and thus locally cause unusually high water levels and temporary ponding that is often confused with perched conditions

\section{PREDEVELOPMENT HYDROLOGIC CONDITIONS}

The only natural source of freshwater recharge to the Long Island ground-water system is precipitation, which replenishes the large volume of fresh water stored in the unconsolidated deposits The groundwater system is bounded on top by the water table, on the bottom by bedrock, and on the sides by salıne ground water or surface-water bodies (fig 3 ) The ground water is in continuous motion from the water table to its point of discharge The path of flow is three dimensional and is affected by the geometry and hydraulic characteristics of the aquifers and confining units, and by the proximity and nature of discharge boundaries

Much of the water that enters the ground-water system remains in the upper glacial aquifer, where it moves laterally and discharges to streams or the surrounding saltwater bodies (fig 3) ground-water seepage to streams results in shallow ground-water circulation patterns or flow subsystems (Franke and 
Cohen, 1972). (These shallow flow systems are not shown in fig. 3.)

The rest of the water that enters the system flows downward to the Jameco-Magothy aquifer (fig. 3), and some flows still deeper to the Lloyd aquifer. This downward movement of water is greater in areas of continuity between aquifer units than in areas of confining units, where it moves much more slowly and is refracted to near vertical through the confining units. All ground water eventually moves seaward. Near the shore, downward gradients reverse, and water moves upward into shallower aquifers. The seaward extent of fresh ground water in the confined aquifers is the interface between fresh and saline ground water. Water generally flows upward along this interface. Saline water has a greater density than freshwater; at large scales, the two fluids behave largely as though immiscible. Although a zone of diffusion forms at the interface, mixing is minimal under nonpumping conditions, and flow across the interface is virtually nil. Water from the confined aquifers flows upward through the Raritan confining unit or Gardiners Clay and mixes with overlying saline ground water and thus is lost from the freshwater system.

\section{Water-Table Configuration}

The configuration of the water table indicates the horizontal pattern of ground-water movement and the amount of freshwater stored in the ground-water reservoir. The first map of the water-table configuration on Long Island, made in 1903 (fig. 4), provides the best available estimate of the predevelopment water-table configuration, although urbanization and development of the ground-water system even then had begun to affect water levels.

The water table in 1903 had a steep gradient westward into Queens County (fig. 4), which indicates that a significant quantity of ground water entered Queens County from the east and helped maintain water levels in both Kings and Queens Counties. The water table reached an altitude of over $50 \mathrm{ft}$ at the Queens-Nassau County line (fig. 4) and, in central Nassau County, attained a maximum altitude of over $90 \mathrm{ft}$ (Veatch and others, 1906).

Long Island's major ground-water divide trends east-west through northern Queens County, then gradually southward through Kings County (fig. 4). The asymmetry of the water table from north to south, with steep northward gradients and flatter southward gradi-

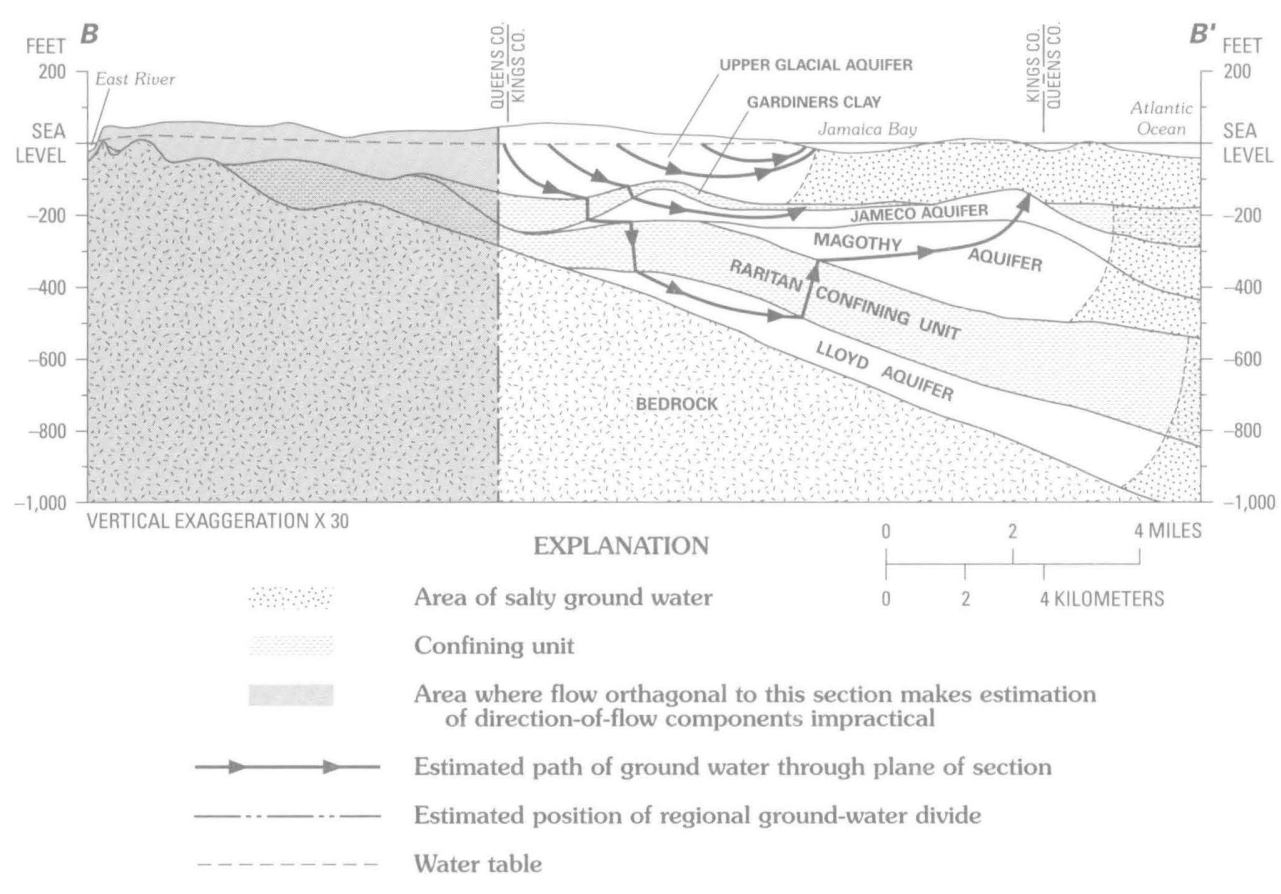

Figure 3. Estimated flow patterns along section $B-B^{\prime}$ under predevelopment conditions. (Location is shown in fig. 4.) 
ents (fig. 4), has three causes: (1) the thickening of the aquifers southward, (2) higher hydraulic conductivity in the outwash plain south of the divide than in moraine deposits north of it, and (3) more ground-water seepage to south-shore streams than to north-shore streams.
These characteristics also are observed in the present water-table configuration.

The ground-water levels of 1903 indicate steep ground-water gradients toward several stream channels in Kings and Queens Counties. Flow in these channels,

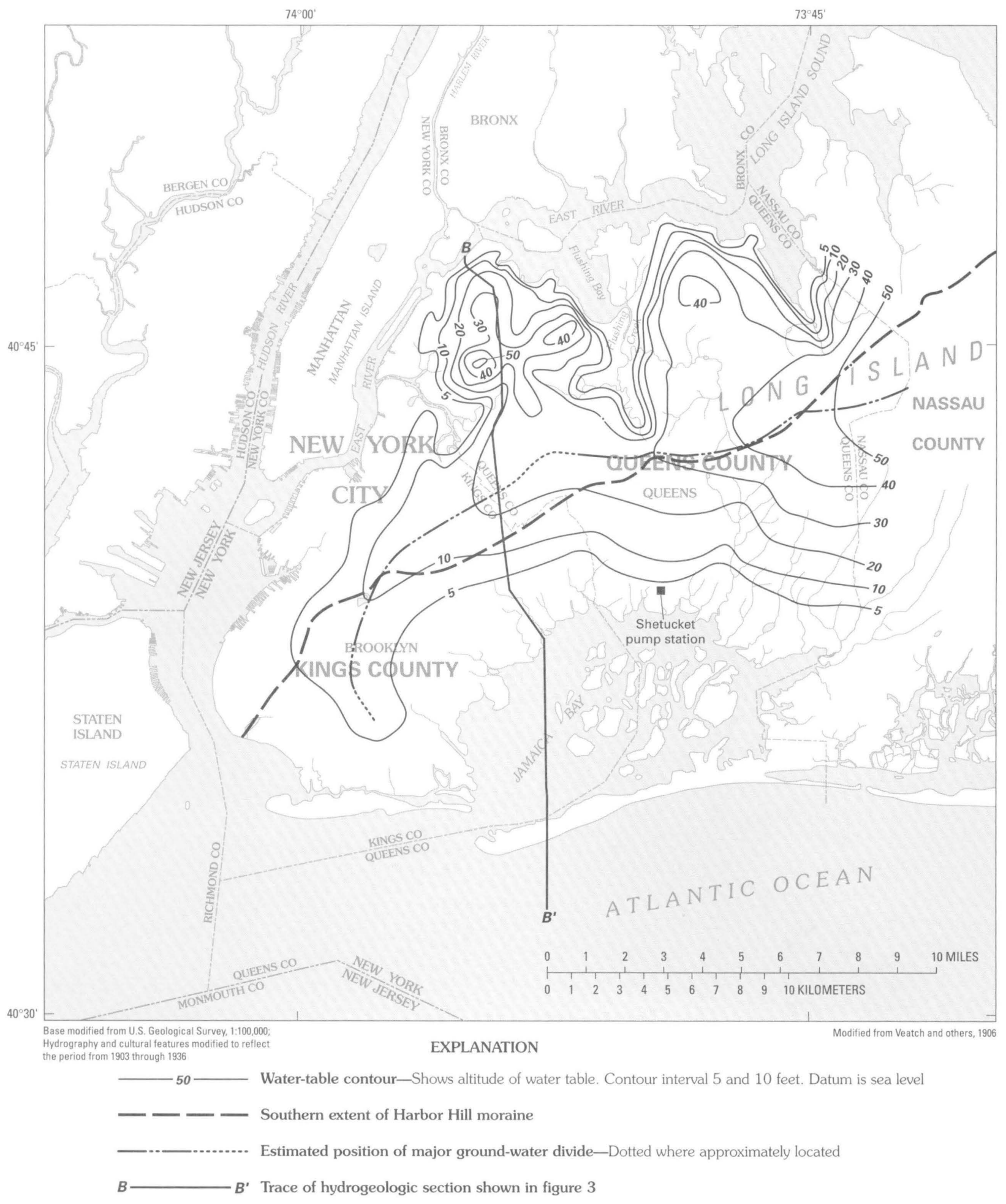

Figure 4. Water table in 1903 . Section $B-B^{\prime}$ is depicted in figure 3. 
which are relict from the glacial period, was sustained primarily by ground-water seepage The presence of many stream channels and swampy areas in southern Kıngs and Queens Counties suggests that a signıficant quantity of ground water discharged to surface-water bodies in this area

Areas of anomalously high water levels are ev1dent on the north shore of Queens County (fig 4) These are caused by the high altitude of the bedrock surface (fig 2A) in this area and by zones of low hydraulic conductivity in the moraine deposits, which restrict ground-water discharge to Long Island Sound Similarly high water levels are associated with moraine deposits farther east on Long Island

\section{Water Budget}

Before development, the Long Island groundwater system was in a state of dynamıc equilibrium Although the system fluctuates in response to natural variations in precipitation, an average predevelopment hydrologic condition can be estımated Under predevelopment conditions, water entered the part of the Long Island ground-water system that underlies Kings and Queens Counties as recharge from precipitation and, to a lesser degree, as ground-water inflow from Nassau County Water discharged by seepage to streams and to the surrounding saline ground-water and surface-water bodies The quantities of these inflows and outflows under predevelopment (equilibrium) conditions are presented in table 2 The estımates given in table 2 were obtained through evaluation of hydrologic records in conjunction with results of flow-model analysis of the entire Long Island ground-water system This model is being developed in a concurrent study by the U S Geological Survey (H T Buxton and D A Smolensky, U S Geological Survey, written commun, 1988), and much of the hydrogeologic information presented here was used in model construction

Hydrologic data from central and eastern Long Island indicate that, under predevelopment conditions, about 50 percent of the annual precipitation infiltrated to the water table and recharged the ground-water system (Franke and McClymonds, 1972), the remainder was lost through evapotranspiration and direct (overland) runoff Precipitation on Long Island ranges from 42 to 47 inches per year and averages 44 inches (Miller and Frederick, 1972) About 21 inches is estımated to have been lost through evapotranspiration, and only 1 inch lost as direct runoff
About $396 \mathrm{Mgal} / \mathrm{d}$ of precipitation fell on the $189-\mathrm{mi}^{2}$ area of Kıngs and Queens Counties durıng

Table 2 Predevelopment ground-water budget

[Values are in million gallons per day]

\begin{tabular}{lr}
\multicolumn{2}{c}{ Inflow } \\
Recharge from precipitation & 209 \\
Ground-water inflow from Nassau County & 6 \\
Total & 215 \\
& \\
& \\
Base flow to streams & Outflow \\
Subsea discharge & 62 \\
$\quad$ Total & 153 \\
\hline
\end{tabular}

predevelopment conditions Of this total, $209 \mathrm{Mgal} / \mathrm{d}$ is estımated to have become recharge (table 2), this equals an average recharge rate of $11(\mathrm{Mgal} / \mathrm{d}) / \mathrm{mi}^{2}(82$ $\mathrm{Mgal} / \mathrm{d}$ over the $76 \mathrm{mi}^{2}$ of Kungs County and $127 \mathrm{Mgal} /$ $\mathrm{d}$ over the $113 \mathrm{mi}^{2}$ of Queens County) The remaining inflow to western Long Island (from Nassau County) is estımated to have been $6 \mathrm{Mgal} / \mathrm{d}$ Therefore, the total inflow to the ground-water reservoir beneath Kıngs and Queens Counties under predevelopment conditions was $215 \mathrm{Mgal} / \mathrm{d}$

An equal rate of ground-water discharge to streams (base flow) and to salıne ground-water bodies (subsea discharge) balances this inflow Before 1900, about 15 streams flowed in Kings and Queens Counties, the base flow of which is estimated to have been between 90 and 95 percent of their total flow An examınation of streamflow measurements made around the turn of the century (Veatch, 1906, Burr, Hering, and Freeman, 1904, and Spear, 1912), ınd1cated that about $62 \mathrm{Mgal} / \mathrm{d}$ discharged from the ground-water system to streams as base flow-almost 30 percent of the water budget of the area Thus, the remainıng $153 \mathrm{Mgal} / \mathrm{d}$ discharged as subsea discharge, as explained in the previous section and shown in figure 3

\section{Ground-Water Quality}

Little if any information on ground-water quality in western Long Island under predevelopment cond1tions is available The chemical composition of water samples taken from wells in eastern Long Island during 1932-65 is summarized in table 3 The eastern part of the island generally is similar to Kings and Queens 
geologically and climatically but was not urbanized unt1l much later These data, therefore, are the most reliable indication of pre-development ground-water quality in the western part of Long Island

The Jameco Gravel, which underlies only western Long Island, could affect the ground-water quality there, however, because it contains abundant ferromagnesium minerals, but no data are avallable to indicate its effect on water quality under predevelopment cond1tions Elsewhere the aquifers consist primarily of quartz and, except for the dissolution of silica, are relatively unreactive Much of the dissolved-solids content of Long Island's ground water under predevelopment conditions was derived from constituents dissolved in precipitation (table 3) Pearson and Fisher (1971) suggest a method of estımatıng chemical concentrations in water that recharges the groundwater system-the concentration in precipitation is multiplied by a specific factor to account for the effects of evapotranspiration Given that about half of the precipitation on Long Island is lost through evapotranspiration (Franke and McClymonds, 1972, p 19), a factor of 2 would be used This method can be used throughout the following discussion to indicate what proportion of a conservative constituent was introduced in recharge water

As water passes through the soll zone and moves through the aquifer, it undergoes reactions that modify its chemical character The following paragraphs briefly describe the major inorganic constituents of Long Island's ground water

\section{Nitrate}

Nitrate is the only major constituent found in lower concentrations in ground water than in precipitation (table 3) Nitrogen in the form of nitrate is an essential nutrient for most plants When water from precipitation enters the soil zone, it is absorbed by roots and converted to organic nitrogen (nucleic acids and proteıns) As a result, ground water contains less nitrogen than does precipitation (table 3) Kimmel (1972, p D200) surveyed the avallable data on nitrate in ground water on eastern Long Island and concluded that the nitrate concentration of water in the upper glacial aquifer under predevelopment conditions was $02 \mathrm{mg} / \mathrm{L}$ The nitrate analyses shown in table 3 suggest that the predevelopment levels of nitrate could have been even lower

\section{Silica}

Silica $\left(\mathrm{S}_{1} \mathrm{O}_{2}\right)$ is the most abundant dissolved constituent of ground water under predevelopment cond1tions Little if any silica enters the ground with recharge from precipitation (Hem, 1970, p 48-50) Silica is taken into solution during the chemical decomposition of silicate minerals, such as quartz, feldspars, and amphiboles Silica concentrations are about equal to the solubility of quartz $\left(6 \mathrm{mg} / \mathrm{L}\right.$ at $\left.25^{\circ} \mathrm{C}\right)$, the most common mineral in Long Island aquifers Silica concentrations listed in table 3 range from 59 to $10 \mathrm{mg} / \mathrm{L}$ The silica in pristine ground water makes up 20 to 33 percent (by weight) of the total dissolved-solids content

Iron

Iron concentrations of pristine ground water range from 001 to $32 \mathrm{mg} / \mathrm{L}$ Only 4 of 22 analyses given in table 3 show iron concentrations above 075 $\mathrm{mg} / \mathrm{L}$, and all samples were from the Magothy and Lloyd aquifers The dissolution of iron-bearing minerals, such as pyrite $\left(\mathrm{FeS}_{2}\right)$ and ferromagnesium silicates, is the most likely source of iron Iron occurs in the upper glacial aquifer where dissolved oxygen is present Under these oxidizing conditions, the ironbearıng minerals are generally stable because the iron 1s already in the ferric $\left(\mathrm{Fe}^{+3}\right)$ oxidation state (Vecchiol and others, 1974) In the deeper aquifers, where dissolved oxygen is lackıng, reducıng conditions cause the iron-bearing minerals to decompose, releasing ferrous iron $\left(\mathrm{Fe}^{+2}\right)$ into the ground water Iron in ground water generally is in the ferrous state (Hem, 1970) Ground water in western Long Island could be affected by contact with the iron-bearıng Jameco Gravel

\section{Sulfate}

Concentrations of sulfate in the upper glacial aquifer range from 26 to $12 \mathrm{mg} / \mathrm{L}$, those in five of six analyses were $8 \mathrm{mg} / \mathrm{L}$ or less In shallow ground water, where dissolved oxygen is high, additional sulfate can be introduced by oxidation of pyrite and marcasite deposits Sulfate concentrations in precipitation are about $4 \mathrm{mg} / \mathrm{L}$ (table 3 ) and, when concentrated by evapotranspiration, can account for most sulfate in solution

As ground water moves downward along natural flow paths and enters a reducing environment, bacteria and organic matter can decrease sulfate concentrations through reactions that produce hydrogen sulfide and bicarbonate (Hem, 1970, p 170) Sulfate concentra- 
Table 3 Chemical composition of Long Island ground water and precipitation under predevelopment conditions

[Data from U S Geological Survey records, mg/L, milligrams per liter, - , no analysıs avallable, $n$ a , not applicable, ND, not detectable, methods of analysis and detection limits vary]

\begin{tabular}{|c|c|c|c|c|c|c|c|c|c|c|c|c|c|c|}
\hline $\begin{array}{l}\text { Source of } \\
\text { sample }\end{array}$ & $\begin{array}{c}\text { Date of } \\
\text { sample } \\
\text { collection }\end{array}$ & $\begin{array}{c}\text { Silica, } \\
\text { dissolved } \\
(\mathrm{mg} / \mathrm{L} \text { as } \\
\left.\mathrm{SiO}_{2}\right)\end{array}$ & $\begin{array}{l}\text { Iron } \\
(\mathrm{mg} / \mathrm{L} \text { as } \\
\mathrm{Fe})\end{array}$ & $\begin{array}{l}\text { Calcium, } \\
\text { dissolved } \\
\text { (mg/L as } \\
\text { Ca) }\end{array}$ & $\begin{array}{c}\text { Magnesium, } \\
\text { dissolved } \\
\text { (mg/L as } \\
\mathrm{Mg})\end{array}$ & $\begin{array}{c}\text { Hardness, } \\
\text { (mg/L as } \\
\mathrm{CaCO}_{3} \text { ) }\end{array}$ & $\begin{array}{c}\text { Sodium, } \\
\text { dissolved } \\
\text { (mg/L as } \\
\mathrm{Na})\end{array}$ & $\begin{array}{l}\text { Potassium } \\
\text { dissolved } \\
\text { (mg/L as } \\
\text { K) }\end{array}$ & $\begin{array}{c}\text { Bicar- } \\
\text { bonate } \\
\text { (mg/L as } \\
\left.\mathrm{HCO}_{3}\right)\end{array}$ & $\begin{array}{c}\text { Sulfate, } \\
\text { dissolved } \\
\text { (mg/L as } \\
\left.\mathrm{SO}_{4}\right)\end{array}$ & $\begin{array}{l}\text { Chloride, } \\
\text { dissolved } \\
\text { (mg/L as } \\
\text { Cl) }\end{array}$ & $\begin{array}{l}\text { Nitrate, } \\
\text { dissolved } \\
\text { (mg/L as } \\
\mathrm{NO}_{3} \text { ) }\end{array}$ & $\begin{array}{c}\text { Total } \\
\text { dissolved } \\
\text { solıds } \\
\text { (mg/L) }\end{array}$ & $\underset{\text { (units) }}{\mathrm{pH}}$ \\
\hline \multicolumn{15}{|c|}{ PRECIPITATION } \\
\hline${ }^{1}$ Station $A$ & $\begin{array}{l}\text { A } 11 / 65 \text { to } \\
3 / 66\end{array}$ & - & - & 05 & 03 & 25 & 16 & 01 & - & 38 & 27 & 08 & 10 & 45 \\
\hline${ }^{2}$ Station $\mathrm{B}$ & $\begin{array}{c}\text { B } 8 / 31 / 65 t \\
9 / 30 / 65\end{array}$ & to - & - & 3 & 4 & 24 & 15 & 2 & - & 4 & 22 & 4 & - & - \\
\hline \multicolumn{15}{|c|}{$\begin{array}{l}\text { GROUND WATER } \\
\text { Upper glacial aquifer }\end{array}$} \\
\hline S 3197 & $4 / 16 / 48$ & 91 & 037 & 16 & 12 & - & 39 & 5 & 8 & 4 & 4 & 2 & 28 & 63 \\
\hline S 5518 & $10 / 15 / 48$ & 6 & 01 & 15 & 13 & 91 & 32 & 6 & 4 & 6 & 5 & 1 & 26 & 65 \\
\hline S 6405 & $12 / 17 / 48$ & 59 & 19 & 21 & 16 & 118 & 47 & 9 & 1 & 12 & 6 & 1 & 36 & 55 \\
\hline S 6432 & $12 / 17 / 48$ & 96 & 75 & 21 & 11 & 98 & 38 & 4 & 11 & 26 & 44 & 1 & 29 & 67 \\
\hline S 9141 & $2 / 13 / 50$ & 61 & 41 & 13 & 13 & 86 & 54 & 11 & 10 & 66 & 59 & 1 & 32 & 69 \\
\hline S 9142 & $2 / 13 / 50$ & 6 & 23 & 14 & 2 & 117 & 55 & 14 & 8 & 8 & 69 & 2 & 34 & 65 \\
\hline \multicolumn{15}{|c|}{ Magothy aquifer } \\
\hline${ }^{3} \mathrm{~N} 2790$ & $\mathrm{n} \mathrm{a}$ & 74 & 6 & 34 & 17 & 15 & 37 & 60 & 60 & 41 & 375 & ND & 23 & 56 \\
\hline N 3866 & $10 / 14 / 52$ & 98 & 29 & 13 & 4 & 5 & 39 & 5 & 60 & 50 & 35 & 31 & 28 & 60 \\
\hline N 4149 & $9 / 30 / 53$ & 65 & 61 & 5 & 1 & 20 & 24 & 3 & 26 & 16 & 25 & 1 & 15 & 58 \\
\hline${ }^{3} \mathrm{~N} 7787$ & $\mathrm{na}$ & 75 & 18 & 108 & 24 & 37 & 39 & 68 & 75 & 40 & 378 & ND & 24 & 558 \\
\hline${ }^{3} \mathrm{~N} 7889$ & $\mathrm{n} \mathrm{a}$ & 75 & 25 & 39 & 30 & 22 & 40 & 50 & 50 & 39 & 375 & ND & 23 & 525 \\
\hline $\mathrm{S} \quad 12$ & $5 / 2 / 33$ & - & - & 10 & - & 4 & - & - & 10 & 20 & 70 & ND & - & - \\
\hline S 40 & $10 / 26 / 32$ & - & 38 & 10 & - & $<5$ & - & - & 22 & 10 & 40 & 04 & - & - \\
\hline S $\quad 51$ & $10 / 10 / 32$ & - & 13 & 20 & - & 10 & - & - & 20 & 10 & 68 & 04 & - & - \\
\hline$S 24769$ & $7 / 7 / 65$ & 59 & 31 & 14 & 6 & 6 & 37 & 6 & 9 & 32 & 40 & ND & 24 & 62 \\
\hline $\mathrm{S} 24770$ & $8 / 10 / 65$ & 64 & 14 & 21 & 2 & 6 & 30 & 3 & 8 & 20 & 35 & 1 & 16 & 62 \\
\hline \multicolumn{15}{|c|}{ Lloyd aquifer } \\
\hline N 67 & $8 / 2 / 62$ & 82 & 32 & 9 & 8 & 60 & 32 & 4 & 20 & 65 & 42 & ND & 25 & 51 \\
\hline N 1618 & $4 / 30 / 57$ & 75 & 14 & 26 & 14 & 12 & 29 & 7 & 12 & 50 & 38 & ND & 30 & 600 \\
\hline N 2602 & $5 / 26 / 57$ & 83 & - & 11 & 6 & 5 & 28 & 7 & 8 & 8 & 38 & 09 & 22 & 610 \\
\hline N 3355 & $6 / 25 / 51$ & 92 & ND & 22 & 8 & 9 & 38 & 6 & 13 & 8 & 45 & ND & 28 & 680 \\
\hline N 3448 & $7 / 31 / 62$ & 90 & - & 18 & 27 & 160 & 89 & 12 & ND & 20 & 82 & ND & 52 & 45 \\
\hline N 3687 & $1 / 16 / 52$ & 10 & 37 & - & - & 8 & 76 & ND & 1 & 16 & 50 & ND & - & 480 \\
\hline N 4405 & $9 / 15 / 54$ & 82 & - & 20 & 7 & 8 & - & - & 6 & 15 & 10 & 09 & 53 & 680 \\
\hline N 5227 & $11 / 14 / 61$ & - & 15 & 9 & 5 & 43 & 62 & 5 & 4 & 14 & 2 & 1 & 36 & 53 \\
\hline S 6409 & $11 / 8 / 48$ & 75 & 13 & 15 & 16 & 103 & 44 & 22 & 16 & 35 & 41 & 1 & 32 & 64 \\
\hline S 6434 & $6 / 2 / 49$ & 84 & 47 & 43 & 27 & 219 & 72 & 24 & 24 & 12 & 56 & 1 & 53 & 65 \\
\hline
\end{tabular}

${ }^{1}$ Average of six composite monthly samples from gage near Brookhaven Natıonal Laboratory, October 1965 through March 1966 From Franke and McClymonds (1972, p 36 )

${ }^{2}$ Composite of 102 inches of precipitation collected from gage at Upton, N Y Analyses by U S Geological Survey Data from U S Geological Survey (1965)

${ }^{3}$ From Vecchiolı and others (1974, p C25) 
tions in both the Magothy and Lloyd aquifers vary locally (table 3 ), ranging from 10 to $20 \mathrm{mg} / \mathrm{L}$ in the Magothy aquifer and from 08 to $20 \mathrm{mg} / \mathrm{L}$ in the Lloyd aquifer These variations can be attributed to local variation in abundance of (1) bacteria, and (2) an organic food supply required for sulfate reduction Several analyses show high bicarbonate concentrations in assocration with low sulfate concentration, this may ind1cate sulfate reduction These variations also could result from local differences in the avallability of pyrite as a source, or from the presence of water that entered the ground-water system before the mid-19th century, when sulfate concentrations in precipitation were lower than $4 \mathrm{mg} / \mathrm{L}$ Average sulfate concentrations appear to be higher in the Lloyd than in the Magothy, but this cannot be explained

\section{Hardness}

Water hardness is due to the presence of calcium and magnesium ions Calcium and magnesium are present in several of the silicate minerals, such as feldspar (plagioclase), amphiboles, and pyroxenes, which are prevalent throughout the upper glacial aquifer (DeLaguna, 1964) The dissolution of these minerals is the most likely source of hardness in the ground water The data in table 3 indicate that the hardness of ground water is extremely low, ranging from 15 to $219 \mathrm{mg} / \mathrm{L}$ as $\mathrm{CaCO}_{3}$ Natural hardness on western Long Island could be higher than farther east because the Jameco aquifer contains abundant ferromagnesium minerals Soren (1971) states that uncontaminated ground water in Queens contains less than $60 \mathrm{mg} / \mathrm{L}$ of hardness.

\section{Sodium}

Sodium in ground water is derived from two sources-airborne salt from the sea, and aquifer materials Salt spray from the ocean is blown landward, then carried to the water table with infiltratıng precipitation The sodium concentration of precipitation is about $15 \mathrm{mg} / \mathrm{L}$, which then increases through evaporation before it reaches the ground-water system The rest of the sodium in the ground water is derived from the dissolution of minerals such as sodic feldspars in the soil zone and aquifer DeLaguna (1964) concludes that the sodium in natural ground water on Long Island is probably derived in about equal amounts from sea salt in precipitation and the dissolution of minerals

\section{Chloride}

The source of practically all chloride in Long Island's ground water under predevelopment cond1tions was salt spray picked up by the wind and introduced into the ground-water system through infiltration of precipitation (Franke and McClymonds, 1972)

Jackson (1905, p 29-31) estımates that the predevelopment concentrations of chloride in water on Long Island ranged from 3 to $8 \mathrm{mg} / \mathrm{L}$ This agrees with concentrations shown in table 3 for the eastern part of Long Island Lusczynskı and Swarzenskı (1966, p 19) assumed that, before development, ground water on Long Island contained less than $10 \mathrm{mg} / \mathrm{L}$ chloride Chloride contamination was evident by the turn of this century in Kings and Queens Counties, where contamination from land surface began long before 1900 During 1898-1902, average chloride concentrations in the base flow of four streams in Queens County ranged from 88 to $124 \mathrm{mg} / \mathrm{L}$, whereas those in 12 streams in Nassau County ranged from 53 to $67 \mathrm{mg} / \mathrm{L}$ (Burr, Herıng, and Freeman, 1904, p 406-423) (Base-flow samples represent ground water that originated over large areas of the land surface and thus are reliable ind1cators of ground-water quality )

\section{Dissolved Solids}

The dissolved-solids concentration of water in all aquifers on Long Island is generally low compared to that in most other places and ranges from 15 to 53 $\mathrm{mg} / \mathrm{L}$ (table 3) This is due to the lack of soluble minerals in the aquifer materials (Cohen and others, 1968) The highest dissolved-solids concentrations are in the Lloyd aquifer, probably because this water has traveled longer and farther through the ground-water system than water in the other aquifers and has had a greater contact time in which to react with the aquifer material

\section{EFFECTS OF URBANIZATION ON THE HYDROLOGIC SYSTEM}

Ground water on western Long Island was developed rapidly in the early 19 th century along with the rapid population growth in Kings and western Queens Counties The early residents obtained water from shallow wells and from streams (which are primarily base flow) and springs and returned most of it to the aquifer through septic systems This withdrawal and return probably caused only minor changes in the 
water-table configuration and in shallow ground-water flow patterns

As the demand for public and industrial water supply increased, the number of wells and the quantity pumped also increased, increasing the infiltration of wastewater contaminants introduced to the groundwater system In the mid-19th century, storm and sanitary sewers were installed in Kings and discharged wastewater to the sea Although this prevented contaminants from entering the ground-water system, it also diverted a large quantity of water that would have recharged the ground-water system At the same tıme, the ever-1ncreasing amounts of paved land surface reduced the area avallable for infiltration of precipitation, further decreasing recharge By the 1930's, these changes, along with the continuous increase in industrial and water-supply pumpage, caused severe declines in the water table and in the hydraulic head in the deeper aquifers Declines in the water-table altitude caused many lakes and streams to disappear and severely decreased the flow in remaining streams At the same time, the decrease in hydraulic head caused intrusion of saltwater into the aquifers in nearshore areas

\section{Development of Ground-Water Supply}

Pumping for industrial and public supply in the 20th century has imposed a severe stress on the western part of the Long Island ground-water system Ground water pumped and lost either by evaporation or discharge to the sea is considered consumptive (net) pumpage and is a net draft on the ground-water system

Virtually all of the ground water pumped in western Long Island is lost either through evaporation or to combined (storm and sanitary) sewers with ocean outfall Developed parts of Kings and Queens had an extensive sewer network by the turn of this century As a result, only a small, undetermined fraction of pumped ground water infiltrated back to the ground-water system in unpaved areas and from leaking sewer and water-supply lines

\section{History of Ground-Water Development}

Public-supply and industrial pumpage from 1904-83 are plotted in figure 5 (No data are avallable for industrial pumpage in Queens County before 1948, 1t probably was considerably less than in Kings County but followed similar trends ) Pumpage and ground- water development through the 20th century are summarızed in four general phases, described below

\section{0 to 1917}

By 1900 , the ground-water reservoir of western Long Island was used extensively for both public-supply and industrial uses Johnson and Waterman (1952, p 7) estımate that in 1904, $64 \mathrm{Mgal} / \mathrm{d}$ was obtained from surface storage of ground-water-fed springs and streams in Queens County, and $774 \mathrm{Mgal} / \mathrm{d}$ was obtained from surface storage from nearby Nassau County

By 1904, pumpage for public supply had reached $14 \mathrm{Mgal} / \mathrm{d}$ in Kings County and $28 \mathrm{Mgal} / \mathrm{d}$ in Queens, most of which was used in Kings County The average pumpage for public supply during 1909-16 was 30 $\mathrm{Mgal} / \mathrm{d}$ in Kings County and $58 \mathrm{Mgal} / \mathrm{d}$ in Queens County (fig 5) Industrial pumpage in 1904, although only a few million gallons per day in Queens, was 14 $\mathrm{Mgal} / \mathrm{d}$ in Kings County and increased markedly in both counties thereafter

In 1917, New York City water tunnel 1 was completed, and surface water from reservoirs in upstate New York was transported to the water-supply-distributıon system in Kings and Queens This water replaced a significant amount of ground-water pumpage, as ind1cated in figure 5 The City of New York, Department of Water Supply, Gas, and Electricity, which had pumped more than $14 \mathrm{Mgal} / \mathrm{d}$ in Kings County and $40 \mathrm{Mgal} / \mathrm{d}$ in Queens County durıng the preceding 10 years, all but ceased pumping in 1917

\section{8 to 1930}

The post-World War I period in western Long Island was marked by a consistent increase in consumptive ground-water use for both public supply and industrial use After the abrupt reduction in pumpage for public supply in 1917, contınued demand resulted in an increase in public-supply pumpage from $13 \mathrm{Mgal} /$ d in Kings County and $231 \mathrm{Mgal} / \mathrm{d}$ in Queens in 1918 to $292 \mathrm{Mgal} / \mathrm{d}$ and $620 \mathrm{Mgal} / \mathrm{d}$, respectıvely, in 1931 (fig 5) Industrial pumpage also continued to increase and, by 1930, had exceeded $50 \mathrm{Mgal} / \mathrm{d}$ in Kings County and was probably about $20 \mathrm{Mgal} / \mathrm{d}$ (estımated by the authors) in Queens

\section{1 to 1946}

Pumping for public supply during this period was relatıvely constant in Kings County but ranged 

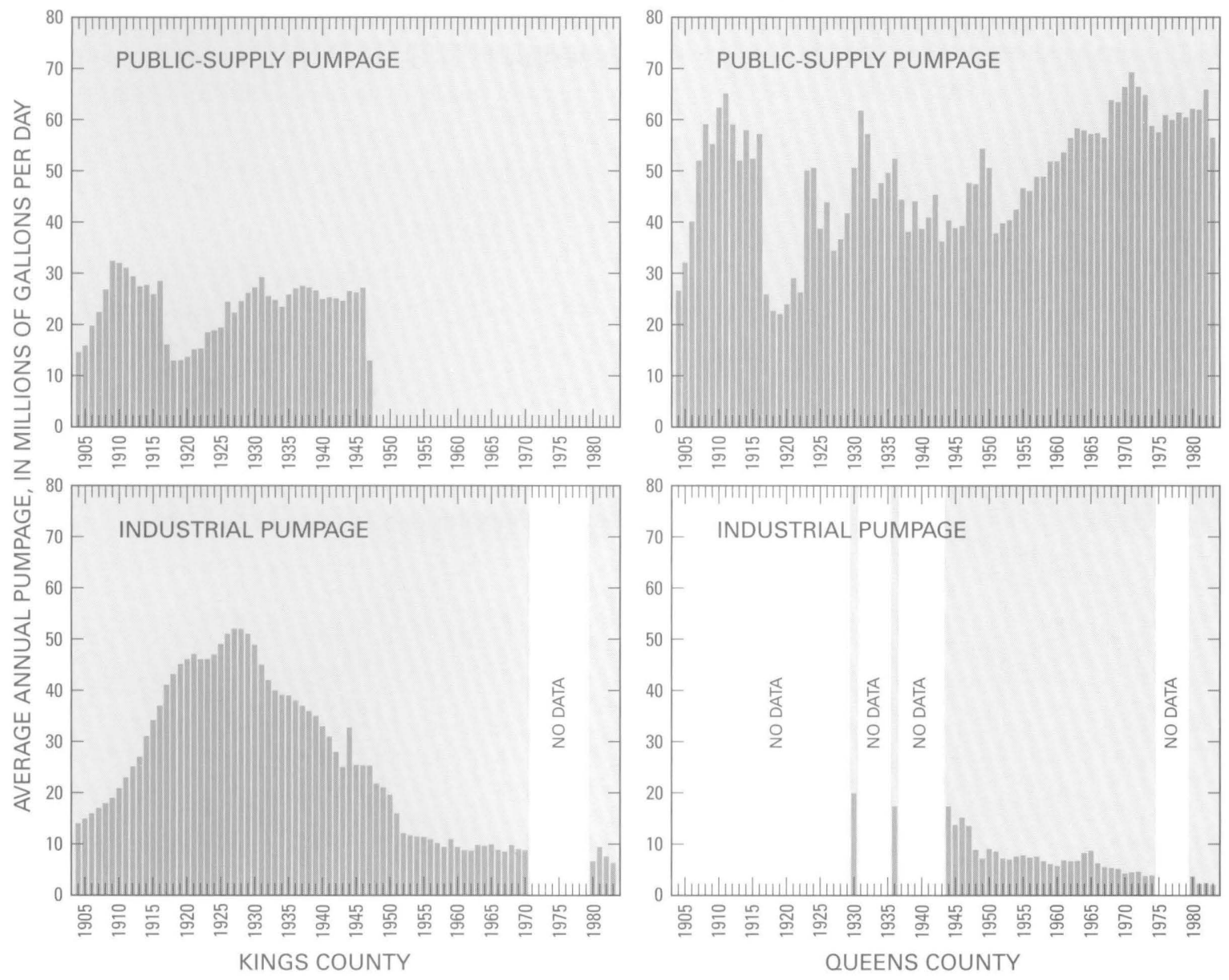

Figure 5. Annual average pumpage for industrial and public supply in Kings and Queens Counties, 1904-83. (Compiled from Johnson and Waterman, 1952; Thompson and Leggette, 1936; Suter, 1937; and New York State Department of Environmental Conservation.)

from more than 60 to less than $40 \mathrm{Mgal} / \mathrm{d}$ in Queens. In 1936, tunnel 2 was completed and increased the capacity to supply upstate surface water to Kings and Queens. The effect is not evident in ground-water pumping data for Kings and may have caused only a minor decrease in Queens (fig. 5). Much of the imported water probably was used for conversion of new areas to public supply.

The 1930's brought a noticeable decline in industrial pumpage (fig. 5) for two major reasons:

1. Concern over the extensive use of ground water by industry prompted the adoption of the New York State Water Conservation Law of 1933, which required that water pumped at a rate greater than $70 \mathrm{gal} / \mathrm{min}(0.1 \mathrm{Mgal} / \mathrm{d})$ be reinjected into the source aquifer after use. (Ground water pumped for industrial use and returned to the source aquifer is not included in the net pumpage shown in fig. 5.) Leggette and Brashears (1938, p. 413) estimate that only one recharge well was operat- ing in western Long Island at the end of 1933, but by 1937 , the number had increased to 105 . The average daily rate of recharge reached a high of 22 $\mathrm{Mgal} / \mathrm{d}$ in the air-conditioning season during these years but maintained an average annual rate of about $12 \mathrm{Mgal} / \mathrm{d}$.

2. The widespread adoption of electric refrigeration severely reduced the quantity of water pumped for ice making. Lusczynski (1952, p. 4) states that the quantity of water pumped for ice-making during 1936-47 decreased from $18 \mathrm{Mgal} / \mathrm{d}$ to $4 \mathrm{Mgal} / \mathrm{d}$.

During World War II (1940-45), industrial pumpage increased slightly in Kings County; a similar increase was likely in Queens County.

\section{7 to 1983}

In 1947, New York City stopped all public-supply pumping in Kings County, primarily because of 
saltwater intrusion, but pumping for public supply continued in Queens, where it increased from $45 \mathrm{Mgal} / \mathrm{d}$ in 1950 to more than $60 \mathrm{Mgal} / \mathrm{d}$ in the 1970's (fig. 5). The trend of pumping in Queens has been to abandon wells showing contamination and to install new ones eastward and farther inland, where water levels are higher.

Pumpage declined in 1974 (fig. 5), when all pumping for public supply $(10 \mathrm{Mgal} / \mathrm{d})$ in the Woodhaven franchise area (fig. 6A) of the New York Water Service Corporation (NYWSC) was halted as a result of saltwater intrusion. Industrial pumpage declined gradually in both counties and fell below 10 $\mathrm{Mgal} / \mathrm{d}$ in Kings and $3 \mathrm{Mgal} / \mathrm{d}$ in Queens.

\section{Development of Individual Aquifers}

Annual average pumpage for public supply in Kings and Queens during 1904-83 is plotted by aquifer in figure 6. Such a breakdown for industrial pumpage is unavailable, but most pumping for industrial pur-
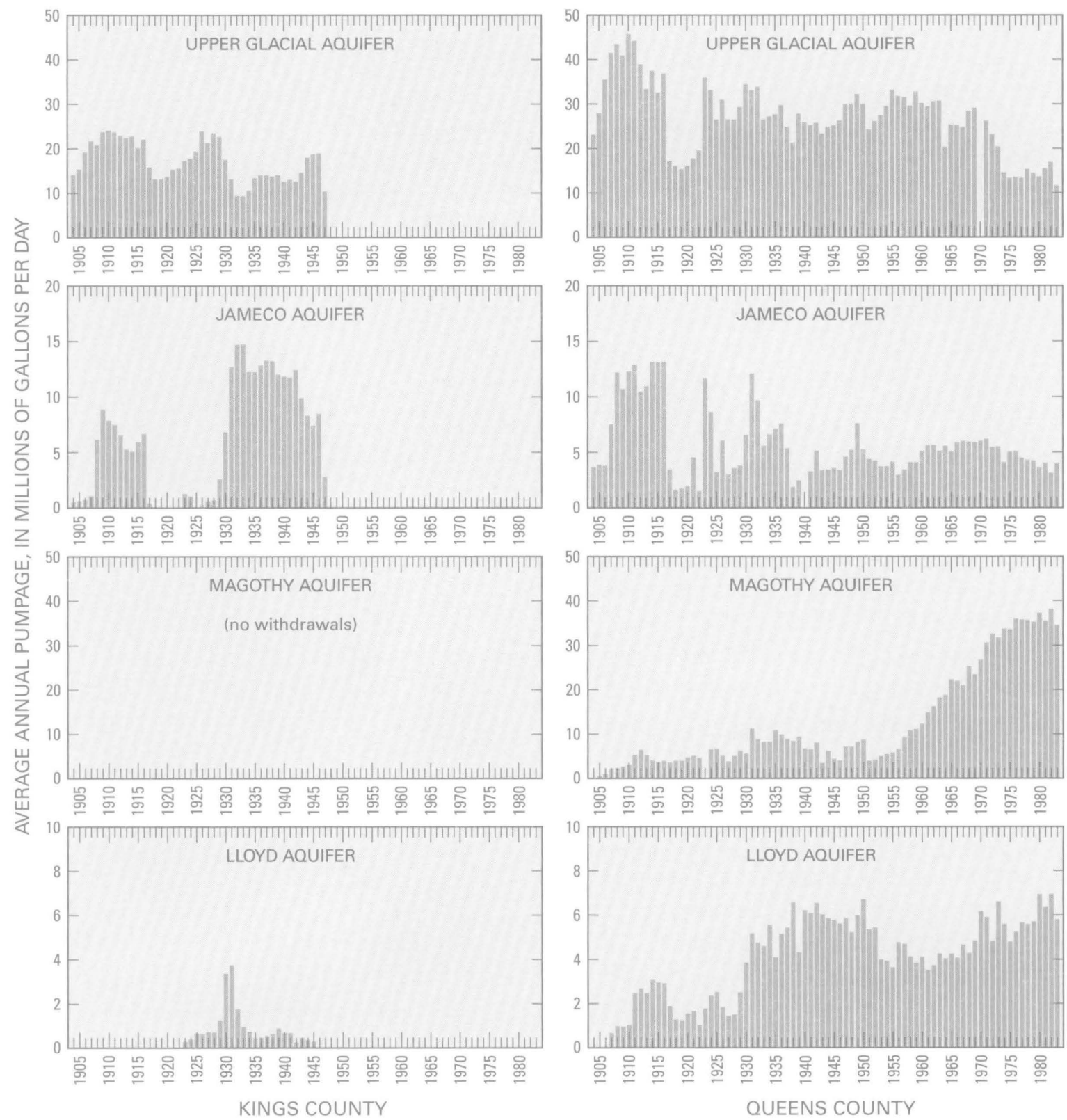

Figure 6. Annual average public-supply pumpage from individual aquifers in Kings County (left) and Queens County (right), 1904-83. (Compiled from Johnson and Waterman, 1952; and New York State Department of Environmental Conservation; pumpage records obtained from the New York Water Service Corporation and Jamaica Water Supply Company.) 
poses probably has been from the upper glacial (watertable) aquifer

Early in this century (1904-17), most groundwater pumpage was derived from the upper glacial aquifer, it attained a maximum of $70 \mathrm{Mgal} / \mathrm{d}$ in 1910 (24 $1 \mathrm{Mgal} / \mathrm{d}$ in Kings and $460 \mathrm{Mgal} / \mathrm{d}$ in Queens) At the same time, pumping from the Jameco was 205 $\mathrm{Mgal} / \mathrm{d}$ (8 Mgal/d in Kings and $125 \mathrm{Mgal} / \mathrm{d}$ in Queens), and pumping from the Magothy aquifer was about $5 \mathrm{Mgal} / \mathrm{d}$ (No water was pumped from the Magothy aquifer in Kings County throughout 1904-83 because this aquifer is not extensive there ) Pumping from the Lloyd aquifer started as early as 1905 but reached a maxımum of only about $3 \mathrm{Mgal} / \mathrm{d}$ durıng 1904-17

Pumping from the upper glacial and Jameco aquifers decreased substantially in 1917 with the completion of the first water tunnel to bring upstate surface water to the city, but in the following years, pumping from all aquifers gradually increased A distınct shift in pumping from the upper glacial to the Jameco aquifer in Kings County is evident during 1928-33 (fig 6), pumpage from the upper glacial aquifer decreased from $234 \mathrm{Mgal} / \mathrm{d}$ in 1928 to $95 \mathrm{Mgal} / \mathrm{d}$ in 1933, while pumping from the Jameco aquifer increased from 08 $\mathrm{Mgal} / \mathrm{d}$ to $149 \mathrm{Mgal} / \mathrm{d}$ This shift was in response to saltwater intrusion, which by 1947 had caused the cessation of all public-supply pumping in Kings County.

A simılar shift from the upper glacial aquifer to the Magothy aquifer occurred in Queens County during 1955-76, when pumping from the upper glacial aquifer decreased from $330 \mathrm{Mgal} / \mathrm{d}$ to $13.9 \mathrm{Mgal} / \mathrm{d}$, and pumping from the Magothy aquifer increased from $59 \mathrm{Mgal} /$ $\mathrm{d}$ to $365 \mathrm{Mgal} / \mathrm{d}$ This shift also was due, at least in part, to saltwater intrusion, which ultimately caused the shutdown of pumping in the Woodhaven Franchise area of the NYWSC (See fig 7A)

Pumping from the Lloyd and Jameco aquifers in Queens County has remained relatively stable since the 1930's, and pumping from the Lloyd in Kings County has been almost negligible-1t exceeded $1 \mathrm{Mgal} / \mathrm{d}$ only during 1929-32, with a maximum of $36 \mathrm{Mgal} / \mathrm{d}$ in 1931

\section{Declines in Water Levels}

The most marked effect of urbanization on the hydrologic system of western Long Island has been a decline in the water table and in the potentiometric surface of the deeper aquifers The configuration of the water table before development was discussed prev1ously (see fig 4), water-table maps for subsequent years (figs 7A-7E) depict the changes resulting from urbanization and related stresses during the 20th century

By 1936, the water table showed severe declines resultıng from heavy pumping and loss of recharge (Compare figs 4 and 7A ) An asymmetric cone of depression in northern Kings County, an area of extensive industrial pumping at that time, reached a depth of $35 \mathrm{ft}$ below sea level and extended into western Queens County

The decline in industrial pumping that started around 1930 (fig 5) resulted in some recovery of the water table by 1943 (fig 7B) (Note that the water table in northern Queens County was not contoured, poss1bly because, at that time, Jacob (1945) was uncertain whether anomalous high water levels were perched or were the actual water-table surface ) The water-table configuration of 1943 showed a partial recovery in northern Kıngs and western Queens Counties

After the cessation of pumping for public supply in Kings in 1947, the water table recovered further The water-table configuration of 1951 (fig 7C) shows a rise in the southern half of Kings County to altitudes above sea level, and the cone of depression in the north is smaller and shallower than in 1936 (fig 7A)

By 1961, the water table (fig 7D) had risen to above sea level throughout Kings County except in a small area in the north Perlmutter and Soren (1962, p 128) report that the dewatering rates at several subway stations in Flatbush increased from less than $20 \mathrm{gal} / \mathrm{min}$ in 1947 to as much as $1,000 \mathrm{gal} / \mathrm{min}$ by 1961

A sizable cone of depression is evident in the Woodhaven franchise area in Queens County, where pumping increased in response to a contınuing rise in demand The cone of depression extended into Jamaica, where pumpage by the Jamaica Water Supply Company in 1961 was nearly $50 \mathrm{Mgal} / \mathrm{d}$ Although the cone of depression in 1961 was not as deep as that in Kings County in the 1930's (fig 7A), the initial water levels in Queens County were $20 \mathrm{ft}$ higher than in Kings, so that the respective declines represent similar losses in ground-water storage

By 1974, the water table had recovered further in Kings County (fig 7E), and the cone of depression in Queens had shifted from Woodhaven, where pumping stopped in 1974, eastward to Jamaica, where the Jamaica Water Supply Company was pumping about $60 \mathrm{Mgal} / \mathrm{d}$ Water levels in this cone of depression rep- 


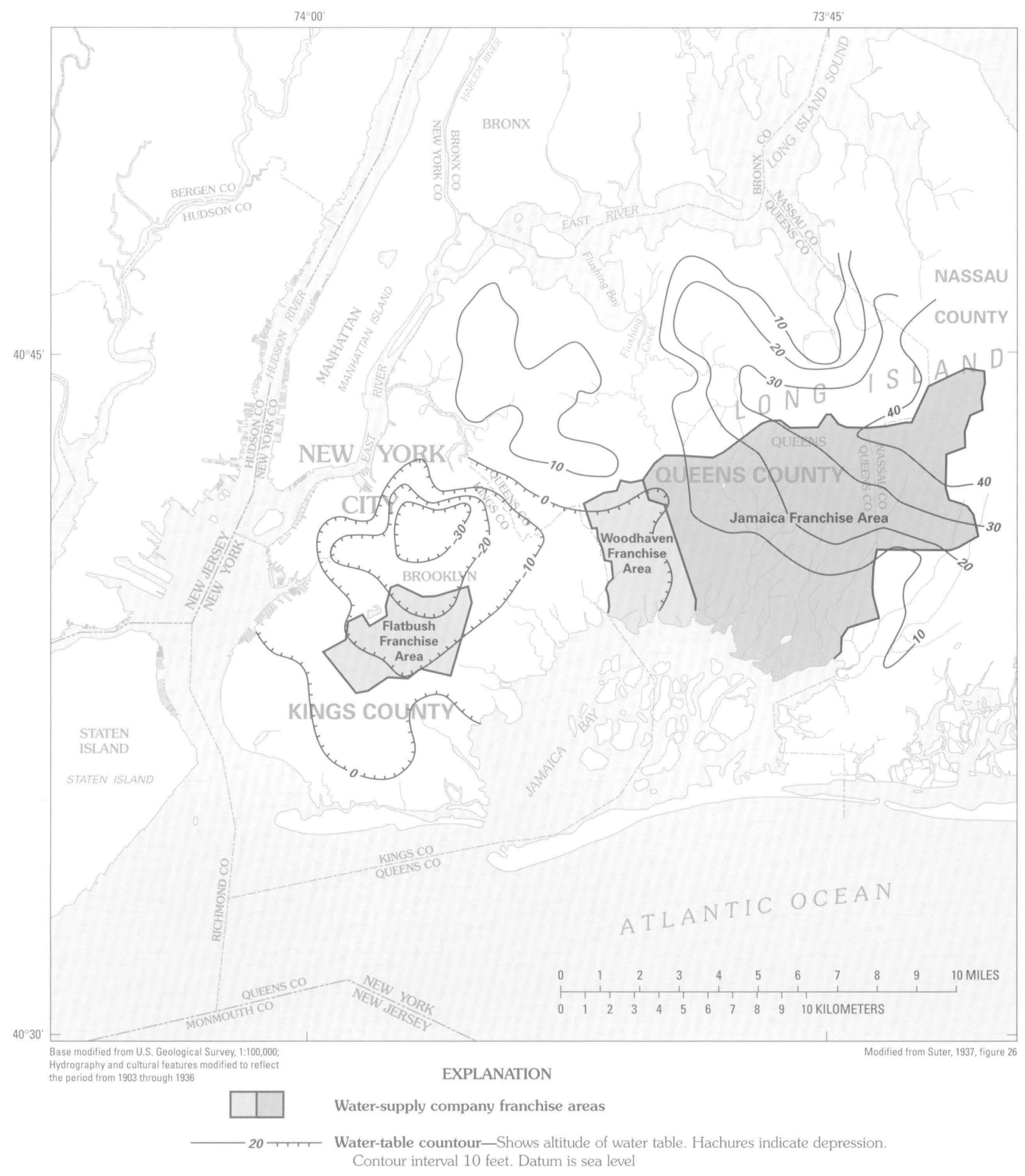

Figure 7A. Water-table configuration in 1936.

resent a regional drawdown of about $35 \mathrm{ft}$ from water levels in 1903 (fig. 4).

Similar declines in the potentiometric surface of the deeper aquifers have resulted from increased pumping and urbanization. Historical data on the potentio- metric surface of these aquifers are sparse, but recent water-level records for wells screened in the deeper aquifers confirm that drawdown propagates rapidly from one aquifer to the next in areas where confining units are absent. Pumping confined parts of the deeper 


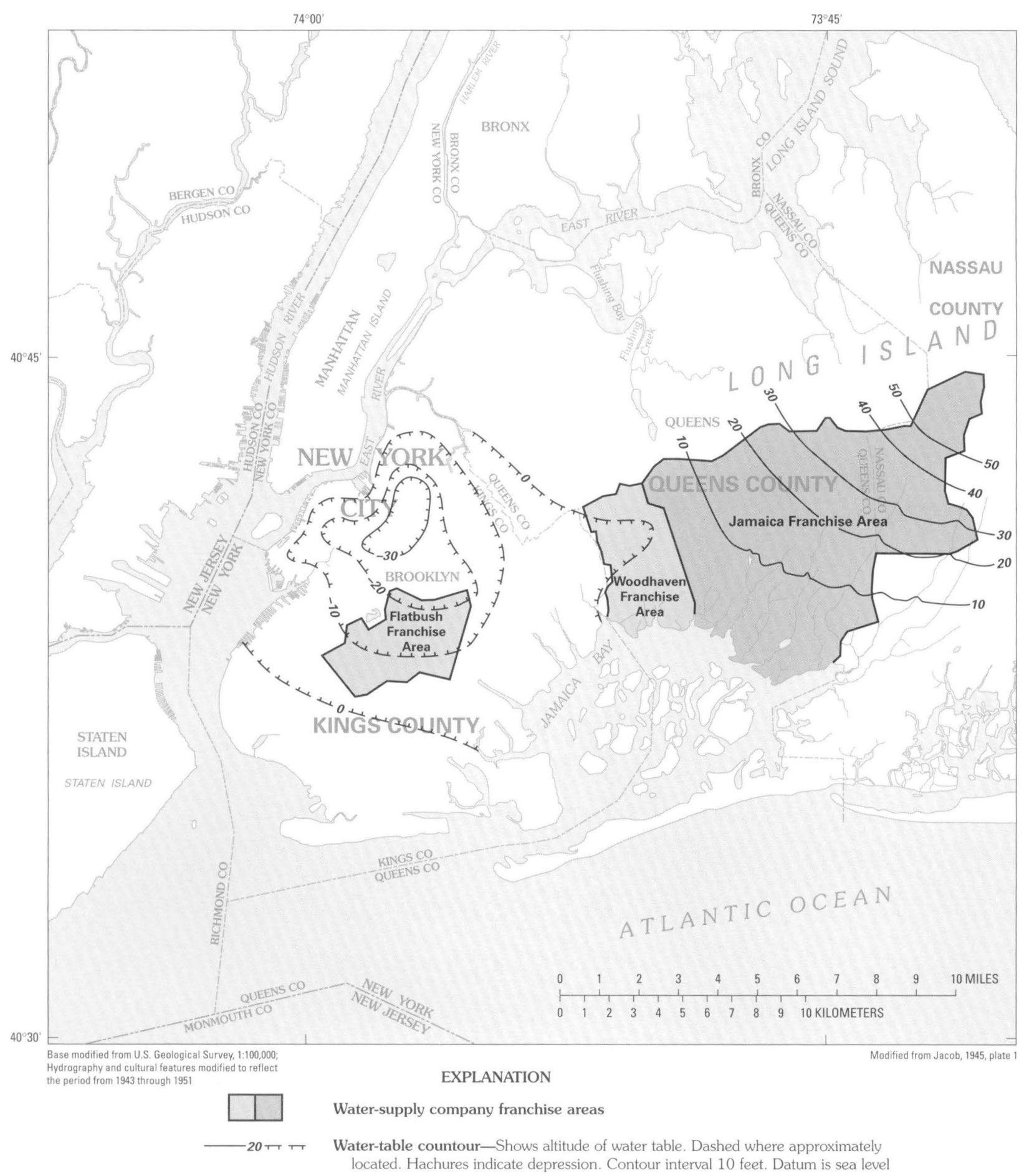

Figure 7B. Water-table configuration in 1943. (Water levels were measured in late May.)

aquifers produces a cone of depression within the pumped aquifer that is broader than the one in the water-table aquifer. Because confined storage coefficients are typically much lower than the specific yield of the water-table aquifer, the transient response to stress is more rapid in the deeper aquifers. Also, the absence of local stream and surface-water boundaries in confined aquifers forces propagation of drawdown to more distant boundaries. 


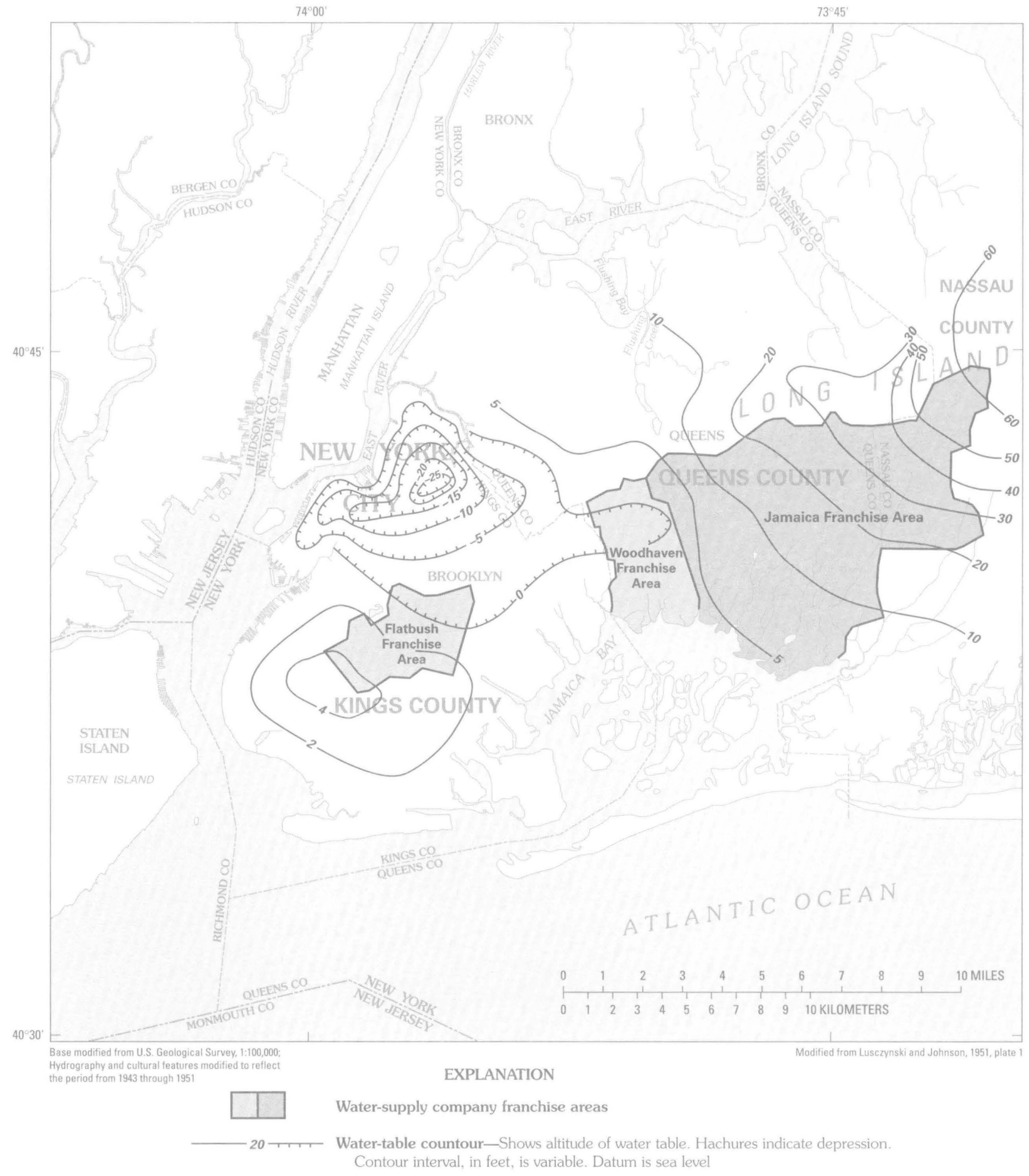

Figure 7C. Water-table configuration in 1951. (Water levels were measured in January.) 


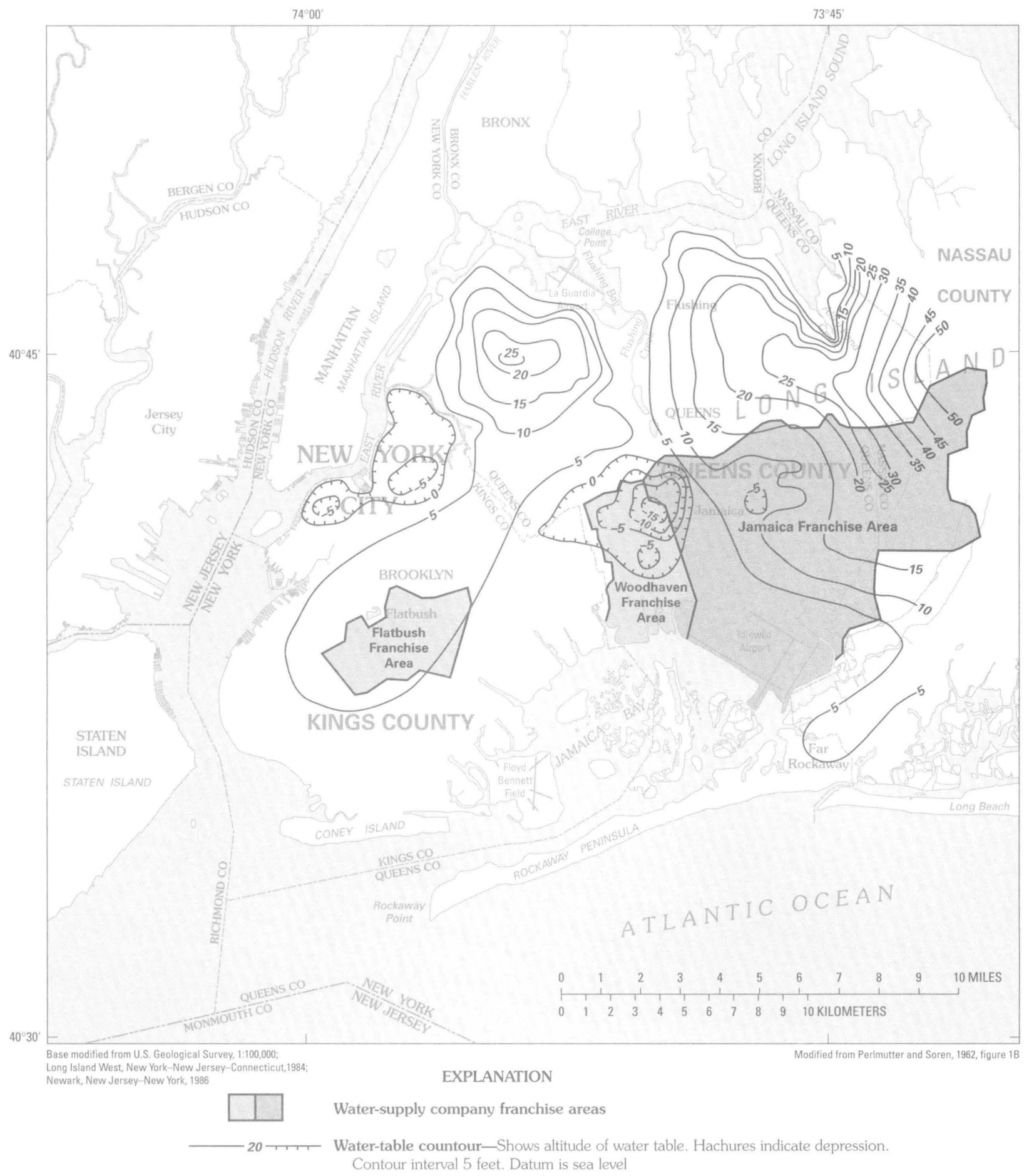

Figure 7D. Water-table configuration in 1961. (Water levels were measured in December.) 


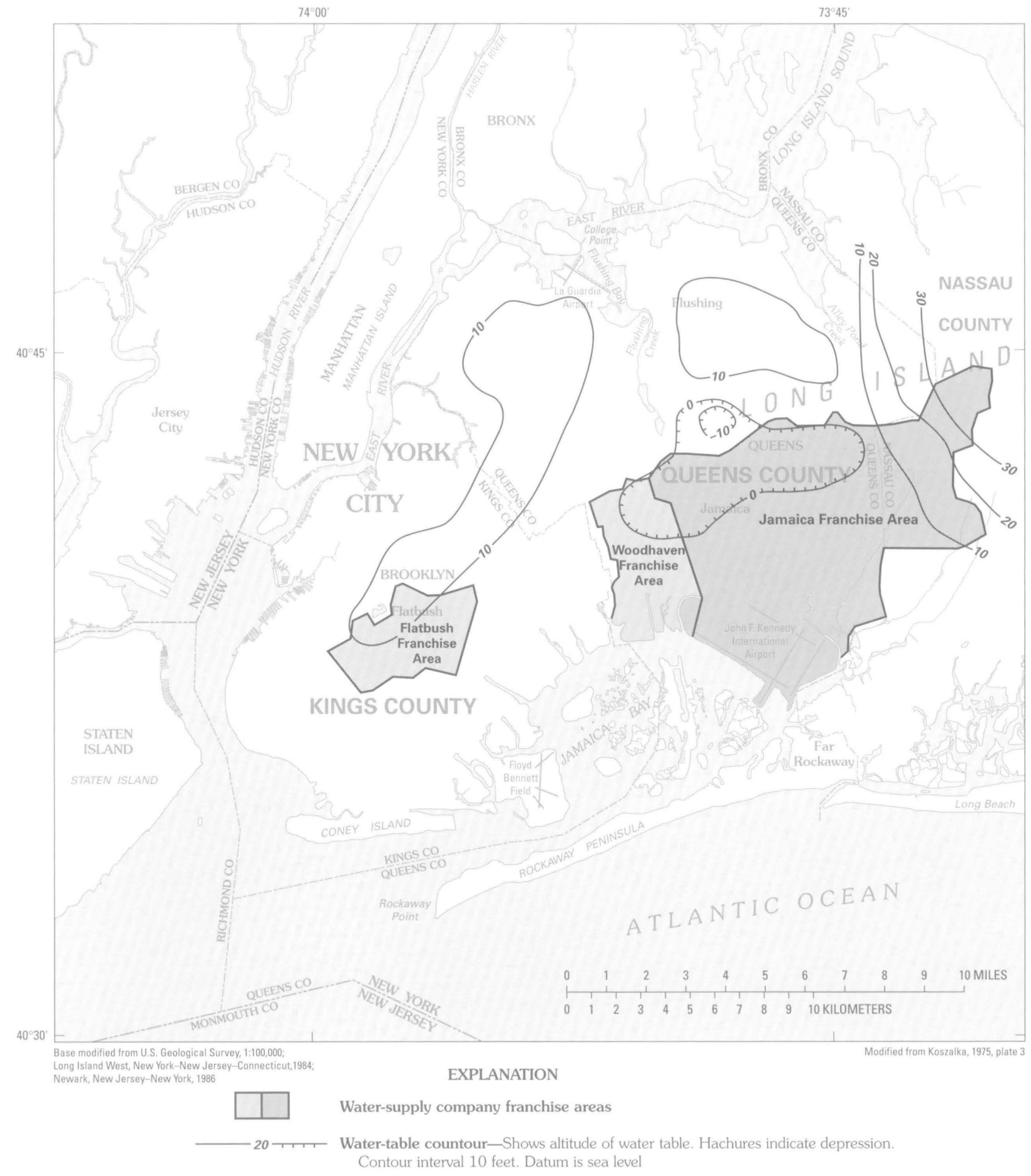

Figure 7E. Water-table configuration in 1974. (Water levels were measured in March.) 


\section{Deterioration of Ground-Water Quality}

In addition to lowering ground-water levels in Kings and Queens Counties, urbanization and development of the ground-water resources have caused serious deterioration of ground-water quality. The most striking example has been the encroachment of saltwater from surrounding saltwater boundaries in response to excessive drawdown. Other sources of contamination, some of which were present from the early stages of development, include fertilizers, underground sewage-disposal systems, landfills, large cemeteries, road salts, leaking sewers, chemical spills at land surface, and industrial and other wastewater impoundments.

Historical water-quality data are sparse, but chloride and nitrate data were collected as far back as 1900 and are used here to give an indication of changes in ground-water quality during this century. Elevated chloride concentrations accompanied by very low nitrate concentrations generally are considered indicative of seawater encroachment, whereas elevated nitrate and chloride together are considered to indicate contamination from land surface.

Nitrate and chloride are among the earliest contaminants to be introduced to the ground-water system. They first entered the system on a widespread basis about 200 years ago as fertilizers and domestic wastes and are considered indicators of water that has been affected by human activities.

\section{Chloride}

Encroachment of saline ground water has affected public-supply wells in western Long Island since the turn of this century. Spear (1912) shows the increase in chloride in water pumped from driven wells at the Shetucket pumping station near Jamaica Bay during 1897-1905 (fig. 8). Chloride concentrations rose to $500 \mathrm{mg} / \mathrm{L}$ in these 9 years. Once saline ground water was drawn into the area of the pumping wells, even a significant reduction in pumping rate did little to improve water quality.

Later, pumping wells were installed inland to avoid the saline ground water. By the early 1930's, however, high pumping rates had caused saltwater intrusion even in inland areas. A sharp increase in chloride concentration in water from two public-supply wells screened in the upper glacial aquifer in the Flatbush franchise area occurred during the 1940's (fig. 9A). Saline ground water probably was drawn this far inland from beneath surrounding tidal waters by the expanding cone of depression that extended to shore areas. The migration of saltwater so far inland during this period probably indicates that saline ground water moved through preferential and highly conductive pathways. The water-table configuration of 1903 (fig. 4) shows seaward gradients; that of 1936 (fig. 7A) indicates a change to flat or slightly landward gradients near much of the shore in Kings County, which would
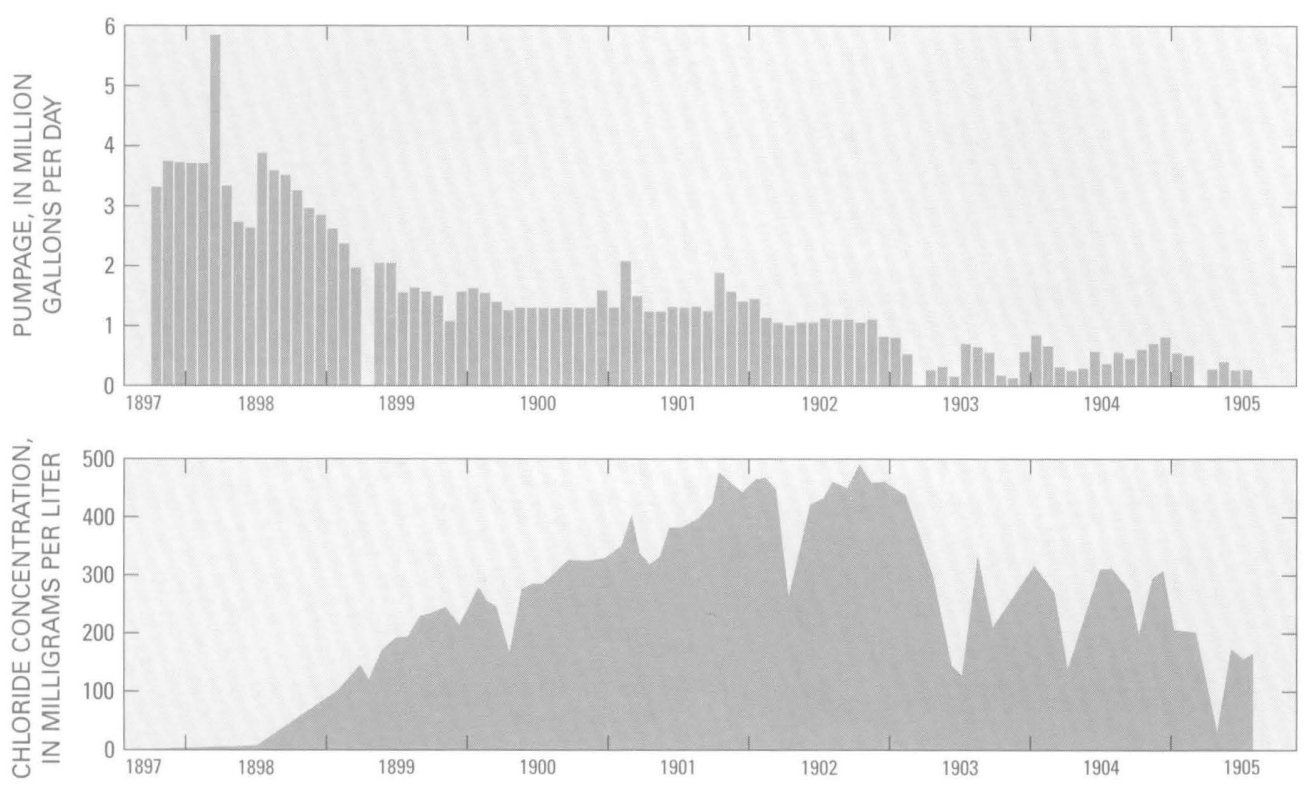

Figure 8. Total pumpage and average chloride concentration from eight driven wells at the Shetucket pumping station, 1897-1905. (From Spear, 1912, sheet 12.) 

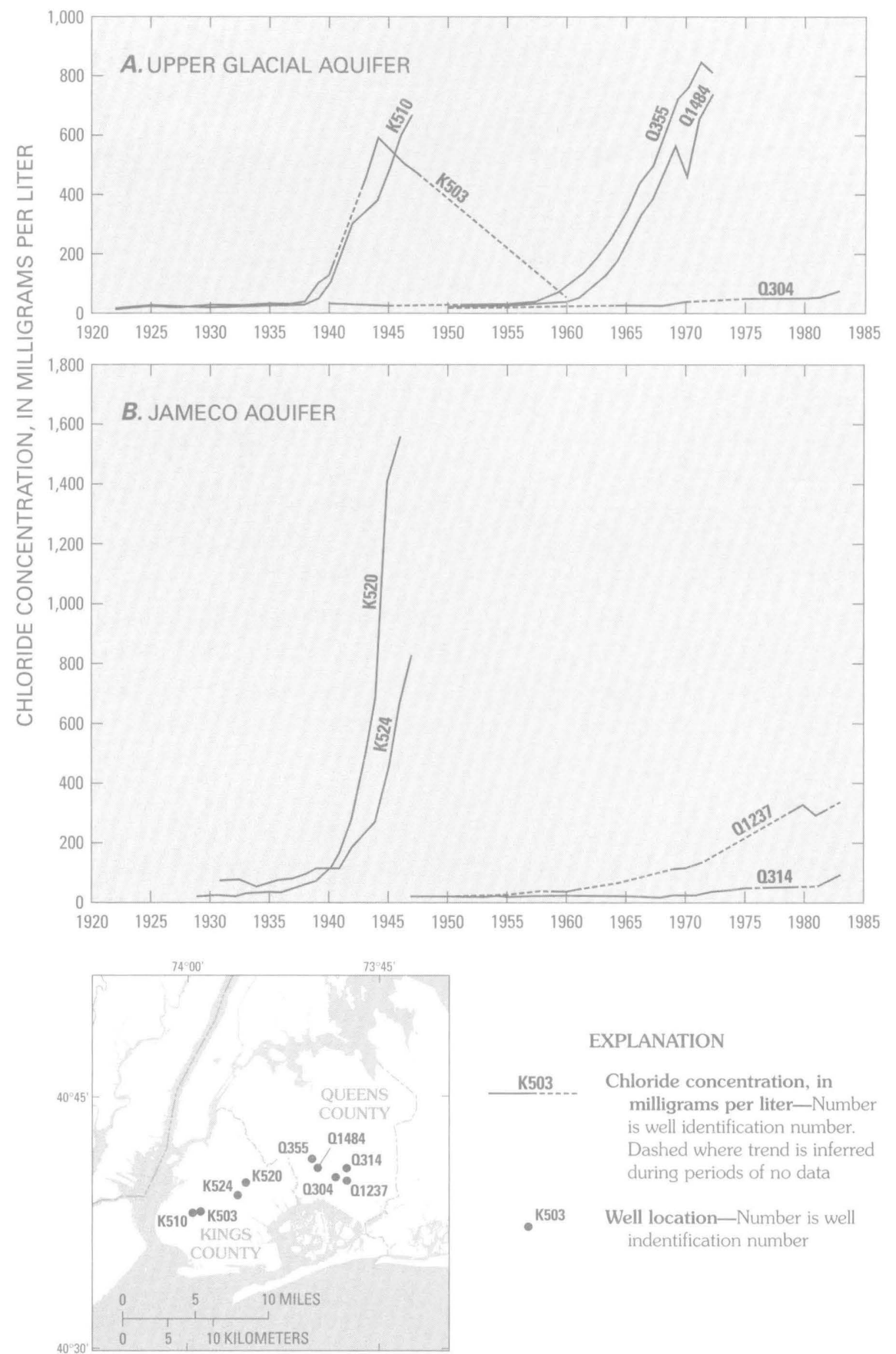

EXPLANATION

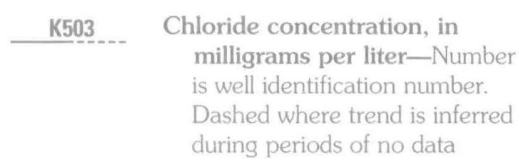

K503 Well location-Number is well indentification number

Figure 9-Chloride concentration in water from selected wells in Kings and Queens Counties: (A) Wells screened in the upper glacial aquifer. (B) Wells screened in the Jameco aquifer. (Data from U.S. Geological Survey files; Lusczynski, 1952; and selected annual reports of the Bureau of Water Supply, City of New York.)

accelerate saltwater encroachment. Pumping was stopped in wells in Kings County in 1947 (see fig. 9A).

When the chloride concentration of water from the upper glacial aquifer began to increase, pumping was shifted eastward and to deeper aquifers, but a similar increase in chloride concentration in the deeper aquifers soon followed (fig. 9B). The transient response of water levels in the confined aquifers to pumping is quicker than that in the water-table aquifer; that is, changes in hydraulic head are transmitted more rapidly, and saltwater intrusion follows. Lusczynski (1952, p. 5-6) indicates that, during the 1930's and 1940 's saltwater intrusion into the Jameco aquifer was more rapid than in the upper glacial aquifer and 
extended farther inland and caused higher chloride concentrations The rise in chlonde concentration at two wells screened in the Jameco aquifer is more rapid than at corresponding wells screened in the upper glacial aquifer (Compare figs 9A and 9B )

The Lloyd aquifer shows no evidence of saltwater intrusion, most likely because it is tapped by only a few wells Pumpage frcm the Lloyd in Kings County began in 1920 and, untıl 1940, averaged less than 1 $\mathrm{Mgal} / \mathrm{d}$ (fig 6) Well K464, on the western shore of Iamaica Bay and screened in the Lloyd aquifer (pl 1), had chlonde concentrations of 6 to $10 \mathrm{mg} / \mathrm{L}$ during 1937-50 High chloride concentrations were measured in water from this well in 1950, but because this was immediately after repair work had been done on these wells, it is probably a result of a damaged well casing that allowed shallow salıne ground water to contamınate the well

The maximum recommended concentration of chloride in community water systems is $250 \mathrm{mg} / \mathrm{L}$ (New York State Department of Health, 1977) - the approximate taste threshold for most people By 1940, public-supply water in Kings County had begun to exceed this amount, and, by 1947 , chloride contamination in the upper glacial aquifer was widespread (fig 10A) Although background chloride concentrations are probably $10 \mathrm{mg} / \mathrm{L}$ or less (see previous section), much of the shallow ground water in Kings County had been affected to some degree by chloride contamination from land surface (fig 10A) Therefore, $40 \mathrm{mg} / \mathrm{L}$ has been used as a background level for chloride in shallow ground water (Soren, 1971)

Chlonde concentrations at wells near the shore had reached 1,000 to $8,000 \mathrm{mg} / \mathrm{L}$ by 1947 , and the concentrations inland were as high as $700 \mathrm{mg} / \mathrm{L}$ At the same time, chloride concentrations in the Jameco aquifer in Kings County were as high as $1,500 \mathrm{mg} / \mathrm{L}$ Queens County in 1947 had only traces of chlonde in the upper glacial aquifer, however (figs 9A and 10A)

Pumpıng in Queens County increased sharply in the early 1950's (figs 5 and 6) and was accompanied by an increase in chloride concentrations Water from two wells that tap the upper glacial aquifer in the Woodhaven franchise area (fig 9A) showed a marked increase in chlonde concentration from the late 1950's untıl 1974, when pumping for public supply (which was entırely from the upper glacial aquifer) in that area was stopped

The map in figure 10B indicates that, in 1960, water from much of the upper glacial aquifer in western
Queens County had chloride concentrations greater than $40 \mathrm{mg} / \mathrm{L}$ Chloride contamination appears to be greatest in shore areas and in the cone of depression around pumping centers in the Woodhaven franchise area (fig 7D) and is largely the result of saltwater intrusion

Some of the chlonde contamination in Queens County is undoubtedly derived from inland surface sources, especially in northwestern Queens, which has been extensively developed since the 19th century and where water-table gradients indicate that saltwater intrusion is unlikely

Chlonde concentrations in Kings County in 1960 (fig 10B) appear to show a decrease since the cessation of pumping in 1947 through dilution and the gradual recovery of ground-water levels (fig 7D) Water at well K503 in 1960 (fig 9A) shows a considerable decrease in chloride concentration since 1947

By 1970, chloride contamination in the Woodhaven franchise area had become even more extensive (figs 7E and 10C), and, by 1974, pumping for public supply had been stopped because of saltwater intrusion Chloride contamination in the Jamaica area in 1970 was stıll virtually negligible (fig 10C)

Wells in the Jamaica Water Supply Company area (southeastern Queens County) - Q304 in the upper glacial aquifer and Q1237 and Q314 in the Jameco aquifer (fig 9) -all show a steady increase in chloride concentration since the 1960's This could be a forewarnıng of sharp increases similar to those that occurred in western Queens in the 1960's and in Kings in the 1940's

\section{Nitrate}

Nitrate is the predominant form of nitrogen found in ground water After introduction at the water table, it has been found to be a persistent indication of contamination from land surface The first introduction of nitrate to ground water resulted from domestic waste disposal and agricultural sources, which became widespread about 200 years ago Other sources of nitrate are leakıng sewer lines and leachate from landfills Because elevated nitrate concentrations in water can be harmful, a limit of $10 \mathrm{mg} / \mathrm{L}$ nitrate (as nitrogen) is defined as drinkıng-water standard (New York State Department of Health, 1977) Data on nitrate concentrations in the upper glacial aquifer in Kings County during 1897-1916 (Kımmel, 1972) indicate that ground water in developed areas was already contaminated by the turn of this century Nitrate concentrations (as 


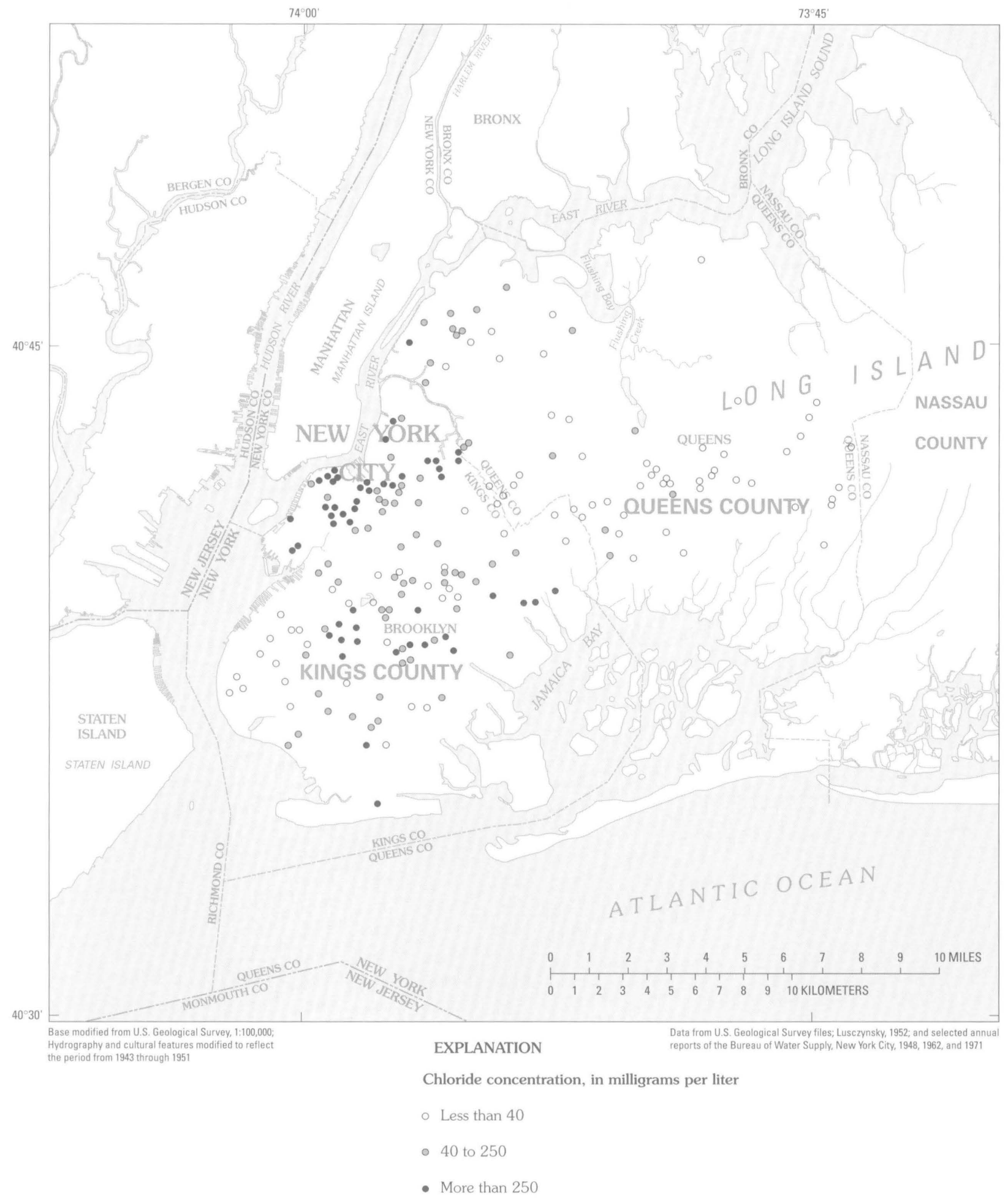

Figure 10A. Chloride concentrations in the upper glacial aquifer in Kings and Queens Counties in 1947. 


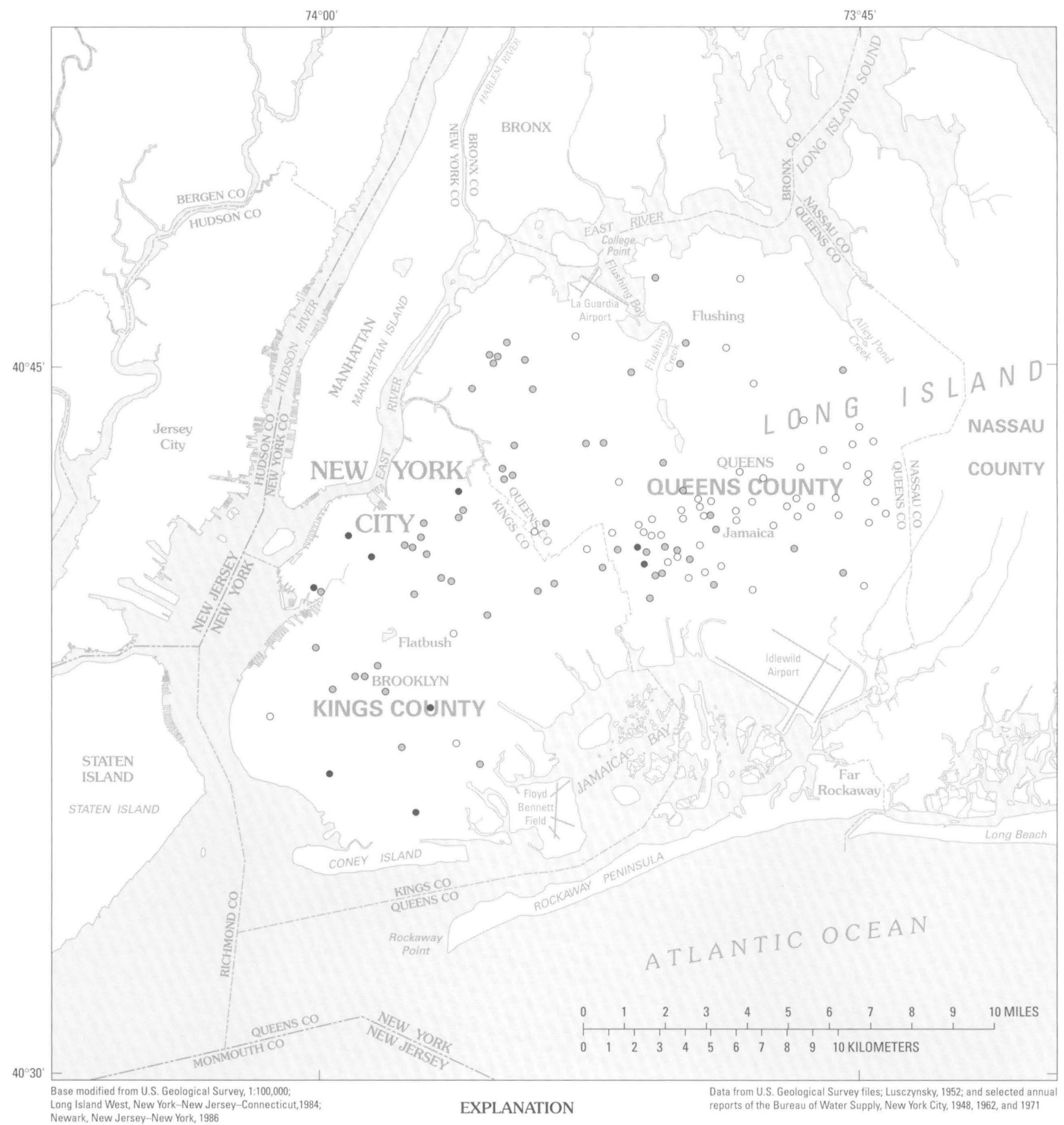

Chloride concentration, in milligrams per liter

- Less than 40

- 40 to 250

- More than 250

Figure 10B. Chloride concentrations in the upper glacial aquifer in Kings and Queens Counties in 1961. 


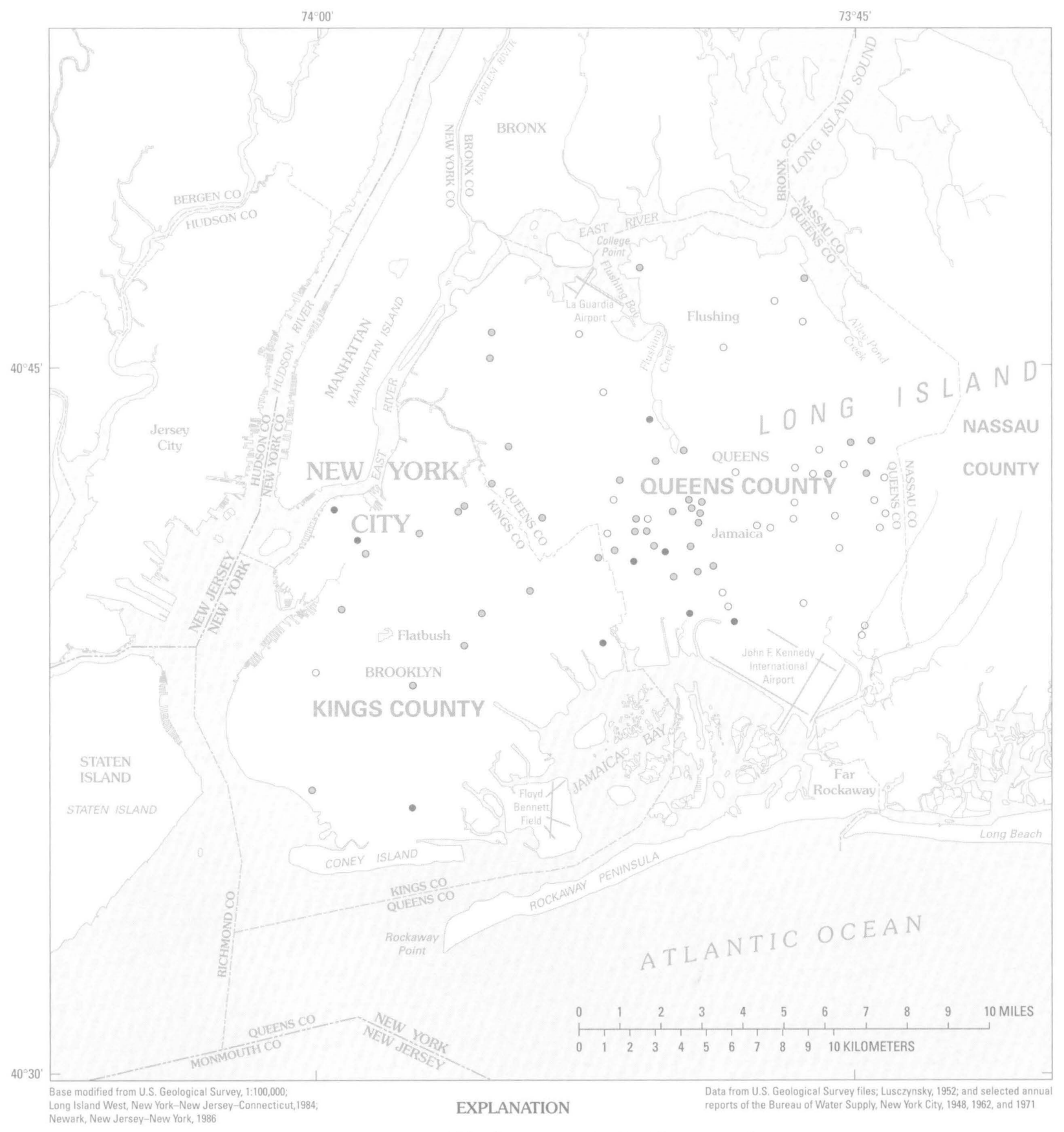

Chloride concentration, in milligrams per liter

- Less than 40

- 40 to 250

- More than 250

Figure 10C. Chloride concentrations in the upper glacial aquifer in Kings and Queens Counties in 1970. 
nitrogen) in 13 of 14 wells in Kings sampled in 1942 ranged from 6 to $25 \mathrm{mg} / \mathrm{L}$ (Kımmel, 1972), the concentration in the remaining well was $2 \mathrm{mg} / \mathrm{L}$

Data on nitrate contamınation of the deeper aquifers in Kings County are scant The amount of denitr1fication in deeper aquifers is undetermined, however, elevated concentratıons in deep aquifers as early as 1929 indicate some downward migration of nitrate from the water-table aquifer (Kımmel, 1972, p D202)

Veatch and others (1906) state that 8 of 13 private wells or pumping stations in Queens County sampled before 1903 had nitrate concentrations greater than $1 \mathrm{mg} / \mathrm{L}$ as $\mathrm{N}$ and as high as $34 \mathrm{mg} / \mathrm{L}$ Additional data on nitrate in Queens County are summarized in Soren (1971, table 1), which includes analyses of water from 38 wells (10 in the Lloyd aquifer, 15 in the Jameco-Magothy aquifer, and 13 in the upper glacial aquifer) that were sampled during the 1950's and 1960's Nitrate (as N) concentrations were above 10 $\mathrm{mg} / \mathrm{L}$ in water from only four of the wells, but many samples, including several from the Magothy aquifer, had concentrations higher than $02 \mathrm{mg} / \mathrm{L}$ (predevelopment level), which indicates some contamination in the upper glacial aquifer and local downward movement to the deeper aquifers These data indicate that nitrate contamınation in Queens County was not as advanced as Kings County

\section{RECENT HYDROLOGIC CONDITIONS (1983)}

Hydrologic data collected in 1983 indicate that the ground-water reservoir in eastern Queens County is still severely stressed The following paragraphs refer to maps and hydrogeologic sections that (1) represent the current three-dimensional distribution of hydraulic head, (2) indicate the patterns of ground-water movement, (3) define the distribution of ground-water qual1ty on western Long Island, and (4) quantify the effects of the stresses of urbanization on the ground-watersystem budget

\section{Water-Table and Potentiometric- Surface Altitudes}

Routıne water-level measurements made by USGS throughout Long Island are used to monitor changes in the ground-water reservoir that result from natural hydrologic fluctuations or contınued develop- ment by man Water-level measurements in 194 wells in Kings, Queens, and western Nassau County from January through April 1983 were used to construct a set of maps showing the configuration of the water table and the potentiometric surfaces in the confined aquifers of western Long Island (pl 3, 4, and 5) Table 8 (at end of report) lists all observation wells, their location by latitude-longitude, and their screened interval

Measurements were made in all avallable observation wells and industrial or public-supply wells that were not pumped durıng or immediately before the measurement period The distribution of these wells is summarized by aquifer and county in table 4 The deeper aquifers have fewer wells, especially in Kings County, primarily because installation expenses are greater, and many wells in Kings County, abandoned since the 1940's or earlier, have been destroyed

Table 4 Number of observations wells in which water levels were measured, January through April 1983

\begin{tabular}{|c|c|c|c|c|c|}
\hline \multirow[b]{2}{*}{ County } & \multicolumn{5}{|c|}{ Aquifer } \\
\hline & Upper glacıal & Jameco $^{1}$ & Magothy' & Lloyd & Total \\
\hline Kıngs & 31 & 2 & 0 & 1 & 34 \\
\hline Queens & 48 & 5 & 13 & 11 & 77 \\
\hline Nassau $^{2}$ & 53 & 1 & 21 & 8 & 83 \\
\hline Total & 132 & 8 & 34 & 20 & 194 \\
\hline
\end{tabular}

\footnotetext{
${ }^{1}$ The Jameco and Magothy aquifers are considered one hydrogeologic unit for purposes of mapping the distribution of hydraulic head

${ }^{2}$ That part of Nassau County adjacent to the Queens County border
}

Plates 3, 4, and 5 show the distribution of hydraulic head in the upper glacial (water table) aquifer, the Jameco-Magothy aquifer, and the Lloyd aquifer, respectively As described previously, the Jameco and Magothy aquifers are presented as one hydrogeo$\log 1 \mathrm{c}$ unit

Construction of these maps entalled overlaying maps of successive aquifers to verify that vertical gradients consistently represented the three-dimensional pattern of ground-water flow Hydrologic sections presented on plate 6 show the vertical distribution of head throughout the entire thickness of unconsolidated deposits Together, the sections and maps give an ind1cation of the three-dimensional distribution of hydraulic head throughout the ground-water system and the 
pattern of ground-water flow Most vertical gradients occur within confining units (except in the water-table aquifer near streams), enabling a set of maps and sections to be used effectively to represent three-dimensional flow patterns

Additional information on hydrologic factors that affect the distribution of hydraulıc head and movement of ground water within the system can be useful in constructıng such maps The location and average pumping rate during the measurement period of 103 industrial and public-supply wells are shown on plates 4 and 5, plate 6 shows the screened interval of each well on a cross section These data help define the configuration of the cones of depression that are centered at the screens of the pumping wells Other hydrogeo$\log 1 \mathrm{c}$ characteristics that affect the head distribution and are shown on these maps include (1) hydrogeologic-unit geometry, particularly the extent of confining layers, which affect vertical head relations and patterns of flow between aquifers, (2) locations of permeability boundaries, that is, the boundary between zones that differ considerably in hydraulic conductiv1ty, and (3) natural hydrologic boundaries such as gaining-stream channels and the saltwater-freshwater interface in the confined aquifers

\section{Water-Table Configuration}

The configuration of the water table in western Long Island, shown on plate 3, was constructed from water levels measured in 132 observation wells screened in the upper glacial aquifer (table 4) in March and April 1983 The water table shows anomalous mounds along the north shore The water level in well Q2791 in northeastern Queens was more than $50 \mathrm{ft}$ above sea level and has been comparably high in recent years These features are not perched ground water because they are hydraulically connected with the water table, as indicated by the fact that well Q2791 is screened from 11 to $19 \mathrm{ft}$ above sea level Rather, this mounding is attributed to two causes The first is that the upper glacial material on the north half of Long Island consists of moraine deposits that, on the average, have a hydraulic conductıvity 2 to 10 times lower than the outwash deposits on the south shore and locally could be several orders of magnitude lower This contrast in hydraulic conductivity is a major reason for the north-to-south asymmetry of the water table throughout Long Island The water-table divide is much closer to the northern shore than the southern shore throughout Kıngs and Queens Counties
The second reason for the anomalous high ground-water levels along the north shore is the configuration of the base of the water-table aquifer This aquifer is underlain by either bedrock or confinıng-unit material overlyıng bedrock, either of which forms a virtually impermeable bottom boundary to the aquifer at a shallow depth (fig 11) The Raritan confining unit is above sea level in northeast Queens, and bedrock crops out in northwest Queens (fig 11 and sections BB' and D-D' on pl 6), which further restricts groundwater discharge to the north shore and results in the steep northward gradients (pl 3)

Locations of 38 wells pumped for either industrial supply or public supply are shown on plate 3 Two major cones of depression caused primarily by pumping (during the measurement period) of $138 \mathrm{Mgal} / \mathrm{d}$ for public supply are evident in southern Queens County, where water levels have been drawn down to below sea level A considerable increase in gradıents from Nassau into Queens County since the predevelopment period indicates that the amount of ground water flowIng across the county line has increased significantly The western (smaller) cone of depression has no discharging wells at its center in the upper glacial aquifer Comparison of the water-table map with the potentiometric-surface map of the Jameco-Magothy aquifer (pl 4) indicates, however, that the larger cone of depression in the water table is caused by pumping in the JamecoMagothy aquifer This occurs in an area where the Gardıners Clay is absent and the aquifers have substantial hydraulic connection

\section{Potentıometric Surface of the Jameco- Magothy Aquifer}

The potentiometric-surface altitude in the Jameco-Magothy aquifer is shown on plate 4 Water levels measured in 42 wells screened in this aquifer in March and April 1983 were used to construct the map The number of avallable observation wells decreases westward rapidly in the area, only two are avallable in Kings County (table 4) Plate 4 also shows the northern extent of this aquifer unit and the Gardıners Clay (The Gardıners Clay, where present, separates the JamecoMagothy aquifer from the overlying upper glacial aquifer ) The Gardıners Clay overlaps the Jameco-Magothy aquifer throughout Kıngs County, thus, all ground water that moves vertically between the Jameco-Magothy and upper glacial aquifers must move through the confining unit In Queens County, the aquifer extends farther north, and the confining unit recedes southward 


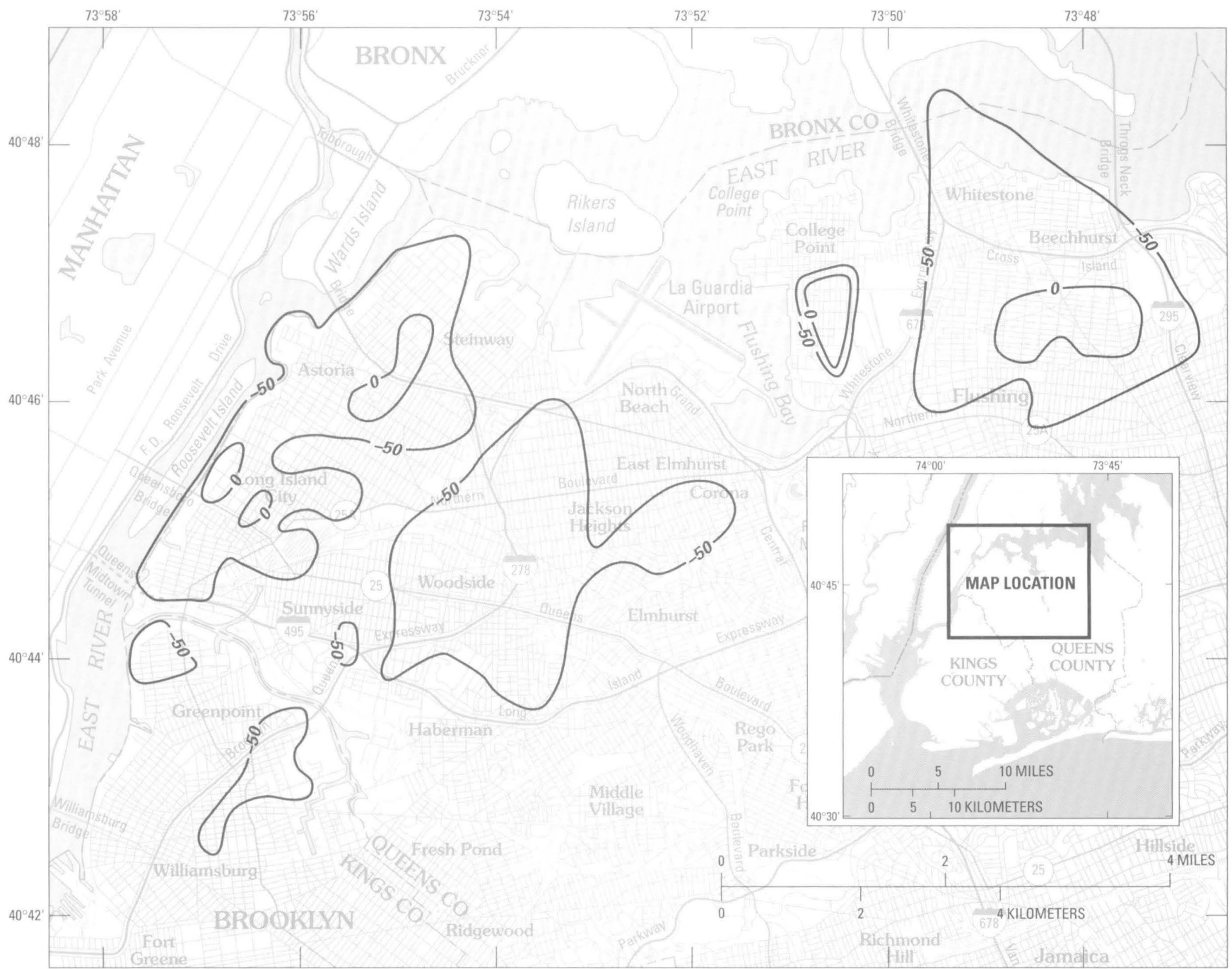

Base modified from U.S. Geological Survey, 1:100,000;

Long Island West, New York-New Jersey-Connecticut, 1984;

Newark, New Jersey-New York, 1986

Complete road network shown only in Kings and Queens Counties, New York

EXPLANATION

Line of equal surface altitude of low-permeability deposits-Contour interval 50 feet. Datum is sea level

Figure 11. Upper surface altitude of deposits with low permeability at base of water-table aquifer in northern Kings and Queens Counties.

In areas where the aquifer is not overlain by the Gardiners Clay, the Jameco-Magothy aquifer is in direct contact with the upper glacial aquifer.

Careful consideration was given to the extent of the confining unit in plotting the head relations between the Jameco-Magothy and upper glacial aquifers. Vertical head differences between the aquifers are greater, and flow rates lower, where the confining unit is present. The resulting distribution of head in both aquifers (pls. 3 and 4 ) indicates vertical gradients consistent with the three-dimensional patterns of groundwater flow. For example, ground-water gradients are downward beneath the water-table mound in northeast
Queens County, but to the east, under Alley Pond Creek, seepage to the creek results in upward gradients.

Head distribution in the Jameco-Magothy in Kings County indicates that water enters the aquifer vertically from the upper glacial aquifer by downward seepage through the Gardiners Clay and then flows southward to near the shore, where it discharges by upward seepage back through the Gardiners Clay.

Ground-water flow patterns in Queens County are more complex than in Kings County. A deep erosional channel through the Cretaceous deposits trends north-south through Queens County. (The origin of this channel is discussed in a previous section; a map of 
the configuration of the Cretaceous surface is shown in Smolensky and others, 1989) This channel also cuts through the Raritan confining unit and was subsequently filled with upper glacial deposits, which act as a conduit for ground-water flow between all aquifer units (sections C-C' and E-E', pl 6) The area in which these glacial deposits are laterally contiguous with the Jameco-Magothy aquifer is shaded on plate 4 to identify this pathway for ground-water flow, this is a significant factor in the three-dimensional pattern of groundwater movement in this area The Jameco-Magothy aquifer is underlain everywhere by the Raritan confining unit except in this eroded channel

Well Q2410 taps the eroded channel in northcentral Queens, it is screened in upper glacial deposits but at a depth equivalent to the Jameco-Magothy aquifer The hydraulic head in this well is similar to that in the overlying glacial deposits, which is consistent with the contention that the channel acts as a direct pathway for water from the upper glacial aquifer to pumping wells in the Jameco-Magothy aquifer

Pumping for public supply in the JamecoMagothy aquifer in Queens County during the measurement period was $3126 \mathrm{Mgal} / \mathrm{d}$, most pumping wells are in the east-central part of the county, and ground-water levels have been drawn down below sea level in an extensive cone of depression The Gardiners Clay is absent throughout most of this area, and the effects of pumping have propagated into the watertable aquifer ( $\mathrm{pl} \mathrm{3)}$ A concentration of pumping in southwestern Nassau County has drawn ground-water levels down to below sea level in that area

An important lateral hydrologic boundary in the Jameco-Magothy aquifer is the interface between fresh and saline ground water This interface is actually a zone of diffusion in which chloride concentrations increase from the typical concentration in the fresh ground-water system (less than $40 \mathrm{mg} / \mathrm{L}$ ) to that of seawater, about $19,000 \mathrm{mg} / \mathrm{L}$ Under undisturbed cond1tions, this zone of diffusion probably does not exceed several hundred feet in width, but nearby pumping can cause considerable mixing and expansion of this zone Chloride concentrations in water samples from wells near the shore were used as a guide to estimate the approximate position of the interface, results are discussed in greater detall in the section "Saltwater Intrus1on" (p 53)

The configuration of the saltwater-freshwater interface is controlled by the distribution of head within the ground-water system and tends toward an equilibnum state in which the pressures in saltwater and fresh- water balance The interface typically extends farther landward with increasing depth (pl 6) The interface in southern Kings and Queens extends several miles inland in the Jameco-Magothy aquifer Two holes in the Gardiners Clay along the south shore (pl 4) probably partly explain the extreme landward position of the interface in this part of the Jameco-Magothy aquifer Before development, these holes permitted discharge upward, lowering head in the Jameco-Magothy aquifer, durıng pumping, they provide a pathway for intrusion downward into the aquifer

The altitude of the base of the Jameco-Magothy aquifer at the edge of the interface ranges from 300 to $600 \mathrm{ft}$ below sea level across southwestern Long Island Freshwater heads of 75 to $15 \mathrm{ft}$ are required to balance static saline ground water at these depths Hydraulic heads along the edge of the freshwater system range

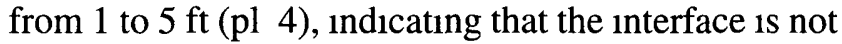
in an equilibrium position and is moving landward

Water levels at several wells in southwestern Nassau County have been below sea level (fig 12) and are depicted as a separate cone of depression in several published potentiometric-surface maps of the Magothy aquifer This area has no known stress that could cause such a local cone of depression, however An inspection of recent water-quality analyses shows that the dissolved-solids concentrations at these wells are elevated by sea water and are high enough to significantly increase the density of water in the well This would cause the measured hydraulic head to be lower than if freshwater were in the well casing Thus, the observed depressions in this area do not indicate converging flow patterns, but are rather an artifact of pressure-head measurement in terms of a fluid that is denser than freshwater

Evaluation of horizontal gradients and flow rates in a system of dilute seawater such as this require adjustment of head measurements to the calculated head of a common fluid (freshwater) These head data are referred to as freshwater or equivalent-freshwater head The equation for freshwater head $\left(h_{f}\right)$ is given as

$$
h_{f}=\left(h_{s}-z\right) \frac{\rho_{s}}{\rho_{f}}+z
$$

where $\quad h_{s}$ is measured head of saline ground water,

$\rho_{s}$ is density of salıne ground water,

$\rho_{f}$ is density of fresh ground water, and

$z$ is altitude of the well screen 


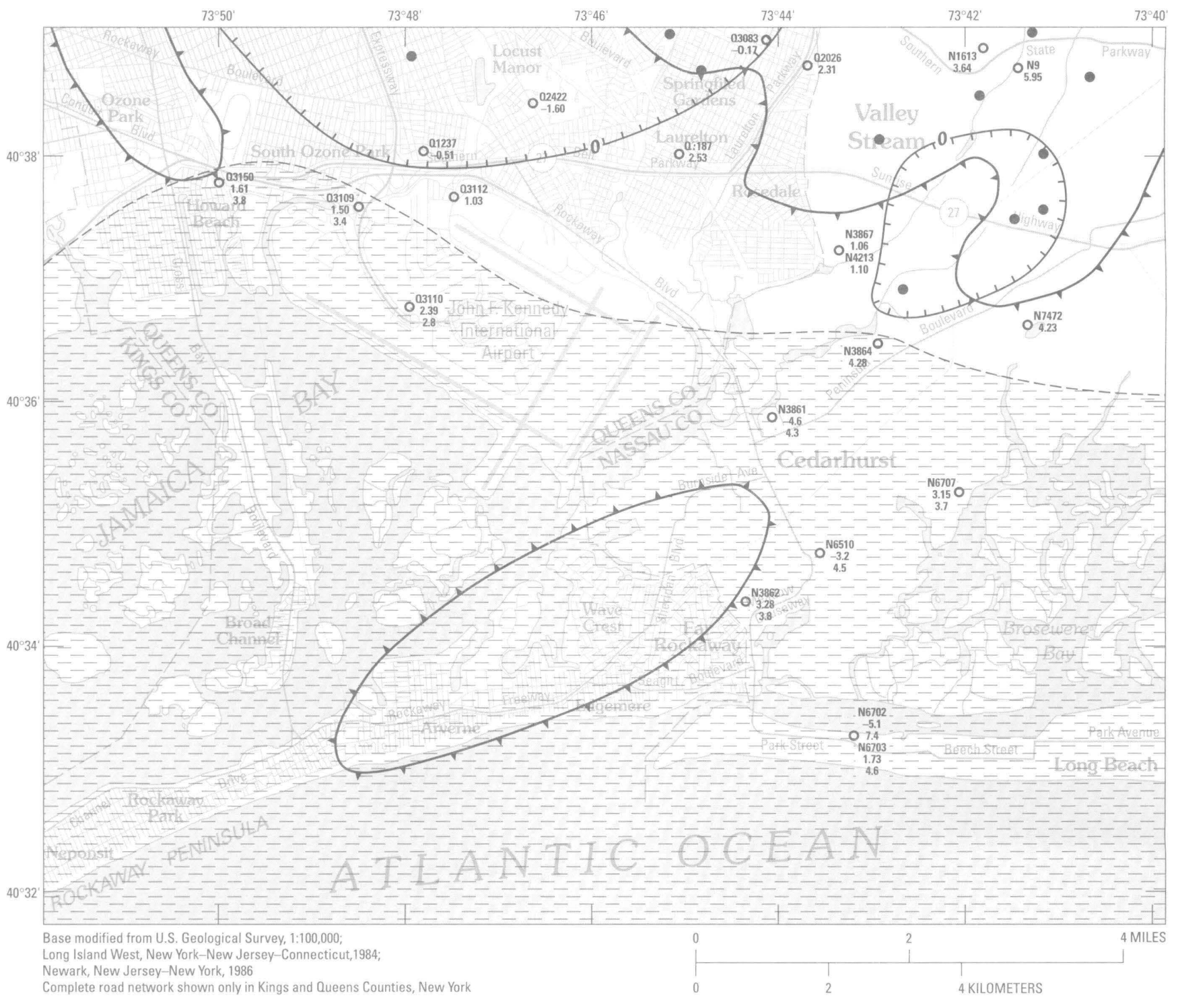

\section{EXPLANATION}
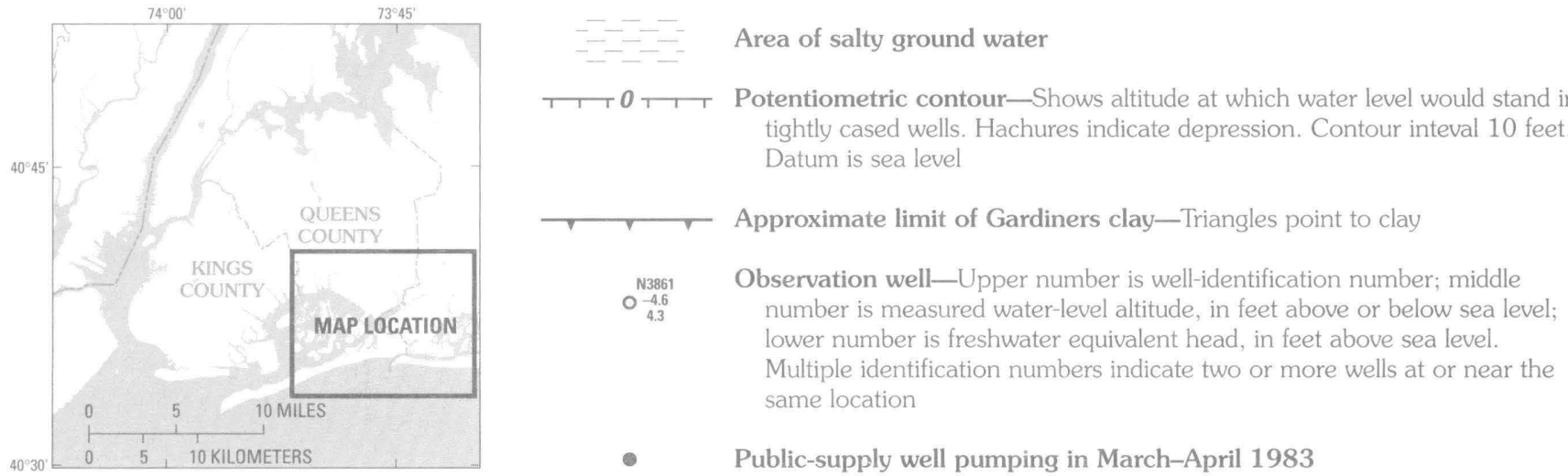

- $\quad$ Public-supply well pumping in March-April 1983

Figure 12. Distribution of hydraulic head in southern Queens and southwestern Nassau County, as measured and converted to freshwater equivalent head. 
The density of the water in the casing (the measurment fluid) was estımated assuming a proportional mixture of freshwater and seawater determined by the measured chlonde concentration The chlonde concentration, estimated density, and freshwater and saltwater heads, in pertınent wells are presented in table 5 Corrections to freshwater head resulted in changes of as much as $12 \mathrm{ft}$ (well N6702) The distribution of head in wells in southern Queens and southwestern Nassau County, both as actually measured and as equivalentfreshwater head, is shown in figure 12 The measured heads in wells N3861, N6510, and N6702 were below sea level as a result of saline water in the well casings The distribution of equivalent freshwater head does not show a cone of depression Hydraulic gradients in freshwater head indicate a landward movement of ground water toward pumping centers to the north

Ground-water levels shown on plates 3, 4, and 5 were made as part of an 1slandwide synoptic measurement, water samples were not collected at the time of measurement Estımates of fluid density were made from chlonde concentrations in the most recent sampling of these wells, the dates of these analyses are included in table 5 A more accurate estımate of the effects of local differences in fluid density would be possible if sampling and chemical analyses were included with future water-level measurements Thus, if a well is expected to be affected by saltwater, it would first be pumped to ensure that the water in the casing is indicative of the local ground water, then a sample would be taken for chemical analysis, and finally the recorded static water level would be measured

The rate of movement of the saltwater-freshwater interface is difficult to estımate To obtain an approximation, Darcy's law was applied along a transect trending from the center of Jamaica Bay northnortheastward toward the center of pumping Estimates of the horizontal component of velocity based on published values of water-transmittıng coefficients ranged from 05 to $10 \mathrm{ft} / \mathrm{d}$ Although this rate may seem slow, at a rate of $10 \mathrm{ft} / \mathrm{d}$, the interface would advance $1 \mathrm{mi}$ in 15 years, a distance of major consequence to long-range resource management, especially because intrusion could be more rapid near well screens or in local zones with high permeability and,or low porosity

Table 5. Equivalent freshwater head at wells affected by salıne water in the Jameco-Magothy aquifer [Well locations are shown in figure 12]

\begin{tabular}{|c|c|c|c|c|c|c|}
\hline Well number & $\begin{array}{l}\text { Date of } \\
\text { sample } \\
\text { collection }\end{array}$ & $\begin{array}{l}\text { Average } \\
\text { screen altitude } \\
\text { (feet below } \\
\text { sea level) }\end{array}$ & $\begin{array}{c}\text { Chloride } \\
\text { concentratıon } \\
\text { (millıgrams } \\
\text { per liter) }\end{array}$ & $\begin{array}{c}\text { Densıty' } \\
\text { (grams per } \\
\text { cubıc centımeter) }\end{array}$ & $\begin{array}{l}\text { Saltwater head } \\
\text { (feet above or } \\
\text { below sea level) }\end{array}$ & $\begin{array}{c}\text { Freshwater head } \\
\text { (feet above sea level) }\end{array}$ \\
\hline N6073 & $10 / 5 / 83$ & -460 & 5,800 & 10061 & 17 & 46 \\
\hline N6702 & $8 / 6 / 81$ & -672 & 15,000 & 10187 & -51 & 74 \\
\hline N6510 & $4 / 10 / 62$ & -447 & 14,000 & 10173 & -32 & 45 \\
\hline N3861 & $9 / 1 / 81$ & -517 & 14,000 & 10173 & -46 & 43 \\
\hline N6707 & $9 / 28 / 83$ & -492 & 1,900 & 10010 & 32 & 37 \\
\hline N3862 & $8 / 26 / 81$ & -294 & 1,900 & 10010 & 33 & 36 \\
\hline Q3110 & $7 / 18 / 83$ & -306 & 2,300 & 10014 & 24 & 28 \\
\hline Q3109 & $8 / 18 / 83$ & -278 & 6,400 & 10069 & 15 & 34 \\
\hline Q3150 & $6 / 21 / 83$ & -119 & 15,000 & 10187 & 16 & 38 \\
\hline
\end{tabular}

\footnotetext{
${ }^{1}$ Estımated from a relation between chlonde concentration and density in dilute seawater solutions (Weast,1981, p D229)
} 


\section{Potentiometric Surface of the Lloyd Aquifer}

The potentiometric-surface altitude of the Lloyd aquifer measured in January 1983 is shown on plate 5 Only 20 wells that tap the Lloyd aquifer were avarlable for measurement, and only one is in Kings County The Raritan confining unit overlaps the Lloyd aquifer throughout Kings and western Queens In central Queens, where the ancestral Hudson River channel eroded the Raritan confining unit away (shaded on pl 5), upper glacial sedıments lie either directly on bedrock or on deposits of the Lloyd aquifer and thus afford a direct pathway for ground-water exchange among all three aquifers

The potentiometric-surface map ( $\mathrm{pl} \mathrm{5)} \mathrm{shows}$ four public-supply wells, all in Queens County, that tap the Lloyd aquifer Together they pumped at a rate of $594 \mathrm{Mgal} / \mathrm{d}$ durnng the measurement penod The cone of depression created by these wells is deeper and more extensive than that in the overlying Jameco-Magothy aquifer (pl 4), where pumping is more than six times greater No observation wells are near the center of the cone of depression, thus, the shape of the potentiometric surface near these wells is only estimated Water levels measured in the pumping wells after they had been temporarily shut down for several hours were still more than $20 \mathrm{ft}$ below sea level Although these data are difficult to interpret and are not used to indicate absolute head values, they are considered to indicate the maxımum ground-water level in an area immediately surrounding the pumping wells during their operation

The configuration of the potentiometric surface near the eroded channel indicates that water flows downward through the channel-fill deposits from the overlying aquifers to recharge the Lloyd aquifer Head contours in the Lloyd aquifer indicate that water is diverging from this source area

The Lloyd aquifer is expected to be more sens1tive to pumping than the overlying aquifers for two reasons First, probably only about 5 percent of the total volume of water in the system moves through the Lloyd because it is the deepest aquifer and is almost everywhere separated from the rest of the system by the Raritan confining unit Second, even though pumping in the Lloyd aquifer would increase the downward hydraulic gradients between the overlying JamecoMagothy aquifer and the Lloyd aquifer and would increase the downward flow of water into the Lloyd, the considerable pumping in the overlying aquifer has caused a significant drawdown in that aquifer, thus, even a small amount of pumping from the Lloyd would lower the hydraulic head to below that in the overlying aquifer The result is that any pumping causes a more extensive and deeper cone of depression in the Lloyd aquifer than in the overlying aquifer, as seen through comparison of plates 4 and 5

Pumping for public supply from the Lloyd aquifer occurs at two locations in Nassau County, near the Queens County line One is near the north shore, where the Lloyd aquifer is fairly close to land surface, the other is at Long Beach on the south-shore barrier island, where it is the only source of fresh ground water

The saltwater-freshwater interface in the Lloyd aquifer is estımated to lie just off the south shore (pl 5) Here the base of the Lloyd ranges from 600 to $1,200 \mathrm{ft}$ below sea level Freshwater heads of 15 to $30 \mathrm{ft}$ would be needed to balance static seawater at these depths, but water-level measurements along the interface indicate that head in the Lloyd aquifer does not exceed a few feet Thus, data indicate that, as in the overlying Jameco-Magothy aquifer, the interface is not in an equilibrium position and is moving landward

Darcy's Law was used to estımate the rate of landward movement on a transect due north through the center of Jamaica Bay (pl 5) Estımates of the hor1zontal velocity are from 002 to $005 \mathrm{ft} / \mathrm{d}$-much lower than in the overlying Jameco-Magothy aquifer and consistent with the smaller ground-water gradients observed in the Lloyd (pl 4,5)

\section{Distribution of Hydraulic Head Along Selected Vertical Sections}

The five hydrogeologic sections shown on plate 6 depict the vertical variations in hydraulic head within the system All pumpıng wells and observation wells that lie along or close to the sections are indicated with their screened intervals, the observed head values shown are considered the average head over the screened interval Equipotential lines are near vertical in each aquifer unit, where ground-water gradients are generally horizontal, but refract toward the horizontal where they enter the confining units because here, the vertical gradients are much larger than in the aquifers

In the interpretation of head maps (plan view), ground-water flow paths are assumed to be aligned with the direction of the steepest hydraulic gradient In the interpretation of hydrologic sections, however, this is not always true In vertical sections, flowlines generally are not perpendicular to equipotential lines 
because the aquifer units are anisotropic, and the section is drawn with extreme vertical exaggeration

The estımated configuration of the saltwaterfreshwater interface is also indicated, it typically extends landward with depth and is near vertical within confining layers It could contain more irregularities than are shown as a result of extensive clay lenses within the aquifer units or local drawdown from pumping

Section A-A' (pl 6) trends north-south in Kings County The water table along this profile is asymmetric because the ground-water divide is close to the north shore The water-table mound at the divide is probably caused by a local zone of low permeability in the moraine deposits Low head in the Jameco-Magothy aquifer, caused by pumping in Queens County, has caused the salt-water-freshwater interface in this aquifer to move inland As a result, subsea discharge upward through the Gardıners Clay has probably ceased

Freshwater in the Lloyd aquifer extends considerably farther seaward than in the Jameco-Magothy, but, as stated previously, head in the freshwater system is inadequate to balance sea water at the depths of the Lloyd aquifer Thus, salıne ground water in the Lloyd probably is moving slowly landward

Section B-B' (pl 6) trends from northwestern Queens County southward to near the Kıngs-Queens County line The extreme thinnıng of the upper glacial aquifer at the north shore is evident in the section Withın the north-central part of the section is a large area in which the bedrock is overlain by confining-unit material, as a result, the bottom boundary of the aquifer system is less than $50 \mathrm{ft}$ below sea level locally This is considered a major cause of high ground-water levels along the north shore

Freshwater in the Jameco-Magothy aquifer is limited along this section The hole in the over-lying Gardıners Clay, which is evident in this section, provides a pathway for intrusion of salıne ground water Ground water in the Lloyd aquifer at section B-B' flows generally eastward toward the major pumping center

Section C-C' (pl 6) trends southward from Flushing Bay and crosses the ancestral Hudson River channel, which has eroded through all Cretaceous deposits and forms a pathway for water to the Lloyd aquifer from above Water at well Q2418 has attained a chlonde concentration as high as $550 \mathrm{mg} / \mathrm{L}$ (1981), which may indicate that saltwater from Flushıng Bay and its estuary was drawn into the ground-water system, possibly by intensive pumping during the 1964-65 World's Fair or from public-supply wells screened in the Jameco-Magothy and Lloyd aquifers to the south The latter possibility warrants concern for potential saltwater intrusion from the north shore toward the major pumping centers in central Queens

Section D-D' (pl 6) trends north-south near the Queens-Nassau County border Only small traces of the Jameco Gravel have been found this far east This section indicates that the high pumping rates in southeastern Queens County have caused landward grad1ents in the Lloyd and Jameco-Magothy aquifers Flow in small zones along the north and south shores in the upper glacial aquifer is seaward, though

Salıne ground water probably is migratıng downward into the Lloyd aquifer from the overlying JamecoMagothy aquifers Darcy's Law for fluids of variable density was used with data from wells N6703 and N8011 to estımate the vertical velocity and traveltıme for salıne ground water to cross the Raritan confining unit Darcy's Law is given as

$$
V_{z}=-\frac{k_{z}}{n \mu}\left(\frac{\Delta P}{\Delta Z}+\rho g\right)
$$

where $V_{z}$ is vertical velocity component,

$k_{\mathrm{z}} \quad$ is vertical intrinsic permeability,

$n \quad 1$ porosity,

$\mu \quad 1$ v viscosity,

$\Delta P \quad$ is change in pressure across the confining unit,

$\rho \quad$ is density, and

$\Delta Z \quad$ is thickness of confining unit, and

$g \quad$ is the gravitational constant

Conservative values for aquifer properties were assumed, including $n=02$, and $k_{\mathrm{z}}$ is calculated from a vertical hydraulic conductivity of $0002 \mathrm{ft} / \mathrm{d}$ for freshwater A density of $1019 \mathrm{~g} / \mathrm{cm}^{3}$ was used for ground water overlying the Raritan confining unit The resulting velocity was about $02 \mathrm{ft} / \mathrm{yr}$, and the traveltıme across the confining unit was about 1,250 years This indicates that lateral intrusion of saltwater within the Lloyd aquifer poses a greater threat than intrusion from the overlying aquifer

Section E-E' (pl 6) runs east-west through Kings and Queens Counties This section shows the severe effects of pumping in Queens County Large westward gradients indicate movement of ground water from Nassau County into Queens and downward into the Lloyd aquifer The vertical pathway for water 
to the Lloyd aquifer through the ancestral Hudson River channel is also evident in this section Sections D-D' and E-E' show a larger cone of depression in the Lloyd than in the over-lying aquifers despite the lower pumpage

\section{Water Budget}

Even though much of the ground-water system in Kings County is recoverıng from previous stress, and water levels now approach those of 1903, some severe, perhaps irreversible, deviations from the predevelopment flow patterns persist Under predevelopment conditions, ground water was replenished entirely by recharge from precipitation and discharged solely by seepage to streams and as subsea outflow to the surrounding saltwater bodies Urbanization and pumping have altered recharge and discharge patterns and introduced new components to the water budget The est1mated quantities of inflow and outflow in 1983 are compared with predevelopment values in table 6 The water budget was developed through evaluation of hydrologic data and through calıbration of a threedimensional ground-water flow model of the Long Island ground-water system $(\mathrm{H} \mathrm{T}$ Buxton and D A Smolensky, U S Geological Survey, written commun , 1988), which was being developed concurrently with this project

\section{Inflow}

The large expanses of paved, 1mpervious surfaces in Kings and Queens Counties have caused

Table 6 Water budgets for predevelopment and recent (1983) conditıons [Values are in million gallons per day]

\begin{tabular}{|c|c|c|}
\hline Budget component & $\begin{array}{c}\text { Predevelopment } \\
\text { (pre-1900) conditions }\end{array}$ & $\begin{array}{l}\text { Recent (1983) } \\
\text { conditions }\end{array}$ \\
\hline \multicolumn{3}{|l|}{ Inflow } \\
\hline Recharge from precipitation & 209 & 107 \\
\hline Leakage from water-supply lines and other infiltration & 0 & 70 \\
\hline Ground-water inflow from Nassau County & 6 & 9 \\
\hline Total & 215 & 186 \\
\hline \multicolumn{3}{|l|}{ Outflow } \\
\hline Base flow to streams & 62 & 11 \\
\hline \multicolumn{3}{|l|}{ Pumpage } \\
\hline Public supply & 0 & 57 \\
\hline Private (net) & 0 & 17 \\
\hline Subsea discharge & 153 & 101 \\
\hline Total & 215 & 186 \\
\hline
\end{tabular}

increased runoff and evaporation, which in turn have led to a major reduction in recharge from precipitation Analysis of land use in Kings and Queens by the City of New York (New York City Department of Environmental Protection, 1979) indicates that Kings County has been the most severely affected by development and that Queens, although also affected, still has areas of permeable land surface such as parks, cemetenes, and low-density residential communities About 15 percent of precipitation, $24 \mathrm{Mgal} / \mathrm{d}$ countywide or 032 (Mgal/d)/mi ${ }^{2}$ in Kings County, and about 35 percent of precipitation, $83 \mathrm{Mgal} / \mathrm{d}$ countywide or $073(\mathrm{Mgal} / \mathrm{d}) /$ $\mathrm{ml}^{2}$ in Queens County, is estımated to enter the groundwater system as recharge, a considerable decrease from that which reached the aquifers before development, $11(\mathrm{Mgal} / \mathrm{d}) / \mathrm{m}^{2}$ (table 6) Recharge in neighboring Nassau County contınues to equal about 50 percent of precipitation, even under present urban conditions, because an extensive recharge-basin system captures runoff and returns it to the ground

A large volume of water is returned or added to the ground-water system as leakage from artificial structures, which include water-supply lines and sewer lines, and as infiltration of water used for purposes such as lawn sprinkling In areas where the water was pumped from the ground, such infiltration would constitute only a partial return to the system In 1983, 57 $\mathrm{Mgal} / \mathrm{d}$ of water was pumped from local aquifers to supply about 500,000 people and 7,600 commercial and industrial users in southeastern Queens All of Kings County and most of Queens County are supplied with water totaling almost $700 \mathrm{Mgal} / \mathrm{d}$ from upstate surface-water reservoirs, however (New York City

Bureau of Water Supply, written commun, 1983) Infiltration of water leaking from this source constitutes artificial recharge from an external and potable source In all, a total of about $760 \mathrm{Mgal} / \mathrm{d}(450 \mathrm{Mgal} / \mathrm{d}$ in Kıngs and $310 \mathrm{Mgal} / \mathrm{d}$ in Queens) is transmitted through the water-supply system, which contains $4,270 \mathrm{mi}$ of supply lines (1,900 mi in Kings County and 2,370 $\mathrm{mi}$ in Queens) and has 613,000 service connections (313,000 in Kıngs County and 300,000 in Queens) (New York City Department of Environmental Protectıon, 1981, and Jamaica Water Supply Co, oral commun, 1984) Although 
many water-main breaks are tabulated annually by the New York City Bureau of Water Supply, constant leaking of the aging water-supply system is the largest source of recharge from artıficial sources

The total volume of leakage from artıficial sources is difficult to estımate but undoubtedly const1tutes a major part of the present ground-water budget The total rate of infiltration from these sources is est1mated to be about $70 \mathrm{Mgal} / \mathrm{d}$, although it could be larger The distribution of this recharge corresponds to water-supply and sewer networks About $30 \mathrm{Mgal} / \mathrm{d}$ is estimated to infiltrate in Kings and $40 \mathrm{Mgal} / \mathrm{d}$ in Queens

The final component of inflow to western Long Island is ground-water flow from Nassau County Large hydraulic gradients in all aquifer units indicate that a significant amount of water enters from Queens County as subsurface flow A flow-model analysis indicated that about $9 \mathrm{Mgal} / \mathrm{d}$ of ground water flows across the Nassau-Queens border, a 50-percent increase from pre-development conditions as a result of the steeper gradients induced by current pumping rates

Total inflow to the western Long Island groundwater system from the above sources is $186 \mathrm{Mgal} / \mathrm{d}$ This is less than the total amount of water enternng before development Even the significant inflow from leakage of imported surface water is insufficient to compensate for the loss of natural recharge through urbanization

\section{Outflow}

Water is discharged from the ground-water system in three ways-as stream base flow, through pumpage, and as subsea outflow Under predevelopment conditions, base flow constituted a significant outflow from the ground-water system Today, however, only two major streams remain in Kings and Queens (Flushing Creek and Alley Creek) These, along with several smaller creeks, receive a total of about $11 \mathrm{Mgal} / \mathrm{d}$ in ground-water seepage (base flow)

As stated earlier, ground water that is pumped and either lost by evaporation or discharged to the sea is considered consumptive (net) pumpage and represents a net draft on the ground-water system In 1983, pumpage for public supply from Queens aquifers was $57 \mathrm{Mgal} / \mathrm{d}$ Of the $57 \mathrm{Mgal} / \mathrm{d}$ of public-supply pumpage in Queens County, $118 \mathrm{Mgal} / \mathrm{d}$ was pumped from the upper glacial aquifer, $393 \mathrm{Mgal} / \mathrm{d}$ from the Jameco-Magothy aquifer (35 Mgal/d from the Magothy aquifer and $43 \mathrm{Mgal} / \mathrm{d}$ from the Jameco aquifer), and $59 \mathrm{Mgal} / \mathrm{d}$ from the Lloyd aquifer (Jamaica Water Supply Company, written commun , 1984)

Private pumping includes pumping for industrial purposes and for dewatering in areas of ground-water flooding The water pumped for these purposes is discharged to sewers with ocean outfall and is assumed consumptive Net industrial pumpage in 1983 is est1mated to have been $23 \mathrm{Mgal} / \mathrm{d}$ in Queens and 66 $\mathrm{Mgal} / \mathrm{d}$ in Kings (New York State Department of Env1ronmental Conservation, written commun , 1984) In 1983, subway dewatering in the Flatbush area of Kings County averaged $4 \mathrm{Mgal} / \mathrm{d}$ (New York City Transit Authority, oral commun , 1984) Fourteen additional wells with a maximum pumping capacity of $20 \mathrm{Mgal} / \mathrm{d}$ are planned in the East New York and Bedford sections of Kings County (New York City Transit Authority, oral commun , 1985) Undoubtedly homes, businesses, and institutions are dewatering also Temporary dewatering is often required for the construction of underground structures, but no information is currently avallable A total of about $8 \mathrm{Mgal} / \mathrm{d}$ is pumped for dewatering purposes in western Long Island (6 Mgal/d in Kings and $2 \mathrm{Mgal} / \mathrm{d}$ in Queens) (New York City Department of Environmental Protection, oral commun , 1984) Therefore, a total of about $17 \mathrm{Mgal} / \mathrm{d}$ is pumped for private purposes in Kings and Queens Counties

The remainıng discharge component of the ground-water budget, subsea outflow to the surrounding saltwater bodies, is considerably smaller than under predevelopment conditions but is still the largest discharge component Because subsea discharge is impossible to measure, it is typically estimated as the flow rate required to balance the ground-water budget Subsea outflow from the upper glacial and Jameco-Magothy aquifers at present is estımated to be $101 \mathrm{Mgal} / \mathrm{d}$, this value is corroborated by ground-water-flow model analysis (H T Buxton and D A Smolensky, U S Geological Survey, written commun 1988) Subsea outflow from the Lloyd is negligible because pumping has lowered hydraulic heads throughout that aquifer in Kings and Queens, producing landward gradients

\section{Ground-Water Quality}

The present quality of the ground water of western Long Island has been affected by more than 200 years of development and urbanization The natural quality of Long Island's ground water (before man's influence) was the product of chemical constituents 
introduced with recharge from precipitation and natural geochemical reactions that occur between the ground water and the aquifer material Present groundwater quality is affected further by contaminants introduced by human activities as well as by additional geochemical reactions

This study used the results of analyses of ground-water samples collected in 1983 to describe the present quality of ground water on western Long Island An earlier, prelımınary study by Buxton and others (1981) used results from a network of 77 observation wells supplemented by concurrent data from 67 public-supply wells provided by the Jamaica Water Supply Company These samples were collected in 1981 In 1983, the network of observation wells sampled by the USGS was expanded to 107 wells (locations are shown on pl 7) Samples were collected from June through October 1983, results are presented in table 10 (at end of report, 1981 data are included where avallable) Concurrent data from 84 public-supply wells sampled during 1983 and analyzed by the Jamaica Water Supply Company are presented in table 11 (at end of report)

Chloride and nitrate concentration data are used to indicate the extent to which contamination from land surface and saltwater intrusion has propagated within the ground-water system A brief summary of the distribution of other major inorganic constituents is provided in support of this analysis In addition,

concentrations of selected organic compounds detected in public-supply wells of the Jamaica Water Supply Company are used to indicate the effect of these chemicals and related human activities on the ground-water system

\section{Extent of Human-Induced Contamınation}

In the following discussion, maps and vertical sections are used to provide a three-dimensional representation of (1) the extent to which land-surface contamination has migrated through the ground-water system, and (2) the extent to which the saltwater-freshwater interface has moved landward in all three major aquifers Chloride and nitrate are used as indicators as described in the section "Deterioration of ground-water quality" (p 29) Background concentrations of both are low, less than $10 \mathrm{mg} / \mathrm{L}$ and $02 \mathrm{mg} / \mathrm{L}$ as $\mathrm{N}$, respectively, compared to concentrations observed in 1983 The maps (figs 13-15, p 46-51) and cross sections (fig 16, p 52) can be evaluated in conjunction with the corresponding potentiometric maps (pl 3,4, and 5) and hydrogeologic sections (pl 6), to indicate the extent of contamination in relation to the patterns of groundwater movement

\section{Contamınatıon from Land Surface}

Nitrogen, in the form of nitrate, was one of the first contaminants to be introduced to the ground-water system, it entered as fertılizers and domestic waste dissolved in natural recharge Even today, nitrate contınues to enter the system through leakage from New York City's extensive combined-sewer network (Kımmel, 1972)

The shaded areas on the sections in figure 16 indicate the extent of ground water that has been affected by contamination from land surface This area is defined on the assumption that nitrate has entered the system at the water table uniformly and consistently over the years and has migrated along natural groundwater flow paths through the system Only three wells in the shaded area (Q2978, section D-D', Q2418, section C-C', and Q2137, section E-E') had nitrate concentrations less than $10 \mathrm{mg} / \mathrm{L}$, and Q2418, one of these wells, is affected by seawater intrusion This format is used to indicate areas with a high expectation of contamınation from land-surface sources and to provide a means to assess further migration of contaminated ground water

Nitrate concentrations throughout the upper glacial aquifer indicate severe contamination that appears to decrease eastward (figs 13B and 16) Concentrations in 19 of 35 samples from Kings County exceeded the public health standard of $10 \mathrm{mg} / \mathrm{L}$, and concentrations in 27 of the 35 samples were greater than $5 \mathrm{mg} / \mathrm{L}$ (as N) In Queens County, 8 of 39 samples had concentrations greater than $10 \mathrm{mg} / \mathrm{L}$ (as $\mathrm{N}$ ), and 24 exceeded $5 \mathrm{mg} / \mathrm{L}$ (as N) Of 11 samples from Nassau County, only 1 exceeded the public health standard, but 8 had concentrations of $37 \mathrm{mg} / \mathrm{L}$ (as $\mathrm{N}$ ) or higher

Nitrate concentrations in samples from only 2 of 72 wells in the Jameco-Magothy aquifer were greater than $10 \mathrm{mg} / \mathrm{L}$ (as N) The distribution of these values 1s plotted in figure 14B (p 49) Of 69 samples from wells in Queens and Nassau Counties that were not affected by seawater, 12 were from wells in the area where the Gardıners Clay separates the Jameco-Magothy and upper glacial aquifers The highest nitrate concentration in these wells was $079 \mathrm{mg} / \mathrm{L}$, and all but two wells had concentrations of $028 \mathrm{mg} / \mathrm{L}$ or less Of the 47 samples taken from inland wells where the Gar- 


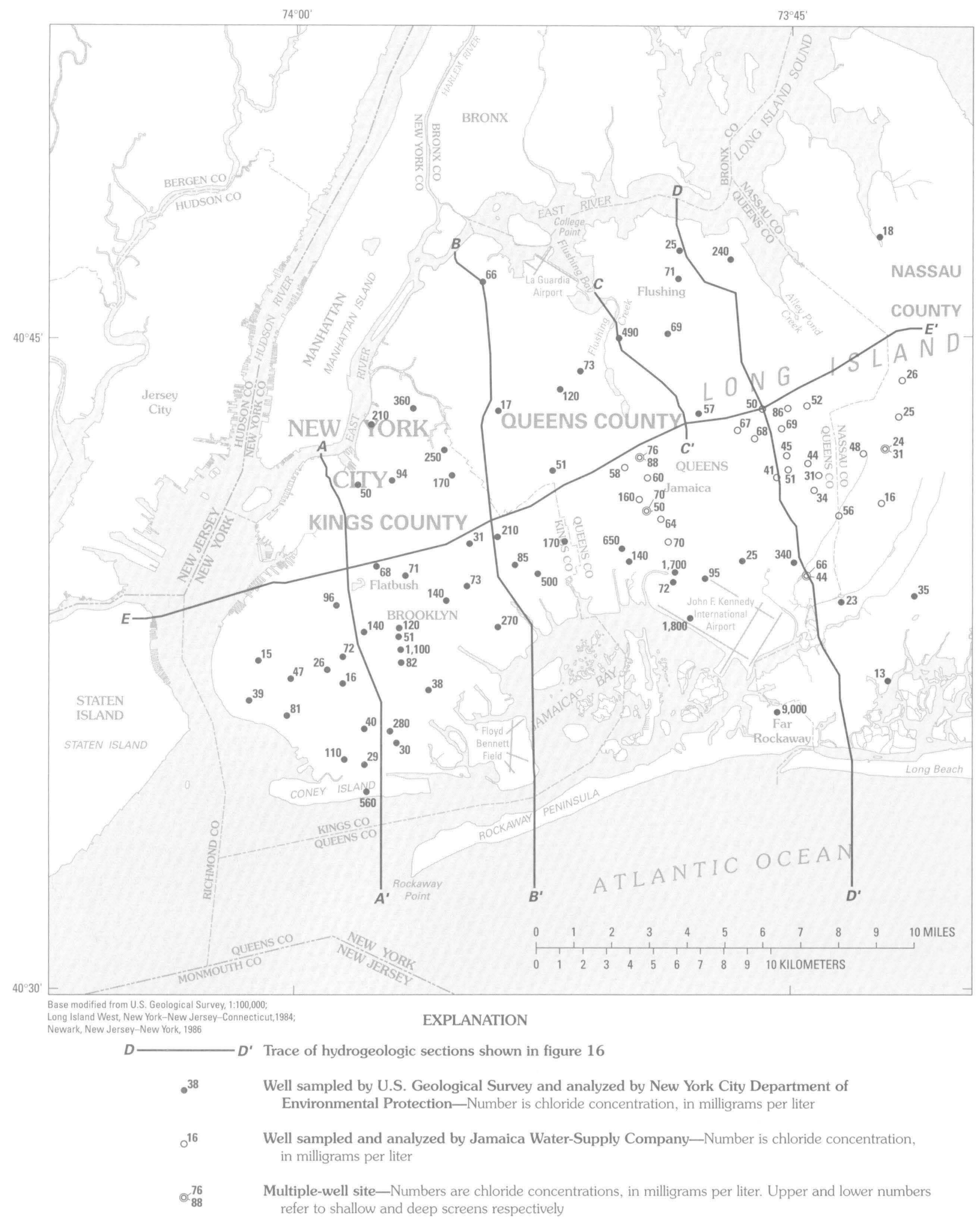

Figure 13A. Chloride concentrations in the upper glacial aquifer, 1983. 


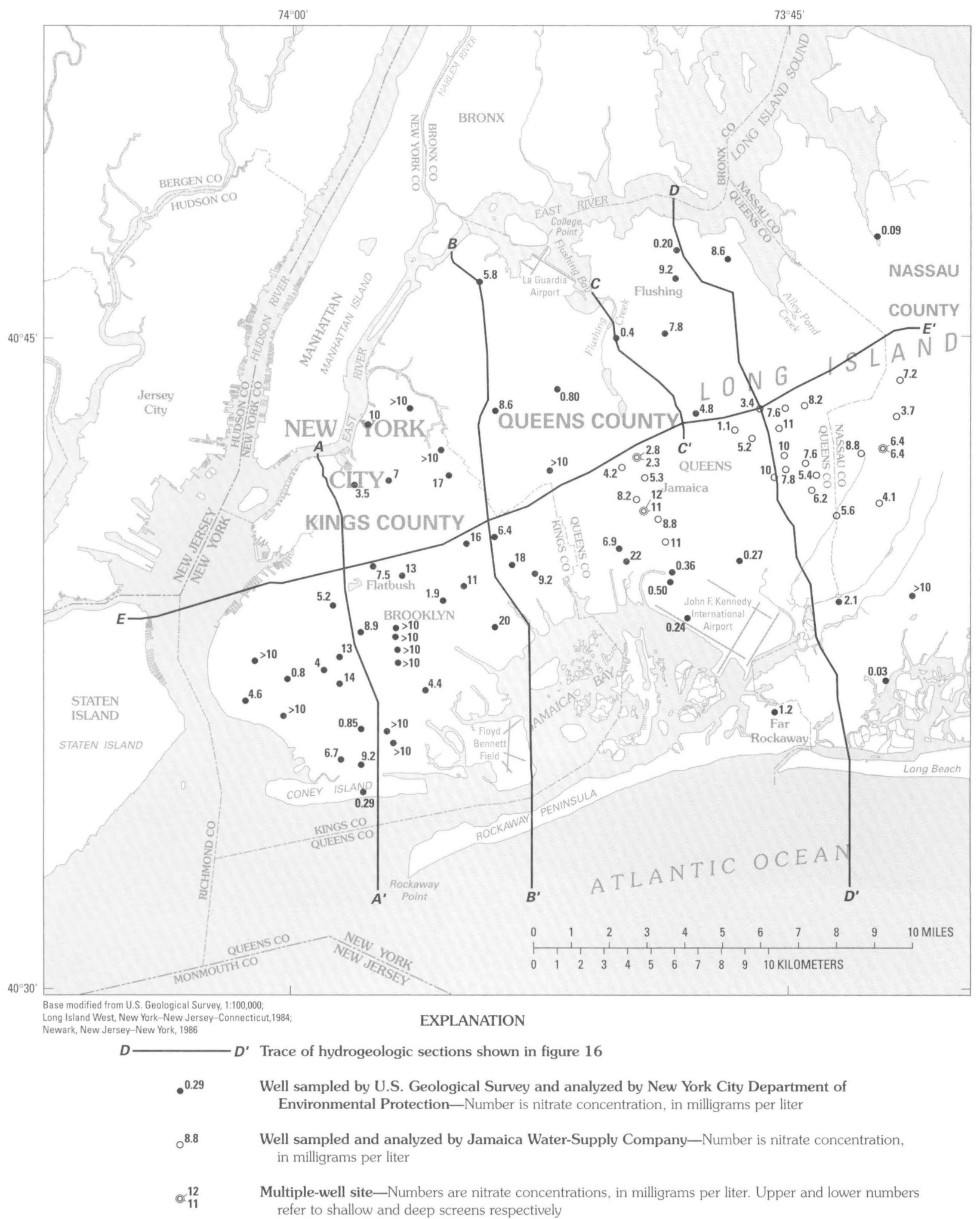

Figure 13B. Nitrate concentrations in the upper glacial aquifer, 1983. 


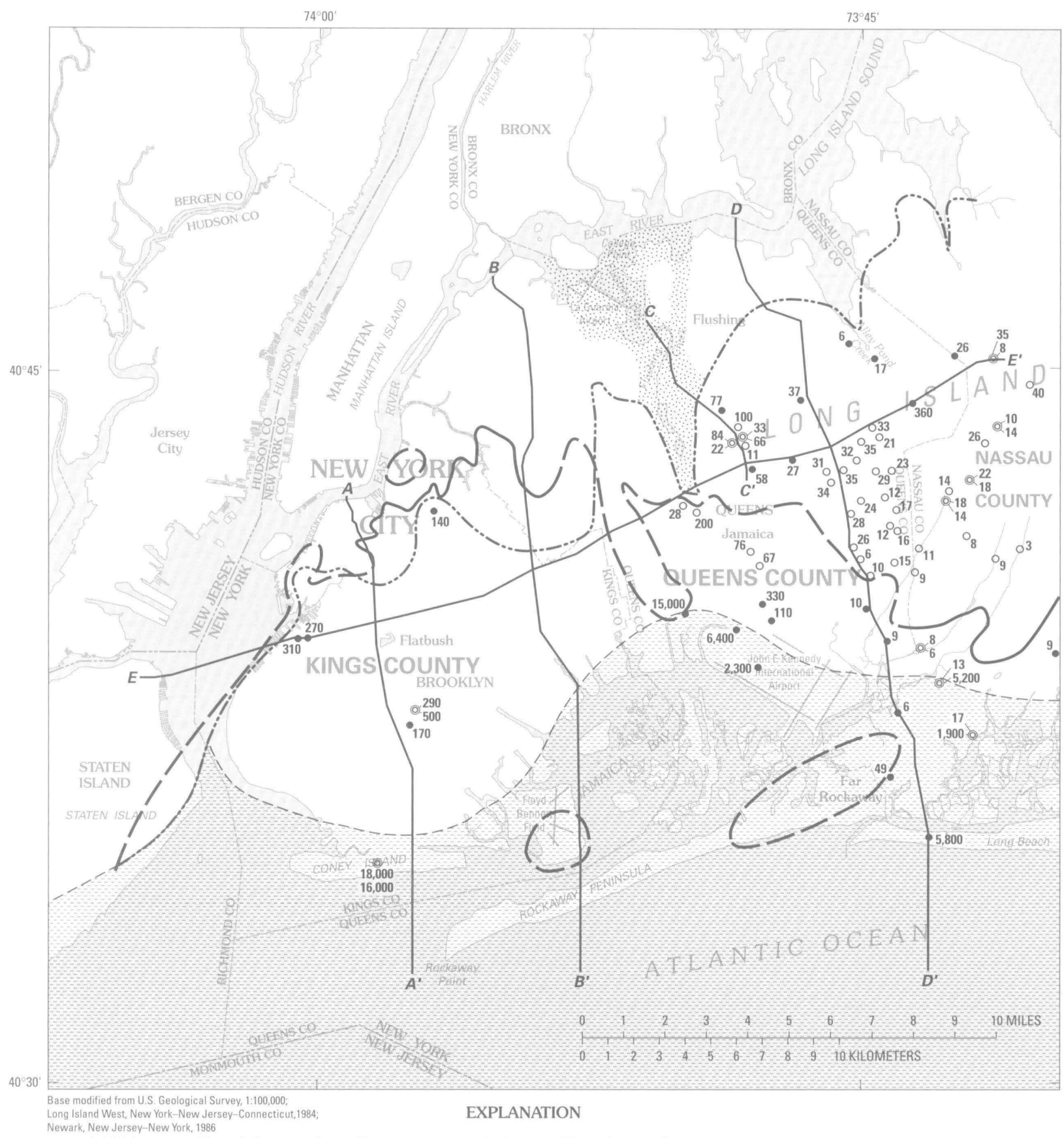

Newark, New Jersey-New York, 1986

Glacial deposits laterally contiguous with Jameco-Magothy aquifer

Area of salty ground water

Northern limit of Jameco-Magothy aquifer

_ - Northern limit of Gardiners clay-Dashed where approximately located

- - - - - - - Estimated position of toe of saltwater interface

$D \longrightarrow D^{\prime}$ Trace of hydrogeologic section section shown in figure 16

Well sampled by U.S. Geological Survey and analyzed by New York City Department of Environmental Protection-Number is chloride concentration, in milligrams per liter

$0^{76}$ Well sampled and analyzed by Jamaica Water-Supply Company-Number is chloride concentration, in milligrams per liter

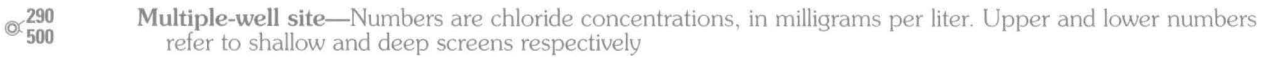

Figure 14A. Chloride concentrations in the Jameco-Magothy aquifer, 1983. 


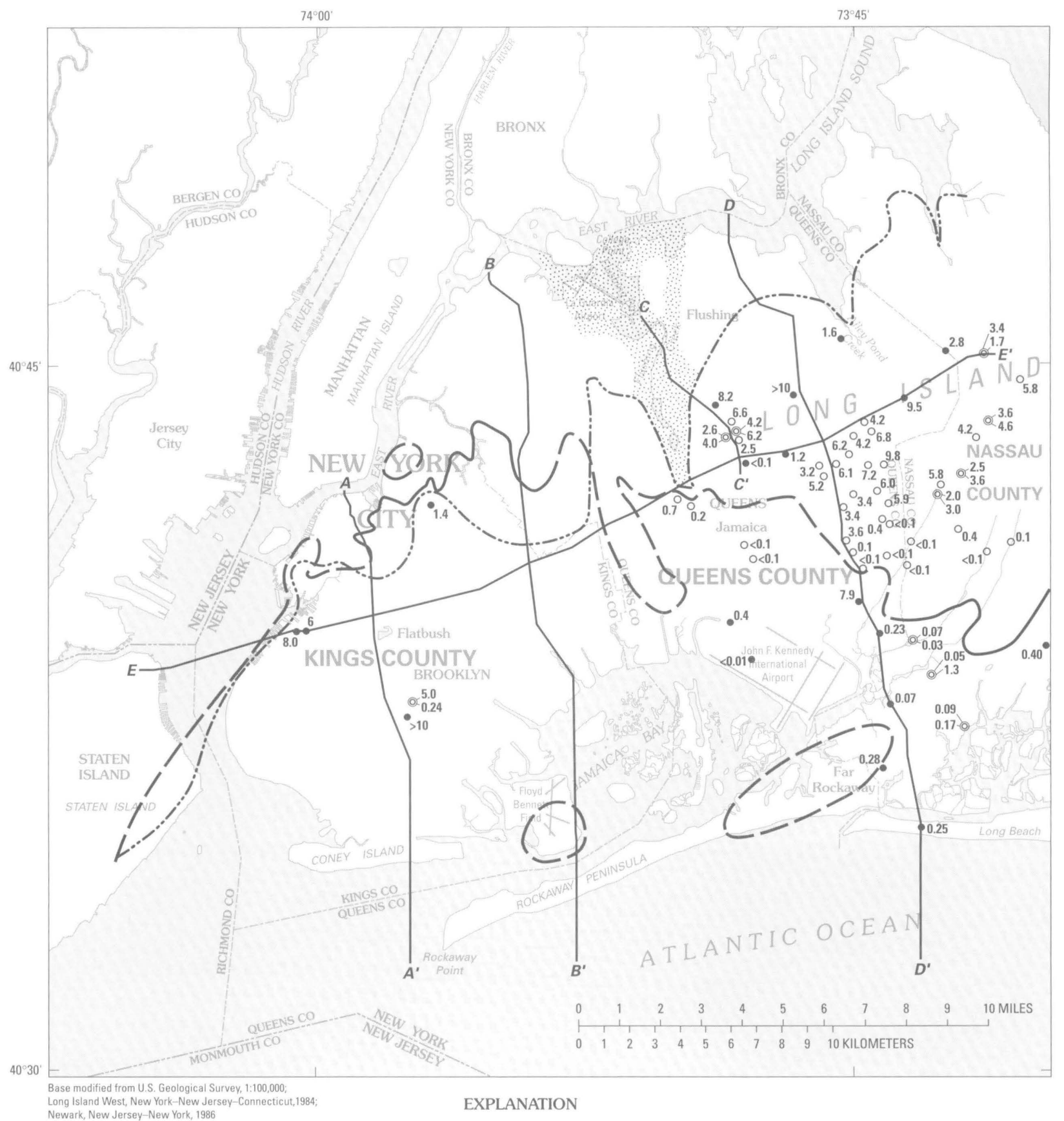

Newark, New Jersey-New York, 1986

Glacial deposits laterally contiguous with Jameco-Magothy aquifer

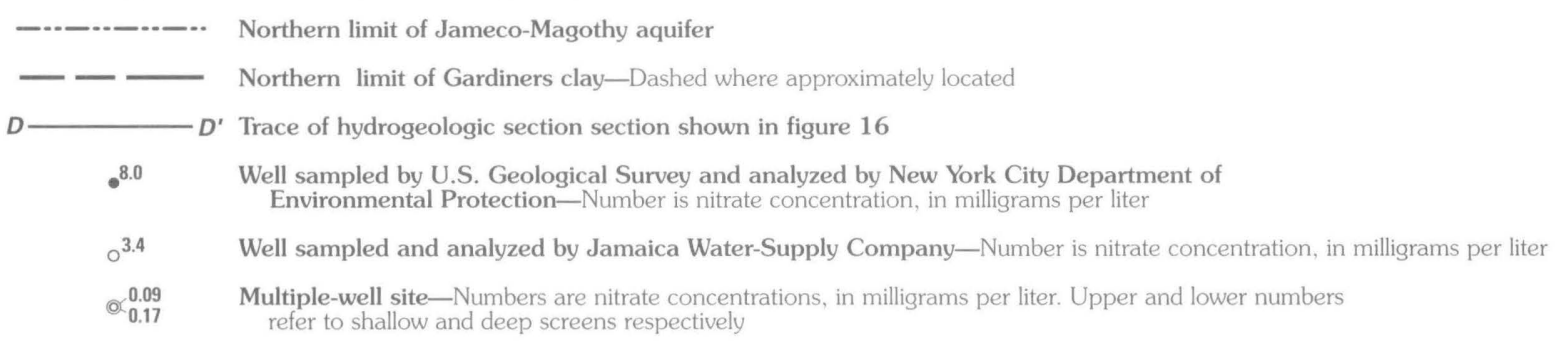

Figure 14B. Nitrate concentrations in the Jameco-Magothy aquifer, 1983. 


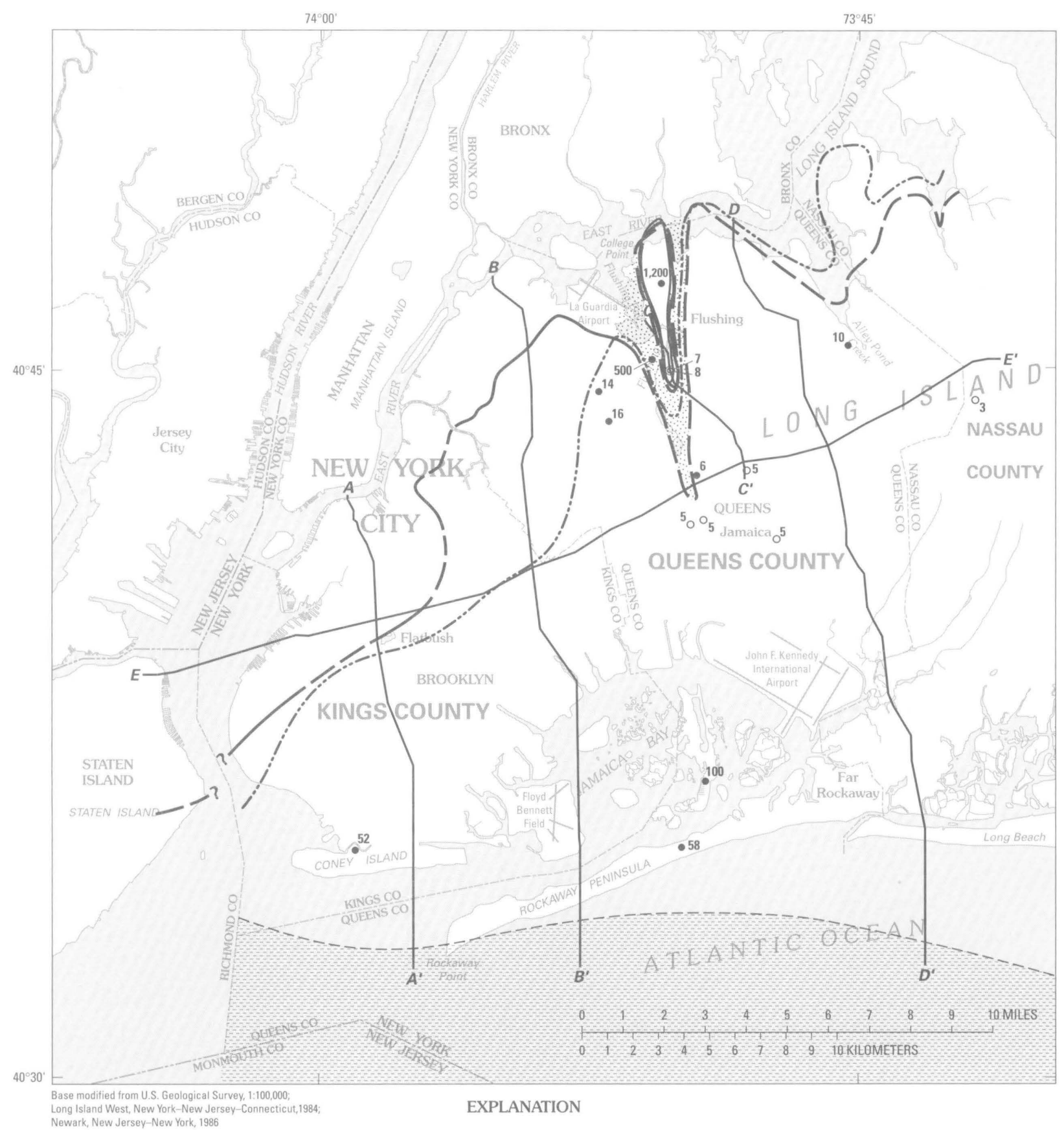

Newark, New Jersey-New York, 1986

Glacial deposits laterally contiguous with Lloyd aquifer

Area of salty ground water

Northern limit of Lloyd aquifer

? - Northern limit of clay member of the Raritan Formation-Dashed where approximately located, queried where unknown

$-------\quad$ Estimated position of toe of saltwater interface

$D \longrightarrow D^{\prime}$ Trace of hydrogeologic section section shown in figure 16

- 52 Well sampled by U.S. Geological Survey and analyzed by New York City Department of Environmental Protection-Number is chloride concentration, in milligrams per liter

$0^{5} \quad$ Well sampled and analyzed by Jamaica Water-Supply Company—Number is chloride concentration, in milligrams per liter

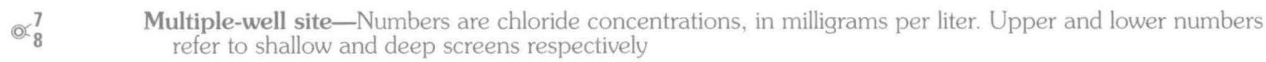

Figure 15A. Chloride concentrations in the Lloyd aquifer, 1983. 


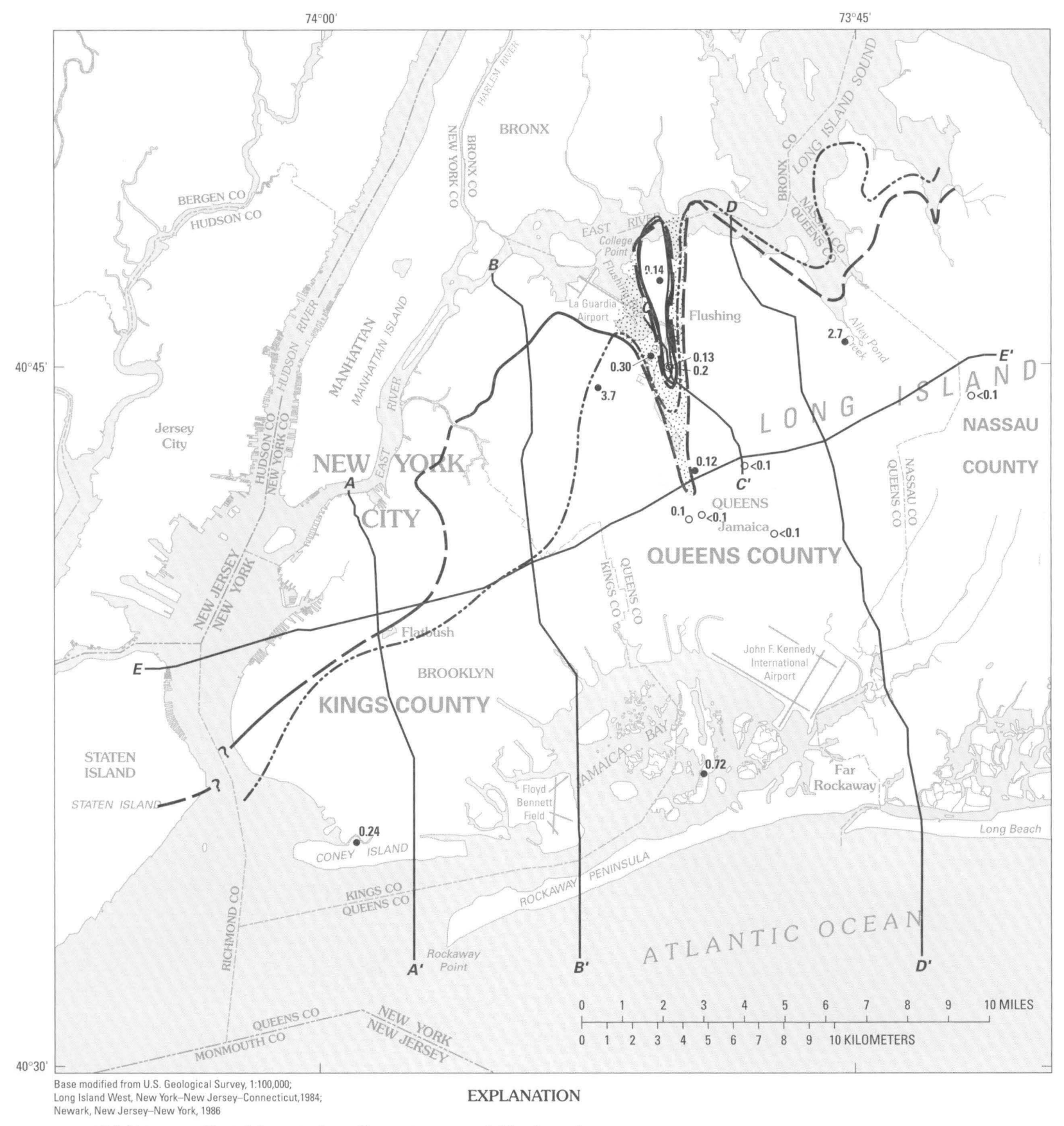

Glacial deposits laterally contiguous with Lloyd aquifer

-..-...-... Northern limit of Lloyd aquifer

? — - Northern limit of clay member of the Raritan Formation-Dashed where approximately located, queried where unknown

$D-D^{\prime}$ Trace of hydrogeologic section section shown in figure 16

@ 0.24 Well sampled by U.S. Geological Survey and analyzed by New York City Department of Environmental Protection-Number is nitrate concentration, in milligrams per liter

$0^{0.30} \quad$ Well sampled and analyzed by Jamaica Water-Supply Company-Number is nitrate concentration, in milligrams per liter

Multiple-well site-Numbers are nitrate concentrations, in milligrams per liter. Upper and lower numbers
o.13 refer to shallow and deep screens respectively

Figure 15B. Nitrate concentrations in the Lloyd aquifer, 1983. 


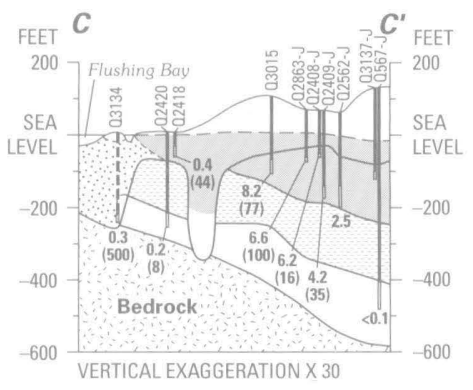

\section{EXPLANATION}

Area where nitrate concentration is expected to exceed 1.0 milligrams per liter (as $\mathrm{N}$ )

Area of salty ground water

Confining unit

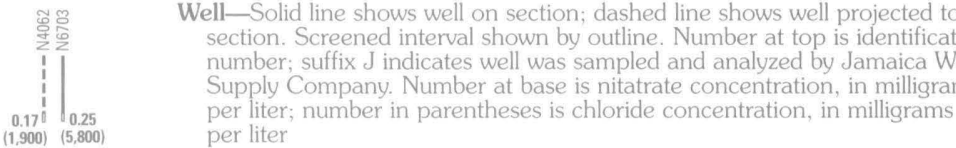

Well-Solid line shows well on section; dashed line shows well projected to
section. Screened interval shown by outline. Number at top is identification
number; suffix J indicates well was sampled and analyzed by Jamaica Water
Supply Company. Number at base is nitatrate concentration, in milligrams
0.170 per liter; number in parentheses is chloride concentration, in milligrams
$(1,900) \quad(5,800)$

Well-Solid line shows well on section; dashed line shows well projected to
section. Screened interval shown by outline. Number at top is identification
number; suffix J indicates well was sampled and analyzed by Jamaica Water
Supply Company. Number at base is nitatrate concentration, in milligrams
0.170 per liter; number in parentheses is chloride concentration, in milligrams

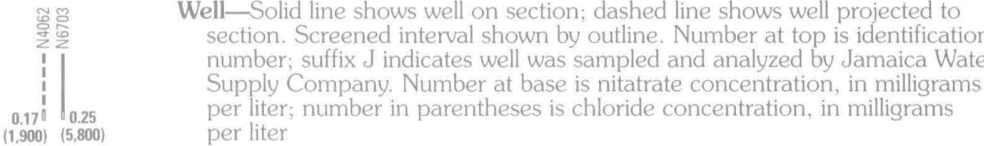

Well-Solid line shows well on section; dashed line shows well projected to
section. Screened interval shown by outline. Number at top is identification
number; suffix J indicates well was sampled and analyzed by Jamaica Wate

Water table
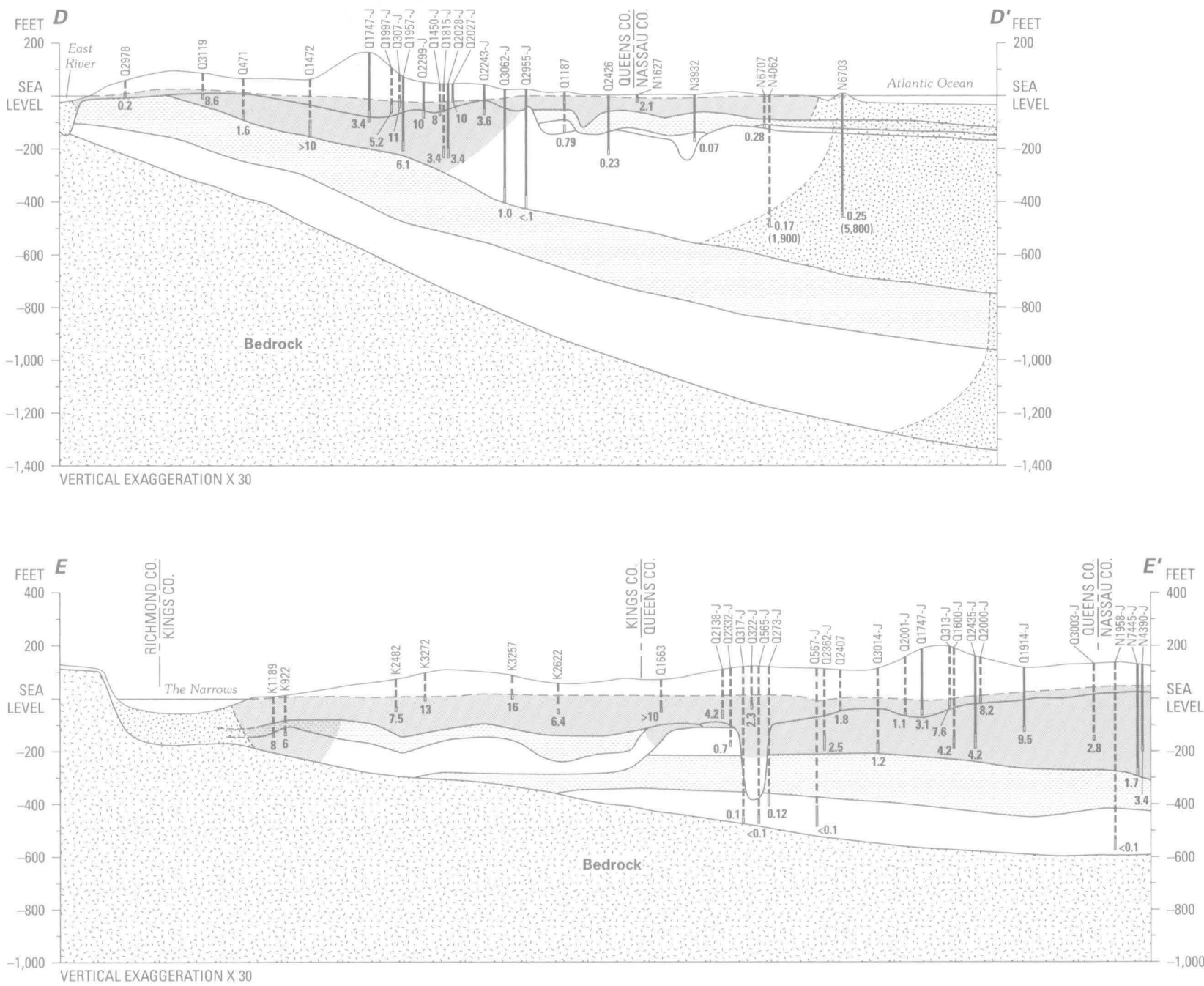

Figure 16. Nitrate and chloride concentrations along sections $C-C^{\prime}, D-D^{\prime}$, and $E-E^{\prime}$. (Trace of sections shown on plate 1.)

diners Clay is absent, 34 had nitrate concentrations greater than $2 \mathrm{mg} / \mathrm{L}$ (as $\mathrm{N}$ ).

The Gardiners Clay slows the downward movement of ground water, which suggests that water in the Jameco-Magothy aquifer beneath this confining unit is older than in areas where the unit is absent. Section D-
D’ (fig. 16) illustrates the difference between nitrate concentrations in the part of the Jameco-Magothy aquifer that is confined and protected by the Gardiners Clay and those in the part that is in good hydraulic connection with the upper glacial aquifer. Sections C-C' and E-E' (fig. 16) both show large areas where the confining 
unit is absent, and nitrate concentrations in the JamecoMagothy aquifer indicate contamination from land-surface sources

The Jameco-Magothy aquifer in Kings County is completely overlain by the Gardiners Clay As noted previously, however, the Gardıners Clay is much sandier in Kings than in Queens and would inhibit vertical flow much less Samples from four of six wells that tap the Jameco-Magothy in Kings County had nitrate concentrations ranging from $6 \mathrm{mg} / \mathrm{L}$ to more than $10 \mathrm{mg}$ / $\mathrm{L}$, which suggests that, as expected, flow rates through the Gardıners Clay are more rapıd in Kings County than in Queens

Of the 14 samples from the Lloyd aquifer, $12 \mathrm{had}$ nitrate concentrations ranging from less than 01 to $072 \mathrm{mg} / \mathrm{L}$ in 1983, this indicates little, if any, contamination from land surface The absence of land-surface contamination in the Lloyd aquifer is attributed to the aquifer's greater depth and to separation from overlying aquifers by the Raritan confining unit Franke and Cohen (1972) estımated that the age of water in the Lloyd aquifer was 1,000 to 10,000 years -1 or 2 orders of magnitude older than water in the shallower aquifers Therefore, this water entered the ground-water flow system (at the water table) long before the contamination from land surface appeared

Two factors suggest that water in the Lloyd aquifer in western Long Island could be younger than that farther east, however The first is the erosional channel that cuts through the Raritan confining unit in central Queens County and forms a pathway for more rapid vertical movement of ground water downward to the Lloyd aquifer (The area where Raritan and Lloyd deposits were eroded away and subsequently replaced by glacial material is shaded in figs $15 \mathrm{~A}$ and $15 \mathrm{~B}$, the erosional channel also is indicated in the sections in fig 16 ) The second factor is that the Lloyd aquifer in Kings and Queens Counties has been pumped since the turn of this century, and the increased downward gradients caused by this pumping have probably accelerated vertical ground-water movement The sections in figure 16 indicate that, even though water affected by man has not yet reached the Lloyd aquifer, the pathway for downward movement through the eroded channel in the Raritan confining unit could allow it to reach there within decades rather than the millennia it could take to move through the confining unit

\section{Saltwater Intrusion}

Ground water that has been affected by seawater is readily identıfied by elevated chloride along with other principal constıtuents of seawater (sodium, sulfate, and hardness) and low nitrate concentrations Total nitrogen concentration (as nitrate, nitrite, ammonia, and nitrogen gas) in seawater is $05 \mathrm{mg} / \mathrm{L}$ (as N) (Hem, 1970, p 11) Concentrations of chlonde and nitrate and the other principal constituents of seawater were used to define the general position of the zone of diffusion of the saltwater-freshwater interface

A history of intense pumping in Kings and western Queens Counties has caused the zone of diffusion in western Long Island to become more dispersed than anywhere else on Long Island In some areas, the res1due of past seawater intrusion extends inland and undoubtedly contributes to contamination that, when combined with elevated nitrate concentrations, appears to be solely of land-surface ongin Delineation of areas that have been affected by both seawater and land-surface contaminants was beyond the scope of this study, however

Chloride concentrations in the upper glacial aquifer ranged from 13 to $9,000 \mathrm{mg} / \mathrm{L}$ in 1983 (fig 13A) Chloride concentrations in inland areas of Kings and southwestern Queens County differ locally in an erratic fashion - concentrations of less than $20 \mathrm{mg} / \mathrm{L}$ can be found close to concentrations well over $200 \mathrm{mg} /$ L This could indicate a combination of past saltwater intrusion and land-surface-derived contamination In contrast, chloride concentrations in inland parts of eastern Queens and Nassau Counties range from 16 to 86 $\mathrm{mg} / \mathrm{L}$ and do not indicate saltwater intrusion Most samples with chlonde concentrations above $250 \mathrm{mg} / \mathrm{L}$ were from nearshore areas and indicate the landward extent of the zone of diffusion of the saltwater interface The saltwater interface, as a lateral boundary to the fresh ground-water system and as mapped in figures $14 \mathrm{~A}$ and $15 \mathrm{~A}$, 1s assumed to coincide with a chloride concentration of about $1,000 \mathrm{mg} / \mathrm{L}$

The three sections in figure 16 show that the saltwater interface in the upper glacial aquifer is close to shore The elevated chlonde concentration at well Q2418 (section C-C') indicates that it possibly is being drawn landward from Flushıng Bay (fig 13A, p 46)

The distribution of chlonde in samples from the Jameco-Magothy aquifer is shown in figure 14A (p 48) The interface configuration is based on the average values for the entire thickness of the aquifer and gives a general indication of the extent of salıne ground 
water in plan view The vertical configuration of the interface is shown in the hydrogeologic sections in figure 16 (p 52) The interface is expected to advance landward with depth, but data on chloride concentrations at the base of the Magothy aquifer are too sparse to indicate the landward extent of the toe of the interface Additional monitoring wells at the base of the Jameco-Magothy aquifer would be needed to ensure that saltwater intrusion has not progressed significantly farther inland there than in the shallower parts of the aquifer The interface is estimated to have migrated inland in southern Queens and southwestern Nassau Counties in response to the extensive pumping in southeastern Queens and Nassau Counties during recent years Elevated concentrations in wells K2510 and $\mathrm{K} 2511$, in the extreme south of Kings County (pl 7 and fig 14A), indicate that the saltwater interface in the Jameco-Magothy aquifer is inland in Kings County as well Chloride concentrations as high as $500 \mathrm{mg} / \mathrm{L}$ in samples from inland wells in Kings County could indicate a residue of past saltwater intrusion

Chloride concentrations at inland wells in Queens County are much lower than in Kings Only eight Queens wells had chloride concentrations exceeding $100 \mathrm{mg} / \mathrm{L}$, probably because pumping has been continually shifted eastward to avoid severe saltwater intrusion locally Except at three wells screened near the saltwater-freshwater interface, chloride concentrations in Nassau County wells were less than 50 $\mathrm{mg} / \mathrm{L}$

The Jameco-Magothy aquifer could have a potential for saltwater intrusion from the north shore near Flushıng Bay, where the aquifer is close to land surface and glacial deposits form a good hydraulic pathway for saltwater intrusion (fig 16, section C-C')

In the Lloyd aquifer, chlonde concentrations in samples from inland wells range from 3 to $16 \mathrm{mg} / \mathrm{L}$, within the predevelopment range Three samples taken along the south shore of Kings and Queens Counties had chloride concentrations between 50 and $100 \mathrm{mg} / \mathrm{L}$, which probably indicates the farthest landward extent of the saltwater-freshwater interface These data are insufficient to indicate how rapidly the chloride concentrations increase seaward, however The configuration of the interface, as shown in figure 15A (p 50) is estımated

As shown in the sections in figure 16, the interface in the Lloyd aquifer on the north shore is close to the northern edge of the Raritan confining unit, which in this area is close to the shore Several wells on the north shore have elevated chlonde concentrations, ind1catıng possible saltwater intrusion Well Q1373 in College Point (pl 7) had a chlonde concentration of 1,200 $\mathrm{mg} / \mathrm{L}$ in 1983 This well, along with well Q1374 (not sampled) at the same location and depth, were industrial pumping wells drilled in 1946 This pumping induced the saltwater to move into the College Point area Soren (1971) reports that Q1374 had a chloride concentration of $1,718 \mathrm{mg} / \mathrm{L}$ in 1955

The extensive regional cone of depression in the Lloyd aquifer could be sufficient to induce saltwater intrusion from the north as well as the south shore Salıne ground water could affect the Lloyd aquifer (fig 16) either by lateral movement of the interface from its current position in the Lloyd or by vertical migration through the channel in the Raritan confining unit Well Q3134 (figs 15A and section C-C' in fig 16), in the erosional channel in the Raritan confining unit near Flushing Bay, had a chloride concentration of $500 \mathrm{mg} /$ L in 1983 Saline ground water probably was drawn into the Flushing area during the 1964-65 World's Fair, when large-scale ground-water withdrawals occurred (Soren, 1971, p A32) Additional discussion of the movement of the saltwater-freshwater interface is given in the earlier section, "Water-Table and Potentıometric-Surface Altitudes"

\section{Inorganıc Constituents}

As described in the previous section, two general trends are observed in the concentrations of humaninduced inorganic constituents in ground water in western Long Island Concentrations tend to decrease eastward in each aquifer and also with depth at any location These trends reflect the facts that (1) development began in western Kings County and progressed eastward, and (2) land use today ranges from intense urbanızation in Kings to mixed residential-industrial use in western Nassau These trends in individual aquifers are discussed in the following paragraphs

\section{Upper Glacial Aquifer}

The analyses of samples from 96 wells in the upper glacial aquifer during 1983 (table 10, at end of report) indicate that human activities have altered the ground water's natural chemical composition The dissolved-solids concentration, a measure of all chemical constituents dissolved in ground water, is elevated throughout the upper glacial aquifer in Kings and Queens, all samples had concentrations greater than 
$100 \mathrm{mg} / \mathrm{L}$ Under natural conditions, the dissolved-sol1ds concentration is extremely low, generally below 35 $\mathrm{mg} / \mathrm{L}$ (table 3 ) These data indicate that the publichealth standard of $500 \mathrm{mg} / \mathrm{L}$ is exceeded at 33 wells-18 in Kings and 15 in Queens

Hardness values have risen since development (table 3) Predevelopment concentrations in Kings and Queens Counties were less than $25 \mathrm{mg} / \mathrm{L}$ (as $\mathrm{CaCO}_{3}$ ), but 1983 values ranged from 42 to $3,100 \mathrm{mg} / \mathrm{L}$ (except one sample, which had $20 \mathrm{mg} / \mathrm{L}$ ) Except for five wells that were considered to be significantly affected by seawater (chloride and hardness concentrations $650 \mathrm{mg} / \mathrm{L}$ or above), hardness values ranged from 20 to $740 \mathrm{mg}$ / L in Kings County, from 42 to $440 \mathrm{mg} / \mathrm{L}$ in Queens, and from 54 to $250 \mathrm{mg} / \mathrm{L}$ in Nassau Higher concentratıons in Kings are caused at least in part by a residue of saltwater intrusion from the 1940's

Fluoride concentrations are extremely low in ground water throughout Kıngs and Queens Counties Natural concentrations are $05 \mathrm{mg} / \mathrm{L}$ or less and are probably denved from dissolution of amphibole, hornblende, and mica (Hem, 1970) Most ground-water contaminants (manmade waste and saltwater) do not contain significant concentrations of fluoride Seven wells in Kings and Queens had fluoride concentrations ranging from 08 to $10 \mathrm{mg} / \mathrm{L}$ Fluonde is added to the drınkıng-water supply of New York City at an average concentration of $093 \mathrm{mg} / \mathrm{L}$ (New York City Department of Environmental Protection, written commun , 1984) Therefore, these concentrations could indicate leakage from water-supply lines

Sulfate concentrations are considerably higher than in predevelopment times, when they were less than $12 \mathrm{mg} / \mathrm{L}$ (table 3) Only 3 of 67 wells in Kıngs and Queens in 1983 had sulfate concentrations less than 12 $\mathrm{mg} / \mathrm{L}$, the maxımum observed value in samples representative of predevelopment conditions Samples from the remaining wells, excluding two affected by seawater, ranged from 15 to $200 \mathrm{mg} / \mathrm{L}$ and averaged about 75 $\mathrm{mg} / \mathrm{L}$ No distınct east-west trend is evident from these data

\section{Jameco-Magothy Aquifer}

Analyses of samples from 80 wells screened in the Magothy-Jameco aquifer are available Eight of these are in Kings County (all are screened in the Jameco), 47 are in Queens, and 25 are in Nassau

The dissolved-solids concentrations of almost all samples from the Jameco-Magothy aquifer exceed predevelopment levels The eight samples from Kings
County had the highest concentrations - all were above the $500-\mathrm{mg} / \mathrm{L}$ public-health standard The dissolvedsolids concentrations in 39 of 44 samples from Queens County were below the public health standard, and 28 were below $250 \mathrm{mg} / \mathrm{L}$ Wells in Nassau County showed still lower dissolved-solids concentrations Except for two samples that were affected by seawater, concentrations in 17 samples ranged from 32 to 224 $\mathrm{mg} / \mathrm{L}$

The hardness of samples ranged from a low of 8 $\mathrm{mg} / \mathrm{L}\left(\right.$ as $\left.\mathrm{CaCO}_{3}\right)$ in Nassau County to a high of 14,000 $\mathrm{mg} / \mathrm{L}$ in a well affected by seawater in southern Queens Except for nine wells affected by seawater (chloride and hardness concentrations of $1,100 \mathrm{mg} / \mathrm{L}$ or above), values ranged from moderately hard to hard, averaging $330 \mathrm{mg} / \mathrm{L}$ in Kings County, $140 \mathrm{mg} / \mathrm{L}$ in Queens, and $38 \mathrm{mg} / \mathrm{L}$ in western Nassau

Sulfate concentrations in the Jameco-Magothy aquifer were slightly above predevelopment concentrations but were lower than those in the upper glacial aquifer Except for the same nine wells that were affected by seawater, sulfate concentrations were less than $100 \mathrm{mg} / \mathrm{L}$ in Kings County, less than $110 \mathrm{mg} / \mathrm{L}$ in Queens, and less than $63 \mathrm{mg} / \mathrm{L}$ in Nassau

\section{Lloyd Aquifer}

Analyses are avallable from only 15 wells screened in the Lloyd aquifer (which has only a few wells because drilling to that depth is costly, and water is generally available from the other aquifers ) Of these wells, 13 are in Queens County, 1 is in Kings, and 1 is in western Nassau One well (Q1373, pl 8), on the north shore of Queens County, where the Lloyd aquifer 1s close to land surface, is affected by seawater, at the remaining 14 wells, the total dissolved-solids concentration was $265 \mathrm{mg} / \mathrm{L}$ or less and, at 7 wells, was 100 $\mathrm{mg} / \mathrm{L}$ or less Hardness at those 14 wells was less than $65 \mathrm{mg} / \mathrm{L}$, and sulfate concentrations were less than 35 $\mathrm{mg} / \mathrm{L}$, in 10 wells they were less than $20 \mathrm{mg} / \mathrm{L}$

\section{Organıc Constıtuents}

The widespread use of a variety of organic compounds in highly industrialized and urbanized areas of western Long Island has created concern over the potential for ground-water contamination Even though the toxicity of many organic compounds is unknown, their distribution is a critical factor in dec1sions as to where ground water is safe for drinking 
No extensive ground-water-sampling effort had been undertaken in Kings or Queens Counties before this project to document the presence of organic compounds, only ground water pumped in southeastern Queens by the Jamaica Water Supply Company is routinely monitored for organic compounds This monitoring began in 1979 and is under the auspices of the New York City Department of Health Results indicate contamination by organic compounds During the fall and winter of 1983, when 54 wells of the Jamaica Water Supply Company were sampled for total volatıle organic compounds, 42 showed detectable levels (detection lımit 01 parts per billion, ppb) (New York City Department of Health, 1984 ) Of these 42 wells, two exceeded the recommended guidelines set by the New York City Department of Health (1984) and were ordered closed by that department Since the Department of Health began monitoring in 1979, it has ordered 14 wells closed for exceeding the guidelines, 12 of these wells are screened in the upper glacial aquifer, and the remaining two in the Magothy aquifer The closed wells could be monitored and reopened if the concentrations of organic compounds drop below the recommended guidelines

Detectable levels of organic contamination have been found mostly in the upper glacial and Magothy aquifers, where most of the pumping occurs The New York City Department of Health (1984) reports that, in 1983, detectable levels of contamination were found at 22 of 23 wells screened in the upper glacial aquifer, at 19 of 25 wells screened in the Magothy aquifer, and at 1 of 4 wells screened in the Lloyd aquifer Two wells screened in the Jameco aquifer showed no contamination

The New York City Department of Health (1984) also reports that samples from 28 contaminated wells contained more than one organic compound, a total of 16 different volatıle organic compounds were detected in 1983

Data from southeastern Queens County indicate that organic compounds have migrated through the upper glacial aquifer and into the Jameco-Magothy aquifer Many of the organic compounds enter the ground-water system from sporadic, dispersed point sources, which makes correlation extremely difficult In fact, some wells found not to have detectable levels of organıc compounds at one samplıng may contain detectable levels at a subsequent sampling as sporadic and irregular plumes pass the well screen These data are few, however, and whether the conclusions drawn from them can be applied to the rest of western Long Island is uncertain Yet, ground water that contains other indicators of land-surface contamination, as described in the previous section, would have the highest probability of containing organic compounds as well

\section{GROUND-WATER-RESOURCE CONCERNS}

The hydrologic conditions observed in 1983 indicate that pumping has caused an extensive cone of depression in all three major aquifers Whether current pumping exceeds the safe yield of the aquifer system is difficult to determine untıl unacceptable levels of specific undesirable hydrologic effects of development have been identified and measured Undesired results of ground-water development on western Long Island include severe water-level declines, intrusion of salıne ground water, downward migration of land-surface contamination into confined aquifers, and flooding of underground structures The first three are closely related, in that extreme drawdown that results from pumping of deep aquifers will increase the rate of landward movement of the saltwater-freshwater interface and the rate of downward movement of contaminants (introduced at the water table) into confined aquifers The major result of these undesired effects is that the potable ground-water supply would be contınually dımınıshed

The data in this report indicate that the saltwaterfreshwater interface is moving landward and that contaminants in shallow aquifers are moving into the confined aquifers Any increase in pumping will accelerate these effects to some extent, however, a realistic resource-management strategy could include location of wells in inland areas beyond the threat of saltwater intrusion, and beneath the extent of migration of landsurface contaminants which would prolong the period until treatment is needed to maintain an adequate supply of potable water

With the liklihood of additional decreases in ground-water pumping, flooding of underground structures by rising water levels is another serious concern Such flooding is already occurring in areas where pumpıng has been curtailed and could extend farther if present pumping rates are reduced Reducing groundwater pumpage while increasing the use of upstate surface water would require monitoring of ground-water levels, especially near shores and buried stream chan- 
nels, where depths to water are smallest Redistribution of pumping for public supply can provide a means to mitigate both severe drawdown in the east and excessive water levels farther west, but significant financial, institutional, and water-quality considerations would need to be resolved first

Ground-water quality is worst in the westernmost and shallowest parts of the aquifer system but 1mproves eastward and with depth Potable ground water is still largely ava1lable in eastern Queens, even from the upper glacial aquifer, but probably not in areas farther west The Lloyd aquifer, which is still uncontaminated, cannot greatly supplement the supply because it is sensitive to pumping and is expected to yield only small volumes of water without incurring excessive drawdown Therefore, redistribution of ground-water pumping, even at current rates, would probably require some treatment to ensure potable quality

In 1983 , only about $60 \mathrm{Mgal} / \mathrm{d}$, or 8 percent, of the $750 \mathrm{Mgal} / \mathrm{d}$ used for public supply in Kings and Queens Counties was denved locally from ground water, the remainder was supplied from an upstate surface-water-reservoir system A conjunctive-resourcedevelopment strategy that takes advantage of the inherent differences in the nature of ground-water and surface-water systems could enable a reduction in the harmful effects of the present development strategy At present, water is developed contınuously from both sources and used in separate areas The use of ground water as a periodic supplement to the surface-water supply could result in a combined system with greater productivity than the separate ground- and surfacewater-supply systems as they are operated at present

\section{SUMMARY}

The aquifers underlyıng Kings and Queens Counties supplied an average of about $120 \mathrm{Mgal} / \mathrm{d}$ during 1904-47 Intensive pumping in Kings County during the 1930's lowered ground-water levels and caused intrusion of saline ground water into the upper glacial and Jameco-Magothy aquifers unt1l 1947, when all pumping for public supply in the county was stopped Subsequently, pumping in Queens County has been increased A severe cone of depression that developed in southwestern Queens County during the 1960's also caused intrusion of salıne ground water, as a result, pumping for public supply in the Woodhaven franchise area of the New York Water Supply Company was halted in 1974 Pumping for public supply has persisted in eastern Queens County, where the Jamarca Water Supply Company has pumped an average of about 60 Mgal/d since 1974

Since the cessation of pumping in Kings and southwestern Queens, ground-water levels have been recovernng steadily In 1983, ground-water levels in Kıngs were close to predevelopment levels, and contamination by saltwater had partly dispersed and become diluted An extensive cone of depression remains in all three major aquifers in eastern Queens County, however The saltwater-freshwater interface in the Jameco-Magothy aquifer, which is already inland, is moving toward the center of pumping Avallable data indicate that saline ground water in the Lloyd aquifer is not far offshore and is also moving landward

At present, elevated nitrate and chloride concentrations throughout the upper glacial aquifer indicate widespread contamination from land surface Some contamination in the Jameco-Magothy aquifer is attributed to downward migration in areas of substantial hydraulic connection between aquifers (where the Gardiners Clay is absent) A channel eroded through the Raritan confining unit provides a pathway for migration of contaminants to the Lloyd aquifer The cone of depression in the Lloyd has increased the downward gradients through this channel, which could cause contaminants to enter the Lloyd sooner than anticipated

Although chloride and nitrate have been used as the principal indicators of ground-water contamination, other constituents introduced from point sources also may affect ground-water quality locally The extent to which nitrate and chlonde from the land surface have moved through the ground-water system indicates that treatment eventually could be needed to ensure the quality of water pumped from the upper glacral or Jameco-Magothy aquifers Ground water in the Lloyd aquifer is still largely uncontaminated, but present pumpage and ground-water levels indicate that this aquifer is much more sensitive to withdrawals than the overlying aquifers and could be more susceptible to contamination from land-surface sources in western Long Island than in other areas

\section{REFERENCES CITED}

American Public Health Association, 1976, Standard methods for the examination of water and waste water, 14th ed Washington, D C, American Public Health Association, 543 p 
Burr, W H , Herıng, Rudolph, and Freeman, J R , 1904, Report of the commission on additional water supply for the City of New York New York, Martın B Brown, $980 \mathrm{p}$

Buxton, H T, Soren, Julian, Posner, Alex, and Shernoff, PK, 1981, Reconnaissance of the ground-water resources of Kıngs and Queens Count1es, New York U S Geological Survey Open-File Report

81-1186, $59 \mathrm{p}$

Cohen, Philip, Franke, O L , and Foxworthy, B L , 1968, An atlas of Long Island's water resources New York State Water Resources Commission

Bulletın 62, $117 \mathrm{p}$

deLaguna, Wallace, 1948, Geologic correlation of logs of wells in Kings County, New York New York State Water Power and Control Commission Bulletın GW-17, $35 \mathrm{p}$

1964, Chemical quality of water, Brookhaven Natıonal Laboratory and vicinıty, Suffolk County, New York U S Geological Survey Bulletın 1156-D, 73 p

Franke, O L , and Cohen, Philıp, 1972, Regional rates of ground-water movement on Long Island, New York, in Geological Survey Research 1972, in U S Geological Survey Professional Paper 800-C, p C271-277

Franke, O L , and McClymonds, N E , 1972, Summary of the hydrologic situation on Long Island, New York, as a guide to water-management alternatıves U S Geolog1cal Survey Professional Paper 627-F, $59 \mathrm{p}$

Fuller, M L , 1914, The geology of Long Island, New York U S Geological Survey Professional Paper 82, 231 p

Hem, J D , 1970, Study and interpretation of the chemical characternstics of natural water U S Geological Survey Water-Supply Paper 1473, 363 p

Jackson, D D , 1905, The normal distribution of chlorine in the natural waters of New York and New England U S Geological Survey Water-Supply and Irngation Paper $144,31 \mathrm{p}$

Jacob, C E , 1945, The water table in western and central parts of Long Island, New York New York State Water Power and Control Commission Bulletın GW-12, $24 \mathrm{p}$

Johnson, A H , and Waterman, W G , 1952, Withdrawal of ground water on Long Island, New York New York State Water Power and Control Commission Bulletın GW-28, 13 p

Kımmel, G E , 1972, Nitrogen content of ground water in Kings County, Long Island, New York, in Geological Survey Research 1972, U S Geological Survey Professional Paper 800-D, p D199-D203

Koszalka, E J , 1975, The water table on Long Island, New York, in March 1974 Suffolk County Water Authority, Long Island Water Resources Bulletın 5, 7 p

Leggette, R M , and Brashears, M L , Jr, 1938, Ground water for air-conditioning on Long Island, New York, in Transactions of the American Geophysical Union 19th Annual Meetıng, pt 1, p 412-418
Lusczynskı, N J , 1952, The recovery of ground-water levels in Brooklyn, New York, from 1947 to 1950 U S Geological Survey Circular 167, $29 \mathrm{p}$

Lusczynsk1, N J , and Johnson, A W, 1951, The water table in Long Island, New York, in January 1951 New York State Water Power and Control Commission Bulletın GW-27, 28 p

Lusczynskı, N J , and Swarzenskı, W V, 1966, Salt-water encroachment in southern Nassau and southeastern Queens Counties, Long Island, New York U S Geological Survey Water-Supply Paper 1613-F, $76 \mathrm{p}$

McClymonds, N E , and Franke, O L , 1972, Water-transmittıng properties of aquifers on Long Island, New York U S Geological Survey Professional Paper 627-E, 24 p

Miller, J F, and Frederick, R H, 1969, The precipitation regime of Long Island, N Y U S Geological Survey Professional Paper 627-A, $21 \mathrm{p}$

New York City Department of Environmental Protection, 1981, Annual report of Bureau of Water Supply, 1981 New York City Department of Environmental Protection, Bureau of Water Supply, $126 \mathrm{p}$

1979, Areawide waste treatment management planning program New York City Department of Environmental Protection, Section 208, final report, 124 p

New York City Department of Health, 1984, Jamaica Water Supply Company well sampling and well field survey, 1983 New York City Department of Health summary report, $18 \mathrm{p}$

New York City Department of Water Supply, Gas and Electricity, 1962, Annual report of the Bureau of Water Supply for 1961 New York City Department of Water Supply, Gas and Electricity, Bureau of Water Supply, $135 \mathrm{p}$

1948, Annual report of the Chief Engineer for 1947

New York City Department of Water Supply, Gas and Electricity, Bureau of Water Supply, $100 \mathrm{p}$

New York City Environmental Protection Admınıstratıon, 1971, Annual report of Bureau of Water Supply, 1970 New York City Environmental Protectıon Admınıstration, Department of Water Resources, Bureau of Water Supply, $109 \mathrm{p}$

New York State Department of Health, 1977, New York State Water Supervision Program New York State Department of Health, Division of Sanitary Engineerıng, Bureau of Water Supply, State Sanitary Code, Subpart 5-1 Public Water Supplies, p $1-46$

Pearson, F J , Jr , and Fisher, D W, 1971, Chemical composition of atmospheric precipitation in Northeastern United States U S Geological Survey Water-Supply Paper 1535-P, $23 \mathrm{p}$

Perlmutter, N M , and Soren, Julıan, 1962, Effects of major water-table changes in Kings and Queens Counties, New York City, in Geological Survey Research 1962 
U S Geological Survey Professional Paper 450-E, p E136-E139

Smolensky, D A , Buxton, H T, and Shernoff, PK , 1989, Hydrogeologic framework of Long Island, New York U S Geological Survey Hydrologic Atlas HA-709, 3 sheets, scale 1250,000

Soren, Julıan, 1971, ground-water and geohydrologic cond1tions in Queens County, Long Island, New York U S Geological Survey Water-Supply Paper 2001-A, 39 p 1976, Basement flooding and foundation damage from water-table rise in the east New York sectionof Brooklyn, Long Island, New York U S Geological Survey Water Resources Investigations 76-95, $14 \mathrm{p}$

1978, Subsurface geology and paleogeography of Queens County, Long Island, New York U S Geological Survey Water Resources Investigations Open-File Report 77-34, $17 \mathrm{p}$

Spear, W E , 1912, Long Island sources-an additional supply of water for the City of New York New York City Board of Water Supply, $708 \mathrm{p}$

Suter, Russell, 1937, Engineering report on the water supplies of Long Island New York State Water Power and Control Commıssion Bulletın GW-2, 64 p
Suter, Russell, de Laguna, Wallace, and Perlmutter, N M , 1949, Mapping of geologic formations and aquifers of Long Island, New York New York State Water Power and Control Commission Bulletın GW-18, $212 \mathrm{p}$

Thompson, D G , and Leggette, R M , 1936, Withdrawal of ground water on Long Island, New York New York State Water Power and Control Commıssıon Bulletın GW-1, $28 \mathrm{p}$

U S Geological Survey, 1965, Water resources data for New York, Part 2, water-quality records U S Geological Survey Open-File Report, 112 p (issued annually)

Veatch, A C, Slichter, C S Bowman, Isarah, Crosby, W O, and Horton, R E , 1906, Underground water resources of Long Island, New York U S Geological Survey Professional Paper 44, $394 \mathrm{p}$

Vecchıll, John, Bennett, G D , Pearson, F J , Jr , and Cerrillo, L A , 1974, Geohydrology of the artıficialrecharge site at Bay Park, Long Island, New York U S Geological Survey Professional Paper 751-C, 29 p

Weast, R C (ed ), 1981, CRC handbook of chemistry and physics, 62d Edition Boca Raton, Fla , CRC Press Inc, chapters A-F 

TABLES OF WELL AND CHEMICAL DATA 


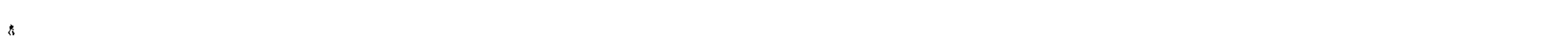


Table 7 Wells and test borıngs plotted on plate 1 that occupy a multıple well site

\begin{tabular}{|c|c|c|c|c|c|}
\hline $\begin{array}{c}\text { Well } \\
\text { number }\end{array}$ & $\begin{array}{l}\text { Other wells } \\
\text { at same site } \\
\text { or nearby }\end{array}$ & $\begin{array}{c}\text { Well } \\
\text { number }\end{array}$ & $\begin{array}{l}\text { Other wells } \\
\text { at same site } \\
\text { or nearby }\end{array}$ & $\begin{array}{c}\text { Well } \\
\text { number }\end{array}$ & $\begin{array}{l}\text { Other wells } \\
\text { at same site } \\
\text { or nearby }\end{array}$ \\
\hline & Kıngs County & \multicolumn{2}{|c|}{ Nassau County (contınued) } & \multicolumn{2}{|c|}{ Queens County (contınued) } \\
\hline K320 & $\mathrm{K} 259, \mathrm{~K} 277$ & N5110 & N1618 & Q1812 & Q1787 \\
\hline K531 & K526 & N5576 & N1686, N1687 & Q1815 & Q1450 \\
\hline K533 & K520 & N6581 & N3864 & Q1839 & Q306, Q561, Q572 \\
\hline K640 4 & K640 1, K640 2, K640 3 & N6701 & N4405 & Q1876 & Q336, Q1861 \\
\hline K642 2 & K642 1 & N8456 & N8375 & Q1914 & Q581, Q582 \\
\hline K656 & K290 & N8840 & N8821 & Q1932 & Q111, Q1929, Q1930, Q1931 \\
\hline K725 & K694 & N9110 & $\mathrm{N} 23, \mathrm{~N} 8342$ & Q1957 & Q1311, Q1923 \\
\hline K731 & K676 & N9151 & N11 & Q1965 & Q1035, Q1239, Q1275 \\
\hline K898 & K673 & N9308 & $\mathrm{N} 2$ & Q2001 & Q1985 \\
\hline K920 & K916 & \multirow{2}{*}{\multicolumn{2}{|c|}{ Queens County }} & Q2028 & Q2003 \\
\hline K1010 & K639 & & & Q2137 & Q318, Q567 \\
\hline K1030 & K930, K956 & Q268 & Q64 & Q2148 & Q364, Q1978, Q1979 \\
\hline K1031 & K887 & Q267 & Q275 & Q2188 & Q1982, Q2000 \\
\hline K1073 & K660 & Q283 & Q282 & Q2189 & Q2140 \\
\hline K1091 & K720 & Q455 & Q33 & Q2243 & Q2205 \\
\hline K1112 & K49 & Q484 & Q460, Q461, Q462, Q464, & Q2276 & Q2259, Q2275 \\
\hline K1130 & K893, K955 & & Q466, Q468, Q480 & Q2300 & Q2255, Q2299 \\
\hline K1148 & K167 & Q453 & Q425 & Q2332 & Q2122, Q2138, Q2325 \\
\hline K1191 & K1190 & Q495 & Q490, Q491, Q492, Q493, Q494 & Q2333 & Q1258 \\
\hline K1283 & K724 & Q564 & Q563 & Q2356 & Q1423 \\
\hline K1286 & K538 & Q566 & Q317 & Q2374 & Q2364, Q2373 \\
\hline K1332 & K638 & Q571 & Q324, Q556 & Q2384 & Q350, Q2289 \\
\hline K1340 & K1313, K1319 & Q584 & Q572, Q273 & Q2394 & Q2273, Q2390, Q2393 \\
\hline K1346 & K1343 & Q602 & Q386 & Q2400B & Q447, Q2386, Q2400A \\
\hline K1360 & K1355 & Q634 & Q340 & Q2402 & Q2377 \\
\hline K1490 & $\mathrm{K} 37$ & Q678 & Q224 & Q2409 & Q2361, Q2408 \\
\hline \multirow[t]{2}{*}{ K1548 } & K82, K1015, K1018, K1288, & Q1027 & Q1026 & Q2413 & Q586 \\
\hline & $\mathrm{K} 1488$ & Q1028 & Q440, Q444 & Q2420 & Q441, Q2416, Q2419 \\
\hline K1558 & $\mathrm{K} 178$ & Q1037 & Q985, Q1036 & Q2432 & Q2405 \\
\hline K1641 & K1287 & Q1053 & Q1048, Q1049 & Q2435 & Q2404 \\
\hline K1977 & K675 & Q1057 & Q278, Q1041, Q1042, Q1043, & Q2443 & Q310, Q1924, Q1958, Q2430 \\
\hline K2069 & K33 & & Q1045, Q1056 & Q2592 & Q2144, Q2309 \\
\hline K2070 & K944, K1012 & Q1071 & Q542 & Q2955 & Q2765 \\
\hline K2136 & $\mathrm{K} 1153, \mathrm{~K} 1273, \mathrm{~K} 1336$ & Q1098 & Q453 & Q3000 & Q1472 \\
\hline K2262 & K1303 & Q1175 & Q339, Q680 & Q3003 & Q1850, Q1909, Q2987 \\
\hline $\mathrm{K} 2513$ & K2512 & Q1197 & Q333 & Q3012 & Q1372, Q1384 \\
\hline $\mathrm{K} 2533$ & K637 & Q1241 & Q1086, Q1087 & Q3014 & Q2991 \\
\hline K3132 & $\mathrm{K} 3129, \mathrm{~K} 3130, \mathrm{~K} 3131$ & Q1274 & Q437 & Q3034 & Q3026 \\
\hline \multirow[t]{3}{*}{ K3133 } & K64 2, K64 5, K64 6, K1160, & Q1305 & Q334 & Q3036 & Q3030 \\
\hline & $\mathrm{K} 1274, \mathrm{~K} 1275, \mathrm{~K} 1305, \mathrm{~K} 1344$, & Q1379 & Q1376 & Q3062 & Q3029 \\
\hline & $\mathrm{K} 1600, \mathrm{~K} 1629, \mathrm{~K} 2286, \mathrm{~K} 2434$ & Q1507 & Q557, Q1932 & Q3083 & Q3056 \\
\hline \multirow[t]{5}{*}{ K3184 } & K3151, K3176, K3177, K3178, & Q1516 & Q127 & Q3156 & Q311, Q1449 \\
\hline & K3179, K3180, K3181, K3182, & Q1532 & Q1063, Q1291 & Q3157 & Q314 \\
\hline & $\mathrm{K} 3183$ & Q1542 & Q1373, Q1374, Q1497, Q1498 & QBWS2 & Q1502, Q1638 \\
\hline & \multirow{2}{*}{ Nassau County } & Q1620 & Q978 & QBWS4 & Q206 \\
\hline & & Q1629 & Q1535 & & Richmond County \\
\hline N3327 & $\mathrm{N} 2578$ & Q1730 & Q451 & & Richmond County \\
\hline N4243 & N3905 & Q1736 & Q1695 & $\mathrm{R} 80$ & RD (tunnel borıng D) \\
\hline N4266 & $\mathrm{N} 2749$ & Q1747 & Q1536 & R94 & R93 \\
\hline
\end{tabular}


Table 8. Observation wells whose records were used to produce maps of water-table and potentiometric-surface altitudes [Upglac, upper glacial, Jam, Jameco Gravel, Mag, Magothy, Bot, bottom]

\begin{tabular}{|c|c|c|c|c|c|c|c|c|c|c|c|c|c|c|c|}
\hline $\begin{array}{c}\text { Well } \\
\text { number }\end{array}$ & \multirow{2}{*}{$\frac{\text { Aquifer }}{\text { Upglac }}$} & \multicolumn{3}{|c|}{$\begin{array}{c}\text { Screened } \\
\text { Interval } \\
\text { (feet above } \\
\text { sea level) }\end{array}$} & \multirow{2}{*}{$\begin{array}{c}\begin{array}{c}\text { Date } \\
\text { measured } \\
\text { (1983) }\end{array} \\
3 / 25\end{array}$} & \multicolumn{2}{|c|}{$\begin{array}{c}\text { Water } \\
\text { level } \\
\text { (feet above } \\
\text { sea level) }\end{array}$} & \multirow{2}{*}{$\begin{array}{c}\begin{array}{c}\text { Well } \\
\text { number }\end{array} \\
\text { Q } 561\end{array}$} & \multirow{2}{*}{$\frac{\text { Aquifer }}{\text { Upglac }}$} & \multicolumn{3}{|c|}{$\begin{array}{c}\text { Screened } \\
\text { interval } \\
\text { (feet above } \\
\text { sea level) }\end{array}$} & \multirow{2}{*}{$\begin{array}{c}\begin{array}{c}\text { Date } \\
\text { measured } \\
\text { (1983) }\end{array} \\
3 / 29\end{array}$} & \multicolumn{2}{|c|}{$\begin{array}{c}\text { Water } \\
\text { level } \\
\text { (feet above } \\
\text { sea level) }\end{array}$} \\
\hline K 19 & & Bot & at & -34 & & 8 & 83 & & & -31 & to & -61 & & 5 & 75 \\
\hline K 30 & Upglac & +8 & to & +3 & $3 / 25$ & 5 & 36 & Q 569 & Upglac & -6 & to & -26 & $3 / 23$ & 0 & 84 \\
\hline K 508 & Upglac & -23 & to & -66 & $3 / 25$ & 9 & 14 & Q 570 & Upglac & -13 & to & -33 & $3 / 23$ & 2 & 92 \\
\hline K 522 & Jam & -188 & to & -248 & $3 / 25$ & 8 & 51 & Q 577 & Lloyd & -485 & to & -520 & $1 / 21$ & -4 & 71 \\
\hline K 631 & Upglac & +16 & to & -9 & $3 / 25$ & 5 & 28 & Q1058 & Upglac & -13 & to & -33 & $3 / 23$ & 1 & 97 \\
\hline K 889 & Upglac & -41 & to & -51 & $3 / 25$ & 3 & 96 & Q1071 & Lloyd & -755 & to & -820 & $1 / 4$ & 1 & 9 \\
\hline K1194 & Upglac & -23 & to & -26 & $3 / 22$ & 7 & 92 & Q1187 & Jam & Bot & at & -120 & $3 / 22$ & 2 & 53 \\
\hline K1265 & Upglac & Bot & at & -21 & $3 / 23$ & 7 & 39 & Q1189 & Upglac & Bot & at & -35 & $3 / 22$ & 1 & 97 \\
\hline K1301 & Upglac & -27 & to & -49 & $3 / 25$ & 5 & 33 & Q1223 & Upglac & Bot & at & -5 & $3 / 23$ & 4 & 40 \\
\hline K1494 & Upglac & -140 & to & -161 & $3 / 25$ & 4 & 21 & Q1237 & Jam & Bot & at & -200 & $3 / 22$ & -0 & 51 \\
\hline K2859 & Lloyd & -464 & to & -480 & $4 / 21$ & 1 & 09 & Q1249 & Upglac & -13 & to & -16 & $3 / 22$ & -5 & 64 \\
\hline K3132 & Jam & -234 & to & -285 & $3 / 25$ & 7 & 22 & Q1250 & Upglac & -14 & to & -17 & $3 / 23$ & -4 & 90 \\
\hline K3245 & Upglac & +9 & to & +6 & $3 / 25$ & 9 & 36 & Q1254 & Upglac & -8 & to & -11 & $3 / 22$ & 3 & 56 \\
\hline K3246 & Upglac & -1 & to & -4 & $3 / 25$ & 8 & 62 & Q1284 & Upglac & Bot & at & -9 & $3 / 23$ & 4 & 43 \\
\hline K3247 & Upglac & -3 & to & -6 & $3 / 25$ & 4 & 06 & Q1326 & Upglac & -13 & to & -45 & $3 / 22$ & 19 & 06 \\
\hline K3248 & Upglac & -7 & to & -10 & $3 / 25$ & 4 & 96 & Q1373 & Lloyd & -144 & to & -156 & $3 / 20$ & 4 & 92 \\
\hline K3249 & Upglac & -11 & to & -14 & $3 / 25$ & 4 & 34 & Q1391 & Upglac & -53 & to & -83 & $3 / 23$ & 14 & 17 \\
\hline K3250 & Upglac & -12 & to & -15 & $3 / 25$ & 1 & 93 & Q1406 & Upglac & -2 & to & -27 & $3 / 23$ & 18 & 17 \\
\hline K3251 & Upglac & -10 & to & -13 & $3 / 25$ & 3 & 04 & Q1416 & Upglac & -2 & to & -27 & $3 / 23$ & 11 & 68 \\
\hline K3252 & Upglac & -11 & to & -14 & $3 / 25$ & 1 & 72 & Q1534 & Upglac & -10 & to & -30 & $3 / 22$ & -4 & 44 \\
\hline K3253 & Upglac & -6 & to & -9 & $3 / 25$ & 5 & 27 & Q1600 & Mag & -172 & to & -192 & $3 / 22$ & -0 & 52 \\
\hline K3254 & Upglac & +1 & to & -2 & $3 / 25$ & 5 & 56 & Q1812 & Mag & -80 & to & -130 & $3 / 22$ & -7 & 74 \\
\hline K3255 & Upglac & -2 & to & -5 & $3 / 25$ & 4 & 70 & Q1829 & Upglac & +19 & to & -13 & $3 / 23$ & 8 & 25 \\
\hline K3256 & Upglac & -1 & to & -4 & $3 / 22$ & 5 & 37 & Q1839 & Upglac & -40 & to & -60 & $3 / 29$ & 5 & 33 \\
\hline K3257 & Upglac & +3 & to & 0 & $3 / 25$ & 12 & 07 & Q1843 & Upglac & -32 & to & -52 & $3 / 23$ & 6 & 05 \\
\hline K3259 & Upglac & +3 & to & 0 & $3 / 25$ & 12 & 38 & Q2006 & Upglac & -36 & to & -56 & $3 / 30$ & -0 & 35 \\
\hline K3260 & Upglac & -7 & to & -10 & $3 / 25$ & 10 & 29 & Q2026 & Mag & -357 & to & -391 & $3 / 29$ & 2 & 31 \\
\hline K3261 & Upglac & +23 & to & +20 & $3 / 25$ & 25 & 81 & Q2137 & Mag & -80 & to & -120 & $3 / 30$ & -5 & 40 \\
\hline K3271 & Upglac & -9 & to & -11 & $3 / 22$ & 5 & 20 & Q2188 & Mag & -124 & to & -164 & $3 / 22$ & 3 & 98 \\
\hline K3272 & Upglac & 0 & to & -3 & $3 / 25$ & 10 & 39 & Q2243 & Mag & -43 & to & -63 & $3 / 29$ & -3 & 45 \\
\hline K3273 & Upglac & -3 & to & -6 & $3 / 25$ & 7 & 99 & Q2275 & Upglac & -31 & to & -51 & $3 / 29$ & -6 & 85 \\
\hline K3274 & Upglac & -4 & to & -7 & $3 / 25$ & 5 & 25 & Q2299 & Upglac & -42 & to & -62 & $3 / 23$ & -9 & 35 \\
\hline K3275 & Upglac & -6 & to & -9 & $3 / 25$ & 4 & 47 & Q2300 & Mag & -125 & to & -165 & $3 / 22$ & -9 & 78 \\
\hline K3276 & Upglac & -13 & to & -16 & $3 / 25$ & 5 & 98 & Q2321 & Upglac & -45 & to & -61 & $3 / 22$ & -1 & 63 \\
\hline Q 34 & $\begin{array}{l}\text { Lloyd } \\
\text { Lloyd }\end{array}$ & -281 & $\begin{array}{l}\text { at } \\
\text { to }\end{array}$ & $\begin{array}{l}-184 \\
-411\end{array}$ & $\begin{array}{l}3 / 22 \\
3 / 22\end{array}$ & 4 & 55 & & & & & & & & \\
\hline Q 273 & Lloyd & -281 & to & -411 & $3 / 22$ & 1 & 51 & Q2343 & Mag & -125 & to & -165 & $3 / 22$ & -1 & 00 \\
\hline Q 283 & Lloyd & -282 & to & -382 & $3 / 22$ & -11 & 59 & Q2346 & Upglac & -15 & to & -17 & $3 / 22$ & 13 & 43 \\
\hline Q 287 & Lloyd & Bot & at & -712 & $1 / 3$ & 0 & 8 & Q2410 & Upglac & -145 & to & -187 & $3 / 22$ & 6 & 69 \\
\hline Q 305 & Upglac & +16 & to & -29 & $3 / 23$ & -12 & 82 & Q2416 & Lloyd & -218 & to & -263 & $1 / 6$ & 5 & 07 \\
\hline & & & & & & & & Q2418 & Upglac & -42 & to & -54 & $3 / 22$ & -0 & 18 \\
\hline Q 306 & Upglac & -16 & to & -46 & $3 / 29$ & 5 & 79 & & & & & & & & \\
\hline Q 307 & Upglac & +17 & to & -27 & $3 / 22$ & -7 & 01 & Q2420 & Lloyd & -218 & to & -268 & $3 / 22$ & 5 & 05 \\
\hline Q 308 & Upglac & +4 & to & -41 & $3 / 30$ & 3 & 37 & Q2422 & Mag & -300 & to & -320 & $3 / 22$ & -1 & 60 \\
\hline Q 313 & Upglac & +34 & to & -9 & $3 / 22$ & -0 & 90 & Q2442 & Upglac & -42 & to & -52 & $3 / 29$ & -4 & 41 \\
\hline Q 319 & Upglac & -8 & to & -23 & $3 / 23$ & 0 & 27 & Q2791 & Upglac & +20 & to & +12 & $3 / 22$ & 53 & 53 \\
\hline & & & & & & & & Q2993 & Upglac & Bot & at & -56 & $4 / 7$ & 7 & 16 \\
\hline Q 321 & Upglac & +13 & to & -2 & $3 / 22$ & 3 & 40 & & & & & & & & \\
\hline Q 324 & Upglac & -13 & to & -33 & $3 / 23$ & 1 & 93 & Q2994 & Upglac & Bot & at & -56 & $3 / 23$ & 3 & 38 \\
\hline Q 470 & Lloyd & -333 & to & -361 & $3 / 23$ & -0 & 07 & Q2995 & Upglac & Bot & at & -73 & $3 / 23$ & 3 & 30 \\
\hline Q 471 & Mag & Bot & at & -98 & $3 / 23$ & 13 & 24 & Q3015 & Mag & -71 & to & -111 & $3 / 22$ & 1 & 76 \\
\hline Q 560 & Upglac & -18 & to & -48 & $3 / 29$ & 6 & 08 & Q3036 & Lloyd & -229 & to & -249 & $1 / 6$ & -7 & 86 \\
\hline & & & & & & & & Q3083 & Mag & -259 & to & -307 & $3 / 29$ & -0 & 17 \\
\hline
\end{tabular}

\footnotetext{
${ }^{1}$ Freshwater equivalent head listed in table 5
} 
Table 8 Observation wells whose records were used to produce maps of water-table and potentıometric-surface altitudesContınued

[Upglac, upper glacial, Jam, Jameco Gravel, Mag, Magothy, Bot, bottom]

\begin{tabular}{|c|c|c|c|c|c|c|c|c|c|c|c|c|c|c|}
\hline \multirow{2}{*}{$\begin{array}{c}\begin{array}{c}\text { Well } \\
\text { number }\end{array} \\
23109\end{array}$} & \multirow{2}{*}{$\begin{array}{l}\text { Aquifer } \\
\text { Mag }\end{array}$} & \multicolumn{3}{|c|}{$\begin{array}{c}\text { Screened } \\
\text { Interval } \\
\text { (feet above } \\
\text { sea level) }\end{array}$} & \multirow{2}{*}{$\begin{array}{c}\begin{array}{c}\text { Date } \\
\text { measured } \\
(\mathbf{1 9 8 3 )}\end{array} \\
3 / 22\end{array}$} & \multirow{2}{*}{$\begin{array}{c}\begin{array}{c}\text { Water } \\
\text { level } \\
\text { (feet above } \\
\text { sea level) }\end{array} \\
{ }^{1} 150\end{array}$} & \multirow{2}{*}{$\begin{array}{c}\begin{array}{c}\text { Well } \\
\text { number }\end{array} \\
\text { N3861 }\end{array}$} & \multirow{2}{*}{$\begin{array}{l}\text { Aquifer } \\
\text { Mag }\end{array}$} & \multicolumn{3}{|c|}{$\begin{array}{c}\text { Screened } \\
\text { Interval } \\
\text { (feet above } \\
\text { sea level) }\end{array}$} & \multirow{2}{*}{$\begin{array}{c}\begin{array}{c}\text { Date } \\
\text { measured } \\
\text { (1983) }\end{array} \\
3 / 22\end{array}$} & \multicolumn{2}{|c|}{$\begin{array}{c}\text { Water } \\
\text { level } \\
\text { (feet above } \\
\text { sea level) }\end{array}$} \\
\hline & & -268 & to & -288 & & & & & -512 & to & -523 & & ${ }^{1}-4$ & 60 \\
\hline Q3110 & Jam & -296 & to & -316 & $3 / 22$ & ${ }^{1} 239$ & N3862 & Mag & -288 & to & -299 & $3 / 28$ & ${ }^{1} 3$ & 28 \\
\hline \multirow[t]{2}{*}{ Q3112 } & Jam & -199 & to & -209 & & & N3864 & Mag & -456 & to & -467 & $3 / 28$ & 4 & 28 \\
\hline & & -279 & to & -289 & $3 / 21$ & 103 & N3867 & Mag & -497 & to & -509 & $3 / 23$ & 1 & 06 \\
\hline Q3114 & Upglac & -7 & to & -9 & $3 / 23$ & 336 & N3905 & Mag & -80 & to & -120 & $3 / 9$ & 33 & 00 \\
\hline \multirow[t]{2}{*}{ Q3115 } & Upglac & Bot & at & -16 & $3 / 23$ & 405 & & & & & & & & \\
\hline & & & & & & & $\mathrm{N} 4213$ & Jam & -125 & to & -129 & $3 / 28$ & 1 & 10 \\
\hline Q3117 & Upglac & Bot & at & -12 & $3 / 23$ & 308 & N4266 & Lloyd & -317 & to & -337 & $3 / 23$ & 0 & 90 \\
\hline Q3118 & Upglac & -10 & to & -13 & $3 / 23$ & 268 & N5156 & Mag & -220 & to & -260 & $3 / 29$ & 16 & 20 \\
\hline Q3119 & Upglac & +4 & to & +05 & $3 / 22$ & 1887 & N6242 & Upglac & -3 & to & -5 & $3 / 28$ & 3 & 15 \\
\hline Q3121 & Upglac & +6 & to & +3 & $3 / 22$ & 2299 & N6510 & Mag & -444 & to & -450 & $3 / 28$ & ${ }^{\prime}-3$ & 21 \\
\hline Q3122 & Upglac & -3 & to & -6 & $3 / 22$ & 1173 & & & & & & & & \\
\hline & & & & & & & $\mathrm{N} 6702$ & Mag & -655 & to & -666 & $3 / 22$ & ${ }^{1}-5$ & 19 \\
\hline Q3123 & Upglac & +1 & to & -2 & $3 / 22$ & 668 & N6703 & Mag & -456 & to & -467 & $3 / 22$ & ${ }^{1} 1$ & 73 \\
\hline Q3150 & Jam & Bot & at & -119 & $4 / 21$ & ${ }^{1} 161$ & N6707 & Mag & -487 & to & -497 & $3 / 28$ & 3 & 20 \\
\hline & & & & & & & N7235 & Upglac & -18 & to & -20 & $4 / 4$ & 5 & 73 \\
\hline 9 & Mag & -74 & to & -114 & $3 / 22$ & 595 & N7445 & Mag & -263 & to & -323 & $3 / 30$ & 33 & 29 \\
\hline $\mathrm{N} \quad 22$ & Mag & -110 & to & -130 & $3 / 3$ & 001 & & & & & & & & \\
\hline N 24 & Lloyd & -347 & to & -407 & $1 / 12$ & 132 & N7472 & Mag & -112 & to & -116 & $3 / 21$ & 4 & 23 \\
\hline N 700 & Upglac & +4 & to & -20 & $3 / 18$ & 116 & N7493 & Mag & -274 & to & -278 & $3 / 23$ & 4 & 08 \\
\hline N1102 & Upglac & +23 & to & +18 & $3 / 23$ & 2899 & N7512 & Mag & -202 & to & -252 & $3 / 9$ & 36 & 00 \\
\hline & & & & & & & N7720 & Mag & -366 & to & -437 & $3 / 8$ & 29 & 16 \\
\hline N1106 & Upglac & +16 & to & +13 & $4 / 6$ & 2463 & N7855 & Mag & -493 & to & -563 & $3 / 10$ & 6 & 02 \\
\hline N1108 & Upglac & +4 & to & +1 & $4 / 6$ & 1661 & & & & & & & & \\
\hline N1110 & Upglac & Bot & at & -4 & $4 / 6$ & 790 & N8011 & Lloyd & $-1,199$ & to & $-1,259$ & $1 / 5$ & 0 & 66 \\
\hline N1111 & Upglac & Bot & at & -7 & $4 / 6$ & 806 & N8038 & Mag & -61 & to & -85 & $3 / 9$ & 33 & 40 \\
\hline N1112 & Upglac & -7 & to & -10 & $4 / 4$ & 618 & N8052 & Upglac & -78 & to & -82 & $3 / 18$ & 3 & 38 \\
\hline & & & & & & & N8195 & Mag & -426 & to & -486 & $3 / 10$ & -7 & 33 \\
\hline N1114 & Upglac & -2 & to & -5 & $4 / 4$ & 944 & N8374 & Upglac & -9 & to & -12 & $4 / 8$ & 1 & 99 \\
\hline N1115 & Upglac & +7 & to & +3 & $4 / 4$ & 989 & & & & & & & & \\
\hline N1116 & Upglac & -9 & to & -12 & $4 / 4$ & 497 & N8599 & Upglac & -11 & to & -15 & $4 / 4$ & 3 & 65 \\
\hline N1298 & Lloyd & -271 & to & -321 & $1 / 6$ & $\begin{array}{ll}-0 & 15\end{array}$ & N8638 & Upglac & -21 & to & -24 & $4 / 4$ & 3 & 50 \\
\hline N1328 & Lloyd & -475 & to & -565 & $1 / 12$ & 009 & N8644 & Upglac & -3 & to & -6 & $4 / 4$ & 7 & 17 \\
\hline & & & & & & & N8646 & Upglac & -14 & to & -16 & $4 / 4$ & 2 & 73 \\
\hline N1422 & Upglac & Bot & at & -13 & $4 / 4$ & 809 & N8655 & Upglac & -17 & to & -20 & $4 / 4$ & 1 & 98 \\
\hline N1427 & Upglac & Bot & at & +9 & $4 / 8$ & 1299 & & & & & & & & \\
\hline N1429 & Upglac & Bot & at & -8 & $4 / 4$ & 816 & N8964 & Upglac & -38 & to & -43 & $3 / 18$ & 14 & 8 \\
\hline N1453 & Upglac & +27 & to & +24 & $4 / 6$ & 2385 & N8970 & Upglac & -34 & to & -39 & $4 / 6$ & 23 & 22 \\
\hline N1455 & Upglac & +18 & to & +15 & $4 / 6$ & 1948 & N9098 & Upglac & -8 & to & -13 & $4 / 5$ & 16 & 74 \\
\hline & & & & & & & N9099 & Upglac & -6 & to & -11 & $3 / 23$ & 15 & 37 \\
\hline N1458 & Upglac & +10 & to & +7 & $4 / 6$ & $18 \quad 02$ & N9188 & Upglac & -30 & to & -35 & $4 / 6$ & 25 & 49 \\
\hline N1459 & Upglac & +10 & to & +7 & $4 / 5$ & 1482 & & & & & & & & \\
\hline N1472 & Upglac & Bot & at & +19 & $4 / 6$ & 2876 & N9208 & Upglac & -73 & to & -78 & $3 / 23$ & 13 & 75 \\
\hline N1475 & Upglac & +19 & to & +16 & $4 / 6$ & 2744 & N9309 & Upglac & -11 & to & -16 & $3 / 23$ & 8 & 40 \\
\hline N1613 & Mag & Bot & at & -471 & $3 / 21$ & 364 & N9468 & Upglac & -14 & to & -18 & $4 / 4$ & 5 & 38 \\
\hline & & & & & & & N9476 & Upglac & -14 & to & -19 & $4 / 8$ & 3 & 13 \\
\hline N1625 & Upglac & +2 & to & -1 & $4 / 8$ & 285 & N9776 & Lloyd & -237 & to & -248 & $1 / 6$ & -1 & 77 \\
\hline N1 626 & Upglac & -4 & to & -7 & $4 / 8$ & 454 & & & & & & & & \\
\hline N1628 & Upglac & -10 & to & -14 & $4 / 4$ & .303 & N9820 & Lloyd & -239 & to & -244 & $1 / 6$ & 7 & 58 \\
\hline N1682 & Upglac & -18 & to & -21 & $4 / 8$ & 1555 & N9892 & Upglac & -3 & to & -13 & $3 / 18$ & 9 & 8 \\
\hline N1683 & Upglac & Bot & at & +25 & $4 / 8$ & 3240 & N9893 & Upglac & -1 & to & -11 & $3 / 18$ & 3 & 50 \\
\hline & & & & & & & N9895 & Upglac & +3 & to & -7 & $3 / 18$ & 17 & 50 \\
\hline N1802 & Lloyd & -509 & to & -559 & $1 / 12$ & -491 & N994 7 & Upglac & -19 & to & -24 & $4 / 8$ & 12 & 02 \\
\hline N2413 & Mag & -427 & to & -457 & $3 / 29$ & 765 & & & & & & & & \\
\hline N3707 & Upglac & -7 & to & -9 & $4 / 4$ & 241 & N9979 & Upglac & Bot & at & -19 & $4 / 8$ & 5 & 39 \\
\hline N3708 & Upglac & -10 & to & -13 & $4 / 4$ & 111 & N9982 & Upglac & -104 & to & -109 & $4 / 6$ & 32 & 82 \\
\hline N3710 & Upglac & -0 & to & -12 & $4 / 4$ & 171 & N9983 & Upglac & +16 & to & +11 & $4 / 6$ & 32 & 39 \\
\hline & & & & & & & N10005 & Upglac & -10 & to & -15 & $4 / 8$ & 8 & 17 \\
\hline
\end{tabular}

${ }^{\mathrm{l}}$ Freshwater equivalent head listed in table 5 
8 Table 9 Hydrogeologic units penetrated by wells and test holes in Kıngs, Queens, Nassau, Bronx, New York, and Richmond Counties, New York

[Well locations are shown on plate 1, PRES, unit present but surface altıtude not discernıble, NR, no record-no record near altitudes indicated under remarks, Veatch, well number from numberıng system employed in Veatch and others, 1906, BWS, New York City Bureau of Water Supply Well, 20ft, "20 foot" clay may be present]

\begin{tabular}{|c|c|c|c|c|c|c|c|c|c|c|c|c|c|}
\hline \multirow{3}{*}{\multicolumn{2}{|c|}{$\begin{array}{c}\text { Well } \\
\text { Identification } \\
\text { number }\end{array}$}} & \multirow[b]{3}{*}{ Latitude } & \multirow[b]{3}{*}{ Longitude } & \multirow{2}{*}{\multicolumn{2}{|c|}{$\begin{array}{l}\text { Altitude of well, } \\
\text { in feet above or } \\
\text { below sea level }\end{array}$}} & \multicolumn{6}{|c|}{$\begin{array}{l}\text { Hydrogeologic unit penetrated and altitude of } \\
\text { unit surface, in feet above or below sea level }\end{array}$} & \multirow{3}{*}{$\begin{array}{c}\text { Located } \\
\text { near well }\end{array}$} & \multirow[b]{3}{*}{ Remarks } \\
\hline & & & & & & \multirow{2}{*}{$\begin{array}{c}\text { Gardiners } \\
\text { Clay }\end{array}$} & \multirow{2}{*}{$\begin{array}{c}\text { Jameco } \\
\text { Gravel }\end{array}$} & \multirow{2}{*}{$\begin{array}{c}\text { Magothy } \\
\text { aquifer }\end{array}$} & \multirow{2}{*}{$\begin{array}{c}\text { Raritan } \\
\text { confınıng unit } \\
\end{array}$} & \multirow{2}{*}{$\begin{array}{l}\text { Lloyd } \\
\text { aquifer }\end{array}$} & \multirow[b]{2}{*}{ Bedrock } & & \\
\hline & & & & Top & Bottom & & & & & & & & \\
\hline B & 1 & 404826 & 735000 & 2 & & & & & & & -63 & & \\
\hline B & 2 & 404817 & 734958 & 0 & & & & & & & -98 & & \\
\hline B & 3 & 404852 & 734909 & 9 & & & & & & & -50 & & \\
\hline B & 4 & 405130 & 734616 & 10 & & & & & & & -2 & & \\
\hline B & 39 & 404831 & 735005 & 2 & -90 & & & & & & -63 & & \\
\hline B & 59 & 404820 & 735249 & 8 & -80 & & & & & & -70 & & \\
\hline B & 69 & 404845 & 735210 & 0 & -76 & & & & & & -71 & & \\
\hline M & 41 & 404240 & 740029 & 30 & -46 & & & & & & -46 & & \\
\hline M & 114 & 404236 & 740037 & 30 & -47 & & & & & & -47 & & \\
\hline M & 160 & 404705 & 735635 & 3 & -146 & & & & & & -139 & & \\
\hline M & 161 & 404432 & 735915 & 30 & 7 & & & & & & 16 & & \\
\hline $\mathrm{R}$ & A & 403614 & 740310 & 0 & -210 & -124 & -170 & & & & -190 & & Bridge boring \\
\hline $\mathrm{R}$ & B & 403609 & 740326 & 90 & -216 & -99 & & & & & -163 & & Bridge boring \\
\hline $\mathrm{R}$ & C & 403834 & 740413 & & & & & & & & -115 & & Tunnel boring \\
\hline $\mathrm{R}$ & $\mathrm{D}$ & 403831 & 740440 & & & & & & & & 100 & $\mathrm{R} 80$ & Tunnel boring \\
\hline $\mathrm{R}$ & 7 & 403753 & 740437 & 10 & -40 & & & & & & & & \\
\hline $\mathrm{R}$ & 14 & 403734 & 740445 & 25 & -18 & & & & & & & & \\
\hline $\mathrm{R}$ & 18 & 403659 & 740416 & 45 & -97 & & & & & & & & \\
\hline $\mathrm{R}$ & 22 & 403700 & 740358 & 15 & -162 & & & & & & -162 & & \\
\hline $\mathrm{R}$ & 65 & 403506 & 740538 & 10 & -77 & & & & -75 & & & & \\
\hline $\mathrm{R}$ & 66 & 403529 & 740518 & 12 & -87 & & & & -84 & & & & \\
\hline $\mathrm{R}$ & 73 & 403730 & 740449 & 50 & -30 & & & & & & -30 & & \\
\hline $\mathrm{R}$ & 79 & 403815 & 740519 & 120 & 76 & & & & & & 110 & & \\
\hline $\mathrm{R}$ & 80 & 403830 & 740441 & 110 & 73 & & & & & & 106 & & \\
\hline $\mathrm{R}$ & 81 & 403831 & 740433 & 40 & -9 & & & & & & 6 & & \\
\hline $\mathrm{R}$ & 82 & 403443 & 740316 & 5 & $-1,000$ & & & $\mathrm{NR}$ & $\mathrm{NR}$ & $\mathrm{NR}$ & -450 & & \\
\hline $\mathrm{R}$ & 89 & 403659 & 740409 & 25 & -11 & & & & & & & & \\
\hline $\mathrm{R}$ & 91 & 403652 & 740404 & 25 & -15 & & & & & & & & \\
\hline R & 93 & 403646 & 740359 & 25 & -27 & & & & & & & R94 & \\
\hline R & 94 & 403643 & 740357 & 25 & -34 & & & & & & & & \\
\hline $\mathrm{R}$ & 95 & 403638 & 740353 & 35 & -33 & & & & & & & & \\
\hline $\mathrm{R}$ & 98 & 403628 & 740331 & 55 & -88 & & & & & & & & \\
\hline $\mathrm{R}$ & 99 & 403632 & 740325 & 0 & -114 & & & & & & & & \\
\hline $\mathrm{R}$ & 100 & 403639 & 740307 & 0 & -122 & & & & & & & & \\
\hline K & A & 403630 & 740220 & 0 & -275 & -105 & -170 & & -183 & & -270 & & \\
\hline
\end{tabular}


Table 9 Hydrogeologic units penetrated by wells and test holes in Kıngs, Queens, Nassau, Bronx, New York, and Rıchmond Countıes, New York-Contınued [Well locations are shown on plate 1, PRES, unit present but surface altitude not discernible, NR, no record-no record near altitudes indicated under remarks, Veatch, well number from numbering system employed in Veatch and others, 1906, BWS, New York City Bureau of Water Supply Well, 20ft, "20 foot" clay may be present]

\begin{tabular}{|c|c|c|c|c|c|c|c|c|c|c|c|c|c|}
\hline \multirow{3}{*}{\multicolumn{2}{|c|}{$\begin{array}{c}\text { Well } \\
\text { Identification } \\
\text { number }\end{array}$}} & \multirow[b]{3}{*}{ Latitude } & \multirow[b]{3}{*}{ Longitude } & \multirow{2}{*}{\multicolumn{2}{|c|}{$\begin{array}{l}\text { Altitude of well, } \\
\text { in feet above or } \\
\text { below sea level }\end{array}$}} & \multicolumn{6}{|c|}{$\begin{array}{l}\text { Hydrogeologic unit penetrated and altitude of } \\
\text { unit surface, in feet above or below sea level }\end{array}$} & \multirow{3}{*}{$\begin{array}{c}\text { Located } \\
\text { near well }\end{array}$} & \multirow[b]{3}{*}{ Remarks } \\
\hline & & & & & & \multirow{2}{*}{$\begin{array}{c}\text { Gardiners } \\
\text { Clay }\end{array}$} & \multirow{2}{*}{$\begin{array}{c}\text { Jameco } \\
\text { Gravel }\end{array}$} & \multirow{2}{*}{$\begin{array}{c}\text { Magothy } \\
\text { aquifer }\end{array}$} & \multirow{2}{*}{$\begin{array}{c}\text { Raritan } \\
\text { confining unit }\end{array}$} & \multirow{2}{*}{$\begin{array}{c}\text { Lloyd } \\
\text { aquifer }\end{array}$} & \multirow[b]{2}{*}{ Bedrock } & & \\
\hline & & & & Top & Bottom & & & & & & & & \\
\hline K & 1 & 403441 & 735917 & 5 & -745 & -150 & -163 & -229 & -393 & -471 & -625 & & \\
\hline $\mathrm{K}$ & 9 & 404027 & 735945 & 4 & -155 & -91 & -125 & & & & -145 & & \\
\hline $\mathrm{K}$ & 12 & 404150 & 735912 & 49 & -50 & & & & & & -50 & & \\
\hline $\mathrm{K}$ & 15 & 404148 & 735852 & 15 & -99 & & & & & & -93 & & \\
\hline K & 20 & 404054 & 735824 & 40 & -96 & -94 & & & & & & & \\
\hline $\mathrm{K}$ & 23 & 404055 & 735759 & 57 & -186 & & & & & & -186 & & \\
\hline $\mathrm{K}$ & 33 & 404204 & 735708 & 14 & -162 & -82 & -131 & & & & & K2069 & \\
\hline $\mathrm{K}$ & 36 & 404208 & 735602 & 28 & -80 & -77 & & & & & & & \\
\hline $\mathrm{K}$ & 37 & 404228 & 735623 & 25 & -105 & -92 & & & & & & $\mathrm{~K} 1490$ & \\
\hline $\mathrm{K}$ & 45 & 404048 & 735411 & 61 & -223 & -155 & & & & & & & \\
\hline $\mathrm{K}$ & 49 & 404317 & 735725 & 18 & -315 & -82 & & & & & -114 & $\mathrm{~K} 1112$ & \\
\hline $\mathrm{K}$ & 50 & 404314 & 735728 & 16 & -141 & -75 & & & & & -141 & & \\
\hline $\mathrm{K}$ & 642 & 404201 & 735654 & 10 & -158 & -85 & -99 & & & & & K3133 & \\
\hline $\mathrm{K}$ & 645 & 404202 & 735655 & 10 & -155 & -58 & -90 & & & & & K3133 & \\
\hline K & 646 & 404202 & 735655 & 10 & -164 & -67 & -130 & & & & & $\mathrm{~K} 31$ & \\
\hline $\mathrm{K}$ & 82 & 404147 & 735802 & 20 & -100 & & & & & & -100 & K1548 & $\begin{array}{llll}\text { NR } & 20 & \text { TO } & -99\end{array}$ \\
\hline $\mathrm{K}$ & 110 & 404154 & 735943 & 72 & -88 & & & & & & -88 & & \\
\hline $\mathrm{K}$ & 167 & 403918 & 740038 & 13 & -137 & -73 & -82 & & & & & $\mathrm{~K} 1148$ & \\
\hline $\mathrm{K}$ & 178 & 403420 & 735925 & 5 & -113 & & & & & & & K1558 & \\
\hline $\mathrm{K}$ & 247 & 403813 & 735351 & 15 & -164 & & & & & & & & \\
\hline $\mathrm{K}$ & 249 & 404132 & 735643 & 40 & -135 & -133 & & & & & & & \\
\hline $\mathrm{K}$ & 255 & 404150 & 735613 & 54 & -69 & -69 & & & & & & & \\
\hline $\mathrm{K}$ & 256 & 404126 & 735725 & 50 & -156 & -124 & & & & & -156 & & \\
\hline $\mathrm{K}$ & 259 & 404120 & 735859 & 40 & -73 & -73 & & & & & & K320 & \\
\hline K & 261 & 404126 & 735916 & 35 & -60 & & & & & & -60 & & \\
\hline $\mathrm{K}$ & 277 & 404118 & 735854 & 37 & -109 & -86 & & & & & -109 & K320 & \\
\hline $\mathrm{K}$ & 283 & 403432 & 735855 & 7 & -147 & & & & & & & & \\
\hline $\mathrm{K}$ & 285 & 403804 & 735946 & 63 & -149 & -144 & & & & & & & \\
\hline K & 290 & 404117 & 735900 & 39 & -65 & & & & & & -65 & K656 & . \\
\hline K & 316 & 403747 & 740121 & 65 & -129 & -125 & & & & & & & \\
\hline $\mathrm{K}$ & 320 & 404119 & 735857 & 38 & -76 & -65 & & & & & -75 & & \\
\hline $\mathrm{k}$ & 329 & 403952 & 735555 & 75 & -158 & -90 & -128 & & & & & & \\
\hline $\mathrm{K}$ & 426 & 404231 & 735633 & 38 & -102 & -64 & & & & & & & \\
\hline $\mathrm{K}$ & 458 & 404253 & 735802 & 5 & $-1,048$ & -115 & & & & & -173 & & \\
\hline K & 464 & 403643 & 735452 & 5 & -489 & -159 & -202 & -245 & -284 & -443 & & & \\
\hline
\end{tabular}


\& Table 9. Hydrogeologic units penetrated by wells and test holes in Kıngs, Queens, Nassau, Bronx, New York, and Richmond Counties, New York-Contınued [Well locations are shown on plate 1, PRES, unit present but surface altitude not discermble, NR, no record-no record near altitudes indicated under remarks, Veatch, well number from numbering system employed in Veatch and others, 1906, BWS, New York City Bureau of Water Supply Well, $20 \mathrm{ft}$, "20 foot" clay may be present]

\begin{tabular}{|c|c|c|c|c|c|c|c|c|c|c|c|c|c|}
\hline \multirow{2}{*}{\multicolumn{2}{|c|}{$\begin{array}{c}\text { Well } \\
\text { Identification } \\
\text { number }\end{array}$}} & \multirow[b]{2}{*}{ Latutude } & \multirow[b]{2}{*}{ Longitude } & \multicolumn{2}{|c|}{$\begin{array}{l}\text { Altitude of well, } \\
\text { In feet above or } \\
\text { below sea level }\end{array}$} & \multicolumn{6}{|c|}{$\begin{array}{l}\text { Hydrogeologic unit penetrated and altitude of } \\
\text { unit surface, in feet above or below sea level }\end{array}$} & \multirow[b]{2}{*}{$\begin{array}{c}\text { Located } \\
\text { near well }\end{array}$} & \multirow[b]{2}{*}{ Remarks } \\
\hline & & & & belov & $\frac{\text { level }}{\text { Bottom }}$ & $\begin{array}{c}\text { Gardıners } \\
\text { Clay } \\
\end{array}$ & $\begin{array}{l}\text { Jameco } \\
\text { Gravel }\end{array}$ & $\begin{array}{c}\text { Magothy } \\
\text { aquifer }\end{array}$ & $\begin{array}{c}\text { Raritan } \\
\text { confining unit }\end{array}$ & $\begin{array}{l}\text { Lloyd } \\
\text { aquifer }\end{array}$ & Bedrock & & \\
\hline K & 465 & 404411 & 735706 & 10 & -390 & & & & & & -55 & & \\
\hline $\mathrm{K}$ & 514 & 403830 & 735545 & 26 & -534 & -149 & -167 & & -198 & PRES & -441 & & \\
\hline $\mathrm{K}$ & 515 & 403819 & 735624 & 20 & -323 & -146 & -180 & & -197 & -278 & & & ' \\
\hline K & 517 & 403950 & 735709 & 78 & -225 & -100 & -165 & & PRES & & & & \\
\hline K & 518 & 403815 & 735617 & 13 & -317 & -157 & -184 & & -215 & -287 & & & \\
\hline $\mathrm{K}$ & 519 & 403936 & 735613 & 29 & -221 & -131 & -157 & & PRES & & & & \\
\hline $\mathrm{K}$ & 520 & 403951 & 735525 & 42 & -376 & -98 & -131 & & -268 & -288 & -358 & K533 & \\
\hline $\mathrm{K}$ & 521 & 403849 & 735547 & 34 & -396 & -136 & -179 & & -223 & -323 & & & \\
\hline $\mathrm{K}$ & 522 & 403857 & 735721 & 50 & -250 & -91 & -145 & & -240 & & & & \\
\hline K & 523 & 403754 & 735813 & 47 & -488 & -123 & -153 & & -204 & -248 & -384 & & \\
\hline K & 524 & 403920 & 735551 & 33 & -357 & -146 & -198 & & -254 & -331 & -349 & & \\
\hline $\mathrm{K}$ & 525 & 403818 & 735847 & 47 & -353 & -173 & -217 & & -260 & -288 & & & \\
\hline K & 526 & 403949 & 735737 & 82 & -318 & -146 & -211 & & & & -289 & K531 & \\
\hline $\mathrm{K}$ & 528 & 403921 & 735708 & 61 & -310 & -172 & -195 & & -237 & & -310 & & \\
\hline K & 529 & 403839 & 735847 & 62 & -158 & -151 & & & & & & & \\
\hline $\mathrm{K}$ & 530 & 403818 & 735810 & 33 & -127 & -112 & & & & & & & \\
\hline K & 531 & 403950 & 735740 & 82 & -296 & -146 & -214 & & & & -291 & & \\
\hline K & 532 & 403819 & 735654 & 11 & -454 & -146 & -178 & & -199 & -264 & -409 & & \\
\hline K & 533 & 403954 & 735523 & 42 & -353 & -98 & -131 & & -268 & -288 & -342 & & \\
\hline K & 534 & 403819 & 735644 & 17 & -452 & -150 & PRES & & PRES & -273 & -404 & & \\
\hline K & 537 & 403851 & 735452 & 19 & -194 & -128 & -164 & & & & & & \\
\hline $\mathrm{K}$ & 538 & 404015 & 735227 & 10 & -162 & -60 & -112 & & & & & KI286 & \\
\hline $\mathrm{K}$ & 543 & 404107 & 735259 & 63 & -222 & -154 & -218 & & & & & & \\
\hline $\mathrm{K}$ & 569 & 404304 & 735600 & 15 & -175 & -33 & & & PRES & & & & Veatch 65 \\
\hline K & 579 & 404351 & 735635 & 7 & -75 & & & & & & -75 & & \\
\hline K & 584 & 403742 & 740126 & 60 & -85 & -70 & & & & & & & \\
\hline $\mathrm{k}$ & 611 & 404215 & 735805 & 10 & -120 & -92 & & & & & & & Veatch 55 \\
\hline K & 619 & 403929 & 735357 & 25 & -426 & -101 & -120 & & -206 & -349 & -426 & & \\
\hline $\mathrm{K}$ & 637 & 404226 & 735641 & 35 & -177 & -55 & & & -114 & & -168 & K2533 & \\
\hline $\mathrm{K}$ & 638 & 404022 & 735937 & 9 & -166 & -135 & -136 & & & & -166 & $\mathrm{~K} 1332$ & \\
\hline & 639 & 404009 & 735940 & 28 & -162 & -122 & -142 & & & & & K1010 & \\
\hline & 401 & 404209 & 740021 & & & & & & & & -33 & $\mathrm{~K} 6404$ & NR TO -33 \\
\hline K6 & 402 & 404202 & 740015 & & & & & & & & -46 & $K 6404$ & NR TO -46 \\
\hline & 403 & 404200 & 740013 & & & & & & & & -50 & K640 4 & NR TO -50 \\
\hline K6 & 404 & 404157 & 740010 & & & & & & & & -68 & & NR TO -68 \\
\hline
\end{tabular}


Table 9. Hydrogeologıc unıts penetrated by wells and test holes in Kıngs, Queens, Nassau, Bronx, New York, and Rıchmond Countıes, New York-Contınued [Well locations are shown on plate 1, PRES, unit present but surface altitude not discernible, NR, no record-no record near alttudes indicated under remarks, Veatch, well number from numberng system employed in Veatch and others, 1906, BWS, New York City Bureau of Water Supply Well, 20ft, "20 foot" clay may be present]

\begin{tabular}{|c|c|c|c|c|c|c|c|c|c|c|c|c|c|}
\hline \multirow{2}{*}{\multicolumn{2}{|c|}{$\begin{array}{c}\text { Well } \\
\text { Identıfication } \\
\text { number }\end{array}$}} & \multirow[b]{2}{*}{ Latıtude } & \multirow[b]{2}{*}{ Longitude } & \multicolumn{2}{|c|}{$\begin{array}{l}\text { Altıtude of well, } \\
\text { in feet above or } \\
\text { below sea level }\end{array}$} & \multicolumn{6}{|c|}{$\begin{array}{l}\text { Hydrogeologic unit penetrated and altitude of } \\
\text { unit surface, in feet above or below sea level }\end{array}$} & \multirow[b]{2}{*}{$\begin{array}{l}\text { Located } \\
\text { near well }\end{array}$} & \multirow[b]{2}{*}{ Remarks } \\
\hline & & & & $\begin{array}{l}\text { belov } \\
\text { Top }\end{array}$ & $\frac{\text { level }}{\text { Bottom }}$ & $\begin{array}{c}\text { Gardıners } \\
\text { Clay }\end{array}$ & $\begin{array}{c}\text { Jameco } \\
\text { Gravel }\end{array}$ & $\begin{array}{c}\text { Magothy } \\
\text { aquifer }\end{array}$ & $\begin{array}{c}\text { Raritan } \\
\text { confınıng unit }\end{array}$ & $\begin{array}{l}\text { Lloyd } \\
\text { aquifer }\end{array}$ & Bedrock & & \\
\hline $\mathrm{K}$ & 641 & 404210 & 740009 & & & & & & & & -64 & & NR TO -64 \\
\hline & 421 & 404211 & 735957 & & & & & & & & -92 & K642 2 & NR TO -92 \\
\hline & 422 & 404218 & 740003 & & & & & & & & -92 & & NR TO -92 \\
\hline $\mathrm{K}$ & 646 & 404021 & 735909 & 25 & -169 & -82 & -129 & & & & & & \\
\hline K & 648 & 404019 & 735915 & 38 & -159 & -112 & -114 & & & & & & \\
\hline $\mathrm{K}$ & 650 & 404015 & 735918 & 40 & -155 & -81 & -122 & & & & & & \\
\hline K & 654 & 404102 & 735933 & 25 & -133 & & & & & & -100 & & \\
\hline $\mathrm{K}$ & 655 & 404109 & 735859 & 39 & -175 & & & & & & -147 & & \\
\hline $\mathrm{K}$ & 656 & 404115 & 735856 & 43 & -116 & & & & & & -90 & & \\
\hline K & 657 & 404055 & 735838 & 44 & -183 & & & & & & -162 & & \\
\hline K & 658 & 404135 & 735809 & 61 & -140 & -103 & & & & & -120 & & \\
\hline K & 659 & 404111 & 735846 & 38 & -132 & & & & & & -106 & & \\
\hline K & 660 & 404119 & 735853 & 35 & -90 & & & & & & -67 & K1073 & \\
\hline $\mathrm{K}$ & 661 & 404130 & 735840 & 54 & -94 & -71 & & & & & -74 & & \\
\hline $\mathrm{k}$ & 662 & 404216 & 735924 & 0 & -108 & & & & & & -98 & & \\
\hline $\mathrm{K}$ & 663 & 404152 & 735813 & 14 & -181 & PRES & & & & & -161 & & \\
\hline $\mathrm{K}$ & 664 & 404207 & 735748 & 17 & -162 & -104 & & & & & -142 & & \\
\hline K & 665 & 404147 & 735831 & 12 & -157 & -108 & & & & & -140 & & \\
\hline $\mathrm{K}$ & 666 & 404217 & 735733 & 55 & -159 & & & & & & -139 & & \\
\hline K & 668 & 404054 & 735947 & 57 & -142 & & & & & & -123 & & \\
\hline $\mathrm{K}$ & 669 & 404049 & 740001 & 48 & -134 & & & & & & -114 & & \\
\hline $\mathrm{K}$ & 670 & 404228 & 735718 & 30 & -135 & & & & -75 & & -115 & & \\
\hline $\mathrm{K}$ & 671 & 404209 & 735906 & 37 & -98 & & & & & & -76 & & \\
\hline $\mathrm{K}$ & 672 & 404238 & 735715 & 20 & -150 & & & & -74 & & -130 & & \\
\hline $\mathrm{K}$ & 673 & 404249 & 735708 & 14 & -182 & & & & -98 & & -161 & K898 & \\
\hline $\mathrm{K}$ & 675 & 404307 & 735545 & 13 & -209 & & & & PRES & & -190 & K1977 & \\
\hline $\mathrm{K}$ & 676 & 404108 & 735910 & 28 & -135 & & & & & & -127 & K731 & \\
\hline $\mathrm{K}$ & 677 & 404300 & 735613 & 19 & -196 & -30 & & & -69 & & -176 & & \\
\hline K & 678 & 404253 & 735635 & 39 & -182 & & & & -46 & & -162 & & \\
\hline K & 679 & 404321 & 735628 & 35 & -183 & & & & -47 & & -163 & & \\
\hline $\mathrm{K}$ & 680 & 403959 & 735220 & 5 & -429 & -105 & -151 & -211 & -229 & -408 & & & \\
\hline $\mathrm{K}$ & 682 & 404400 & 735737 & 10 & -43 & & & & & & -43 & & \\
\hline $\mathrm{K}$ & 684 & 404212 & 735940 & 5 & -99 & & & & & & -98 & & \\
\hline $\mathrm{K}$ & 685 & 404216 & 735913 & 7 & -84 & & & & & & -73 & & \\
\hline K & 686 & 404241 & 735810 & 0 & -146 & & & & & & -146 & & \\
\hline
\end{tabular}


Table 9 Hydrogeologıc units penetrated by wells and test holes in Kıngs, Queens, Nassau, Bronx, New York, and Rıchmond Counties, New York-Contınued [Well locations are shown on plate 1, PRES, unit present but surface alttude not discernble, NR, no record—no record near alttudes indicated under remarks, Veatch, well number from numbering system

\begin{tabular}{|c|c|c|c|c|c|c|c|c|c|c|c|c|c|}
\hline \multirow{2}{*}{\multicolumn{2}{|c|}{$\begin{array}{c}\text { Well } \\
\text { Identificatıon } \\
\text { number }\end{array}$}} & \multirow[b]{2}{*}{ Latitude } & \multirow[b]{2}{*}{ Longitude } & \multicolumn{2}{|c|}{$\begin{array}{l}\text { Altitude of well, } \\
\text { in feet above or } \\
\text { below sea level }\end{array}$} & \multicolumn{6}{|c|}{$\begin{array}{l}\text { Hydrogeologic unit penetrated and altitude of } \\
\text { unit surface, in feet above or below sea level }\end{array}$} & \multirow[b]{2}{*}{$\begin{array}{l}\text { Located } \\
\text { near well }\end{array}$} & \multirow[b]{2}{*}{ Remarks } \\
\hline & & & & $\begin{array}{l}\text { belov } \\
\text { Top } \\
\end{array}$ & $\frac{\text { level }}{\text { Bottom }}$ & $\begin{array}{c}\text { Gardıners } \\
\text { Clay }\end{array}$ & $\begin{array}{c}\text { Jameco } \\
\text { Gravel }\end{array}$ & $\begin{array}{c}\text { Magothy } \\
\text { aquifer }\end{array}$ & $\begin{array}{c}\text { Rarıtan } \\
\text { confınıng unit } \\
\end{array}$ & $\begin{array}{c}\text { Lloyd } \\
\text { aquifer }\end{array}$ & Bedrock & & \\
\hline $\mathrm{K}$ & 687 & 404212 & 735739 & 43 & -157 & & & & & & -142 & & \\
\hline $\mathrm{K}$ & 688 & 404315 & 735757 & 0 & -111 & & & & & & -107 & & \\
\hline $\mathrm{K}$ & 689 & 404333 & 735608 & 31 & -129 & & & & -44 & & -109 & & ' \\
\hline $\mathrm{K}$ & 690 & 404307 & 735651 & 10 & -184 & & & & & & -163 & & \\
\hline K & 691 & 404258 & 735700 & 18 & -177 & & & & & & -149 & & \\
\hline $\mathrm{K}$ & 692 & 404407 & 735644 & 3 & -85 & & & & & & -82 & & \\
\hline $\mathrm{K}$ & 694 & 404105 & 735918 & 16 & -101 & & & & & & -88 & K725 & \\
\hline $\mathrm{K}$ & 698 & 403937 & 740040 & 0 & -100 & -73 & & & & & & & \\
\hline K & 699 & 403753 & 740130 & 75 & -66 & -62 & & & & & & & \\
\hline K & 700 & 404031 & 740015 & 6 & -110 & -51 & -99 & & & & -110 & & \\
\hline $\mathrm{K}$ & 701 & 404006 & 740027 & 0 & -83 & -50 & & & & & & & \\
\hline $\mathrm{K}$ & 702 & 404058 & 735936 & 28 & -112 & & & & & & -88 & & \\
\hline $\mathrm{K}$ & 703 & 404041 & 740014 & 16 & -122 & -93 & -104 & & & & -125 & & \\
\hline K & 704 & 404035 & 740030 & 7 & -123 & -51 & -121 & & & & & & \\
\hline $\mathrm{K}$ & 705 & 404044 & 740100 & 10 & -141 & & & & & & -110 & & \\
\hline $\mathrm{K}$ & 708 & 404132 & 740008 & 6 & -114 & & & & & & -82 & & \\
\hline $\mathrm{K}$ & 709 & 404156 & 735909 & 56 & -83 & & & & & & -62 & & \\
\hline K & 710 & 404401 & 735719 & 13 & -41 & & & & & & -28 & & \\
\hline $\mathrm{K}$ & 711 & 404359 & 735628 & 0 & -74 & & & & & & -74 & & \\
\hline $\mathrm{k}$ & 715 & 404233 & 735644 & 36 & -84 & -49 & & & & & & & \\
\hline $\mathrm{K}$ & 717 & 404223 & 735716 & 45 & -157 & & & & & & -141 & & \\
\hline K & 718 & 403721 & 740121 & 80 & -355 & NR & & & $\mathrm{NR}$ & & -294 & & $\begin{array}{llll}\text { NR } & 80 & \text { TO } & -293\end{array}$ \\
\hline K & 720 & 404029 & 740006 & 13 & -90 & -55 & & & & & & K1091 & \\
\hline $\mathrm{K}$ & 723 & 404202 & 735914 & 57 & -84 & & & & & & -72 & & \\
\hline K & 724 & 404239 & 735633 & 48 & -89 & & & & & & & $\mathrm{~K} 1283$ & \\
\hline $\mathrm{K}$ & 725 & 404104 & 735922 & 14 & -101 & & & & & & -80 & & \\
\hline K & 728 & 404147 & 735906 & 36 & -96 & & & & & & -79 & & \\
\hline $\mathrm{K}$ & 729 & 404141 & 735826 & 45 & -130 & & & & & & -108 & & \\
\hline k & 730 & 404136 & 735902 & 36 & -98 & & & & & & -68 & & \\
\hline$k$ & 731 & 404107 & 735914 & 23 & -187 & & & & & & -160 & & \\
\hline$k$ & 887 & 404201 & 735556 & 49 & -76 & -46 & & & & & & K1031 & \\
\hline $\mathrm{k}$ & 893 & 404225 & 735607 & 20 & -98 & -61 & & & & & & K1130 & \\
\hline K & 894 & 404215 & 735555 & 30 & -252 & -57 & & & -148 & & & & \\
\hline $\mathrm{K}$ & 898 & 404248 & 735709 & -3 & -71 & & & & & & & & \\
\hline K & 910 & 404010 & 735444 & 45 & -137 & -126 & & & & & & & \\
\hline
\end{tabular}


Table 9 Hydrogeologıc units penetrated by wells and test holes in Kıngs, Queens, Nassau, Bronx, New York, and Rıchmond Countıes, New York-Contınued

[Well locatıons are shown on plate 1, PRES, unit present but surface altitude not discermble, NR, no record—no record near altitudes indicated under remarks, Veatch, well number from numbernng system employed in Veatch and others, 1906, BWS, New York City Bureau of Water Supply Well, 20ft, "20 foot" clay may be present]

\begin{tabular}{|c|c|c|c|c|c|c|c|c|c|c|c|c|c|}
\hline \multirow{2}{*}{\multicolumn{2}{|c|}{$\begin{array}{c}\text { Well } \\
\text { Identıfication } \\
\text { number }\end{array}$}} & \multirow[b]{2}{*}{ Latitude } & \multirow[b]{2}{*}{ Longitude } & \multicolumn{2}{|c|}{$\begin{array}{l}\text { Altitude of well, } \\
\text { in feet above or } \\
\text { below sea level }\end{array}$} & \multicolumn{6}{|c|}{$\begin{array}{l}\text { Hydrogeologic unit penetrated and altitude of } \\
\text { unit surface, in feet above or below sea level }\end{array}$} & \multirow[b]{2}{*}{$\begin{array}{l}\text { Located } \\
\text { near well }\end{array}$} & \multirow[b]{2}{*}{ Remarks } \\
\hline & & & & $\begin{array}{l}\text { belov } \\
\text { Top }\end{array}$ & $\frac{\text { sea level }}{\text { Bottom }}$ & $\begin{array}{c}\text { Gardiners } \\
\text { Clay }\end{array}$ & $\begin{array}{c}\text { Jameco } \\
\text { Gravel }\end{array}$ & $\begin{array}{l}\text { Magothy } \\
\text { aquifer }\end{array}$ & $\begin{array}{c}\text { Raritan } \\
\text { confinıng unit }\end{array}$ & $\begin{array}{c}\text { Lloyd } \\
\text { aquifer }\end{array}$ & Bedrock & & \\
\hline K & 916 & 404019 & 735921 & 13 & -149 & -118 & & & & & & K920 & \\
\hline $\mathrm{K}$ & 917 & 404028 & 735906 & 10 & -96 & & & & & & & & \\
\hline $\mathrm{K}$ & 920 & 404020 & 735922 & 13 & -151 & -117 & -122 & & & & & & \\
\hline $\mathrm{K}$ & 921 & 404038 & 735741 & 118 & -213 & NR & NR & & & & -213 & & NR 118 TO -212 \\
\hline $\mathrm{K}$ & 922 & 403919 & 740027 & 12 & -138 & -87 & -102 & & & & & & \\
\hline $\mathrm{K}$ & 930 & 404037 & 735904 & 20 & -160 & -123 & -129 & & & & -160 & K1030 & \\
\hline $\mathrm{K}$ & 944 & 403912 & 740052 & 18 & -139 & -84 & -102 & & & & & K2070 & \\
\hline $\mathrm{K}$ & 952 & 404146 & 735602 & 67 & -55 & -55 & & & & & & & \\
\hline $\mathrm{K}$ & 955 & 404225 & 735610 & 18 & -54 & -47 & & & & & & K1130 & \\
\hline K & 956 & 404037 & 735905 & 22 & -160 & -96 & -130 & & & & -160 & K1030 & \\
\hline $\mathrm{K}$ & 1010 & 404009 & 735941 & 20 & -161 & PRES & -136 & & & & & & \\
\hline $\mathrm{K}$ & 1012 & 403912 & 740052 & 16 & -159 & -100 & -124 & & & & & K2070 & \\
\hline $\mathrm{K}$ & 1015 & 404146 & 735807 & 20 & -72 & -72 & & & & & & K1548 & \\
\hline $\mathrm{K}$ & 1018 & 404146 & 735807 & 18 & -98 & -44 & & & & & & K1548 & \\
\hline K & 1020 & 403420 & 735942 & 5 & -108 & & & & & & & & \\
\hline $\mathrm{K}$ & 1021 & 403428 & 735859 & 10 & -110 & & & & & & & & \\
\hline $\mathrm{K}$ & 1030 & 404037 & 735905 & 20 & -162 & -123 & -132 & & & & -162 & & \\
\hline $\mathrm{K}$ & 1031 & 404204 & 735554 & 49 & -56 & -56 & & & & & & & \\
\hline $\mathrm{K}$ & 1051 & 404150 & 735803 & 20 & -66 & -60 & & & & & & & \\
\hline $\mathrm{K}$ & 1054 & 404029 & 735230 & 26 & -64 & -63 & & & & & & & \\
\hline $\mathrm{K}$ & 1056 & 403452 & 735248 & 7 & -733 & & -123 & -213 & -493 & -683 & & & Veatch 130 \\
\hline $\mathrm{K}$ & 1057 & 403503 & 735251 & 13 & -711 & & -127 & -217 & -487 & -693 & & & Veatch 131 \\
\hline $\mathrm{K}$ & 1073 & 404117 & 735848 & 32 & -88 & & & & & & -62 & & \\
\hline $\mathrm{K}$ & 1091 & 404030 & 740007 & 11 & -113 & -38 & -88 & & & & & & \\
\hline K & 1112 & 404314 & 735723 & 7 & -48 & & & & & & & & \\
\hline $\mathrm{K}$ & 1130 & 404225 & 735613 & 18 & -71 & -63 & & & & & & & 1 \\
\hline $\mathrm{K}$ & 1148 & 403916 & 740036 & 11 & -139 & -86 & -95 & & & & & & \\
\hline $\mathrm{K}$ & 1153 & 404206 & 735605 & 40 & -61 & -61 & & & & & & K2136 & \\
\hline K & 1160 & 404201 & 735656 & 10 & -125 & -69 & -101 & & & & & K3133 & \\
\hline K & 1190 & 404056 & 740025 & 10 & -55 & -54 & & & & & & K1191 & \\
\hline $\mathrm{K}$ & 1191 & 404055 & 740026 & 1 & -59 & -59 & & & & & & & \\
\hline $\mathrm{K}$ & 1192 & 404055 & 740011 & 30 & -82 & & & & & & & & \\
\hline $\mathrm{K}$ & 1271 & 403920 & 740048 & 5 & $-1,498$ & -90 & -134 & & & & -207 & & Veatch 5 \\
\hline $\mathrm{K}$ & 1273 & 404206 & 735605 & 40 & -235 & -65 & & & PRES & & & K2136 & Veatch 35 \\
\hline $\mathrm{K}$ & 1274 & 404202 & 735655 & 10 & -155 & -55 & -140 & & & & & K3133 & Veatch 37 \\
\hline
\end{tabular}


N Table 9. Hydrogeologic units penetrated by wells and test holes in Kıngs, Queens, Nassau, Bronx, New York, and Richmond Countıes, New York-Contınued

[Well locations are shown on plate 1, PRES, unit present but surface altitude not discernible, NR, no record-no record near altitudes indicated under remarks, Veatch, well number from numbering system employed in Veatch and others, 1906, BWS, New York City Bureau of Water Supply Well, 20ft, "20 foot" clay may be present]

\begin{tabular}{|c|c|c|c|c|c|c|c|c|c|c|c|c|}
\hline \multirow{3}{*}{$\begin{array}{c}\text { Well } \\
\begin{array}{c}\text { Identification } \\
\text { number }\end{array} \\
\end{array}$} & \multirow[b]{3}{*}{ Latitude } & \multirow[b]{3}{*}{ Longitude } & \multirow{2}{*}{\multicolumn{2}{|c|}{$\begin{array}{l}\text { Altitude of well, } \\
\text { in feet above or } \\
\text { below sea level }\end{array}$}} & \multirow{3}{*}{$\begin{array}{c}\begin{array}{c}\text { Gardıners } \\
\text { Clay }\end{array} \\
\end{array}$} & \multicolumn{4}{|c|}{$\begin{array}{l}\text { Hydrogeologic unit penetrated and altitude of } \\
\text { unit surface, in feet above or below sea level }\end{array}$} & \multirow[b]{3}{*}{ Bedrock } & \multirow{3}{*}{$\begin{array}{l}\text { Located } \\
\text { near well }\end{array}$} & \multirow[b]{3}{*}{ Remarks } \\
\hline & & & & & & Jameco & Magothy & Rarıtan & Lloyd & & & \\
\hline & & & Top & Bottom & & Gravel & aquifer & confınıng unit & aquifer & & & \\
\hline K 1275 & 404202 & 735655 & 10 & -165 & PRES & -129 & & & & & K3133 & Veatch 38 \\
\hline K 1283 & 404239 & 735632 & 45 & -195 & & & & PRES & & & & Veatch 62 \\
\hline K 1286 & 404012 & 735229 & 10 & -154 & -60 & -108 & & & & & & Veatch 135 \\
\hline K 1287 & 403903 & 735734 & 50 & -111 & & & & & & & K1641 & \\
\hline K 1288 & 404143 & 735809 & 30 & -78 & -78 & & & & & & K1548 & \\
\hline K 1303 & 404256 & 735734 & 16 & -74 & -40 & & & & & & K2262 & \\
\hline K 1305 & 404200 & 735701 & 10 & -156 & -82 & -112 & & & & & $\mathrm{~K} 3133$ & \\
\hline K 1309 & 403940 & 735458 & 30 & -201 & -124 & -133 & & & & & & \\
\hline K 1313 & 404146 & 735756 & 31 & -130 & -72 & & & & & -129 & $\mathrm{~K} 1340$ & \\
\hline K 1319 & 404145 & 735757 & 31 & -114 & -72 & & & & & & $\mathrm{~K} 1340$ & \\
\hline K 1322 & 403423 & 735954 & 5 & -180 & -119 & -150 & -180 & & & & & \\
\hline K 1332 & 404022 & 735937 & 10 & -158 & -121 & -158 & & & & & & \\
\hline K 1336 & 404204 & 735602 & 50 & -113 & -52 & & & & & & K2136 & \\
\hline K 1339 & 403941 & 735541 & 40 & -129 & -119 & & & & & & & \\
\hline K 1340 & 404145 & 735757 & 25 & -120 & -82 & & & & & -120 & & \\
\hline K 1343 & 403934 & 735539 & 39 & -129 & -123 & & & & & & $\mathrm{~K} 1346$ & \\
\hline K 1344 & 404200 & 735701 & 10 & -161 & -85 & -101 & & & & & K3133 & \\
\hline K 1346 & 404232 & 735532 & 39 & -129 & -123 & & & & & & & \\
\hline K 1354 & 403911 & 735832 & 70 & -110 & -95 & & & & & & & \\
\hline K 1355 & 403905 & 735628 & 46 & -129 & -74 & & & & & & K1360 & \\
\hline K 1359 & 403908 & 735526 & 28 & -177 & -112 & & & & & & & \\
\hline K 1360 & 403904 & 735628 & 45 & -90 & -70 & & & & & & & \\
\hline K 1363 & 403923 & 735527 & 33 & -137 & -131 & & & & & & & \\
\hline K 1370 & 404338 & 735555 & 27 & -50 & & & & -48 & & & & \\
\hline K 1488 & 404147 & 735805 & 25 & -83 & -75 & & & & & & $\mathrm{~K} 1548$ & \\
\hline K 1490 & 404229 & 735623 & 35 & -100 & -70 & & & & & & & \\
\hline K 1494 & 403841 & 740051 & 80 & -164 & -162 & & & & & & & \\
\hline K 1504 & 403928 & 735738 & 64 & -116 & -114 & & & & & & & \\
\hline K 1508 & 403912 & 735545 & 28 & -118 & -103 & & & & & & & \\
\hline K 1510 & 404003 & 735517 & 52 & -153 & -113 & & & & & & & \\
\hline K 1536 & 404033 & 735950 & 14 & -142 & -109 & -122 & & & & & & \\
\hline K 1548 & 404145 & 735804 & 38 & -78 & -78 & & & & & & & \\
\hline K 1558 & 403420 & 735925 & 5 & -113 & & & & & & & & \\
\hline K 1560 & 404334 & 735552 & 30 & -71 & & & & -71 & & & & \\
\hline K 1561 & 404111 & 740020 & 5 & -55 & -55 & & & & & & & \\
\hline
\end{tabular}


Table 9. Hydrogeologic units penetrated by wells and test holes in Kıngs, Queens, Nassau, Bronx, New York, and Richmond Countıes, New York-Contınued [Well locations are shown on plate 1, PRES, unit present but surface altitude not discernible, NR, no record-no record near altitudes indıcated under remarks, Veatch, well number from numbering system employed in Veatch and others, 1906, BWS, New York City Bureau of Water Supply Well, 20ft, "20 foot" clay may be present]

\begin{tabular}{|c|c|c|c|c|c|c|c|c|c|c|c|c|}
\hline \multirow{2}{*}{$\begin{array}{c}\text { Welī } \\
\text { Identıfication } \\
\text { number }\end{array}$} & \multirow[b]{2}{*}{ Latitude } & \multirow[b]{2}{*}{ Longitude } & \multicolumn{2}{|c|}{$\begin{array}{l}\text { Altitude of well, } \\
\text { in feet above or } \\
\text { below sea level }\end{array}$} & \multicolumn{6}{|c|}{$\begin{array}{l}\text { Hydrogeologic unit penetrated and altitude of } \\
\text { unit surface, in feet above or below sea level }\end{array}$} & \multirow[b]{2}{*}{$\begin{array}{l}\text { Located } \\
\text { near well }\end{array}$} & \multirow[b]{2}{*}{ Remarks } \\
\hline & & & $\begin{array}{l}\text { belov } \\
\text { Top }\end{array}$ & $\frac{\text { a level }}{\text { Bottom }}$ & $\begin{array}{c}\text { Gardiners } \\
\text { Clay }\end{array}$ & $\begin{array}{c}\text { Jameco } \\
\text { Gravel }\end{array}$ & $\begin{array}{c}\text { Magothy } \\
\text { aquifer }\end{array}$ & $\begin{array}{c}\text { Rarıtan } \\
\text { confinıng unit }\end{array}$ & $\begin{array}{l}\text { Lloyd } \\
\text { aquifer }\end{array}$ & Bedrock & & \\
\hline K 1575 & 404211 & 735534 & 30 & -55 & -55 & & & & & & & \\
\hline K 1578 & 404058 & 735808 & 74 & -129 & -129 & & & & & & & \\
\hline K 1600 & 404202 & 735657 & 10 & -147 & -70 & -101 & & & & & K3133 & \\
\hline K 1629 & 404201 & 735656 & 10 & -160 & -60 & -90 & & & & & K3133 & \\
\hline K 1641 & 403900 & 735728 & 50 & -154 & & & & & & & & \\
\hline K 1662 & 404205 & 735740 & 6 & -141 & PRES & & & & & -122 & & \\
\hline K 1713 & 404046 & 735644 & 50 & -132 & -128 & & & & & & & \\
\hline K 1857 & 404014 & 735533 & 100 & -118 & -108 & & & & & & & \\
\hline K 1900 & 404028 & 740049 & 10 & -125 & -119 & & & & & & & \\
\hline K 1932 & 403831 & 735611 & 26 & -125 & & & & & & & & \\
\hline K 1977 & 404308 & 735547 & 15 & -148 & & & & -95 & & & & \\
\hline K 1990 & 404234 & 735536 & 15 & -55 & & & & & & & & \\
\hline K 2044 & 404135 & 735919 & 48 & -92 & & & & & & -92 & & \\
\hline K 2056 & 404120 & 740006 & 10 & -75 & -52 & -61 & & & & & & \\
\hline K 2059 & 403709 & 735923 & 38 & -184 & -139 & -158 & & & & & & \\
\hline K 2069 & 404202 & 735710 & 10 & -167 & -75 & -123 & & & & -165 & & \\
\hline K 2070 & 403913 & 740053 & 18 & -151 & PRES & PRES & & & & & & \\
\hline K 2136 & 404204 & 735610 & 50 & -62 & -55 & & & & & & & \\
\hline K 2172 & 404144 & 735919 & 50 & -66 & & & & & & & & \\
\hline K 2173 & 404215 & 735816 & 5 & -110 & & & & & & -110 & & \\
\hline K 2204 & 403634 & 735729 & 19 & -171 & -148 & -154 & & & & & & \\
\hline K 2227 & 404413 & 735726 & 10 & -40 & & & & & & -40 & & \\
\hline K 2262 & 404257 & 735737 & 8 & -53 & -53 & & & & & & & \\
\hline K 2286 & 404158 & 735653 & 15 & -175 & -68 & -98 & & & & & K3133 & \\
\hline K 2326 & 403630 & 735519 & 15 & -185 & -181 & & & & & & & \\
\hline K 2342 & 403641 & 735510 & 5 & -149 & -149 & & & & & & & \\
\hline K 2434 & 404200 & 735659 & 10 & -186 & -72 & -102 & & & & & K3133 & \\
\hline K 2450 & 404033 & 735730 & 10 & -91 & & & & & & & & \\
\hline K 2488 & 403421 & 735826 & 10 & -214 & -148 & -176 & & & & & & \\
\hline K 2512 & 404009 & 735953 & 10 & -142 & -120 & -129 & & & & & K2513 & \\
\hline K 2513 & 404009 & 735953 & 10 & -120 & -109 & & & & & & & \\
\hline K 2533 & 404228 & 735639 & 30 & -62 & -49 & & & & & & & \\
\hline K 2556 & 404047 & 735716 & 65 & -100 & & & & & & & & \\
\hline K 2568 & 404223 & 735527 & 20 & -80 & -77 & & & & & & & \\
\hline K 2582 & 403732 & 735737 & 10 & -186 & & -140 & & & & & & \\
\hline
\end{tabular}


\$ Table 9 Hydrogeologıc units penetrated by wells and test holes in Kıngs, Queens, Nassau, Bronx, New York, and Rıchmond Countıes, New York-Contınued

[Well locations are shown on plate 1, PRES, unit present but surface altıtude not discernible, NR, no record-no record near altitudes indicated under remarks, Veatch, well number from numberıng system employed in Veatch and others, 1906, BWS, New York City Bureau of Water Supply Well, $20 \mathrm{ft}$, "20 foot" clay may be present]

\begin{tabular}{|c|c|c|c|c|c|c|c|c|c|c|c|c|c|}
\hline \multirow{2}{*}{\multicolumn{2}{|c|}{$\begin{array}{c}\text { Well } \\
\text { Identification } \\
\text { number }\end{array}$}} & \multirow[b]{2}{*}{ Latitude } & \multirow[b]{2}{*}{ Longitude } & \multicolumn{2}{|c|}{$\begin{array}{l}\text { Altitude of well, } \\
\text { in feet above or } \\
\text { below sea level }\end{array}$} & \multicolumn{6}{|c|}{$\begin{array}{l}\text { Hydrogeologic unit penetrated and altitude of } \\
\text { unit surface, in feet above or below sea level }\end{array}$} & \multirow[b]{2}{*}{$\begin{array}{l}\text { Located } \\
\text { near well }\end{array}$} & \multirow[b]{2}{*}{ Remarks } \\
\hline & & & & $\frac{\text { belov }}{\text { Top }}$ & $\frac{\text { sea level }}{\text { Bottom }}$ & $\begin{array}{c}\text { Gardıners } \\
\text { Clay }\end{array}$ & $\begin{array}{c}\text { Jameco } \\
\text { Gravel }\end{array}$ & $\begin{array}{l}\text { Magothy } \\
\text { aquifer }\end{array}$ & $\begin{array}{c}\text { Raritan } \\
\text { confınıng unit }\end{array}$ & $\begin{array}{l}\text { Lloyd } \\
\text { aquifer }\end{array}$ & Bedrock & & \\
\hline & 2859 & 403451 & 735856 & 10 & -490 & -160 & -198 & -292 & -360 & -458 & & & \\
\hline & 2860 & 403822 & 735255 & 10 & -206 & -163 & -183 & & & & & & \\
\hline K & 3129 & 403748 & 735721 & 30 & -240 & PRES & -204 & & & & & K3132 & \\
\hline $\mathrm{K}$ & 3130 & 403748 & 735719 & 30 & -258 & -172 & -206 & & & & & K3132 & \\
\hline K & 3131 & 403749 & 735716 & 30 & -261 & -160 & -200 & & & & & K3132 & \\
\hline $\mathrm{K}$ & 3132 & 403750 & 735717 & 30 & -280 & -180 & -215 & & & & & & \\
\hline K & 3133 & 404158 & 735658 & 15 & -188 & -83 & -107 & & & & 0 & & \\
\hline K & 3151 & 403921 & 735450 & 29 & -232 & -66 & -103 & -170 & -220 & & & K3184 & \\
\hline K & 3176 & 403920 & 735446 & 29 & -146 & -47 & -136 & & & & & K3184 & \\
\hline $\mathrm{K}$ & 3177 & 403921 & 735447 & 29 & -146 & -46 & -131 & & & & & K3184 & \\
\hline $\mathrm{K}$ & 3178 & 403922 & 735448 & 29 & -146 & -43 & -131 & & & & & K3184 & \\
\hline & 3179 & 403923 & 735448 & 29 & -146 & -43 & -136 & & & & & K3184 & \\
\hline $\mathrm{K}$ & 3180 & 403921 & 735446 & 29 & -173 & -56 & -133 & -143 & & & & K3184 & \\
\hline K & 3181 & 403922 & 735446 & 29 & -146 & -54 & -133 & & & & & K3184 & \\
\hline K & 3182 & 403923 & 735447 & 29 & -146 & -57 & -138 & & & & & K3184 & \\
\hline & 3183 & 403925 & 735449 & 29 & -173 & -56 & -133 & -143 & & & & K3184 & \\
\hline K & 3184 & 403924 & 735447 & 29 & -174 & -42 & -134 & -142 & & & & & \\
\hline 0 & 13 & 404506 & 735554 & 24 & -65 & & & & & & -65 & & \\
\hline$Q$ & 17 & 404427 & 735656 & 17 & -158 & & & & & & -11 & & \\
\hline Q & 27 & 404435 & 735221 & 57 & -244 & & & -10 & -60 & -190 & -244 & & \\
\hline$Q$ & 29 & 404229 & 735202 & 80 & -145 & & & -96 & & & & & \\
\hline 0 & 31 & 404224 & 735133 & 70 & -421 & -84 & & -120 & -200 & -360 & -421 & & \\
\hline$\hat{Q}$ & 33 & 404701 & 735049 & 27 & -183 & & & & -66 & -126 & -179 & Q455 & \\
\hline $\mathrm{Q}$ & 37 & 404401 & 734659 & 72 & -71 & & & -28 & & & & & \\
\hline $\mathrm{Q}$ & 52 & 404207 & 735341 & 80 & -70 & -70 & & & & & & & \\
\hline $\mathrm{Q}$ & 62 & 404502 & 735510 & 38 & -91 & & & & & & -91 & & \\
\hline$\hat{Q}$ & 64 & 404429 & 735257 & 35 & & & & & -80 & & & Q268 & \\
\hline $\mathrm{Q}$ & 65 & 404500 & 735106 & 20 & -264 & & & & -69 & -190 & -241 & & \\
\hline Q & 95 & 404526 & 735611 & 20 & -72 & & & & & & -70 & & \\
\hline Q & 111 & 403635 & 734539 & 9 & $-1,005$ & & & -160 & -597 & -808 & & Q1932 & \\
\hline Q & 122 & 404428 & 735557 & 42 & -83 & & & & & & & & \\
\hline Q & 123 & 403503 & 734952 & 8 & -952 & -197 & -242 & -348 & -455 & -751 & & & \\
\hline Q & 127 & 404539 & 734954 & 40 & -160 & & & & -50 & & & 01516 & \\
\hline Q & 161 & 404507 & 735711 & 5 & -145 & & & & & & -9 & & \\
\hline $\mathrm{Q}$ & 165 & 404529 & 735649 & 5 & -200 & & & & & & 0 & & \\
\hline
\end{tabular}


Table 9 Hydrogeologic units penetrated by wells and test holes in Kıngs, Queens, Nassau, Bronx, New York, and Richmond Counties, New York-Contınued

[Well locations are shown on plate 1, PRES, untt present but surface alttude not discernble, NR, no record-no record near altutudes indicated under remarks, Veatch, well number from numbernng system employed in Veatch and others, 1906, BWS, New York City Bureau of Water Supply Well, $20 \mathrm{ft}$, " 20 foot" clay may be present]

\begin{tabular}{|c|c|c|c|c|c|c|c|c|c|c|c|c|c|}
\hline \multirow{3}{*}{\multicolumn{2}{|c|}{$\begin{array}{c}\text { Well } \\
\text { identification } \\
\text { number }\end{array}$}} & \multirow[b]{3}{*}{ Latitude } & \multirow[b]{3}{*}{ Longitude } & \multirow{2}{*}{\multicolumn{2}{|c|}{$\begin{array}{l}\text { Altitude of well, } \\
\text { in feet above or } \\
\text { below sea level }\end{array}$}} & \multicolumn{6}{|c|}{$\begin{array}{l}\text { Hydrogeologic unit penetrated and altitude of } \\
\text { unit surface, in feet above or below sea level }\end{array}$} & \multirow{3}{*}{$\begin{array}{c}\text { Located } \\
\text { near well }\end{array}$} & \multirow[b]{3}{*}{ Remarks } \\
\hline & & & & & & \multirow{2}{*}{$\begin{array}{c}\begin{array}{c}\text { Gardıners } \\
\text { Clay }\end{array} \\
\end{array}$} & \multirow{2}{*}{$\begin{array}{c}\text { Jameco } \\
\text { Gravel }\end{array}$} & \multirow{2}{*}{$\begin{array}{c}\text { Magothy } \\
\text { aquifer }\end{array}$} & \multirow{2}{*}{$\begin{array}{c}\text { Rarıtan } \\
\text { confınıng unit } \\
\end{array}$} & \multirow{2}{*}{$\begin{array}{l}\text { Lloyd } \\
\text { aquifer }\end{array}$} & \multirow[b]{2}{*}{ Bedrock } & & \\
\hline & & & & Top & Bottom & & & & & & & & \\
\hline$Q$ & 171 & 404442 & 735618 & 46 & -454 & & & & & & -10 & & \\
\hline Q & 183 & 404646 & 735058 & 5 & -165 & & & & 5 & -131 & & & \\
\hline Q & 184 & 404414 & 735452 & 90 & -492 & & & & -49 & & -114 & & \\
\hline Q & 192 & 404337 & 735331 & 100 & -73 & & & & 0 & & & & \\
\hline Q & 206 & 404443 & 735409 & 47 & -170 & & & & -95 & & -170 & QBWS4 & NR -50 TO $\quad-95$ \\
\hline$Q$ & 224 & 403953 & 734526 & 15 & -473 & -109 & & -199 & -423 & & & Q678 & \\
\hline Q & 237 & 404113 & 735109 & 36 & -541 & & -108 & -177 & -262 & -400 & -520 & & \\
\hline$Q$ & 262 & 404527 & 735403 & 10 & -217 & & & & -28 & & -128 & & Veatch 162 \\
\hline $\mathrm{Q}$ & 263 & 404500 & 735458 & 38 & -87 & & & & -47 & & -80 & & Veatch 99 \\
\hline Q & 268 & 404421 & 735255 & 27 & -270 & & & & NR & & -266 & & NR 27 TO -265 \\
\hline Q & 272 & 404302 & 734934 & 13 & -482 & & & & PRES & -313 & -457 & Q584 & \\
\hline Q & 273 & 404257 & 734937 & 26 & -462 & & & & -131 & -282 & & Q584 & \\
\hline$Q$ & 274 & 404447 & 734759 & 20 & -387 & & & -25 & -148 & -284 & -387 & & \\
\hline$Q$ & 275 & 404543 & 734450 & 5 & -451 & & & -75 & -231 & -355 & & Q276 & \\
\hline$Q$ & 276 & 404511 & 734433 & 25 & -506 & & & -25 & -191 & -371 & -504 & & \\
\hline Q & 278 & 404524 & 734438 & 16 & -520 & & & -59 & -196 & -336 & -498 & Q1057 & \\
\hline $\mathrm{Q}$ & 282 & 404448 & 734743 & 30 & -433 & & & -38 & -133 & -277 & & $\mathrm{Q} 283$ & \\
\hline Q & 283 & 404450 & 734750 & 27 & -420 & & & -41 & -123 & -283 & -383 & & \\
\hline$Q$ & 287 & 403624 & 734916 & 5 & -712 & -150 & -230 & -315 & PRES & -655 & & & \\
\hline $\mathrm{Q}$ & 290 & 403354 & 735326 & 5 & -723 & -195 & -215 & -280 & -485 & -680 & & & \\
\hline Q & 301 & 404214 & 734935 & 67 & -43 & -43 & & & & & & & \\
\hline$Q$ & 306 & 404147 & 734718 & 26 & -71 & -47 & & & & & & Q1839 & \\
\hline$Q$ & 310 & 404141 & 734413 & 47 & -64 & & & -58 & & & & Q2443 & \\
\hline$\tilde{Q}$ & 311 & 404107 & 734805 & 28 & -232 & -100 & -177 & & & & & Q3157 & \\
\hline$Q$ & 312 & 404044 & 734552 & 22 & -254 & -48 & -148 & -242 & & & & & \\
\hline$Q$ & 314 & 404049 & 734752 & 35 & -275 & -81 & -160 & & -275 & & & Q3156 & \\
\hline$Q$ & 317 & 404154 & 734937 & 61 & -539 & -62 & -202 & & -234 & -392 & & Q566 & \\
\hline Q & 318 & 404254 & 734813 & 131 & -119 & & & -79 & & & & Q2137 & \\
\hline$Q$ & 324 & 404155 & 734638 & 32 & -91 & -33 & & & & & & Q571 & \\
\hline Q & 332 & 403943 & 734437 & 8 & -367 & -111 & & -132 & & & & & \\
\hline$Q$ & 333 & 403958 & 734502 & 12 & -128 & -49 & -64 & & & & & Q1197 & \\
\hline$Q$ & 334 & 403952 & 734535 & 8 & -182 & -67 & & -103 & & & & Q1305 & \\
\hline Q & 335 & 404004 & 734620 & 13 & -322 & -70 & -147 & -284 & & & & & \\
\hline$\tilde{Q}$ & 336 & 404016 & 734716 & 10 & -163 & -85 & -135 & & & & & Q1876 & \\
\hline Q & 337 & 404000 & 734742 & 8 & -214 & -106 & -163 & & & & & & \\
\hline
\end{tabular}


ส้ Table 9 Hydrogeologıc units penetrated by wells and test holes in Kıngs, Queens, Nassau, Bronx, New York, and Richmond Counties, New York-Continued

[Well locations are shown on plate 1, PRES, unit present but surface altutude not discernble, NR, no record—no record near alttides indicated under remarks, Veatch, well number from numbernng system employed in Veatch and others, 1906, BWS, New York City Bureau of Water Supply Well, 20ft, "20 foot" clay may be present]

\begin{tabular}{|c|c|c|c|c|c|c|c|c|c|c|c|c|c|}
\hline \multirow{2}{*}{\multicolumn{2}{|c|}{$\begin{array}{c}\text { Well } \\
\text { Identification } \\
\text { number }\end{array}$}} & \multirow[b]{2}{*}{ Latıtude } & \multirow[b]{2}{*}{ Longitude } & \multicolumn{2}{|c|}{$\begin{array}{l}\text { Altitude of well, } \\
\text { in feet above or } \\
\text { below sea level }\end{array}$} & \multicolumn{6}{|c|}{$\begin{array}{l}\text { Hydrogeologic unit penetrated and altitude of } \\
\text { unit surface, in feet above or below sea level }\end{array}$} & \multirow[b]{2}{*}{$\begin{array}{l}\text { Located } \\
\text { near well }\end{array}$} & \multirow[b]{2}{*}{ Remarks } \\
\hline & & & & $\begin{array}{l}\text { belov } \\
\text { Top }\end{array}$ & $\frac{\text { a level }}{\text { Bottom }}$ & $\begin{array}{l}\text { Gardıners } \\
\text { Clay }\end{array}$ & $\begin{array}{l}\text { Jameco } \\
\text { Gravel }\end{array}$ & $\begin{array}{l}\text { Magothy } \\
\text { aquifer }\end{array}$ & $\begin{array}{c}\text { Raritan } \\
\text { confınıng unit } \\
\end{array}$ & $\begin{array}{l}\text { Lloyd } \\
\text { aquifer }\end{array}$ & Bedrock & & \\
\hline $\mathrm{Q}$ & 338 & 403957 & 734805 & 10 & -220 & -91 & -195 & & & & & & \\
\hline$Q$ & 339 & 404002 & 734830 & 10 & -197 & -103 & -174 & & & & & Q1175 & \\
\hline$Q$ & 340 & 404026 & 735135 & 9 & -153 & PRES & -71 & -121 & & & & Q634 & \\
\hline Q & 341 & 404243 & 735134 & 70 & -176 & & & -58 & & & & & \\
\hline$Q$ & 344 & 403959 & 735005 & 10 & -326 & & -110 & -178 & & & & & \\
\hline Q & 345 & 404006 & 735040 & 10 & -209 & & -143 & -189 & & & & & \\
\hline Q & 350 & 404020 & 735007 & 33 & -622 & & -103 & -208 & -265 & -453 & -577 & Q2384 & \\
\hline$Q$ & 364 & 404449 & 735333 & 63 & -126 & & & & -27 & & & Q2148 & \\
\hline$Q$ & 369 & 404438 & 735520 & 80 & -72 & & & & & & -61 & & \\
\hline$Q$ & 374 & 404632 & 735530 & 33 & -31 & & & & & & -17 & & \\
\hline$Q$ & 375 & 404633 & 735558 & 15 & -43 & & & & & & -41 & & \\
\hline$Q$ & 376 & 404518 & 735521 & 43 & -79 & & & & & & -59 & & \\
\hline$Q$ & 377 & 404539 & 735503 & 64 & -23 & & & & & & -3 & & \\
\hline$Q$ & 378 & 404549 & 735455 & 75 & -28 & & & & & & -8 & & \\
\hline Q & 379 & 404529 & 735512 & 52 & -95 & & & & & & -74 & & \\
\hline Q & 380 & 404559 & 735447 & 78 & -30 & & & & & & -10 & & \\
\hline$Q$ & 381 & 404647 & 735354 & 19 & -76 & & & & & & -56 & & \\
\hline$Q$ & 382 & 404617 & 735429 & 58 & -69 & & & & & & -51 & & \\
\hline$Q$ & 386 & 404451 & 735534 & 75 & -147 & & & & & & -73 & Q602 & \\
\hline$Q$ & 387 & 404425 & 735539 & 64 & -112 & & & & & & -88 & & \\
\hline $\mathrm{Q}$ & 388 & 404433 & 735536 & 70 & -133 & & & & & & -106 & & \\
\hline$Q$ & 389 & 404508 & 735529 & 35 & -49 & & & & & & -28 & & \\
\hline$\hat{Q}$ & 390 & 404351 & 735605 & 23 & -188 & & & & -56 & & -171 & & \\
\hline$Q$ & 391 & 404357 & 735557 & 62 & -135 & & & & & & -115 & & \\
\hline$Q$ & 392 & 404403 & 735549 & 65 & -101 & & & & & & -85 & & \\
\hline$Q$ & 393 & 404345 & 735557 & 17 & -153 & & & & -59 & & -133 & & \\
\hline$\tilde{Q}$ & 394 & 404411 & 735542 & 48 & -127 & & & & -42 & & -107 & & \\
\hline Q & 395 & 404422 & 735704 & 7 & -67 & & & & & & -67 & & \\
\hline$Q$ & 398 & 404437 & 735642 & 2 & -65 & & & & & & & & \\
\hline Q & 399 & 404447 & 735653 & 13 & -55 & & & & & & & & \\
\hline Q & 403 & 403352 & 735440 & 5 & -865 & -192 & -206 & -237 & -486 & -643 & -865 & & \\
\hline$Q$ & 404 & 404652 & 735517 & 43 & -3 & & & & & & 8 & & \\
\hline Q & 405 & 404702 & 735347 & 0 & -95 & & & & & & -69 & & \\
\hline$Q$ & 406 & 404646 & 735514 & 53 & -29 & & & & & & -24 & & \\
\hline $\mathrm{Q}$ & 407 & 404623 & 735521 & 22 & -28 & & & & & & -23 & & \\
\hline
\end{tabular}


Table 9. Hydrogeologic units penetrated by wells and test holes in Kıngs, Queens, Nassau, Bronx, New York, and Rıchmond Countıes, New York-Contınued [Well locations are shown on plate 1, PRES, unit present but surface altitude not discernible, NR, no record—no record near altitudes indicated under remarks, Veatch, well number from numbering system employed in Veatch and others, 1906, BWS, New York City Bureau of Water Supply Well, 20ft, "20 foot" clay may be present]

\begin{tabular}{|c|c|c|c|c|c|c|c|c|c|c|c|c|c|}
\hline \multirow{3}{*}{\multicolumn{2}{|c|}{$\begin{array}{c}\text { Well } \\
\text { Identification } \\
\text { number }\end{array}$}} & \multirow[b]{3}{*}{ Latıtude } & \multirow[b]{3}{*}{ Longitude } & \multirow{2}{*}{\multicolumn{2}{|c|}{$\begin{array}{l}\text { Altitude of well, } \\
\text { in feet above or } \\
\text { below sea level }\end{array}$}} & \multicolumn{6}{|c|}{$\begin{array}{l}\text { Hydrogeologic unit penetrated and altitude of } \\
\text { unit surface, in feet above or below sea level }\end{array}$} & \multirow{3}{*}{$\begin{array}{l}\text { Located } \\
\text { near well }\end{array}$} & \multirow[b]{3}{*}{ Remarks } \\
\hline & & & & & & \multirow{2}{*}{$\begin{array}{c}\text { Gardiners } \\
\text { Clay }\end{array}$} & \multirow{2}{*}{$\begin{array}{l}\text { Jameco } \\
\text { Gravel }\end{array}$} & \multirow{2}{*}{$\begin{array}{c}\text { Magothy } \\
\text { aquifer }\end{array}$} & \multirow{2}{*}{$\begin{array}{c}\text { Raritan } \\
\text { confınıng unıt } \\
\end{array}$} & \multirow{2}{*}{$\begin{array}{c}\text { Lloyd } \\
\text { aquifer }\end{array}$} & \multirow[b]{2}{*}{ Bedrock } & & \\
\hline & & & & Top & Bottom & & & & & & & & \\
\hline$Q$ & 408 & 404610 & 735608 & 6 & -51 & & & & & & -42 & & \\
\hline$Q$ & 411 & 404609 & 735435 & 64 & -61 & & & & & & -41 & & \\
\hline Q & 412 & 404549 & 735424 & 66 & -62 & & & & & & -42 & & \\
\hline$Q$ & 413 & 404612 & 735510 & 56 & -55 & & & & & & -38 & & \\
\hline Q & 414 & 404618 & 735352 & 21 & -102 & & & & & & -71 & & \\
\hline$Q$ & 415 & 404629 & 735342 & 8 & -102 & & & & & & -82 & & \\
\hline$Q$ & 416 & 404646 & 735325 & 0 & -143 & & & & & & -89 & & \\
\hline $\mathrm{Q}$ & 417 & 404522 & 735447 & 46 & -75 & & & & & & -54 & & \\
\hline$Q$ & 422 & 404430 & 735728 & 7 & -59 & & & & & & -49 & & \\
\hline$Q$ & 423 & 404435 & 735706 & 17 & -52 & & & & & & -42 & & \\
\hline Q & 425 & 404444 & 735535 & 75 & -84 & & & & & & -64 & Q453 & \\
\hline$Q$ & 426 & 404446 & 435500 & 63 & -84 & & & & -32 & & -64 & & \\
\hline$Q$ & 427 & 404436 & 735502 & 91 & -136 & & & & -37 & & -121 & & \\
\hline$Q$ & 428 & 404415 & 735507 & 98 & -169 & & & & -86 & & -149 & & \\
\hline$Q$ & 429 & 404407 & 735529 & 64 & -170 & & & & -31 & & -150 & & \\
\hline Q & 431 & 404409 & 735503 & 104 & -139 & & & & -71 & & -118 & & \\
\hline$Q$ & 432 & 404401 & 735509 & 115 & -187 & & & & -68 & & -167 & & \\
\hline$Q$ & 434 & 404353 & 735508 & 89 & -174 & & & & -30 & & -147 & & \\
\hline$Q$ & 435 & 404346 & 735511 & 63 & -196 & & & & -78 & & -176 & & \\
\hline$Q$ & 436 & 404313 & 735526 & 8 & -209 & -57 & & & -155 & & -187 & & \\
\hline Q & 437 & 404320 & 735501 & 5 & -255 & -97 & & & -131 & & -207 & Q1274 & \\
\hline$Q$ & 438 & 404325 & 735514 & 4 & -204 & -95 & & & -113 & & -184 & & \\
\hline$Q$ & 439 & 404513 & 735056 & 10 & -118 & & & & & & & & \\
\hline$Q$ & 440 & 404446 & 735041 & 27 & -94 & & & & & & & Q1028 & \\
\hline$\hat{Q}$ & 441 & 404500 & 735023 & 2 & -83 & & & & & & & Q2420 & \\
\hline$Q$ & 442 & 404459 & 734959 & 10 & -84 & & & & & & & & \\
\hline Q & 443 & 404439 & 735049 & 27 & -76 & & & & & & & & \\
\hline$Q$ & 444 & 404435 & 735036 & 2 & -80 & & & & & & & Q1028 & \\
\hline$Q$ & 446 & 404414 & 735047 & 2 & -88 & & & & & & & & \\
\hline$Q$ & 447 & 404402 & 735039 & 2 & -89 & & & & & & & Q2400B & \\
\hline$Q$ & 448 & 404320 & 735014 & 7 & -53 & & & & & & & & \\
\hline $\mathrm{Q}$ & 449 & 404337 & 735017 & 1 & -90 & & & & & & & & \\
\hline $\mathrm{Q}$ & 450 & 404545 & 735022 & 10 & -72 & & & & & & & & \\
\hline Q & 451 & 404518 & 735038 & 17 & -142 & & & & & & & Q1730 & \\
\hline$Q$ & 452 & 404504 & 735037 & 4 & -87 & & & & & & & & \\
\hline
\end{tabular}


Table 9 Hydrogeologic units penetrated by wells and test holes in Kings, Queens, Nassau, Bronx, New York, and Richmond Countıes, New York-Continued

[Well locations are shown on plate 1, PRES, unit present but surface alttude not discernble, NR, no record—no record near altitudes indicated under remarks, Veatch, well number from numbering system employed in Veatch and others, 1906, BWS, New York City Bureau of Water Supply Well, $20 \mathrm{ft}$, "20 foot" clay may be present]

\begin{tabular}{|c|c|c|c|c|c|c|c|c|c|c|c|c|c|}
\hline \multirow{3}{*}{\multicolumn{2}{|c|}{$\begin{array}{c}\text { Well } \\
\text { Identification } \\
\text { number }\end{array}$}} & \multirow[b]{3}{*}{ Latitude } & \multirow[b]{3}{*}{ Longitude } & \multirow{2}{*}{\multicolumn{2}{|c|}{$\begin{array}{l}\text { Altitude of well, } \\
\text { in feet above or } \\
\text { below sea level }\end{array}$}} & \multicolumn{6}{|c|}{$\begin{array}{l}\text { Hydrogeologic unit penetrated and altitude of } \\
\text { unit surface, in feet above or below sea level }\end{array}$} & \multirow{3}{*}{$\begin{array}{c}\text { Located } \\
\text { near well }\end{array}$} & \multirow[b]{3}{*}{ Remarks } \\
\hline & & & & & & \multirow{2}{*}{$\begin{array}{c}\text { Gardiners } \\
\text { Clay }\end{array}$} & \multirow{2}{*}{$\begin{array}{l}\text { Jameco } \\
\text { Gravel }\end{array}$} & \multirow{2}{*}{$\begin{array}{l}\text { Magothy } \\
\text { aquifer }\end{array}$} & \multirow{2}{*}{$\begin{array}{c}\text { Raritan } \\
\text { confining unit }\end{array}$} & \multirow{2}{*}{$\begin{array}{c}\text { Lloyd } \\
\text { aquifer }\end{array}$} & \multirow[b]{2}{*}{ Bedrock } & & \\
\hline & & & & Top & Bottom & & & & & & & & \\
\hline Q & 453 & 404446 & 735535 & 68 & -79 & & & & & & -77 & Q1098 & \\
\hline Q & 455 & 404701 & 735048 & 37 & -63 & & & & -15 & & & & \\
\hline$Q$ & 460 & 404541 & 734529 & 11 & -446 & & & -2 & -146 & -297 & -399 & $\mathrm{Q} 484$ & \\
\hline $\mathrm{Q}$ & 461 & 404541 & 734529 & 11 & -366 & & & -2 & -146 & -297 & & Q484 & \\
\hline$Q$ & 462 & 404541 & 734529 & 7 & -398 & & & -4 & -162 & -275 & -393 & Q484 & \\
\hline$Q$ & 464 & 404541 & 734529 & 6 & -361 & & & -4 & -145 & -272 & & Q484 & \\
\hline$Q$ & 466 & 404541 & 734529 & 7 & -384 & & & 3 & -130 & -305 & & Q484 & \\
\hline Q & 468 & 404541 & 734529 & 2 & -398 & & & -19 & -138 & -300 & & Q484 & \\
\hline Q & 480 & 404541 & 734529 & 9 & -381 & & & -28 & -183 & -278 & & Q484 & \\
\hline$Q$ & 484 & 404541 & 734529 & 7 & -384 & & & -3 & -154 & -259 & & & \\
\hline$Q$ & 490 & 404704 & 734939 & 5 & -219 & & & & -45 & -135 & -219 & Q495 & \\
\hline Q & 491 & 404704 & 734939 & 9 & -205 & & & & -53 & -143 & & Q495 & \\
\hline Q & 492 & 404704 & 734939 & 6 & -222 & & & & -59 & -171 & & Q495 & \\
\hline$Q$ & 493 & 404704 & 734939 & 7 & -212 & & & & -44 & -168 & -208 & Q495 & \\
\hline$Q$ & 494 & 404704 & 734939 & 5 & -213 & & & & -59 & -153 & -208 & Q495 & \\
\hline $\mathrm{Q}$ & 495 & 404704 & 734939 & 4 & -189 & & & & -57 & -170 & & & \\
\hline $\mathrm{Q}$ & 542 & 403453 & 734959 & 6 & & -191 & -237 & -291 & -455 & -684 & & Q1071 & \\
\hline $\mathrm{Q}$ & 556 & 404200 & 734644 & 32 & -391 & -32 & & -106 & PRES & & & Q571 & \\
\hline$\hat{Q}$ & 557 & 404223 & 734800 & 58 & -139 & & & -56 & & & & Q1507 & \\
\hline$Q$ & 558 & 404054 & 734917 & 33 & -130 & -127 & & & & & & & \\
\hline $\mathrm{Q}$ & 559 & 404021 & 734839 & 16 & -281 & -97 & -161 & -198 & -256 & & & & \\
\hline$Q$ & 561 & 404139 & 734715 & 25 & -65 & -65 & & & & & & Q1839 & \\
\hline$Q$ & 562 & 404140 & 734716 & 23 & -658 & -67 & & -120 & -238 & -458 & -649 & & \\
\hline$Q$ & 563 & 404302 & 734513 & 70 & -68 & & & -24 & & & & Q564 & \\
\hline$Q$ & 564 & 404302 & 734513 & 70 & -229 & & & -24 & & & & & \\
\hline Q & 565 & 404202 & 734916 & 65 & -495 & -51 & -249 & & -351 & -415 & & & \\
\hline$Q$ & 566 & 404154 & 734937 & 61 & -231 & -84 & -202 & & & & & & \\
\hline$Q$ & 567 & 404254 & 734813 & 131 & -504 & & & -79 & PRES & -410 & & Q2137 & \\
\hline$\hat{Q}$ & 568 & 404200 & 734403 & 50 & -819 & & & -55 & -354 & -554 & -811 & & \\
\hline$Q$ & 571 & 404200 & 734644 & 30 & -602 & & & & NR & -480 & -600 & & NR 30 TO $\quad-479$ \\
\hline$Q$ & 572 & 404150 & 734719 & 25 & -758 & & & & NR & NR & -650 & Q1839 & NR 25 TO -649 \\
\hline Q & 580 & 404425 & 734341 & 115 & -553 & & & 15 & -293 & -469 & & & \\
\hline$\tilde{Q}$ & 581 & 404420 & 734340 & 112 & -570 & & & 0 & -272 & -466 & & Q1914 & \\
\hline Q & 582 & 404418 & 734339 & 110 & -591 & & & 16 & -280 & -461 & & Q1914 & \\
\hline$Q$ & 584 & 404257 & 734937 & 10 & -620 & & & & -120 & -320 & -440 & & \\
\hline
\end{tabular}


Table 9. Hydrogeologıc unıts penetrated by wells and test holes ın Kıngs, Queens, Nassau, Bronx, New York, and Rıchmond Countıes, New York-Contınued [Well locations are shown on plate 1, PRES, unit present but surface altitude not discernible, NR, no record-no record near altitudes indicated under remarks, Veatch, well number from numberng system employed in Veatch and others, 1906, BWS, New York City Bureau of Water Supply Well, 20ft, "20 foot" clay may be present]

\begin{tabular}{|c|c|c|c|c|c|c|c|c|c|c|c|c|c|}
\hline \multirow{2}{*}{\multicolumn{2}{|c|}{$\begin{array}{c}\text { Well } \\
\text { Identification } \\
\text { number } \\
\end{array}$}} & \multirow[b]{2}{*}{ Latitude } & \multirow[b]{2}{*}{ Longıtude } & \multirow{2}{*}{\multicolumn{2}{|c|}{$\begin{array}{l}\text { Alttude of well, } \\
\text { in feet above or } \\
\text { below sea level }\end{array}$}} & \multicolumn{6}{|c|}{$\begin{array}{l}\text { Hydrogeologic unit penetrated and altitude of } \\
\text { unit surface, in feet above or below sea level }\end{array}$} & \multirow[b]{2}{*}{$\begin{array}{c}\text { Located } \\
\text { near well }\end{array}$} & \multirow[b]{2}{*}{ Remarks } \\
\hline & & & & & & $\begin{array}{c}\text { Gardiners } \\
\text { Clay }\end{array}$ & $\begin{array}{l}\text { Jameco } \\
\text { Gravel }\end{array}$ & $\begin{array}{c}\text { Magothy } \\
\text { aquifer }\end{array}$ & $\begin{array}{c}\text { Raritan } \\
\text { confining unit }\end{array}$ & $\begin{array}{l}\text { Lloyd } \\
\text { aquifer }\end{array}$ & Bedrock & & \\
\hline$Q$ & 586 & 404347 & 735025 & 15 & -420 & & & & -135 & -325 & -414 & Q2413 & \\
\hline Q & 595 & 404458 & 734810 & 20 & -427 & & & PRES & -115 & -235 & & & \\
\hline Q & 597 & 404325 & 735001 & 0 & -89 & & & & & & & & \\
\hline$Q$ & 601 & 404524 & 735022 & 0 & -156 & & & & -89 & & & & \\
\hline$Q$ & 602 & 404453 & 735533 & 50 & -109 & & & & & & -85 & & \\
\hline Q & 603 & 404351 & 735558 & 69 & -133 & & & & & -53 & -110 & & \\
\hline$Q$ & 633 & 404004 & 735022 & 11 & -180 & & -117 & & & & & & \\
\hline$Q$ & 634 & 404024 & 735135 & 10 & -139 & -87 & -131 & & & & & & \\
\hline Q & 669 & 404748 & 735028 & 10 & -149 & & & & -66 & & & & Veatch 186 \\
\hline Q & 676 & 403909 & 734739 & 0 & -203 & -140 & -200 & & & & & & \\
\hline$Q$ & 678 & 403953 & 734526 & 10 & -261 & -99 & & -120 & & & & & \\
\hline$Q$ & 680 & 403957 & 734831 & 10 & -182 & -105 & -175 & & & & & Q1175 & \\
\hline Q & 681 & 403958 & 734715 & 5 & -151 & -84 & -137 & & & & & & \\
\hline Q & 682 & 404001 & 734653 & 7 & -251 & -76 & -147 & & & & & & \\
\hline$Q$ & 683 & 404001 & 734602 & 10 & -283 & -62 & -202 & -250 & & & & & \\
\hline$Q$ & 684 & 403959 & 734553 & 10 & -410 & -68 & -160 & -183 & & & & & \\
\hline Q & 689 & 404116 & 734822 & 40 & -82 & -71 & & & & & & & \\
\hline $\mathrm{Q}$ & 690 & 404119 & 734736 & 20 & -180 & -75 & -169 & & & & & & \\
\hline Q & 710 & 404605 & 734643 & 75 & 11 & & & 14 & & & & & \\
\hline$Q$ & 720 & 403955 & 734446 & 18 & -388 & -45 & -81 & -127 & & & & & \\
\hline Q & 721 & 403950 & 734358 & 22 & -390 & & & -80 & & & & & \\
\hline$Q$ & 722 & 403956 & 734344 & 17 & -373 & & & -41 & & & & & \\
\hline Q & 724 & 404049 & 734501 & 27 & -330 & & & -53 & & & & & \\
\hline Q & 952 & 404425 & 735523 & 29 & -28 & & & & & & & & \\
\hline$Q$ & 954 & 404536 & 735626 & 12 & -289 & & & & & & -15 & & \\
\hline Q & 957 & 404208 & 734810 & 45 & -137 & & & -49 & & & & & \\
\hline Q & 962 & 404506 & 735642 & 20 & -175 & & & & & & -25 & & \\
\hline$Q$ & 964 & 404546 & 735243 & 20 & -105 & & & & & & & & \\
\hline Q & 966 & 404440 & 735724 & 8 & -192 & & & & & & -37 & & \\
\hline$Q$ & 978 & 404443 & 735423 & 60 & -110 & & & & -42 & & & Q1620 & \\
\hline Q & 985 & 404207 & 734832 & 35 & -143 & & & -61 & & & & Q1037 & \\
\hline$\tilde{Q}$ & 1026 & 404446 & 735011 & 8 & -287 & & & & -72 & -234 & & Q1027 & \\
\hline$Q$ & 1027 & 404446 & 735013 & 8 & -275 & & & & -82 & -232 & & & \\
\hline$Q$ & 1028 & 404438 & 735039 & 5 & -419 & & & & & & -316 & & NR 5 TO -315 \\
\hline$Q$ & 1030 & 403451 & 735004 & 6 & $-1,043$ & -192 & -240 & -336 & -467 & -731 & -974 & & \\
\hline
\end{tabular}


Table 9. Hydrogeologic units penetrated by wells and test holes in Kıngs, Queens, Nassau, Bronx, New York, and Richmond Counties, New York—Contınued [Well locations are shown on plate 1, PRES, unit present but surface alttude not discernible, NR, no record—no record near alttides indicated under remarks, Veatch, well number from numbering system employed in Veatch and others, 1906, BWS, New York City Bureau of Water Supply Well, $20 \mathrm{ft}$, "20 foot" clay may be present]

\begin{tabular}{|c|c|c|c|c|c|c|c|c|c|c|c|c|}
\hline \multirow{3}{*}{$\begin{array}{c}\text { Well } \\
\text { Identification } \\
\text { number }\end{array}$} & \multirow[b]{3}{*}{ Latıtude } & \multirow[b]{3}{*}{ Longitude } & \multirow{2}{*}{\multicolumn{2}{|c|}{$\begin{array}{l}\text { Altitude of well, } \\
\text { in feet above or } \\
\text { below sea level }\end{array}$}} & \multicolumn{6}{|c|}{$\begin{array}{l}\text { Hydrogeologic unit penetrated and altitude of } \\
\text { unit surface, in feet above or below sea level }\end{array}$} & \multirow{3}{*}{$\begin{array}{l}\text { Located } \\
\text { near well }\end{array}$} & \multirow[b]{3}{*}{ Remarks } \\
\hline & & & & & \multirow{2}{*}{$\begin{array}{c}\text { Gardiners } \\
\text { Clay }\end{array}$} & \multirow{2}{*}{$\begin{array}{l}\text { Jameco } \\
\text { Gravel }\end{array}$} & \multirow{2}{*}{$\begin{array}{l}\text { Magothy } \\
\text { aquifer }\end{array}$} & \multirow{2}{*}{$\begin{array}{c}\text { Raritan } \\
\text { confining unit }\end{array}$} & \multirow{2}{*}{$\begin{array}{l}\text { Lloyd } \\
\text { aquifer }\end{array}$} & \multirow[b]{2}{*}{ Bedrock } & & \\
\hline & & & Top & Bottom & & & & & & & & \\
\hline Q 1032 & 404459 & 735138 & 40 & -223 & & & & -21 & -182 & -211 & & \\
\hline Q 1035 & 404215 & 734752 & 62 & -215 & & & -89 & & & & Q1965 & \\
\hline Q 1036 & 404209 & 734831 & 55 & -128 & & & -40 & & & & Q1037 & \\
\hline Q 1037 & 404209 & 734831 & 51 & -145 & & & -23 & & & & & \\
\hline Q 1041 & 404528 & 734441 & 5 & -188 & & & -76 & & & & Q1057 & \\
\hline Q 1042 & 404530 & 734442 & 5 & -199 & & & -76 & & & & Q1057 & \\
\hline Q 1043 & 404532 & 734442 & 5 & -120 & & & -73 & & & & Q1057 & \\
\hline Q 1045 & 404537 & 734443 & 5 & -181 & & & -61 & & & & Q1057 & \\
\hline Q 1048 & 404520 & 734437 & 6 & -177 & & & -93 & & & & Q1053 & \\
\hline Q 1049 & 404519 & 734439 & 6 & -154 & & & -109 & & & & Q1053 & \\
\hline Q 1053 & 404518 & 734440 & 12 & -190 & & & -132 & & & & & \\
\hline Q 1056 & 404523 & 734437 & 5 & -166 & & & -125 & & & & Q1057 & \\
\hline Q 1057 & 404527 & 734439 & 9 & -38 & & & -38 & & & & & \\
\hline Q 1063 & 404132 & 734540 & 32 & -112 & & & -29 & & & & Q1532 & \\
\hline Q 1064 & 404156 & 734826 & 35 & & -55 & & & & & & & \\
\hline Q 1071 & 403454 & 734956 & 12 & -851 & -188 & -240 & -268 & -468 & -737 & & & \\
\hline Q 1085 & 404348 & 735531 & 6 & -164 & -78 & & & PRES & & -158 & & \\
\hline Q 1086 & 404445 & 735210 & 52 & -297 & & & & -38 & -206 & -227 & Q1241 & \\
\hline Q 1087 & 404444 & 735211 & 52 & -66 & & & & -38 & & & Q1241 & \\
\hline Q 1093 & 404631 & 735449 & 53 & 11 & & & & & & 11 & & \\
\hline Q 1095 & 404359 & 734741 & 38 & -14 & & & -14 & & & & & \\
\hline Q 1098 & 404439 & 735534 & 72 & -143 & & & & & & -62 & & \\
\hline Q 1175 & 404002 & 734834 & 10 & -206 & -113 & -176 & & & & & & \\
\hline Q 1197 & 403958 & 734502 & 15 & -119 & -47 & -90 & -117 & & & & & \\
\hline Q 1221 & 404522 & 735624 & 17 & -161 & & & & & & -21 & & \\
\hline Q 1230 & 403539 & 734626 & 10 & -154 & & & & & & & & \\
\hline Q 1239 & 404218 & 734751 & 50 & -150 & & & -33 & & & & Q1965 & \\
\hline Q 1241 & 404445 & 735211 & 52 & -265 & & & & -8 & -204 & & & \\
\hline Q 1246 & 404520 & 735553 & 42 & -178 & & & & & & -21 & & \\
\hline Q 1257 & 404548 & 735542 & 30 & -120 & & & & & & -17 & & \\
\hline Q 1258 & 404446 & 735547 & 55 & -8 & & & & & & -8 & Q2333 & \\
\hline Q 1272 & 404525 & 735640 & 10 & -185 & & & & & & 8 & & \\
\hline Q 1274 & 404326 & 735449 & 15 & -65 & -40 & & & & & & & \\
\hline Q 1275 & 404217 & 734754 & 50 & -111 & & & -33 & & & & Q1965 & \\
\hline Q 1278 & 404313 & 735044 & 56 & -114 & & & -37 & & & & & \\
\hline
\end{tabular}


Table 9. Hydrogeologıc units penetrated by wells and test holes in Kıngs, Queens, Nassau, Bronx, New York, and Rıchmond Countıes, New York-Contınued [Well locations are shown on plate 1, PRES, unit present but surface alttude not discernible, NR, no record—no record near altitudes indicated under remarks, Veatch, well number from numberng system employed in Veatch and others, 1906, BWS, New York City Bureau of Water Supply Well, 20ft, "20 foot" clay may be present]

\begin{tabular}{|c|c|c|c|c|c|c|c|c|c|c|c|c|}
\hline \multirow{2}{*}{$\begin{array}{c}\text { Well } \\
\text { Identıfication } \\
\text { number }\end{array}$} & \multirow[b]{2}{*}{ Latıtude } & \multirow[b]{2}{*}{ Longitude } & \multicolumn{2}{|c|}{$\begin{array}{l}\text { Altitude of well, } \\
\text { in feet above or } \\
\text { below sea level }\end{array}$} & \multicolumn{6}{|c|}{$\begin{array}{l}\text { Hydrogeologic unit penetrated and altitude of } \\
\text { unit surface, in feet above or below sea level }\end{array}$} & \multirow[b]{2}{*}{$\begin{array}{l}\text { Located } \\
\text { near well }\end{array}$} & \multirow[b]{2}{*}{ Remarks } \\
\hline & & & $\begin{array}{l}\text { belov } \\
\text { Top }\end{array}$ & $\frac{\text { a level }}{\text { Bottom }}$ & $\begin{array}{c}\text { Gardıners } \\
\text { Clay }\end{array}$ & $\begin{array}{l}\text { Jameco } \\
\text { Gravel }\end{array}$ & $\begin{array}{c}\text { Magothy } \\
\text { aquifer }\end{array}$ & $\begin{array}{c}\text { Raritan } \\
\text { confinıng unit } \\
\end{array}$ & $\begin{array}{c}\text { Lloyd } \\
\text { aquifer }\end{array}$ & Bedrock & & \\
\hline Q 1291 & 404132 & 734537 & 42 & -29 & & & -27 & & & & Q1532 & \\
\hline Q 1293 & 404424 & 734350 & 115 & -565 & & & -23 & -255 & -475 & & & \\
\hline Q 1304 & 403952 & 734916 & 14 & -140 & -121 & -132 & & & & & & Veatch 195 \\
\hline Q 1305 & 403948 & 734538 & 12 & -166 & -66 & & -111 & & & & & Veatch 196 \\
\hline Q 1311 & 404250 & 734538 & 58 & -349 & & & -40 & & & & Q1957 & Veatch 220 \\
\hline Q 1314 & 404210 & 734803 & 38 & -177 & & & -100 & & & & & \\
\hline Q 1328 & 404456 & 735303 & 53 & -62 & & & & -59 & & & & \\
\hline Q 1352 & 404618 & 735157 & 13 & -195 & & & & & & -169 & & \\
\hline Q 1353 & 404756 & 734942 & 0 & -162 & & & & -74 & -92 & -142 & & \\
\hline Q 1372 & 404308 & 734357 & 80 & -142 & & & -31 & & & & Q3012 & \\
\hline Q 1373 & 404656 & 735029 & 50 & -212 & & & & 13 & -144 & -195 & Q1542 & \\
\hline Q 1374 & 404653 & 735030 & 55 & -200 & & & & 20 & -151 & -195 & Q1542 & \\
\hline Q 1376 & 404152 & 735109 & 83 & -128 & & -103 & -114 & & & & Q1379 & \\
\hline Q 1378 & 404120 & 735112 & 42 & -170 & & -111 & & & & & & \\
\hline Q 1379 & 404154 & 735107 & 83 & -127 & & -103 & -114 & & & & & \\
\hline Q 1383 & 403610 & 734514 & 26 & -224 & & & -114 & & & & & \\
\hline Q 1384 & 404308 & 734357 & 80 & -152 & & & -26 & & & & Q3012 & \\
\hline Q 1392 & 404227 & 734750 & 60 & -301 & & & -72 & -260 & & & Q1507 & \\
\hline Q 1400 & 404401 & 735229 & 20 & -282 & & & & -58 & -238 & -281 & & \\
\hline Q 1412 & 404259 & 735427 & 42 & -98 & & & & -78 & & & & \\
\hline Q 1423 & 404233 & 734630 & 55 & -247 & & & -85 & & & & Q2356 & \\
\hline Q 1447 & 404148 & 734847 & 45 & -90 & -84 & & & & & & & \\
\hline Q 1449 & 404107 & 734805 & 28 & -108 & -103 & & & & & & Q3157 & \\
\hline Q 1450 & 404207 & 734459 & 55 & -77 & & & -62 & & & & Q1815 & \\
\hline Q 1465 & 404604 & 735025 & 12 & -115 & & & & -59 & & & & \\
\hline Q 1472 & 404415 & 734657 & 70 & -184 & & & -75 & & & & Q3000 & \\
\hline Q 1477 & 404050 & 735022 & 34 & -144 & -82 & -111 & & & & & & \\
\hline Q 1483 & 404055 & 735118 & 25 & -159 & & -120 & -143 & & & & & \\
\hline Q 1493 & 404140 & 735041 & 45 & -98 & & & & & & & & \\
\hline Q 1497 & 404653 & 735030 & 55 & -169 & & & & 25 & -130 & -169 & Q1542 & \\
\hline Q 1498 & 404653 & 735030 & 55 & -169 & & & & 25 & -130 & -169 & Q1542 & \\
\hline Q 1502 & 404426 & 735614 & 15 & -78 & & & & & & -76 & QBWS2 & \\
\hline Q 1503 & 404316 & 734837 & 75 & -32 & & & -32 & & & & & \\
\hline Q 1507 & 404222 & 734750 & 58 & -99 & & & -94 & & & & & \\
\hline Q 1511 & 404139 & 735105 & 48 & -97 & & & & & & & & \\
\hline
\end{tabular}


$\$$ Table 9 Hydrogeologic units penetrated by wells and test holes in Kings, Queens, Nassau, Bronx, New York, and Richmond Countıes, New York—Contınued [Well locations are shown on plate 1, PRES, unt present but surface alttude not discernible, NR, no record—no record near alttudes indicated under remarks, Veatch, well number from numbering system employed in Veatch and others, 1906, BWS, New York City Bureau of Water Supply Well, 20ft, "20 foot" clay may be present]

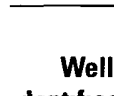

Well
Identificatıon

number
nentification

Q 1516

Q 1521

Q 1528

Q 1532

Q 1535

Q 1536

Q 1542

Q 1600

Q 1619

Q 1620

1629

Q 1630

Q 1632

Q 1635

Q 1638

Q 1640

Q 1678

Q 1695

Q 1730

Q 1736

Q 1738

$\begin{array}{ll}Q & 1747 \\ 0 & 1787\end{array}$

Q 1789

Q 1802

Q 1811

Q 1812

Q 1815

Q 1823

Q 1839

Q 1841

Q 1850

Q 1851

Q 1861

\begin{tabular}{|c|c|c|c|}
\hline \multirow[b]{2}{*}{ Latıtude } & \multirow[b]{2}{*}{ Longitude } & \multicolumn{2}{|c|}{$\begin{array}{l}\text { Altitude of well, } \\
\text { in feet above or } \\
\text { below sea level }\end{array}$} \\
\hline & & Top & Bottom \\
\hline 404539 & 734957 & 35 & -77 \\
\hline 404029 & 734553 & 20 & -162 \\
\hline 404137 & 735158 & 70 & -118 \\
\hline 404134 & 734542 & 40 & -414 \\
\hline 404249 & 734435 & 70 & -380 \\
\hline 404324 & 734554 & 190 & -83 \\
\hline 404653 & 735030 & 53 & -171 \\
\hline 404330 & 734503 & 98 & -356 \\
\hline 404554 & 735558 & 15 & -28 \\
\hline 404439 & 735413 & 60 & -173 \\
\hline 404249 & 734435 & 70 & -242 \\
\hline 403518 & 3734827 & 7 & -168 \\
\hline 404435 & 735608 & 18 & -45 \\
\hline 404510 & 735553 & 3 & -37 \\
\hline 404424 & 735615 & 13 & -60 \\
\hline 404617 & 734404 & 80 & -56 \\
\hline 404541 & 735032 & 12 & -258 \\
\hline 404615 & 734409 & 85 & -84 \\
\hline 404516 & 735035 & 10 & -260 \\
\hline 404617 & 734410 & 88 & -30 \\
\hline 404446 & 735635 & 15 & -131 \\
\hline 404323 & 734553 & 180 & -93 \\
\hline 404303 & 734816 & 110 & -138 \\
\hline 404552 & 734621 & 80 & -9 \\
\hline 404338 & 735115 & 90 & -72 \\
\hline 404151 & 734921 & 50 & -97 \\
\hline 404303 & 734816 & 110 & -145 \\
\hline 404207 & 734459 & 58 & -248 \\
\hline 404057 & 734854 & 40 & -242 \\
\hline 404145 & 734734 & 35 & -313 \\
\hline 404150 & 734719 & 25 & -61 \\
\hline 404423 & 734337 & 115 & -242 \\
\hline 404516 & 734230 & 132 & -71 \\
\hline 404341 & 735122 & 80 & -223 \\
\hline 404019 & 734717 & 9 & -176 \\
\hline
\end{tabular}

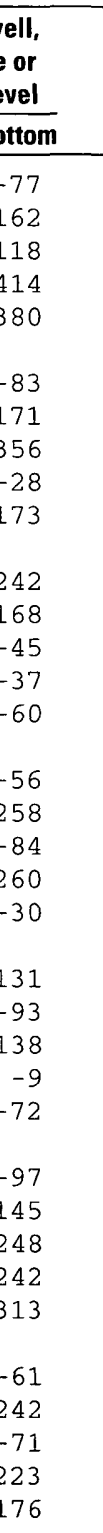

$\begin{array}{cc}\begin{array}{c}\text { Gardiners } \\ \text { Clay }\end{array} & \begin{array}{c}\text { Hydro } \\ \text { unit } \\ \text { Gravel }\end{array} \\ & \\ -44 & -126 \\ & -114\end{array}$

Hydrogeologic unit penetrated and altitude of

unit surface, in feet above or below sea level

Magothy Raritan Lloyd

aquifer confining unit aquifer Bedrock Located

Remarks

$\begin{array}{lll}-21 & -334 & \\ -39 & -356 & 01629\end{array}$

$\begin{array}{ll}-73 & \text { Q1747 }\end{array}$

$-283$

$-42-27$

$-35$

$-119$

-45
-37
-37

QBWS2 
Table 9 Hydrogeologıc units penetrated by wells and test holes in Kıngs, Queens, Nassau, Bronx, New York, and Rıchmond Countıes, New York-Contınued [Well locations are shown on plate 1, PRES, unit present but surface alttude not discermible, NR, no record—no record near alttudes indicated under remarks, Veatch, well number from numbering system employed in Veatch and others, 1906, BWS, New York City Bureau of Water Supply Well, 20ft, "20 foot" clay may be present]

\begin{tabular}{|c|c|c|c|c|c|c|c|c|c|c|c|c|}
\hline \multirow{3}{*}{$\begin{array}{c}\text { Well } \\
\text { Identification } \\
\text { number }\end{array}$} & \multirow[b]{3}{*}{ Latıtude } & \multirow[b]{3}{*}{ Longitude } & \multirow{2}{*}{\multicolumn{2}{|c|}{$\begin{array}{l}\text { Altitude of well, } \\
\text { in feet above or } \\
\text { below sea level }\end{array}$}} & \multirow{3}{*}{$\begin{array}{l}\text { Gardiners } \\
\text { Clay }\end{array}$} & \multicolumn{4}{|c|}{$\begin{array}{l}\text { Hydrogeologic unit penetrated and altitude of } \\
\text { unit surface, in feet above or below sea level }\end{array}$} & \multirow[b]{3}{*}{ Bedrock } & \multirow{3}{*}{$\begin{array}{c}\text { Located } \\
\text { near well }\end{array}$} & \multirow[b]{3}{*}{ Remarks } \\
\hline & & & & & & Jameco & Magothy & Raritan & Lloyd & & & \\
\hline & & & Top & Bottom & & Gravel & aquifer & confınıng unıt & aquifer & & & \\
\hline Q 1876 & 404019 & 734717 & 8 & -172 & -84 & -140 & & & & & & \\
\hline Q 1909 & 404515 & 734231 & 132 & -118 & & & 26 & & & & Q3003 & \\
\hline Q 1912 & 404516 & 735600 & 40 & -360 & & & & & & -30 & & \\
\hline Q 1914 & 404418 & 734342 & 120 & -138 & & & -14 & & & & & \\
\hline Q 1918 & 404332 & 735517 & 15 & -67 & -63 & & & & & & & \\
\hline Q 1922 & 404550 & 735338 & 30 & -103 & & & & -44 & & -102 & & \\
\hline Q 1923 & 404250 & 734538 & 65 & -246 & & & -22 & -225 & & & Q1957 & \\
\hline Q 1924 & 404141 & 734413 & 47 & -442 & & & -56 & -384 & & & Q2443 & \\
\hline Q 1926 & 404620 & 734740 & 90 & -200 & & & & 0 & -160 & & & \\
\hline Q 1929 & 403631 & 734542 & 9 & $-1,036$ & & & -123 & -579 & -777 & & Q1932 & \\
\hline Q 1930 & 403633 & 734545 & 8 & -122 & & & -118 & & & & Q1932 & \\
\hline Q 1931 & 403634 & 734544 & 8 & -132 & & & -124 & & & & Q1932 & \\
\hline Q 1932 & 403635 & 734542 & 8 & -126 & & & -118 & & & & & \\
\hline Q 1933 & 404443 & 735307 & 77 & -178 & & & & -47 & & -175 & & \\
\hline Q 1937 & 404540 & 734609 & 68 & -15 & & & 5 & & & & & \\
\hline Q 1941 & 404341 & 734850 & 78 & -36 & & & -29 & & & & & \\
\hline Q 1957 & 404250 & 734538 & 65 & -236 & & & -58 & -221 & & & & \\
\hline Q 1958 & 404141 & 734413 & 47 & -395 & & & -82 & -387 & & & Q2443 & \\
\hline Q 1965 & 404212 & 734753 & 36 & -227 & & & -91 & & & & & \\
\hline Q 1978 & 404451 & 735336 & 65 & -144 & & & & -5 & & -144 & Q2148 & \\
\hline Q 1979 & 404451 & 735335 & 65 & -25 & & & & -19 & & & Q2148 & \\
\hline Q 1982 & 404332 & 734429 & 90 & -303 & & & -9 & -274 & & & Q2188 & \\
\hline Q 1983 & 404217 & 734915 & 70 & -371 & -53 & & -204 & -243 & & & & \\
\hline Q 1984 & 404137 & 734522 & 45 & -356 & & & -35 & -336 & & & & \\
\hline Q 1985 & 404306 & 734637 & 145 & -155 & & & -62 & & & & Q2001 & \\
\hline Q 1999 & 404156 & 734613 & 35 & -366 & -40 & & -144 & -305 & & & & \\
\hline Q 2000 & 404332 & 734429 & 90 & -28 & & & -20 & & & & Q2188 & \\
\hline Q 2001 & 404259 & 734634 & 123 & -84 & & & & & & & & \\
\hline Q 2003 & 404156 & 734526 & 55 & -281 & & & -49 & & & & Q2028 & \\
\hline Q 2025 & 404648 & 735425 & 25 & -42 & & & & & & -31 & & \\
\hline Q 2026 & 404042 & 734337 & 40 & -410 & & & -48 & & & & & \\
\hline Q 2028 & 404156 & 734526 & 54 & -261 & & & -32 & & & & & \\
\hline Q 2080 & 404600 & 735518 & 45 & 9 & & & & & & 9 & & \\
\hline Q 2122 & 404205 & 735000 & 60 & -355 & -60 & -151 & -180 & -208 & -310 & & Q2332 & \\
\hline Q 2137 & 404254 & 734813 & 130 & -120 & & & -80 & & & & & \\
\hline
\end{tabular}




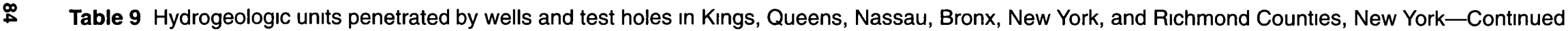
[Well locations are shown on plate 1, PRES, unit present but surface altitude not discernible, NR, no record—no record near altitudes indicated under remarks, Veatch, well number from numbering system employed in Veatch and others, 1906, BWS, New York City Bureau of Water Supply Well, 20ft, "20 foot" clay may be present]

\begin{tabular}{|c|c|c|c|c|c|c|c|c|c|c|c|c|}
\hline \multirow{3}{*}{$\begin{array}{c}\text { Well } \\
\text { Identıfication } \\
\text { number }\end{array}$} & \multirow[b]{3}{*}{ Latıtude } & \multirow[b]{3}{*}{ Longitude } & \multirow{2}{*}{\multicolumn{2}{|c|}{$\begin{array}{l}\text { Altitude of well, } \\
\text { in feet above or } \\
\text { below sea level }\end{array}$}} & \multirow{3}{*}{$\begin{array}{c}\text { Gardıners } \\
\text { Clay }\end{array}$} & \multicolumn{4}{|c|}{$\begin{array}{l}\text { Hydrogeologic unit penetrated and altitude of } \\
\text { unit surface, in feet above or below sea level }\end{array}$} & \multirow[b]{3}{*}{ Bedrock } & \multirow{3}{*}{$\begin{array}{l}\text { Located } \\
\text { near well }\end{array}$} & \multirow[b]{3}{*}{ Remarks } \\
\hline & & & & & & Jameco & Magothy & Raritan & Lloyd & & & \\
\hline & & & Top & Bottom & & Gravel & aquifer & confinıng unit & aquifer & & & \\
\hline Q 2138 & 404208 & 3735002 & 60 & -63 & & & & & & & Q2332 & \\
\hline Q 2140 & 404124 & 734930 & 48 & -274 & -76 & -183 & & -253 & & & Q2189 & \\
\hline Q 2144 & 404601 & 735011 & 12 & -134 & & & & & & & Q2592 & . \\
\hline Q 2148 & 404452 & 735337 & 65 & -20 & & & & -16 & & & & \\
\hline Q 2149 & 404126 & 734646 & 25 & -75 & -71 & & & & & & & \\
\hline Q 2188 & 404332 & 734429 & 90 & -192 & & & -19 & & & & & \\
\hline Q 2189 & 404124 & 734930 & 48 & -83 & -80 & & & & & & & \\
\hline Q 2195 & 404546 & 734949 & 25 & -67 & & & & -58 & & & & \\
\hline Q 2202 & 404312 & 735424 & 52 & -193 & & & & -95 & & -193 & & \\
\hline Q 2205 & 404117 & 734522 & 45 & -351 & & & -26 & & & & $Q 2243$ & \\
\hline Q 2206 & 404036 & 734436 & 25 & -108 & -48 & -89 & -105 & & & & & \\
\hline Q 2227 & 404056 & 734627 & 20 & -399 & -59 & -208 & -232 & & & & & \\
\hline Q 2243 & 404117 & 734522 & 45 & -62 & & & -3 & & & & & \\
\hline Q 2255 & 404224 & 734503 & 63 & -290 & & & -62 & & & & Q2300 & \\
\hline Q 2259 & 404216 & 734423 & 55 & -319 & & & -45 & & & & Q2276 & \\
\hline Q 2261 & 404404 & 735103 & 30 & -54 & & & -48 & & & & & \\
\hline Q 2266 & 403626 & 734457 & 22 & -110 & & & & & & & & \\
\hline Q 2272 & 404241 & 735359 & 95 & . -52 & & & & & & & & \\
\hline Q 2273 & 404434 & 735156 & 30 & -247 & & & & -154 & -202 & -234 & Q2394 & \\
\hline Q 2274 & 404740 & 734832 & 20 & -148 & & & & -9 & -109 & & & \\
\hline Q 2275 & 404216 & 734423 & 55 & -50 & & & & & & & Q2276 & \\
\hline Q 2276 & 404216 & 734423 & 55 & -319 & & & -45 & & & & & \\
\hline Q 2280 & 404622 & 735129 & 8 & -194 & & & & & & -192 & & \\
\hline Q 2282 & 404733 & 734747 & 9 & -188 & & & & -31 & -129 & -188 & & \\
\hline Q 2289 & 404012 & 735006 & 30 & -132 & & -103 & & & & & Q2384 & \\
\hline Q 2299 & 404224 & $=734503$ & 63 & -100 & & & -62 & & & & $Q 2300$ & \\
\hline Q 2300 & 404224 & 734503 & 63 & -220 & & & -62 & & & & & \\
\hline Q 2309 & 404602 & 735013 & 5 & -123 & & & & & & & Q2592 & \\
\hline Q 2321 & 404245 & 734406 & 65 & -309 & & & -82 & & & & Q2343 & \\
\hline Q 2325 & 404208 & 735002 & 60 & -180 & -76 & -149 & -180 & & & & Q2332 & \\
\hline Q 2329 & 404159 & 734629 & 30 & -79 & & & & & & & & \\
\hline Q 2331 & 404703 & 734905 & 65 & -40 & & & & -38 & & & & \\
\hline Q 2332 & 404208 & 735002 & 60 & -192 & -71 & -151 & -165 & & & & & \\
\hline Q 2333 & 404443 & 735601 & 25 & -12 & & & & & & -12 & & \\
\hline Q 2343 & 404245 & 734406 & 65 & -175 & & & -77 & & & & & \\
\hline
\end{tabular}


Table 9 Hydrogeologıc units penetrated by wells and test holes in Kıngs, Queens, Nassau, Bronx, New York, and Rıchmond Countıes, New York-Contınued

[Well locations are shown on plate 1, PRES, unit present but surface altitude not discernible, NR, no record-no record near altitudes indicated under remarks, Veatch, well number from numbernng system employed in Veatch and others, 1906, BWS, New York City Bureau of Water Supply Well, 20ft, "20 foot" clay may be present]

\begin{tabular}{|c|c|c|c|c|c|c|c|c|c|c|c|c|}
\hline \multirow{3}{*}{$\begin{array}{c}\text { Well } \\
\text { Identıfication } \\
\text { number } \\
\end{array}$} & \multirow[b]{3}{*}{ Latitude } & \multirow[b]{3}{*}{ Longitude } & \multirow{2}{*}{\multicolumn{2}{|c|}{$\begin{array}{l}\text { Alttudude of well, } \\
\text { in feet above or } \\
\text { below sea level }\end{array}$}} & \multicolumn{6}{|c|}{$\begin{array}{l}\text { Hydrogeologic unit penetrated and altitude of } \\
\text { unit surface, in feet above or below sea level }\end{array}$} & \multirow{3}{*}{$\begin{array}{c}\text { Located } \\
\text { near well }\end{array}$} & \multirow[b]{3}{*}{ Remarks } \\
\hline & & & & & \multirow{2}{*}{$\begin{array}{c}\text { Gardıners } \\
\text { Clay }\end{array}$} & \multirow{2}{*}{$\begin{array}{c}\text { Jameco } \\
\text { Gravel }\end{array}$} & \multirow{2}{*}{$\begin{array}{c}\text { Magothy } \\
\text { aquifer }\end{array}$} & \multirow{2}{*}{$\begin{array}{c}\text { Rarıtan } \\
\text { confıning unit } \\
\end{array}$} & \multirow{2}{*}{$\begin{array}{c}\text { Lloyd } \\
\text { aquifer }\end{array}$} & \multirow[b]{2}{*}{ Bedrock } & & \\
\hline & & & Top & Bottom & & & & & & & & \\
\hline Q 2349 & 403935 & 734515 & 10 & -80 & -70 & & & & & & & \\
\hline Q 2356 & 404234 & 734629 & 50 & -165 & & & -97 & & & & & \\
\hline Q 2361 & 404329 & 734827 & 74 & -262 & & & -33 & -198 & & & Q2409 & \\
\hline Q 2362 & 404320 & 734818 & 82 & -244 & & & -63 & -205 & & & & \\
\hline Q 2363 & 404343 & 734831 & 64 & -366 & & & -30 & -184 & -347 & & & \\
\hline Q 2364 & 404323 & 734838 & 74 & -264 & & & -32 & -177 & & & Q2374 & \\
\hline Q 2366 & 404559 & 735512 & 45 & 2 & & & & & & 2 & & \\
\hline Q 2373 & 404323 & 734838 & 74 & -193 & & & -31 & -181 & & & Q2374 & \\
\hline Q 2374 & 404323 & 734838 & 74 & -193 & & & -31 & -181 & & & & \\
\hline Q 2377 & 404510 & 735005 & 20 & -250 & & & & & & -248 & Q2402 & \\
\hline Q 2378 & 404718 & 734622 & 12 & -162 & & & & & & & & \\
\hline Q 2384 & 404022 & 734957 & 27 & -126 & & -111 & & & & & & \\
\hline Q 2385 & 404343 & 735008 & 5 & -99 & & & & & & & & \\
\hline Q 2386 & 404411 & 735042 & 5 & -130 & & & & -120 & & & $\mathrm{Q} 2400 \mathrm{~B}$ & \\
\hline Q 2390 & 404434 & 735159 & 35 & -252 & & & & -134 & -232 & & Q2394 & \\
\hline Q 2392 & 404349 & 735009 & 5 & -160 & & & & & & & & \\
\hline Q 2393 & 404434 & 735159 & 35 & -130 & & & & -129 & & & Q2394 & \\
\hline Q 2394 & 404434 & 735158 & 35 & -115 & & & & & & & & \\
\hline $\mathrm{Q} 2400 \mathrm{~A}$ & 404404 & 735040 & 13 & -104 & & & & -88 & & & $\mathrm{Q} 2400 \mathrm{~B}$ & \\
\hline $\mathrm{Q} 2400 \mathrm{~B}$ & 404404 & 735040 & 18 & -121 & & & & & & & & \\
\hline Q 2402 & 404509 & 735011 & 20 & -253 & & & & & & -253 & & \\
\hline Q 2404 & 404352 & 734449 & 160 & -250 & & & -30 & -250 & & & Q2435 & \\
\hline Q 2405 & 404248 & 734602 & 62 & -288 & & & -75 & -224 & & & $\mathrm{Q} 2432$ & \\
\hline Q 2408 & 404329 & 734827 & 74 & -85 & & & -32 & & & & Q2409 & \\
\hline Q 2409 & 404329 & 734827 & 74 & -207 & & & -32 & -183 & & & & \\
\hline Q 2410 & 404411 & 735019 & 5 & -195 & & & & & & & & \\
\hline Q 2413 & 404336 & 735028 & 8 & -127 & & & & -122 & & & & \\
\hline Q 2416 & 404504 & 735018 & 7 & -266 & & & & -54 & -200 & & Q2420 & \\
\hline Q 2417 & 404455 & 735052 & 10 & -293 & & & & & & & & \\
\hline Q 2419 & 404503 & 735019 & 7 & -264 & & & & -71 & -213 & & Q2420 & \\
\hline Q 2420 & 404503 & 735020 & 7 & -267 & & & & -73 & -216 & & & \\
\hline Q 2422 & 404025 & 734638 & 20 & -361 & -63 & -163 & -300 & & & & & \\
\hline Q 2426 & 403919 & 734420 & 6 & -238 & -44 & & -124 & & & & & \\
\hline Q 2430 & 404135 & 734402 & 47 & -413 & & & -53 & -383 & & & Q2443 & \\
\hline Q 2432 & 404248 & 734602 & 62 & -230 & & & -89 & 225 & & & & \\
\hline
\end{tabular}


\& Table 9. Hydrogeologic units penetrated by wells and test holes in Kings, Queens, Nassau, Bronx, New York, and Richmond Counties, New York-Contınued [Well locations are shown on plate 1, PRES, untt present but surface alttide not discernble, NR, no record—no record near altitudes indicated under remarks, Veatch, well number from numbering system employed in Veatch and others, 1906, BWS, New York City Bureau of Water Supply Well, $20 \mathrm{ft}$, "20 foot" clay may be present]

\begin{tabular}{|c|c|c|c|c|c|c|c|c|c|c|c|c|}
\hline \multirow{3}{*}{$\begin{array}{c}\text { Well } \\
\text { Identıfication } \\
\text { number }\end{array}$} & \multirow[b]{3}{*}{ Latitude } & \multirow[b]{3}{*}{ Longitude } & \multirow{2}{*}{\multicolumn{2}{|c|}{$\begin{array}{l}\text { Altitude of well, } \\
\text { in feet above or } \\
\text { below sea level }\end{array}$}} & \multirow{3}{*}{$\begin{array}{c}\text { Gardiners } \\
\text { Clay }\end{array}$} & \multicolumn{4}{|c|}{$\begin{array}{l}\text { Hydrogeologic unit penetrated and altitude of } \\
\text { unit surface, in feet above or below sea level }\end{array}$} & \multirow[b]{3}{*}{ Bedrock } & \multirow{3}{*}{$\begin{array}{l}\text { Located } \\
\text { near well }\end{array}$} & \multirow[b]{3}{*}{ Remarks } \\
\hline & & & & & & Jameco & Magothy & Rarıtan & Lloyd & & & \\
\hline & & & Top & Bottom & & Gravel & aquifer & confinıng unit & aquifer & & & \\
\hline Q 2435 & 404352 & 734449 & 160 & -202 & & & -34 & & & & & \\
\hline Q 2437 & 404329 & 735214 & 80 & -118 & & & -87 & -92 & & & & \\
\hline Q 2443 & 404135 & 734402 & 47 & -319 & & & -64 & & & & & ' \\
\hline Q 2445 & 404500 & 735606 & 26 & -84 & & & & & & -84 & & \\
\hline Q 2468 & 404627 & 735024 & 10 & -165 & & & & 10 & -140 & & & \\
\hline Q 2588 & 404512 & 734456 & 90 & -67 & & & -18 & & & & & \\
\hline Q 2592 & 404603 & 735008 & 12 & -238 & & & & & & -238 & & \\
\hline Q 2600 & 404506 & 734613 & 65 & -25 & & & -11 & & & & & \\
\hline Q 2685 & 404412 & 734538 & 105 & -41 & & & -28 & & & & & \\
\hline Q 2706 & 404245 & 735017 & 110 & -66 & & & -66 & & & & & \\
\hline Q 2712 & 404450 & 734402 & 185 & -53 & & & 18 & & & & & \\
\hline Q 2721 & 404507 & 735620 & 35 & -265 & & & & & & 15 & & \\
\hline Q 2765 & 404038 & 734450 & 25 & -425 & & & -40 & & & & Q2955 & \\
\hline Q 2791 & 404624 & 734835 & 80 & -60 & & & & 0 & & & & \\
\hline Q 2837 & 404237 & 735136 & 60 & -120 & -80 & & & & & & & \\
\hline Q 2955 & 404040 & 734451 & 25 & -430 & & & -41 & -425 & & & & \\
\hline Q 2987 & 404515 & 734231 & 132 & -327 & & & 3 & -274 & & & Q3003 & \\
\hline Q 2988 & 404402 & 734858 & 104 & -360 & & & -55 & -140 & -249 & & & \\
\hline Q 2990 & 404129 & 734849 & 50 & -264 & -115 & -164 & -224 & & & & & \\
\hline Q 2991 & 404310 & 734700 & 110 & -404 & & & -45 & -215 & -400 & & Q3014 & \\
\hline Q 3000 & 404413 & 3734701 & 70 & -209 & & & -66 & -200 & & & & \\
\hline Q 3002 & 404610 & 734621 & 70 & -47 & & & 1 & & & & & \\
\hline Q 3003 & 404515 & 5734231 & 140 & -183 & & & 21 & & & & & \\
\hline Q 3012 & 404310 & 734359 & 84 & -42 & & & -20 & & & & & \\
\hline Q 3014 & 404310 & 734700 & 110 & -227 & & & -37 & -211 & & & & \\
\hline Q 3020 & 404340 & 734231 & 95 & 0 & & & & & & & & \\
\hline Q 3026 & 404237 & 734554 & 60 & -275 & & & -85 & -257 & & & Q3034 & \\
\hline Q 3029 & 404059 & 734508 & 25 & -410 & & & -44 & -401 & & & Q3062 & \\
\hline Q 3030 & 404356 & 5735151 & 18 & -320 & & & -42 & -68 & -235 & -288 & Q3036 & \\
\hline Q 3036 & 404354 & 735200 & 20 & -279 & & & PRES & -40 & -225 & & & \\
\hline Q 3034 & 404237 & 734554 & 60 & -228 & & & -85 & & & & & \\
\hline Q 3056 & 404054 & 734403 & 40 & -429 & & & -86 & -425 & & & Q3083 & \\
\hline Q 3062 & 404059 & 734508 & 25 & -405 & & & -44 & -401 & & & & \\
\hline Q 3083 & 404056 & 5734406 & 40 & -323 & & & -49 & & & & & \\
\hline Q 3109 & 403933 & 3734829 & 22 & -427 & -109 & -202 & -234 & -376 & & & & \\
\hline
\end{tabular}


Table 9 Hydrogeologıc units penetrated by wells and test holes in Kıngs, Queens, Nassau, Bronx, New York, and Rıchmond Countıes, New York-Contınued [Well locations are shown on plate 1, PRES, unit present but surface alttude not discernible, NR, no record-no record near altitudes indicated under remarks, Veatch, well number from numbering system employed in Veatch and others, 1906, BWS, New York City Bureau of Water Supply Well, 20ft, "20 foot" clay may be present]

\begin{tabular}{|c|c|c|c|c|c|c|c|c|c|c|c|c|c|}
\hline \multirow{2}{*}{\multicolumn{2}{|c|}{$\begin{array}{c}\text { Well } \\
\text { Identification } \\
\text { number } \\
\end{array}$}} & \multirow[b]{2}{*}{ Latıtude } & \multirow[b]{2}{*}{ Longitude } & \multirow{2}{*}{\multicolumn{2}{|c|}{$\begin{array}{l}\text { Altitude of well, } \\
\text { in feet above or } \\
\text { below sea level } \\
\end{array}$}} & \multicolumn{6}{|c|}{$\begin{array}{l}\text { Hydrogeologic unit penetrated and altitude of } \\
\text { unit surface, in feet above or below sea level }\end{array}$} & \multirow[b]{2}{*}{$\begin{array}{l}\text { Located } \\
\text { near well }\end{array}$} & \multirow[b]{2}{*}{ Remarks } \\
\hline & & & & & & $\begin{array}{c}\text { Gardiners } \\
\text { Clay }\end{array}$ & $\begin{array}{c}\text { Jameco } \\
\text { Gravel }\end{array}$ & $\begin{array}{l}\text { Magothy } \\
\text { aquifer }\end{array}$ & $\begin{array}{c}\text { Raritan } \\
\text { Confining unit }\end{array}$ & $\begin{array}{c}\text { Lloyd } \\
\text { aquifer }\end{array}$ & Bedrock & & \\
\hline & 3110 & 403845 & 734757 & 10 & -461 & -104 & -186 & -346 & -431 & & & & \\
\hline & 3111 & 403850 & 734648 & 14 & -486 & -112 & -198 & -295 & -447 & & & & \\
\hline Q & 3112 & 403939 & 734728 & 11 & -418 & -99 & -145 & -293 & -381 & & & & \\
\hline Q & 3156 & 404050 & 734755 & 35 & -278 & -80 & -159 & & -278 & & & & \\
\hline Q & 3157 & 404107 & 734805 & 28 & -259 & -102 & -173 & -244 & -257 & & & & \\
\hline Q & BWS2 & 404424 & 735610 & 25 & -29 & & & & & & -29 & & \\
\hline & BWS3 & 404338 & 735414 & 29 & -158 & & & & -86 & & -158 & & \\
\hline$Q$ & BWS4 & 404446 & 735406 & 49 & -127 & & & & PRES & & -127 & & \\
\hline & BWS5 & 404612 & 735233 & 23 & -159 & & & & & & -159 & & \\
\hline & BWS7 & 404429 & 734632 & 61 & -535 & & & -32 & -151 & -302 & -482 & & \\
\hline & BWS9 & 404233 & 734940 & 115 & -537 & & & & & -388 & -498 & & \\
\hline & $3 W S 10$ & 404612 & 734611 & 61 & -411 & & & -21 & -99 & -274 & -381 & & \\
\hline & $3 W S 12$ & 404442 & 734850 & 16 & -406 & & & -52 & -86 & -276 & -332 & & \\
\hline & $3 W S 13$ & 404308 & 735257 & 102 & -296 & -148 & & & -254 & & -294 & & \\
\hline & 3WS14 & 404303 & 734914 & 85 & -490 & & & -55 & -185 & -330 & -450 & & \\
\hline & 3WS15 & 404612 & 734834 & 97 & -299 & & & & -45 & -185 & -258 & & \\
\hline & 3WS16 & 404530 & 735231 & 60 & -172 & & & & -96 & & -172 & & \\
\hline & 3WS17 & 404431 & 735258 & 38 & -242 & -67 & & & -82 & & -222 & & \\
\hline & 3WS18 & 404227 & 735106 & 77 & -429 & & & -66 & -166 & -366 & -429 & & \\
\hline & 3WS19 & 404655 & 734813 & 65 & -297 & & & & -5 & -137 & -225 & & \\
\hline $\mathrm{N}$ & 3 & 403931 & 734234 & 5 & -460 & -61 & & -107 & & & & & \\
\hline $\mathrm{N}$ & 6 & 403953 & 734316 & 10 & -328 & & & -52 & & & & & \\
\hline $\mathrm{N}$ & 10 & 404229 & 734246 & 51 & -351 & & & -79 & -351 & & & & \\
\hline $\mathrm{N}$ & 11 & 404224 & 734238 & 50 & -390 & & & -30 & -358 & & & N9151 & \\
\hline N & 23 & 404642 & 734405 & 18 & -449 & & & -54 & -178 & -280 & -416 & N9110 & \\
\hline $\mathrm{N}$ & 24 & 404735 & 734242 & 12 & -448 & & & & -171 & -261 & -416 & N9308 & \\
\hline $\mathrm{N}$ & 216 & 404955 & 734524 & 30 & -482 & & & & & & -200 & & \\
\hline $\mathrm{N}$ & 248 & 403946 & 734252 & 14 & -176 & & & -41 & & & & & \\
\hline $\mathrm{N}$ & 559 & 403713 & 734333 & 20 & -109 & -64 & & -109 & & & & & $20 \mathrm{ft}-25,-41$ \\
\hline N & 687 & 404743 & 734444 & 8 & -362 & & & & & -272 & -312 & & \\
\hline $\mathrm{N}$ & 914 & 403932 & 734243 & 10 & -104 & -60 & & -88 & & & & & \\
\hline & 1298 & 404655 & 734445 & 15 & -370 & & & -70 & -132 & -243 & -325 & & \\
\hline $\mathrm{N}$ & 1346 & 403850 & 734238 & 5 & -143 & -50 & & -142 & & & & & \\
\hline $\mathrm{N}$ & 1618 & 404631 & 734215 & 83 & -502 & & & -52 & -184 & -324 & -502 & N5110 & \\
\hline $\mathrm{N} 1$ & 1686 & 404723 & 734349 & 95 & -255 & & & 30 & -125 & & & N5576 & \\
\hline
\end{tabular}


\& Table 9. Hydrogeologıc units penetrated by wells and test holes in Kıngs, Queens, Nassau, Bronx, New York, and Rıchmond Countıes, New York-Contınued

[Well locations are shown on plate 1, PRES, unit present but surface altitude not discernble, NR, no record-no record near altitudes indicated under remarks, Veatch, well number from numbering system employed in Veatch and others, 1906, BWS, New York City Bureau of Water Supply Well, 20ft, "20 foot" clay may be present]

Well

Identification

number

N 1687

N 1802

N 1818

N 1835

N 1926

N 1958

N 2203

N 2214

N 2413

N 2578

N 2749

N 2597

N 3327

N 3443

N 3448

N 3705

N 3734

N 3851

N 3861

N 3862

N 3864

N 3866

N 3867

N 3905

N 4077

N 4173

N 4243

N 4405

N 4714

N 5076

N 5079

N 5099

N 5110

N 5576

\begin{tabular}{llrr} 
& & \multicolumn{2}{c}{$\begin{array}{c}\text { Alttude of well } \\
\text { in feet above or } \\
\text { below sea level }\end{array}$} \\
\cline { 3 - 4 } Latitude & Longitude & Top & Bottom \\
\hline 404723 & 734349 & 95 & -130 \\
404512 & 734210 & 132 & -618 \\
404532 & 734209 & 141 & -94 \\
404519 & 734210 & 122 & -148 \\
404841 & 734533 & 51 & -235 \\
& & & \\
404426 & 734148 & 116 & -641 \\
403806 & 734412 & 5 & -177 \\
404826 & 734504 & 47 & -245 \\
404126 & 734209 & 51 & -475 \\
404033 & 734312 & 25 & -478 \\
& & & \\
404751 & 734405 & 56 & -389 \\
403532 & 734034 & 6 & -1246 \\
404033 & 734312 & 25 & -545 \\
404815 & 734345 & 124 & -347 \\
403511 & 734150 & 7 & -1243 \\
& & & \\
403824 & 734159 & 24 & -166 \\
403711 & 734443 & 12 & -130 \\
404727 & 734355 & 82 & -105 \\
403751 & 734401 & 5 & -616 \\
403621 & 734418 & 8 & -787 \\
& & & \\
403827 & 734250 & 4 & -632 \\
403816 & 734142 & 6 & -446 \\
403912 & 734320 & 6 & -543 \\
404544 & 734151 & 134 & -636 \\
404324 & 734139 & 85 & -453 \\
404526 & 734159 & 130 & -130 \\
404541 & 734152 & 132 & -128 \\
404752 & 734403 & 57 & -419 \\
403515 & 734305 & 9 & $-1,108$ \\
403802 & 734444 & & -228 \\
404238 & 734203 & 71 & -392 \\
403742 & 734052 & 15 & -138 \\
404647 & 734235 & 189 & -245 \\
404722 & 734213 & 82 & -324 \\
& & 95 & -171 \\
& & &
\end{tabular}

Hydrogeologic unit penetrated and altutude of

unit surface, in feet above or below sea level

Gardıners Jameco Magothy Raritan Lloyd Located

Clay Gravel aquifer confining unit aquifer Bedrock near well

$\begin{array}{rlll}\text { PRES } & -113 & & \text { N5576 }\end{array}$

130
618

$-94$

$-148$

-641
-177
-245

-245
-475

475
478

$-70-142 \quad-15$

9

$-113$

$-427 \quad-616$

$-160 \quad-235$

$-158$

-41
-57

$\begin{array}{rrr}-103 & -117 & -137 \\ & & -67\end{array}$

$-83$

$$
\begin{aligned}
& -67 \\
& -32 \\
& -123
\end{aligned}
$$$$
-123
$$

$-49 \quad-136$

$-150$

$-130$

$-59 \quad-133$

$-203$

$-156$

$-545$

$-111-123$

$-206$

-180
-144

-144
41

PRES

$$
-513
$$$$
\begin{aligned}
& -513 \\
& -254
\end{aligned}
$$$$
-351
$$

$-431$

$-160$

$-235$$$
\begin{aligned}
& 12 \\
& 41
\end{aligned}
$$

$-84$

$-120$

$-141$

-155
-709

-233
-865

$-348$

$-31 \quad-392$

$-97$

$\begin{array}{rr}-122 & -392 \\ -50 & -199 \\ -63 & -188 \\ 29 & -110\end{array}$

Remarks

$20 \mathrm{ft}-47$

$20 \mathrm{ft}-16,-49$

$20 \mathrm{ft}-16$

$20 \mathrm{ft}-23$

$20 \mathrm{ft}-36$

N6581 20ft $-19,-37$

$20 \mathrm{ft}-22,-33$

$20 \mathrm{ft}-30,-51$

N4243

N6701 20ft -35 ,

veatch 272 
Table 9. Hydrogeologic units penetrated by wells and test holes in Kings, Queens, Nassau, Bronx, New York, and Richmond Counties, New York-Contınued [Well locations are shown on plate 1, PRES, unit present but surface altutude not discermble, NR, no record—no record near altitudes indicated under remarks, Veatch, well number from numbernng system employed in Veatch and others, 1906, BWS, New York City Bureau of Water Supply Well, 20ft, "20 foot" clay may be present]

\begin{tabular}{|c|c|c|c|c|c|c|c|c|c|c|c|c|c|c|}
\hline \multirow{2}{*}{\multicolumn{2}{|c|}{$\begin{array}{c}\text { Well } \\
\text { Identıficatıon } \\
\text { number }\end{array}$}} & \multirow[b]{2}{*}{ Latıtude } & \multirow[b]{2}{*}{ Longitude } & \multirow{2}{*}{\multicolumn{2}{|c|}{$\begin{array}{l}\text { Altitude of well, } \\
\text { in feet above or } \\
\text { below sea level } \\
\end{array}$}} & \multicolumn{6}{|c|}{$\begin{array}{l}\text { Hydrogeologic unit penetrated and altitude of } \\
\text { unit surface, in feet above or below sea level }\end{array}$} & \multirow[b]{2}{*}{$\begin{array}{l}\text { Located } \\
\text { near well }\end{array}$} & \multirow[b]{2}{*}{ Remarks } & \\
\hline & & & & & & $\begin{array}{c}\text { Gardıners } \\
\text { Clay }\end{array}$ & $\begin{array}{l}\text { Jameco } \\
\text { Gravel }\end{array}$ & $\begin{array}{c}\text { Magothy } \\
\text { aquifer }\end{array}$ & $\begin{array}{c}\text { Raritan } \\
\text { confınıng unit } \\
\end{array}$ & $\begin{array}{l}\text { Lloyd } \\
\text { aquifer }\end{array}$ & Bedrock & & & \\
\hline $\mathrm{N}$ & 5731 & 403944 & 734319 & 15 & -87 & & & -58 & & & & & $20 \mathrm{ft}-34$ & -48 \\
\hline $\mathrm{N}$ & 5884 & 404756 & 734258 & 68 & -160 & & & 36 & -95 & & & & & \\
\hline $\mathrm{N}$ & 6455 & 403942 & 734245 & 15 & -69 & & & -46 & & & & & & \\
\hline $\mathrm{N}$ & 6467 & 403810 & 734331 & 4 & -694 & -55 & -132 & -191 & -571 & & & & $20 \mathrm{ft}-21$ & -36 \\
\hline $\mathrm{N}$ & 6468 & 403840 & 734330 & 5 & -699 & -52 & -134 & -230 & -530 & & & & $20 \mathrm{ft}-29$ & -33 \\
\hline $\mathrm{N}$ & 6469 & 403810 & 734313 & 6 & -597 & -66 & -131 & -150 & -569 & & & & $20 \mathrm{ft}$ & -26 \\
\hline $\mathrm{N}$ & 6581 & 403827 & 734250 & 8 & -612 & -61 & -131 & -207 & -579 & & & & & \\
\hline $\mathrm{N}$ & 6610 & 403641 & 734331 & 9 & -235 & -79 & -100 & -121 & & & & & $20 \mathrm{ft}-24$ & -40 \\
\hline $\mathrm{N}$ & 6701 & 403517 & 734306 & 11 & -846 & -77 & -133 & -149 & -716 & & & & & \\
\hline $\mathrm{N}$ & 6706 & 403713 & 734159 & 6 & -737 & -68 & -125 & -155 & -628 & & & & $20 \mathrm{ft}-19$, & -33 \\
\hline $\mathrm{N}$ & 6813 & 403936 & 734309 & 10 & -228 & & & -69 & & & & & & \\
\hline $\mathrm{N}$ & 6925 & 404750 & 734446 & 11 & -274 & & & & -159 & -190 & & & & \\
\hline $\mathrm{N}$ & 7445 & 404515 & 734122 & 120 & -333 & & & 16 & PRES & & & & & \\
\hline $\mathrm{N}$ & 7613 & 404814 & 734518 & 38 & -197 & & & & & -147 & & & & \\
\hline $\mathrm{N}$ & 7770 & 404827 & 734454 & 43 & -267 & & & & & -178 & & & & \\
\hline $\mathrm{N}$ & 8109 & 403844 & 734233 & 5 & -148 & -52 & & -147 & & & & & $20 \mathrm{ft}-28$ & \\
\hline $\mathrm{N}$ & 8221 & 404922 & 734500 & 75 & -215 & & & & & -155 & & & & \\
\hline $\mathrm{N}$ & 8342 & 404642 & 734405 & 18 & -425 & & & -81 & -179 & -277 & -421 & N9110 & & \\
\hline $\mathrm{N}$ & 8375 & 404654 & 734223 & 110 & -454 & & & -66 & -174 & -325 & & N8456 & & \\
\hline $\mathrm{N}$ & 8455 & 404940 & 734446 & 55 & -224 & & & & & & -205 & & & \\
\hline $\mathrm{N}$ & 8456 & 404656 & 734226 & 105 & -519 & & & -73 & -182 & -342 & -510 & & & \\
\hline $\mathrm{N}$ & 8466 & 403803 & 734142 & 11 & -463 & -69 & & -129 & & & & & $20 \mathrm{ft}-20$ & \\
\hline $\mathrm{N}$ & 8821 & 404533 & 734154 & 133 & -107 & & & 18 & & & & N8840 & & \\
\hline $\mathrm{N}$ & 8840 & 404532 & 734151 & 122 & -118 & & & 22 & & & & & & \\
\hline $\mathrm{N}$ & 8964 & 404635 & 734356 & 47 & -188 & & & -143 & -173 & & & & & \\
\hline $\mathrm{N}$ & 9110 & 404640 & 734410 & 15 & -371 & & & -90 & -174 & -281 & & & & \\
\hline $\mathrm{N}$ & 9151 & 404224 & 734238 & 50 & -386 & & & -24 & -383 & & & & & \\
\hline $\mathrm{N}$ & 9308 & 404735 & 734240 & 12 & -431 & & & & -144 & -243 & -419 & & & \\
\hline $\mathrm{N}$ & 9532 & 403948 & 734218 & 10 & -130 & -70 & & -88 & & & & & & \\
\hline $\mathrm{N}$ & 9567 & 403846 & 734029 & 25 & -115 & -43 & & -63 & & & & & & \\
\hline
\end{tabular}


Table 10. Selected chemical analyses of ground water sampled from observatıon wells in Kıngs, Queens, and western Nassau Countıes, New York $\left[\mu \mathrm{s} / \mathrm{cm}\right.$, microsiemens per centımeter at 25 degrees Celsius, $\mathrm{mg} / \mathrm{L}$, milligrams per liter, $\mu \mathrm{g} / \mathrm{L}$, micrograms per liter, ${ }^{\circ} \mathrm{C}$, degrees Celsius, -- , analysis not avallable, <, less than, >, greater than, NTU, Nephelometric turbidity unit, Neg, negligible, Upglac, upper glacial aquifer, Jameco, Jameco aquifer, Lloyd, Lloyd aquifer, Mag, Magothy aquifer, Rar, Raritan confinıng unit]

\begin{tabular}{|c|c|c|c|c|c|c|c|c|c|c|c|c|c|c|}
\hline $\begin{array}{c}\text { Well } \\
\text { number }\end{array}$ & Latıtude & Longitude & \multicolumn{2}{|c|}{$\begin{array}{l}\text { Screened interval, } \\
\text { in feet above or } \\
\text { below sea level }\end{array}$} & Aquifer & \multirow{2}{*}{$\begin{array}{c}\text { Date } \\
\text { sampled' } \\
6 / 14 / 83\end{array}$} & \multirow{2}{*}{$\begin{array}{c}\begin{array}{c}\text { Specıfıc } \\
\text { conductance } \\
\text { ( } \boldsymbol{\mu s} / \mathbf{c m})\end{array} \\
1,370\end{array}$} & $\underset{\text { (units) }}{\mathrm{pH}}$ & $\begin{array}{c}\text { Field } \\
\text { temperature } \\
\left({ }^{\circ} \mathrm{C}\right) \\
\end{array}$ & \multirow{2}{*}{$\begin{array}{c}\begin{array}{c}\text { Color } \\
\text { (unit) }\end{array} \\
4\end{array}$} & $\begin{array}{l}\text { Turbıdıty } \\
\text { (NTU) }\end{array}$ & \multirow{2}{*}{$\begin{array}{c}\begin{array}{c}\text { Hardness } \\
(\mathrm{mg} / \mathrm{L} \text { as }\end{array} \\
\left.\mathrm{CaCO}_{3}\right)\end{array}$} & \multirow{2}{*}{$\begin{array}{c}\begin{array}{c}\text { Calcium, } \\
\text { total (mg/L } \\
\text { as Ca) }\end{array} \\
97\end{array}$} & \multirow{2}{*}{$\begin{array}{c}\begin{array}{c}\text { Magnesium, } \\
\text { total }(\mathbf{m g} / \mathbf{L} \\
\text { as } \mathbf{M g})\end{array} \\
46\end{array}$} \\
\hline K 922 & 403919 & 740027 & -117 & to -138 & Jam & & & 76 & 12 & & 04 & & & \\
\hline \multirow[t]{3}{*}{ K1189 } & 403918 & 740043 & -119 & to -140 & Jam & $3 / 11 / 81$ & 1,400 & 77 & 15 & 6 & 20 & 280 & 60 & 31 \\
\hline & & & & & & $6 / 14 / 83$ & 1,470 & 76 & 15 & 60 & 59 & 340 & 88 & 42 \\
\hline & 403849 & 735852 & -14 & to -19 & Upglac & $2 / 18 / 81$ & 890 & 73 & 155 & 2 & 3 & 400 & -- & -- \\
\hline \multirow[b]{2}{*}{ K1678 } & & & & & & $9 / 19 / 83$ & 611 & 71 & 155 & -- & 3 & 360 & 90 & 22 \\
\hline & 403549 & 735701 & -99 & to -109 & Upglac & $4 / 7 / 81$ & 4,560 & 76 & 13 & 220 & $>25$ & 880 & 300 & 32 \\
\hline & & & & & & $8 / 3 / 83$ & 3,690 & 77 & 16 & 10 & 9 & 740 & 120 & 74 \\
\hline \multirow[t]{3}{*}{ K1689 } & 403742 & 735839 & -18 & to -26 & Upglac & $2 / 25 / 81$ & 860 & 73 & 195 & 3 & 3 & 96 & -- & 50 \\
\hline & & & & & & $9 / 6 / 83$ & 164 & 70 & -- & 5 & 3 & 340 & 53 & 52 \\
\hline & 404146 & 735713 & -66 & to -77 & Upglac & $4 / 9 / 81$ & 490 & 73 & 15 & 18 & 53 & 170 & 29 & 24 \\
\hline & & & & & & $6 / 14 / 83$ & 920 & 71 & 15 & 5 & 4 & 390 & 110 & 35 \\
\hline & 403524 & 735834 & -19 & to -45 & Upglac & $2 / 12 / 81$ & 1,210 & 69 & 7 & 4 & 4 & 160 & -- & -- \\
\hline \multirow{2}{*}{ K2407 } & & & & & & $8 / 25 / 83$ & 1,600 & 66 & 17 & 9 & 8 & 160 & 98 & 70 \\
\hline & 403643 & 740131 & -42 & to -53 & Upglac & $4 / 28 / 81$ & 600 & 76 & 15 & 3 & 12 & 290 & 77 & 24 \\
\hline & & & & & & $8 / 9 / 83$ & 610 & 74 & 15 & -- & -- & 300 & 90 & 19 \\
\hline \multirow[t]{3}{*}{ K2482 } & 403945 & 735742 & -35 & to -50 & Upglac & $3 / 19 / 81$ & 720 & 74 & 14 & 7 & 4 & 280 & 62 & 30 \\
\hline & & & & & & $8 / 11 / 83$ & 726 & 76 & 17 & 4 & 4 & 290 & 50 & 34 \\
\hline & 403426 & 735832 & -173 & to -199 & Jam & $3 / 23 / 81$ & $>8,000$ & 72 & 13 & 5 & 21 & 5,200 & 320 & 1,100 \\
\hline & & & & & & $6 / 22 / 83$ & $>9,000$ & 72 & 13 & 12 & 36 & 5,300 & 320 & 980 \\
\hline K2511 & 403427 & 735833 & -159 & to -185 & Jam & $6 / 22 / 83$ & $>9,000$ & 73 & -- & 11 & 2 & 5,700 & 350 & 1,200 \\
\hline K2582 & 403732 & 735737 & -153 & to -184 & Jam & $9 / 22 / 83$ & 980 & 78 & 18 & 8 & 6 & 340 & 65 & 49 \\
\hline $\begin{array}{c}\text { Well } \\
\text { number }\end{array}$ & $\begin{array}{l}\text { Date } \\
\text { sampl }\end{array}$ & led $^{\prime}$ & $\begin{array}{c}\text { Sodium, } \\
\text { total (mg/L } \\
\text { as } \mathrm{Na}) \\
\end{array}$ & $\begin{array}{c}\text { Potassium, } \\
\text { total (mg/L } \\
\text { as K) }\end{array}$ & $\begin{array}{c}\text { Alkalınity } \\
\text { (mg/L as } \\
\mathrm{CaCO}_{3} \text { ) }\end{array}$ & $\begin{array}{c}\text { Sulfate, } \\
\text { dissolved } \\
\left(\mathrm{mg}_{\mathrm{L}} \mathrm{L} \text { as SO} \mathrm{S}_{4}\right) \\
\end{array}$ & $\begin{array}{c}\text { Chloride, } \\
\text { dissolved } \\
\text { (mg/L as } \mathrm{CL} \text { ) }\end{array}$ & $\begin{array}{c}\text { Flouride, } \\
\text { total (mg/L } \\
\text { as F) }\end{array}$ & $\begin{array}{c}\text { Total } \\
\text { dissolved } \\
\text { solıds (mg/L) } \\
\end{array}$ & $\begin{array}{l}\text { Nitro } \\
\text { nitrat } \\
\text { /mg/l }\end{array}$ & $\begin{array}{l}\text { n, as } \\
\text { total } \\
\text { is N) }\end{array}$ & $\begin{array}{l}\text { Nitrogen as } \\
\text { mmonia, total } \\
\text { (mg/L as N) } \\
\end{array}$ & $\begin{array}{c}\text { Arsenic, } \\
\text { total }(\mu \mathrm{g} / \mathrm{L} \\
\text { as As) }\end{array}$ & $\begin{array}{c}\text { Cadmıum, } \\
\text { total }(\mu \mathrm{g} / \mathrm{L} \\
\text { as Cd) } \\
\end{array}$ \\
\hline K 922 & $6 / 14 /$ & 183 & 130 & 10 & 190 & 97 & 270 & 02 & 936 & & & $0 \quad 04$ & $<50$ & $<10$ \\
\hline K1189 & $3 / 11 /$ & 181 & 200 & 10 & 180 & 95 & 250 & -- & 822 & & & 06 & -- & $<10$ \\
\hline & $6 / 14 /$ & 183 & 160 & 13 & 170 & 94 & 310 & 2 & 996 & & 0 & 01 & $<50$ & $<10$ \\
\hline K1673 & $2 / 18 /$ & 181 & -- & -- & 220 & 86 & 130 & -- & 616 & & 4 & 09 & $<50$ & $<10$ \\
\hline & $9 / 19 /$ & 183 & 40 & 4 & 270 & 48 & 96 & 3 & 562 & & 2 & $<02$ & $<50$ & $<10$ \\
\hline K1678 & $4 / 7 /$ & /81 & 700 & 14 & 96 & 260 & 1,300 & 1 & -- & & 0 & $<03$ & -- & $<10$ \\
\hline & $8 / 3 /$ & 183 & 510 & 9 & 100 & 190 & 30 & 2 & 2,460 & $>1$ & & -- & $<50$ & $<10$ \\
\hline K1689 & $2 / 25 /$ & 181 & 40 & 3 & 240 & 65 & 84 & -- & 560 & & 6 & 03 & $<50$ & $<10$ \\
\hline & $9 / 6 /$ & 183 & 45 & 6 & 220 & 38 & 72 & 3 & 555 & & & $<03$ & $<50$ & $<10$ \\
\hline K2040 & $4 / 9 /$ & 181 & 38 & 2 & 98 & 50 & 80 & 1 & -- & & & 18 & -- & $<10$ \\
\hline & $6 / 14 /$ & 183 & 110 & 4 & 230 & 87 & 94 & 2 & 619 & & & 01 & $<50$ & $<10$ \\
\hline K2407 & $2 / 12 /$ & 181 & -- & -- & 200 & 78 & 230 & -- & 798 & & 3 & 05 & $<50$ & $<10$ \\
\hline & $8 / 25 /$ & 183 & 110 & 7 & 38 & $<50$ & 110 & 3 & -- & & 7 & $<03$ & $<50$ & $<10$ \\
\hline K2412 & $4 / 28 /$ & 181 & 15 & -- & 400 & -- & 21 & 2 & -- & & & 05 & -- & $<10$ \\
\hline & $8 / 9 /$ & 183 & 13 & 3 & 180 & 70 & 39 & 1 & 419 & & 6 & $<03$ & $<50$ & $<10$ \\
\hline K2482 & $3 / 19 /$ & 181 & 41 & 3 & 180 & 88 & 70 & 2 & 478 & & 6 & $<03$ & -- & $<10$ \\
\hline & $8 / 11 /$ & 183 & 40 & 4 & 200 & 60 & 68 & 3 & 496 & & 5 & $<03$ & $<50$ & $<10$ \\
\hline K2510 & $3 / 23 /$ & 181 & 8,000 & 360 & 150 & 2,400 & 15,000 & 6 & 29,200 & & 3 & 03 & $<20$ & $<10$ \\
\hline & $6 / 22 /$ & 183 & 7,000 & 400 & 150 & 2,300 & 16,000 & 6 & 40,100 & & -- & 01 & $<50$ & $<10$ \\
\hline K2511 & $6 / 22 /$ & 183 & 8,200 & 400 & 150 & 2,300 & 18,000 & 7 & 42,000 & & -- & 05 & -- & $<10$ \\
\hline K2582 & $9 / 22 /$ & 183 & 43 & 3 & 120 & 95 & 170 & 3 & 634 & $>1$ & & $<03$ & $<50$ & $<10$ \\
\hline
\end{tabular}


Table 10. Selected chemıcal analyses of ground water sampled from observatıon wells in Kıngs, Queens, and western Nassau Countıes, New York-Contınued $\left[\mu \mathrm{s} / \mathrm{cm}\right.$, microsiemens per centımeter at 25 degrees Celsius, $\mathrm{mg} / \mathrm{L}$, milligrams per liter, $\mu \mathrm{g} / \mathrm{L}$, micrograms per liter, ${ }^{\circ} \mathrm{C}$, degrees Celsius, -- , analysis not avallable, $<$, less than, $>$, greater than, NTU, Nephelometnc turbidity unit, Neg, negligible, Upglac, upper glacial aquifer, Jameco, Jameco aquifer, Lloyd, Lloyd aquifer, Mag, Magothy aquifer, Rar, Rartan confinıng unit]

\begin{tabular}{|c|c|c|c|c|c|c|c|c|c|c|c|}
\hline $\begin{array}{c}\text { Well } \\
\text { number }\end{array}$ & $\begin{array}{c}\text { Date } \\
\text { sampled }\end{array}$ & $\begin{array}{c}\text { Chromium, } \\
\text { total }(\mu \mathrm{g} / \mathrm{L} \\
\text { as } \mathrm{Cr})\end{array}$ & $\begin{array}{l}\text { Copper, } \\
\text { total }(\mu \mathrm{g} / \mathrm{L} \\
\text { as } \mathrm{Cu})\end{array}$ & $\begin{array}{c}\text { Iron, } \\
\text { total }(\mu \mathrm{g} / \mathrm{L} \\
\text { as } \mathrm{Fe})\end{array}$ & $\begin{array}{c}\text { Lead, } \\
\text { total }(\mu \mathrm{g} / \mathrm{L} \\
\text { as } \mathrm{Pb})\end{array}$ & $\begin{array}{c}\text { Manganese, } \\
\text { total }(\mu g / L \\
\text { as } M n)\end{array}$ & $\begin{array}{c}\text { Mercury, } \\
\text { total }(\mu \mathrm{g} / \mathrm{L} \\
\text { as } \mathrm{Hg})\end{array}$ & $\begin{array}{c}\text { Selenium, } \\
\text { total }(\mu \mathrm{g} / \mathrm{L} \\
\text { as } \mathrm{Se})\end{array}$ & $\begin{array}{c}\text { Silver, } \\
\text { total }(\mu \mathrm{g} / \mathrm{L} \\
\text { as } \mathrm{Ag})\end{array}$ & $\begin{array}{c}\text { Zinc, } \\
\text { total }(\mu \mathrm{g} / \mathrm{L} \\
\text { as } \mathrm{Zn})\end{array}$ & $\begin{array}{l}\text { Linear } \\
\text { alkyl } \\
\text { sulfonate }\end{array}$ \\
\hline K 922 & $6 / 14 / 83$ & $<30$ & 30 & 190 & $<30$ & 10 & $<1$ & $<10$ & $<50$ & 40 & neg \\
\hline K1189 & $6 / 14 / 83$ & $<30$ & 50 & 230 & $<30$ & 300 & $<1$ & $<10$ & $<50$ & 30 & neg \\
\hline \multirow[t]{2}{*}{ K1673 } & $2 / 18 / 81$ & $<40$ & 10 & 30 & $<10$ & 30 & $<1$ & $<10$ & $<30$ & 40 & neg \\
\hline & $9 / 19 / 83$ & $<30$ & 10 & 140 & $<30$ & 10 & -. & $<10$ & $<50$ & 40 & neg \\
\hline \multirow[t]{2}{*}{ K1678 } & $4 / 7 / 81$ & $<50$ & 30 & 100 & $<30$ & 30 & $<1$ & -- & $<10$ & 40 & neg \\
\hline & $8 / 3 / 83$ & $<30$ & 10 & 150 & 40 & 30 & $<1$ & $<10$ & $<50$ & 90 & neg \\
\hline \multirow[t]{2}{*}{ K1689 } & $2 / 25 / 81$ & $<50$ & 40 & 100 & $<10$ & $<10$ & $<1$ & $<10$ & $<30$ & 50 & neg \\
\hline & $9 / 6 / 83$ & $<30$ & 120 & 80 & 80 & 30 & $<1$ & $<10$ & $<50$ & 380 & neg \\
\hline \multirow[t]{2}{*}{ K2040 } & $4 / 9 / 81$ & $<50$ & 10 & 690 & $<30$ & 40 & $<1$ & -- & $<10$ & 2,000 & neg \\
\hline & $6 / 14 / 83$ & $<30$ & 20 & 70 & $<30$ & 10 & $<1$ & $<10$ & $<50$ & 40 & neg \\
\hline \multirow[t]{2}{*}{ K2407 } & $2 / 12 / 81$ & $<40$ & 10 & 40 & $<10$ & 440 & $<1$ & $<10$ & $<30$ & 60 & neg \\
\hline & $8 / 25 / 83$ & $<30$ & 230 & 160 & 190 & 60 & $<1$ & $<10$ & $<50$ & 90 & neg \\
\hline \multirow[t]{2}{*}{ K2412 } & $4 / 28 / 81$ & $<50$ & 20 & 180 & $<30$ & 30 & -- & -- & $<10$ & 50 & -- \\
\hline & $8 / 9 / 83$ & $<30$ & 10 & 60 & $<30$ & 20 & $<1$ & $<10$ & $<50$ & 30 & neg \\
\hline \multirow[t]{2}{*}{ K2482 } & $3 / 19 / 81$ & $<50$ & 10 & 100 & $<30$ & $<10$ & $<1$ & -- & $<20$ & 10 & -- \\
\hline & $8 / 11 / 83$ & $<30$ & 40 & 100 & $<30$ & 20 & $<1$ & $<10$ & $<50$ & 20 & neg \\
\hline K2511 & $6 / 22 / 83$ & 60 & 70 & 380 & 70 & 3,500 & $<1$ & $<10$ & $<50$ & 50 & neg \\
\hline K2582 & $9 / 22 / 83$ & $<30$ & 10 & 750 & 120 & 20 & $<1$ & $<10$ & $<50$ & 80 & neg \\
\hline
\end{tabular}

${ }^{1}$ Wells were sampled by the U S Geological Survey and ranged from 2 to 32 inches in diamter Generally, the smaller diameter wells are Geological Survey observation wells, those of larger diameter are industrial or abandoned public supply wells Sample-collection procedures were determined mainly by well diameter and depth to water Normally, where the depth to water

was 25 feet or less, a centrifugal pump was used, otherwise a submersible pump was used In places where both centrifugal and submersible pumps were impractical, the samples were bailed The volume of water standing in the well casing was evacuated at least three times, and specific conductance was monitored until stable before sampling was begun All samples were stored and preserved with appropriate chemical reagents as described by the Bureau of Water Supply Laboratory (New York City Department of Environmental Protection, written commun , 1983) Samples were analyzed by the Bureau of Water Supply Laboratory according to methods prescribed by the American Public Health Association (1976) 
Table 10. Selected chemical analyses of ground water sampled from observatıon wells in Kings, Queens, and western Nassau Counties, New York-Contınued $\left[\mu \mathrm{s} / \mathrm{cm}\right.$, microsiemens per centimeter at 25 degrees Celssus, $\mathrm{mg} / \mathrm{L}$, milligrams per liter, $\mu \mathrm{g} / \mathrm{L}$, micrograms per liter, ${ }^{\circ} \mathrm{C}$, degrees Celsius, --, analysis not avallable, $<$, less than, $>$, greater than,

\begin{tabular}{|c|c|c|c|c|c|c|c|c|c|c|c|c|c|c|c|c|}
\hline \multirow{3}{*}{$\begin{array}{cc} \\
\text { Well } \\
\text { number }\end{array}$} & \multirow{3}{*}{\begin{tabular}{|l} 
Latıtude \\
404301
\end{tabular}} & \multirow{2}{*}{$\frac{\text { Longitude }}{735753}$} & \multicolumn{3}{|c|}{$\begin{array}{l}\text { Screened Interval, } \\
\text { In feet above or } \\
\text { below sea level }\end{array}$} & Aquifer & \multirow[t]{2}{*}{$\begin{array}{c}\begin{array}{c}\text { Date } \\
\text { sampled }\end{array} \\
4 / 13 / 81\end{array}$} & \multirow{2}{*}{$\begin{array}{c}\begin{array}{c}\text { Specific } \\
\text { conductance } \\
(\mu \mathrm{s} / \mathrm{cm})\end{array} \\
1,400\end{array}$} & $\underset{\text { (units) }}{\text { pH }}$ & $\begin{array}{c}\text { Field } \\
\text { temperature } \\
\left({ }^{\circ} \mathrm{C}\right)\end{array}$ & $\begin{array}{l}\text { Color } \\
\text { (unit) }\end{array}$ & \multicolumn{2}{|c|}{$\begin{array}{l}\text { Turbidit) } \\
\text { (NTU) }\end{array}$} & \multirow[t]{2}{*}{$\begin{array}{c}\text { Hardness } \\
\left.\begin{array}{c}\text { (mg/L as } \\
\text { CaCO }\end{array}\right) \\
410\end{array}$} & $\begin{array}{l}\text { Calcium, } \\
\text { total (mg/l } \\
\text { as Ca) }\end{array}$ & $\begin{array}{c}\text { Magnesium, } \\
\text { total (mg/h } \\
\text { as } \mathrm{Mg} \text { ) }\end{array}$ \\
\hline & & & -22 & to & -37 & Upglac & & & 67 & 17 & 6 & 1 & 8 & & 100 & 36 \\
\hline & & & & & & & $9 / 20 / 83$ & 1,200 & 66 & 175 & 300 & $>25$ & & 350 & 28 & 18 \\
\hline K2598 & 404230 & 735537 & -37 & to & -48 & Upglac & $3 / 31 / 81$ & 1,030 & 72 & 16 & 23 & & 3 & 400 & 110 & 33 \\
\hline & & & & & & & $7 / 13 / 83$ & 750 & 70 & 16 & 60 & $>20$ & & 240 & 65 & 19 \\
\hline K2610 & 403938 & 735237 & -35 & to & -52 & Upglac & $2 / 12 / 81$ & 4,300 & 69 & 16 & 6 & & 6 & 1,100 & -- & -- \\
\hline & & & & & & & $6 / 8 / 83$ & 4,000 & 65 & 145 & 6 & & 2 & 470 & 180 & 10 \\
\hline K2622 & 404028 & 735354 & -40 & to & -50 & Upglac & $4 / 7 / 81$ & 650 & 69 & 115 & 5 & 1 & 5 & 270 & 29 & 22 \\
\hline & & & & & & & $9 / 15 / 83$ & 1,250 & 71 & 14 & 5 & & 6 & 480 & 140 & 58 \\
\hline K2859 & 403451 & 735856 & -464 & to & -480 & Lloyd & $3 / 27 / 81$ & 500 & 80 & 15 & 18 & 30 & & 40 & 46 & 68 \\
\hline & & & & & & & $7 / 26 / 83$ & 280 & 71 & 16 & 70 & 45 & & 36 & 38 & 15 \\
\hline K3130 & 403748 & 735721 & -207 & to & -258 & Jam & $7 / 28 / 83$ & 1,260 & 73 & 17 & 2 & & 5 & 240 & 120 & 61 \\
\hline K3132 & 403750 & 735717 & -234 & to & -280 & Jam & $7 / 28 / 83$ & 4,890 & 70 & 14 & 65 & & 61 & 14,000 & 280 & 140 \\
\hline K3133 & 404158 & 735658 & -145 & to & -175 & Jam & $3 / 4 / 81$ & 1,700 & 74 & 12 & 6 & & 4 & 460 & 180 & 45 \\
\hline & & & & & & & $6 / 29 / 83$ & 950 & 76 & 15 & 5 & & 6 & 350 & 76 & 32 \\
\hline K3151 & 403921 & 735450 & -20 & to & -70 & Upglac & $9 / 1 / 83$ & 783 & 75 & 15 & 8 & & 4 & 330 & 85 & 35 \\
\hline K3214 & 403813 & 735654 & -26 & to & -49 & Upglac & $7 / 12 / 83$ & 875 & 69 & 17 & 2 & & 2 & 310 & 80 & 37 \\
\hline K3216 & 403755 & 735652 & -24 & to & -47 & Upglac & $7 / 12 / 83$ & 2,600 & 72 & 15 & 8 & & 4 & 1,200 & 140 & 70 \\
\hline K3218 & 403824 & 735656 & -23 & to & -46 & Upglac & $4 / 14 / 81$ & 780 & 74 & 165 & 4 & & 3 & 300 & 65 & 34 \\
\hline & & & & & & & $7 / 12 / 83$ & 800 & 71 & 17 & 7 & 2 & 4 & 290 & 48 & 36 \\
\hline K3242 & 403608 & 735757 & -33 & to & -53 & Upglac & $9 / 20 / 83$ & 573 & 65 & 17 & 5 & & 2 & 190 & 100 & 13 \\
\hline K3245 & 404155 & 735521 & +9 & to & +6 & Upglac & $2 / 25 / 81$ & 1,000 & 69 & -- & 40 & 19 & & 190 & -- & -- \\
\hline $\begin{array}{c}\text { Well } \\
\text { number }\end{array}$ & $\begin{array}{l}\text { Date } \\
\text { sampl }\end{array}$ & led $^{1}$ & $\begin{array}{l}\text { Sodium, } \\
\text { total (mg/l } \\
\text { as Na) }\end{array}$ & $\begin{array}{l}\text { Po } \\
\text { tot }\end{array}$ & $\begin{array}{l}\text { otassium, } \\
\text { otal (mg/L } \\
\text { as K) }\end{array}$ & $\begin{array}{c}\text { Alkalınity } \\
\text { (mg/L as } \\
\left.\mathrm{CaCO}_{3}\right)\end{array}$ & $\begin{array}{c}\text { Sulfate, } \\
\text { dissolved } \\
\left(\mathrm{mg} / \mathrm{L} \text { as } \mathrm{SO}_{4}\right)\end{array}$ & $\begin{array}{c}\text { Chloride, } \\
\text { dissolved } \\
\text { (mg/L as CL) }\end{array}$ & $\begin{array}{l}\text { Flouride, } \\
\text { total (mg/L } \\
\text { as F) }\end{array}$ & $\begin{array}{c}\text { Total } \\
\text { dissolved } \\
\text { solıds (mg/L) }\end{array}$ & $\begin{array}{l}\text { Nitroge } \\
\text { nitrate, } \\
\text { (mg/L a }\end{array}$ & $\begin{array}{l}\text { n, as } \\
\text { total } \\
\text { s N) }\end{array}$ & & $\begin{array}{l}\text { Nitrogen as } \\
\text { mmonta, total } \\
\text { (mg/L as } N)\end{array}$ & $\begin{array}{c}\text { Arsenıc, } \\
\text { total }(\mu \mathrm{g} / \mathrm{L} \\
\text { as As) }\end{array}$ & $\begin{array}{c}\text { Cadmium, } \\
\text { total }(\mu g / L \\
\text { as Cd) }\end{array}$ \\
\hline K2591 & $4 / 13$ & $/ 81$ & 150 & & 12 & 190 & 90 & 250 & 02 & -- & 6 & 7 & & $\begin{array}{ll}0 & 01\end{array}$ & -- & $<10$ \\
\hline & $9 / 20$ & 183 & 29 & & 5 & 150 & 190 & 210 & 4 & 805 & 10 & & & $<03$ & $<50$ & $<10$ \\
\hline K2598 & $3 / 31$ & $/ 81$ & 62 & & 4 & 210 & 130 & 100 & 1 & 508 & 16 & & & 12 & $<1$ & $<10$ \\
\hline & $7 / 13$ & 183 & 62 & & 7 & 44 & 97 & 250 & 3 & 535 & $>10$ & & & 03 & $<50$ & $<10$ \\
\hline K2610 & $2 / 12$ & 181 & -- & & -- & 200 & 98 & 1,300 & -- & 3,320 & 8 & 7 & & 03 & $<50$ & $<10$ \\
\hline & $6 / 8$ & 183 & 340 & & 13 & 230 & -- & 500 & 1 & 2,700 & 9 & 2 & & 11 & $<50$ & $<10$ \\
\hline K2622 & $4 / 7$ & /81 & 20 & & 1 & 96 & 85 & 95 & 2 & -- & 7 & 5 & & $<03$ & - - & $<10$ \\
\hline & $9 / 15$ & 183 & 94 & & 5 & 250 & 82 & 210 & 4 & 864 & 6 & 4 & & $<03$ & $<50$ & $<10$ \\
\hline K2859 & $3 / 27$ & /81 & 70 & & 6 & 52 & 10 & 110 & 4 & 260 & & 3 & & 03 & -- & $<10$ \\
\hline & $7 / 26$ & 183 & 45 & & 5 & 44 & 21 & 52 & -- & 193 & & 24 & & 03 & $<50$ & $<10$ \\
\hline K3130 & $7 / 28$ & 183 & 70 & & 3 & 120 & 78 & 290 & 2 & 866 & 5 & & & $<03$ & $<50$ & $<10$ \\
\hline & $7 / 28$ & 183 & 480 & & 12 & 100 & 180 & 500 & 1 & 3,470 & & 24 & & $<03$ & $<50$ & $<10$ \\
\hline K3133 & $3 / 4$ & /81 & 180 & & 4 & 180 & 130 & 340 & -- & 455 & 2 & 6 & & 21 & $<50$ & $<10$ \\
\hline & $6 / 29$ & 183 & 71 & & 4 & 180 & 1 & 140 & 2 & 707 & 1 & 4 & & 02 & $<50$ & $<10$ \\
\hline K3151 & $9 / 1$ & 183 & 26 & & 5 & 160 & $<50$ & 73 & 2 & -- & 11 & & & -- & $<50$ & $<10$ \\
\hline K3214 & $7 / 12$ & /83 & 55 & & 6 & 120 & -- & 51 & 2 & 612 & $>10$ & & & 03 & $<50$ & $<10$ \\
\hline K3216 & $7 / 12$ & /83 & 160 & & 10 & 110 & -- & 1,100 & 2 & 1,640 & $>10$ & & & 03 & $<50$ & $<10$ \\
\hline K3218 & $4 / 14$ & $/ 81$ & 38 & & 3 & 140 & 57 & 93 & 1 & - & 15 & & & 01 & -- & $<10$ \\
\hline & $7 / 12$ & 183 & 50 & & 5 & 120 & -- & 120 & 2 & 565 & $>10$ & & & 03 & $<50$ & $<10$ \\
\hline K3242 & $9 / 20$ & 183 & 107 & & 4 & 94 & 85 & 40 & 8 & 348 & & 85 & & $<03$ & $<50$ & $<10$ \\
\hline K3245 & $2 / 25$ & $/ 81$ & -- & & -- & 80 & 160 & 160 & -- & 615 & 10 & & & 12 & $<50$ & $<10$ \\
\hline
\end{tabular}


Table 10. Selected chemıcal analyses of ground water sampled from observatıon wells in Kıngs, Queens, and western Nassau Countıes, New York-Contınued $\left[\mu \mathrm{s} / \mathrm{cm}\right.$, microsiemens per centımeter at 25 degrees Celsius, $\mathrm{mg} / \mathrm{L}$, milligrams per liter, $\mu \mathrm{g} / \mathrm{L}$, micrograms per liter, ${ }^{\circ} \mathrm{C}$, degrees Celsius, -- , analysis not available, $<$, less than, $>$, greater than, NTU, Nephelometric turbıdity unit, Neg, negligible, Upglac, upper glacial aquifer, Jameco, Jameco aquifer, Lloyd, Lloyd aquifer, Mag, Magothy aquifer, Rar, Raritan confining unit]

\begin{tabular}{|c|c|c|c|c|c|c|c|c|c|c|c|}
\hline $\begin{array}{c}\text { Well } \\
\text { number }\end{array}$ & $\begin{array}{c}\text { Date } \\
\text { sampled }\end{array}$ & $\begin{array}{c}\text { Chromium, } \\
\text { total }(\mu \mathrm{g} / \mathrm{L} \\
\text { as Cr) }\end{array}$ & $\begin{array}{l}\text { Copper, } \\
\text { total }(\mu \mathrm{g} / \mathrm{L} \\
\text { as Cu) }\end{array}$ & $\begin{array}{c}\text { Iron, } \\
\text { total }(\mu \mathrm{g} / \mathrm{L} \\
\text { as } \mathrm{Fe})\end{array}$ & $\begin{array}{l}\text { Lead, } \\
\text { total }(\mu \mathrm{g} / \mathrm{L} \\
\text { as } \mathrm{Pb})\end{array}$ & $\begin{array}{l}\text { Manganese, } \\
\text { total }(\mu g / L \\
\text { as } M n)\end{array}$ & $\begin{array}{c}\text { Mercury, } \\
\text { total }(\mu \mathrm{g} / \mathrm{L} \\
\text { as } \mathrm{Hg})\end{array}$ & $\begin{array}{l}\text { Selenium, } \\
\text { total }(\mu \mathrm{g} / \mathrm{L} \\
\text { as } \mathrm{Se})\end{array}$ & $\begin{array}{c}\text { Silver, } \\
\text { total }(\mu \mathrm{g} / \mathrm{L} \\
\text { as } \mathrm{Ag})\end{array}$ & $\begin{array}{c}\text { Zınc, } \\
\text { total }(\mu \mathrm{g} / \mathrm{L} \\
\text { as } \mathrm{Zn})\end{array}$ & $\begin{array}{c}\text { Linear } \\
\text { alkyl } \\
\text { sulfonate }\end{array}$ \\
\hline K2591 & $4 / 13 / 81$ & 350 & 50 & 6,100 & $<30$ & 1,900 & $<1$ & -- & $<10$ & 30 & neg \\
\hline \multirow[t]{2}{*}{ K2598 } & $3 / 31 / 81$ & 600 & 10 & 60 & $<10$ & 30 & $<1$ & -- & $<10$ & 20 & neg \\
\hline & $7 / 13 / 83$ & 1,600 & 10 & 120 & $<30$ & 40 & $<1$ & $<10$ & $<50$ & 130 & neg \\
\hline \multirow[t]{2}{*}{ K2610 } & $2 / 12 / 81$ & 150 & 20 & 60 & $<10$ & 160 & $<1$ & $<10$ & $<30$ & 60 & neg \\
\hline & $6 / 8 / 83$ & 140 & 90 & 200 & -- & 130 & 2 & $<10$ & -- & 40 & neg \\
\hline K2622 & $4 / 7 / 81$ & $<50$ & 10 & 60 & $<30$ & 20 & $<1$ & -- & $<10$ & 20 & neg \\
\hline \multirow[t]{2}{*}{ K2859 } & $3 / 27 / 81$ & $<50$ & 10 & 1,700 & $<10$ & 50 & $<1$ & -- & $<10$ & 20 & neg \\
\hline & $7 / 26 / 83$ & $<30$ & 30 & -- & $<30$ & 80 & $<1$ & $<10$ & $<50$ & 70 & neg \\
\hline K3130 & $7 / 28 / 83$ & $<30$ & 20 & 60 & $<30$ & 300 & $<1$ & $<10$ & $<50$ & 50 & neg \\
\hline K3132 & $7 / 28 / 83$ & $<30$ & 10 & 4,300 & $<30$ & 2,300 & $<1$ & $<10$ & $<50$ & 30 & neg \\
\hline \multirow[t]{2}{*}{ K3133 } & $3 / 4 / 81$ & 40 & 50 & 180 & $<10$ & 360 & $<1$ & $<10$ & $<30$ & $<10$ & neg \\
\hline & $6 / 29 / 83$ & $<30$ & 20 & 100 & $<30$ & 300 & $<1$ & $<10$ & $<50$ & 80 & neg \\
\hline K3151 & $9 / 1 / 83$ & $<30$ & 10 & 150 & $<30$ & 50 & $<1$ & $<10$ & $<50$ & 50 & neg \\
\hline K3214 & $7 / 12 / 83$ & $<30$ & 10 & 70 & $<30$ & 50 & $<1$ & $<10$ & $<50$ & 100 & neg \\
\hline K3216 & $7 / 12 / 83$ & $<30$ & 10 & 630 & $<30$ & 120 & $<1$ & $<10$ & $<50$ & 120 & neg \\
\hline K3242 & $9 / 20 / 83$ & $<30$ & 630 & 95,000 & $<30$ & 18,000 & -- & $<10$ & $<50$ & 160 & neg \\
\hline K3245 & $2 / 25 / 81$ & $<40$ & 70 & 50,000 & $<10$ & 8,700 & $<1$ & $<10$ & $<30$ & 25,000 & neg \\
\hline
\end{tabular}

${ }^{1}$ Wells were sampled by the U S Geological Survey and ranged from 2 to 32 inches in diamter Generally, the smaller diameter wells are Geological Survey observation wells, those of larger diameter are industrial or abandoned public supply wells Sample-collection procedures were determined mainly by well diameter and depth to water Normally, where the depth to water was 25 feet or less, a centrifugal pump was used, otherwise a submersible pump was used In places where both centrifugal and submersible pumps were impractical, the samples were bailed The volume of water standing in the well casing was evacuated at least three times, and specific conductance was monitored untıl stable before sampling was begun All samples were stored and preserved with appropriate chemical reagents as described by the Bureau of Water Supply Laboratory (New York City Department of Environmental Protection, written commun , 1983) Samples were analyzed by the Bureau of Water Supply Laboratory according to methods prescribed by the American Public Health Association (1976) 


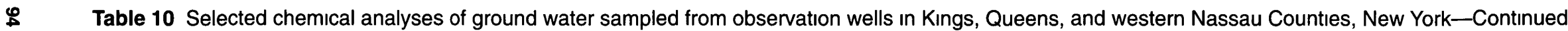
$\left[\mu \mathrm{s} / \mathrm{cm}\right.$, microsiemens per centımeter at 25 degrees Celsius, mg/L, millıgrams per liter, $\mu \mathrm{g} / \mathrm{L}$, micrograms per liter, ${ }^{\circ} \mathrm{C}$, degrees Celsıus, -- , analysis not avallable, $<$, less than, $>$, greater than, NTU, Nephelometric turbidity unit, Neg, negligible, Upglac, upper glacial aquifer, Jameco, Jameco aquifer, Lloyd, Lloyd aquifer, Mag, Magothy aquifer, Rar, Raritan confining unit]

\begin{tabular}{|c|c|c|c|c|c|c|c|c|c|c|c|c|c|c|}
\hline \multirow{2}{*}{ 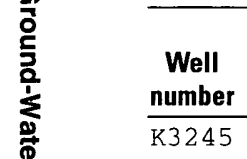 } & \multirow{2}{*}{$\begin{array}{l}\text { Latıtude } \\
404155\end{array}$} & Longitude & \multicolumn{2}{|c|}{$\begin{array}{l}\text { Screened interval, } \\
\text { in feet above or } \\
\text { below sea level }\end{array}$} & \multirow{2}{*}{$\frac{\text { Aquifer }}{\text { Upglac }}$} & \multirow{2}{*}{$\begin{array}{c}\text { Date } \\
\text { sampled }\end{array}$} & \multirow{2}{*}{$\begin{array}{c}\begin{array}{c}\text { Specific } \\
\text { conductance } \\
(\mu \mathrm{s} / \mathrm{cm})\end{array} \\
900\end{array}$} & $\underset{\text { (units) }}{\mathbf{p H}}$ & $\begin{array}{l}\text { Field } \\
\text { temperature } \\
\left({ }^{\circ} \mathrm{C}\right)\end{array}$ & $\begin{array}{l}\text { Color } \\
\text { (unit) }\end{array}$ & $\begin{array}{c}\text { Turbıdity } \\
\text { (NTU) }\end{array}$ & \multirow{2}{*}{$\begin{array}{c}\begin{array}{c}\text { Hardness } \\
(\mathrm{mg} / \mathrm{L} \text { as } \\
\left.\mathrm{CaCO})_{3}\right)\end{array} \\
170\end{array}$} & \multirow{2}{*}{$\begin{array}{c}\begin{array}{c}\text { Calcium, } \\
\text { total }(\mathbf{m g} / \mathbf{L} \\
\text { as } \mathrm{Ca})\end{array} \\
32\end{array}$} & $\begin{array}{c}\text { Magnesıum } \\
\text { total (mg/L } \\
\text { as } \mathrm{Mg})\end{array}$ \\
\hline & & 735521 & +9 & to +6 & & & & 71 & -- & 200 & 22 & & & 21 \\
\hline K3246 & 403902 & 735528 & -1 & to -4 & Upglac & $2 / 10 / 81$ & -- & 62 & 18 & -- & -- & -- & -- & -- \\
\hline & & & & & & $9 / 15 / 83$ & 284 & 57 & 17 & 6 & 7 & 72 & 19 & 72 \\
\hline K3247 & 403605 & 735712 & $-3 t$ & to -6 & Upglac & $8 / 22 / 83$ & 1,300 & 70 & 15 & 85 & -- & 450 & -- & -- \\
\hline K3248 & 403712 & 740016 & -7 & to -10 & Upglac & $2 / 24 / 81$ & 990 & 64 & 15 & 28 & 250 & 400 & -- & 130 \\
\hline & & & & & & $7 / 25 / 83$ & 506 & 67 & 16 & 120 & 41 & 130 & 12 & 29 \\
\hline K3249 & 403623 & 740021 & -11 & to -14 & Upglac & $4 / 22 / 81$ & 800 & 62 & 145 & 75 & 14 & 200 & -- & 54 \\
\hline & & & & & & $7 / 13 / 83$ & 1,110 & 60 & 17 & 12 & 15 & 240 & 30 & 50 \\
\hline K3250 & 403443 & 735755 & $-12 t$ & to -15 & Upglac & $2 / 11 / 81$ & 2,700 & 68 & 16 & 60 & 15 & 500 & $\ldots$ & -- \\
\hline & & & & & & $8 / 30 / 83$ & 2,400 & 68 & 16 & 70 & 75 & 440 & 50 & 82 \\
\hline K3251 & 403520 & 735755 & -10 & to -13 & Upglac & $2 / 11 / 81$ & 470 & 67 & 125 & 5 & 22 & 220 & -- & -- \\
\hline & & & & & & $6 / 30 / 83$ & 450 & 69 & 17 & 27 & 7 & 190 & -- & 98 \\
\hline K3252 & 403702 & 735558 & -11 & to -14 & Upglac & $2 / 11 / 81$ & 580 & 64 & 165 & 27 & 10 & 120 & -- & -- \\
\hline & & & & & & $6 / 15 / 83$ & 575 & 50 & 16 & 35 & 37 & 84 & 23 & 56 \\
\hline K3253 & 403727 & 735908 & -6 & to -9 & Upglac & $8 / 22 / 83$ & 460 & 74 & 16 & 4 & -- & 20 & -- & -- \\
\hline K3254 & 403737 & 735649 & +1 & to -2 & Upglac & $5 / 1 / 81$ & 800 & 66 & 11 & 60 & 7 & 260 & -- & -- \\
\hline & & & & & & $8 / 18 / 83$ & 700 & 64 & 17 & 5 & 44 & 200 & 45 & 21 \\
\hline K3255 & 403827 & 735352 & -2 & to -5 & Upglac & $2 / 11 / 81$ & -- & -- & 17 & -- & -- & -- & -- & -- \\
\hline & & & & & & $6 / 8 / 83$ & 1,150 & -- & 15 & 17 & 45 & 280 & 93 & 14 \\
\hline K3256 & 403949 & 735321 & -1 & to -4 & Upg lac & $2 / 10 / 81$ & 620 & 63 & 185 & 5 & 42 & 180 & -- & -- \\
\hline & & & & & & $6 / 8 / 83$ & 700 & 63 & 18 & 28 & 12 & 200 & 52 & 20 \\
\hline $\begin{array}{c}\text { Well } \\
\text { number }\end{array}$ & $\begin{array}{l}\text { Date } \\
\text { sampl }\end{array}$ & $\operatorname{led}^{1}$ & $\begin{array}{l}\text { Sodium, } \\
\text { total (mg/L } \\
\text { as } \mathrm{Na})\end{array}$ & $\begin{array}{l}\text { Potassium } \\
\text { total (mg/l } \\
\text { as K) }\end{array}$ & $\begin{array}{c}\text { Alkaiınıty } \\
\text { (mg/L as } \\
\left.\mathrm{CaCO}_{3}\right)\end{array}$ & $\begin{array}{c}\text { Sulfate, } \\
\text { dissolved } \\
\left.\text { (mg/L as } \mathrm{SO}_{4}\right) \\
\end{array}$ & $\begin{array}{c}\text { Chloride, } \\
\text { dissolved } \\
\text { (mg/L as } \mathrm{CL}) \\
\end{array}$ & $\begin{array}{l}\text { Flouride, } \\
\text { total (mg/L } \\
\text { as F) }\end{array}$ & $\begin{array}{c}\text { Total } \\
\text { dissolved } \\
\text { solıds (mg/L) }\end{array}$ & $\begin{array}{l}\text { Nitr } \\
\text { nitre } \\
\text { (mg }\end{array}$ & $\begin{array}{l}\text { en, as } \\
\text { total } \\
\text { as N) }\end{array}$ & $\begin{array}{l}\text { Nitrogen as } \\
\text { mmonia, total } \\
\text { (mg/L as N) }\end{array}$ & $\begin{array}{c}\text { Arsenic, } \\
\text { total }(\mu \mathrm{g} / \mathrm{L} \\
\text { as As) } \\
\end{array}$ & $\begin{array}{l}\text { Cadmium, } \\
\text { total }(\mu \mathrm{g} / \mathrm{L} \\
\text { as } \mathrm{Cd})\end{array}$ \\
\hline K3245 & $6 / 29$ & 183 & 120 & 4 & 32 & 100 & 170 & 02 & 686 & & & $0 \quad 06$ & $<50$ & $<10$ \\
\hline K3246 & $2 / 10$ & /81 & -- & -- & -- & -- & -- & -- & -- & & & -- & $<50$ & $<10$ \\
\hline & $9 / 15$ & 183 & 21 & 2 & 30 & 40 & 140 & 3 & 195 & & 9 & $<03$ & $<50$ & $<10$ \\
\hline K3247 & $8 / 22$ & 183 & -- & -- & 46 & 93 & 280 & 2 & -- & & & $<03$ & -- & - \\
\hline K3248 & $2 / 24$ & 181 & 66 & 18 & 100 & 120 & 200 & -. & 610 & & 4 & 06 & $<50$ & $<10$ \\
\hline & $7 / 25$ & 183 & 48 & 4 & 94 & -- & 47 & 4 & 332 & & 8 & 01 & $<50$ & $<10$ \\
\hline K3249 & $4 / 22$ & 181 & 70 & -- & 80 & -- & 200 & 2 & -- & & & 69 & -- & $<10$ \\
\hline & $7 / 13$ & 183 & 120 & 6 & 140 & 59 & 81 & 3 & 758 & & & 01 & $<50$ & 20 \\
\hline K3250 & $2 / 11$ & 181 & -- & -- & 230 & 130 & 690 & -- & 1,620 & & 3 & 39 & $<50$ & $<10$ \\
\hline & $8 / 30$ & 183 & 320 & 75 & 180 & $<50$ & 560 & 2 & -- & & 29 & -- & $<50$ & $<10$ \\
\hline K3251 & $2 / 11$ & 181 & -- & -. & 190 & 20 & 12 & -- & 280 & & 9 & 06 & $<50$ & $<10$ \\
\hline & $6 / 30$ & 183 & 14 & -- & 120 & 35 & 29 & 2 & 346 & & 2 & 02 & $<50$ & $<10$ \\
\hline K3252 & $2 / 11$ & 181 & -- & -- & 96 & 56 & 82 & -- & 338 & & 2 & 75 & $<50$ & $<10$ \\
\hline & $6 / 15$ & 183 & 76 & 6 & 150 & 34 & 38 & 2 & 342 & & 4 & 01 & $<50$ & $<10$ \\
\hline K3253 & $8 / 22$ & 183 & -- & -- & 140 & 28 & 26 & 2 & -- & & & 03 & -- & -- \\
\hline K3254 & $5 / 1$ & /81 & -- & -- & 170 & -- & 100 & $<2$ & -- & & & 12 & -- & $<10$ \\
\hline & $8 / 18$ & 183 & 82 & 6 & 130 & 40 & 82 & 1 & 457 & & & 11 & $<50$ & $<10$ \\
\hline K3255 & $2 / 11$ & /81 & -- & -- & -. & -- & 850 & -- & -- & & & -- & $<50$ & $<10$ \\
\hline & $6 / 8$ & 183 & 82 & 11 & 24 & -- & 270 & 1 & 822 & & & 05 & $<50$ & $<10$ \\
\hline K3256 & $2 / 10$ & $/ 81$ & -- & -- & 46 & 92 & 69 & -- & 369 & & & 15 & $<50$ & $<10$ \\
\hline & $6 / 8$ & 183 & 33 & 5 & 22 & -- & 85 & 1 & 451 & & & 02 & $<50$ & $<10$ \\
\hline
\end{tabular}


Table 10 Selected chemical analyses of ground water sampled from observatıon wells in Kıngs, Queens, and western Nassau Countıes, New York-Contınued $\left[\mu \mathrm{s} / \mathrm{cm}\right.$, microsiemens per centımeter at 25 degrees Celsius, $\mathrm{mg} / \mathrm{L}$, millıgrams per liter, $\mu \mathrm{g} / \mathrm{L}$, micrograms per liter, ${ }^{\circ} \mathrm{C}$, degrees Celsius, --, analysis not avallable, <, less than, $>$, greater than, NTU, Nephelometric turbidity unit, Neg, negligible, Upglac, upper glacial aquifer, Jameco, Jameco aquifer, Lloyd, Lloyd aquifer, Mag, Magothy aquifer, Rar, Raritan confining unit]

\begin{tabular}{|c|c|c|c|c|c|c|c|c|c|c|c|}
\hline $\begin{array}{c}\text { Well } \\
\text { number }\end{array}$ & $\begin{array}{c}\text { Date } \\
\text { sampled }\end{array}$ & $\begin{array}{c}\text { Chromium, } \\
\text { total }(\mu \mathrm{g} / \mathrm{L} \\
\text { as } \mathrm{Cr})\end{array}$ & $\begin{array}{c}\text { Copper, } \\
\text { total }(\mu \mathrm{g} / \mathrm{L} \\
\text { as Cu) }\end{array}$ & $\begin{array}{c}\text { Iron, } \\
\text { total }(\mu \mathrm{g} / \mathrm{L} \\
\text { as } \mathrm{Fe})\end{array}$ & $\begin{array}{c}\text { Lead, } \\
\text { total }(\mu \mathrm{g} / \mathrm{L} \\
\text { as } \mathrm{Pb})\end{array}$ & $\begin{array}{c}\text { Manganese, } \\
\text { total }(\mu \mathrm{g} / \mathrm{L} \\
\text { as } \mathrm{Mn})\end{array}$ & $\begin{array}{c}\text { Mercury, } \\
\text { total }(\mu \mathrm{g} / \mathrm{L} \\
\text { as } \mathrm{Hg})\end{array}$ & $\begin{array}{c}\text { Selenium, } \\
\text { total }(\mu \mathrm{g} / \mathrm{L} \\
\text { as } \mathrm{Se})\end{array}$ & $\begin{array}{c}\text { Silver, } \\
\text { total }(\mu \mathrm{g} / \mathbf{L} \\
\text { as Ag) }\end{array}$ & $\begin{array}{c}Z \text { Inc, } \\
\text { total }(\mu \mathrm{g} / \mathrm{L} \\
\text { as } \mathrm{Zn})\end{array}$ & $\begin{array}{l}\text { Linear } \\
\text { alkyl } \\
\text { sulfonate }\end{array}$ \\
\hline K3245 & $6 / 29 / 83$ & $<30$ & 600 & 80,000 & 360 & 3,400 & $<1$ & $<10$ & $<50$ & 26,000 & neg \\
\hline \multirow[t]{2}{*}{ K3246 } & $2 / 10 / 81$ & $<40$ & 10 & 600 & $<10$ & 170 & $<1$ & $<10$ & $<30$ & 1,400 & neg \\
\hline & $9 / 15 / 83$ & $<30$ & 10 & 5,900 & $<30$ & 200 & -- & $<10$ & $<50$ & 1,500 & neg \\
\hline K3247 & $8 / 22 / 83$ & -- & -- & -- & $<30$ & -- & $<1$ & -- & -- & -- & neg \\
\hline \multirow[t]{2}{*}{ K3248 } & $2 / 24 / 81$ & 50 & 2,500 & 56,000 & $<10$ & 5,300 & $<1$ & $<10$ & $<30$ & 14,000 & neg \\
\hline & $7 / 25 / 83$ & $<30$ & 30 & 12,000 & $<30$ & 250 & $<1$ & $<10$ & $<50$ & 3,500 & neg \\
\hline \multirow[t]{2}{*}{ K3249 } & $4 / 22 / 81$ & $<50$ & 650 & 56,000 & $<30$ & 3,800 & -- & -- & $<10$ & 110,000 & neg \\
\hline & $7 / 13 / 83$ & 60 & 1,400 & 87,000 & 200 & 1,300 & $<1$ & $<10$ & $<50$ & 38,000 & neg \\
\hline \multirow[t]{2}{*}{ K3250 } & $2 / 11 / 81$ & $<40$ & 10 & 6,700 & $<10$ & 1,300 & $<1$ & $<10$ & $<30$ & 730 & neg \\
\hline & $8 / 30 / 83$ & $<30$ & 10 & 18,000 & 30 & 1,000 & $<1$ & $<10$ & $<50$ & 900 & neg \\
\hline \multirow[t]{2}{*}{ K3251 } & $2 / 11 / 81$ & $<40$ & 20 & 2,100 & $<10$ & 400 & $<1$ & $<10$ & $<30$ & 1,400 & neg \\
\hline & $6 / 30 / 83$ & $<30$ & 20 & 950 & $<30$ & 80 & $<1$ & $<10$ & $<50$ & 850 & neg \\
\hline \multirow[t]{2}{*}{ K3252 } & $2 / 11 / 81$ & $<40$ & 10 & 2,700 & $<10$ & 480 & $<1$ & $<10$ & $<30$ & 1,000 & neg \\
\hline & $6 / 15 / 83$ & $<30$ & 40 & 440 & $<30$ & 330 & $<1$ & $<10$ & $<50$ & 200 & neg \\
\hline K3253 & $8 / 22 / 83$ & -- & -- & -- & $<30$ & -- & $<1$ & -- & -- & -- & neg \\
\hline \multirow[t]{2}{*}{ K3254 } & $5 / 1 / 81$ & $<50$ & 90 & 24,000 & $<30$ & -- & -- & -- & -- & -- & neg \\
\hline & $8 / 18 / 83$ & $<30$ & 30 & 3,400 & $<30$ & 60 & 54 & $<10$ & $<50$ & 3,200 & neg \\
\hline \multirow[t]{2}{*}{ K3255 } & $2 / 11 / 81$ & $<40$ & 10 & 2,100 & $<10$ & 50 & $<1$ & $<10$ & $<30$ & 1,400 & neg \\
\hline & $6 / 8 / 83$ & $<30$ & 40 & 560 & $<30$ & 30 & $<1$ & $<10$ & $<50$ & 170 & neg \\
\hline \multirow[t]{2}{*}{ K3256 } & $2 / 10 / 81$ & $<40$ & 10 & 12,000 & $<10$ & 160 & $<1$ & $<10$ & $<30$ & 2,500 & neg \\
\hline & $6 / 8 / 83$ & $<30$ & 30 & 2,100 & $<30$ & 100 & $<1$ & $<10$ & $<50$ & 1,300 & neg \\
\hline
\end{tabular}

${ }^{1}$ Wells were sampled by the U S Geological Survey and ranged from 2 to 32 inches in diamter Generally, the smaller diameter wells are Geological Survey observation wells, those of larger diameter are industrial or abandoned public supply wells Sample-collection procedures were determined mainly by well diameter and depth to water Normally, where the depth to water was 25 feet or less, a centrifugal pump was used, otherwise a submersible pump was used In places where both centrifugal and submersible pumps were impractical, the samples were bailed The volume of water standing in the well casing was evacuated at least three times, and specific conductance was monitored until stable before sampling was begun All samples were stored and preserved with appropriate chemical reagents as described by the Bureau of Water Supply Laboratory (New York City Department of Environmental Protection, written commun , 1983) Samples were analyzed by the Bureau of Water Supply Laboratory accordıng to methods prescribed by the Amencan Public Health Association (1976) 
Table 10 Selected chemıcal analyses of ground water sampled from observatıon wells in Kıngs, Queens, and western Nassau Countıes, New York-Contınued [ $\mu \mathrm{s} / \mathrm{cm}$, microsiemens per centımeter at 25 degrees Celsius, $\mathrm{mg} / \mathrm{L}$, milligrams per liter, $\mu \mathrm{g} / \mathrm{L}$, micrograms per liter, ${ }^{\circ} \mathrm{C}$, degrees Celsius, -- , analysis not avallable, $<$, less than, $>$, greater than,

NTU, Nephelometric turbıdity unit, Neg, neglıgible, Upglac, upper glacial aquifer, Jameco, Jameco aquifer, Lloyd, Lloyd aquifer, Mag, Magothy aquifer, Rar, Rantan confining unt]

\begin{tabular}{|c|c|c|c|c|c|c|c|c|c|c|c|c|c|c|c|c|}
\hline $\begin{array}{c}\text { Well } \\
\text { number }\end{array}$ & Latıtude L & Longitude & $\begin{array}{r}\text { Screen } \\
\text { in fee } \\
\text { below }\end{array}$ & & $\begin{array}{l}\text { nterval, } \\
\text { ove or } \\
\text { level }\end{array}$ & Aquifer & $\begin{array}{c}\text { Date } \\
\text { sampled }\end{array}$ & & $\begin{array}{c}\text { Specific } \\
\text { onductance } \\
(\mu \mathrm{s} / \mathrm{cm})\end{array}$ & $\begin{array}{c}\mathrm{pH} \\
\text { (units) }\end{array}$ & $\begin{array}{c}\text { Field } \\
\text { temperature } \\
\left({ }^{\circ} \mathrm{C}\right) \\
\end{array}$ & $\begin{array}{l}\text { Color } \\
\text { (unit) }\end{array}$ & $\begin{array}{c}\text { Turbıdıty } \\
\text { (NTU) }\end{array}$ & $\begin{array}{c}\text { Hardness } \\
(\mathrm{mg} / \mathrm{L} \text { as } \\
\left.\mathrm{CaCO}_{3}\right)\end{array}$ & $\begin{array}{c}\text { Calcium, } \\
\text { total (mg/L } \\
\text { as Ca) }\end{array}$ & $\begin{array}{c}\text { Magnesium, } \\
\text { total (mg/L } \\
\text { as } \mathrm{Mg})\end{array}$ \\
\hline \multirow{2}{*}{ K3257 } & 404017 & 735445 & +3 & to & 0 & Upglac & $3 / 20 / 8$ & & 1,400 & 59 & 14 & 60 & 35 & 460 & 73 & 66 \\
\hline & & & & & & & $7 / 19 / 8$ & & 707 & 65 & 16 & 44 & $>20$ & 300 & 80 & 32 \\
\hline \multirow[t]{2}{*}{ K3260 } & 404325 & 735635 & -7 & to & -10 & Upglac & $2 / 12 / 8$ & & 2,000 & 68 & 185 & 6 & 27 & 540 & -- & -- \\
\hline & & & & & & & $7 / 12 / 8$ & & 1,600 & 65 & 16 & -- & 80 & 490 & 110 & 50 \\
\hline \multirow[t]{2}{*}{ K3267 } & 403709 & 735841 & -10 & to & -14 & Upglac & $4 / 23 / 8$ & & 400 & 66 & 13 & 5 & 4 & 170 & 16 & 40 \\
\hline & & & & & & & $7 / 19 / 8$ & & 388 & 66 & 16 & 2 & 2 & 170 & 18 & 27 \\
\hline K3271 & 404025 & 735151 & -9 & to & -12 & Upglac & $6 / 21 / 8$ & & 1,220 & 71 & 15 & -- & 65 & 330 & 120 & 18 \\
\hline K3273 & 403817 & 735801 & -3 & to & -6 & Upglac & $9 / 15 / 8$ & & 760 & 64 & 17 & 15 & 16 & 72 & -- & -- \\
\hline K3275 & 403737 & 740117 & -6 & to & -9 & Upglac & $8 / 3 / 8$ & & 861 & 73 & 17 & $>30$ & $>25$ & 380 & 200 & 38 \\
\hline K3276 & 404135 & 735840 & -13 & to & -16 & Upglac & $7 / 25 / 8$ & & 241 & 75 & 13 & 90 & 37 & 100 & 30 & 73 \\
\hline \multirow[t]{2}{*}{ Q 273} & 404257 & 734937 & -281 & to & -411 & Lloyd & $4 / 8 / 8$ & & 160 & 70 & -- & 120 & 50 & 72 & 16 & 80 \\
\hline & & & & & & & $7 / 14 / 8$ & & 133 & 69 & 14 & 14 & 47 & 64 & 13 & 67 \\
\hline Q 277 & 404519 & 734438 & -101 & to & -131 & Mag & $10 / 6 / 8$ & & 144 & 67 & 20 & 75 & 18 & 50 & 12 & 32 \\
\hline Q 287 & 403624 & 734916 & & to & -712 & Lloyd & $7 / 20 / 8$ & & 400 & 65 & 18 & 1 & 32 & 36 & 55 & 28 \\
\hline \multirow{2}{*}{ Q 470} & 404541 & 734526 & -333 & to & -361 & Lloyd & $4 / 20 / 8$ & & 100 & 63 & 13 & 8 & $>20$ & 38 & 82 & 43 \\
\hline & & & & & & & $8 / 31 / 8$ & & 90 & 64 & 14 & 27 & 25 & 16 & 71 & 25 \\
\hline Q 471 & 404541 & 734526 & & to & -98 & Mag & $2 / 19 / 8$ & & 63 & 68 & 125 & 30 & 18 & 40 & -- & -- \\
\hline Q1071 & & & & & & & $9 / 12 / 8$ & & 247 & 65 & 17 & -- & -- & 36 & 83 & 25 \\
\hline $\begin{array}{c}\text { Well } \\
\text { number }\end{array}$ & \multicolumn{2}{|c|}{$\begin{array}{c}\text { Date } \\
\text { sampled }^{1}\end{array}$} & $\begin{array}{c}\text { Sodium, } \\
\text { total (mg// } \\
\text { as } \mathrm{Na} \text { ) }\end{array}$ & & $\begin{array}{l}\text { otassium, } \\
\text { otal (mg/L } \\
\text { as K) }\end{array}$ & $\begin{array}{c}\text { Alkalınity } \\
\text { (mg/L as } \\
\text { CaCO })\end{array}$ & $\begin{array}{r}\text { Sulfate } \\
\text { dissolve } \\
\text { (mg/L as S }\end{array}$ & & $\begin{array}{c}\text { Chloride, } \\
\text { dissolved } \\
\text { (mg/L as CL) }\end{array}$ & $\begin{array}{l}\text { Flouride, } \\
\text { total (mg/L } \\
\text { as F) }\end{array}$ & $\begin{array}{c}\text { Total } \\
\text { dissolved } \\
\text { solids (mg/L) }\end{array}$ & $\begin{array}{l}\text { Nitroge } \\
\text { nitrate, } \\
\text { (mg/L a }\end{array}$ & $\begin{array}{l}\text { n, as } \\
\text { total } \\
\text { is N) }\end{array}$ & $\begin{array}{l}\text { Nitrogen as } \\
\text { mmonia, total } \\
\text { (mg/L as } N \text { ) }\end{array}$ & $\begin{array}{c}\text { Arsenic, } \\
\text { total }(\mu \mathrm{g} / \mathrm{L} \\
\text { as As) }\end{array}$ & $\begin{array}{c}\text { Cadmium, } \\
\text { total }(\mu \mathrm{g} / \mathrm{L} \\
\text { as Cd) }\end{array}$ \\
\hline \multirow[t]{2}{*}{ K3257 } & $3 / 20 /$ & 181 & 41 & & 6 & 120 & 210 & & 230 & 03 & 872 & 12 & & 003 & -- & $<10$ \\
\hline & $7 / 19 /$ & 183 & 29 & & 6 & 100 & 200 & & 31 & 5 & 499 & 16 & & 04 & $<50$ & $<10$ \\
\hline \multirow[t]{2}{*}{ K3260 } & $2 / 12 /$ & /81 & -- & & -- & 250 & 190 & & 380 & -- & 1,300 & 9 & 7 & 06 & $<50$ & $<10$ \\
\hline & $7 / 12 /$ & /83 & 140 & & 10 & 210 & -- & & 360 & 2 & 1,170 & $>10$ & & 01 & $<50$ & 130 \\
\hline \multirow[t]{2}{*}{ K3267 } & $4 / 23 /$ & /81 & 6 & 5 & -- & 100 & -- & & 13 & 1 & -- & 12 & & 14 & -- & $<10$ \\
\hline & $7 / 19 /$ & 183 & 7 & 4 & 2 & 100 & 9 & 2 & 16 & 3 & 266 & 14 & & 01 & $<50$ & $<10$ \\
\hline K3271 & $6 / 21 /$ & 183 & 120 & & 11 & 260 & 100 & & 170 & 3 & 841 & -- & & 03 & $<50$ & $<10$ \\
\hline K3272 & $8 / 30 /$ & 183 & 50 & & 4 & 40 & 73 & & 71 & 3 & 370 & 13 & & $<02$ & $<50$ & $<10$ \\
\hline K3273 & $9 / 15 /$ & /83 & -- & & -- & 30 & 58 & & 140 & 3 & 532 & 8 & 9 & $<03$ & $<50$ & 20 \\
\hline K3275 & $8 / 3 /$ & 183 & 38 & & 8 & 860 & 120 & & 15 & 2 & 562 & $>10$ & & $<03$ & $<50$ & $<10$ \\
\hline K3276 & $7 / 25 /$ & /83 & 8 & 4 & 2 & 100 & -- & & 50 & 9 & 158 & 3 & 5 & 03 & $<50$ & $<10$ \\
\hline \multirow[t]{2}{*}{ Q 273} & $4 / 8 /$ & /81 & 4 & 6 & 1 & 74 & 0 & 0 & 80 & 2 & -- & 1 & 0 & 30 & -- & $<10$ \\
\hline & $7 / 14 /$ & $/ 83$ & 3 & 9 & 1 & 62 & 2 & 7 & 60 & 3 & 99 & & 12 & 01 & $<50$ & $<10$ \\
\hline Q 277 & $10 / 6 /$ & 183 & 92 & 2 & 3 & 40 & 15 & & 17 & 5 & 92 & -- & & $<03$ & $<50$ & $<10$ \\
\hline Q 287 & $7 / 20 /$ & 183 & 64 & & 5 & 30 & -- & & 100 & 3 & 265 & & 72 & 04 & $<50$ & $<10$ \\
\hline \multirow[t]{2}{*}{ Q 471} & $2 / 19 /$ & /81 & -- & & -- & 22 & 4 & 0 & 16 & -- & 45 & 1 & 0 & 20 & $<50$ & $<10$ \\
\hline & $7 / 11 /$ & 183 & 38 & 8 & 06 & 18 & -- & & 60 & 2 & 39 & 1 & 6 & 03 & $<50$ & $<10$ \\
\hline \multirow[t]{2}{*}{ Q1071 } & $4 / 29 /$ & /81 & -- & & -- & 22 & -- & & 57 & 1 & -- & & 60 & 54 & -- & $<10$ \\
\hline & $9 / 12 /$ & 183 & 44 & & 12 & 24 & & & 58 & 2 & 174 & -- & & -- & $<50$ & $<10$ \\
\hline
\end{tabular}


Table 10. Selected chemıcal analyses of ground water sampled from observatıon wells in Kıngs, Queens, and western Nassau Countıes, New York-Contınued $\left[\mu \mathrm{s} / \mathrm{cm}\right.$, microsiemens per centımeter at 25 degrees Celsius, $\mathrm{mg} / \mathrm{L}$, milligrams per liter, $\mu \mathrm{g} / \mathrm{L}$, micrograms per liter, ${ }^{\circ} \mathrm{C}$, degrees Celsius, $\cdots$, analysis not avallable, $<$, less than, $>$, greater than, NTU, Nephelometric turbıdity unit, Neg, negligible, Upglac, upper glacial aquifer, Jameco, Jameco aquifer, Lloyd, Lloyd aquifer, Mag, Magothy aquifer, Rar, Raritan confining unit]

\begin{tabular}{|c|c|c|c|c|c|c|c|c|c|c|c|}
\hline $\begin{array}{c}\text { Well } \\
\text { number }\end{array}$ & $\begin{array}{l}\text { Date } \\
\text { sampled' }\end{array}$ & $\begin{array}{c}\text { Chromium, } \\
\text { total }(\mu \mathrm{g} / \mathrm{L} \\
\text { as } \mathrm{Cr})\end{array}$ & $\begin{array}{l}\text { Copper, } \\
\text { total }(\mu \mathrm{g} / \mathrm{L} \\
\text { as Cu) }\end{array}$ & $\begin{array}{c}\text { Iron, } \\
\text { total }(\mu \mathrm{g} / \mathrm{L} \\
\text { as } \mathrm{Fe})\end{array}$ & $\begin{array}{c}\text { Lead, } \\
\text { total }(\mu \mathrm{g} / \mathrm{L} \\
\text { as } \mathrm{Pb})\end{array}$ & $\begin{array}{l}\text { Manganese, } \\
\text { total }(\mu g / L \\
\text { as } M n)\end{array}$ & $\begin{array}{c}\text { Mercury, } \\
\text { total }(\mu g / L \\
\text { as } \mathrm{Hg})\end{array}$ & $\begin{array}{c}\text { Selenium, } \\
\text { total }(\mu \mathrm{g} / \mathrm{L} \\
\text { as } \mathrm{Se})\end{array}$ & $\begin{array}{c}\text { Silver, } \\
\text { total }(\mu g / L \\
\text { as } A g)\end{array}$ & $\begin{array}{c}\text { Zinc, } \\
\text { total }(\mu \mathrm{g} / \mathrm{L} \\
\text { as } Z \mathrm{n})\end{array}$ & $\begin{array}{l}\text { Linear } \\
\text { alkyl } \\
\text { sulfonate }\end{array}$ \\
\hline K3257 & $3 / 20 / 81$ & $<50$ & 360 & 46,000 & 3,000 & 3,800 & $<1$ & -- & $<20$ & 70,000 & neg \\
\hline \multirow[t]{2}{*}{ K3260 } & $2 / 12 / 81$ & $<40$ & 20 & 1,000 & $<10$ & 60 & $<1$ & $<10$ & $<30$ & 1,400 & neg \\
\hline & $7 / 12 / 83$ & $<30$ & 1,200 & 76,000 & 380 & 450 & $<1$ & $<10$ & $<50$ & 12,000 & neg \\
\hline \multirow[t]{2}{*}{ K3267 } & $4 / 23 / 81$ & $<50$ & 30 & 150 & $<30$ & 30 & -- & -- & $<10$ & 1,600 & neg \\
\hline & $7 / 19 / 83$ & $<30$ & 10 & 70 & $<30$ & 10 & $<1$ & $<10$ & $<50$ & 460 & neg \\
\hline K3271 & $6 / 21 / 83$ & $<30$ & 370 & 13,000 & 650 & 1,700 & 1 & $<10$ & $<50$ & 5,500 & neg \\
\hline K3273 & $9 / 15 / 83$ & $<30$ & 10 & 1,600 & $<30$ & 230 & -- & $<10$ & $<50$ & 8,800 & neg \\
\hline K3275 & $8 / 3 / 83$ & 100 & 3,300 & 60,000 & 1,200 & 5,400 & $<1$ & $<10$ & $<50$ & 73,000 & neg \\
\hline K3276 & $7 / 25 / 83$ & $<30$ & 2,300 & 10,000 & 300 & 150 & $<1$ & $<10$ & $<50$ & 4,500 & neg \\
\hline \multirow[t]{2}{*}{ Q 273} & $4 / 8 / 81$ & $<50$ & 10 & 4,000 & $<30$ & 400 & $<1$ & -- & $<10$ & 20 & neg \\
\hline & $7 / 14 / 83$ & $<30$ & 10 & 5,500 & $<30$ & 400 & $<1$ & $<10$ & $<50$ & 20 & neg \\
\hline Q 277 & $10 / 6 / 83$ & $<30$ & 30 & 1,300 & $<30$ & 140 & $<1$ & $<10$ & $<50$ & 100 & neg \\
\hline Q 287 & $7 / 20 / 83$ & $<30$ & 10 & 28,000 & 150 & 1,400 & $<1$ & $<10$ & $<50$ & 60 & neg \\
\hline \multirow[t]{2}{*}{ Q 470} & $4 / 20 / 81$ & $<50$ & 640 & 70,000 & $<30$ & 130 & -- & -- & $<10$ & -- & neg \\
\hline & $8 / 31 / 83$ & $<30$ & 80 & 29,000 & 460 & 30 & $<1$ & $<10$ & $<50$ & 3,000 & neg \\
\hline Q 471 & $2 / 19 / 81$ & $<40$ & 20 & 790 & $<10$ & 10 & $<1$ & $<10$ & $<30$ & 120 & neg \\
\hline \multirow[t]{2}{*}{ Q1071 } & $4 / 29 / 81$ & $<50$ & 10 & 11,000 & $<30$ & 350 & -- & -- & -- & 20 & neg \\
\hline & $9 / 12 / 83$ & $<30$ & 10 & 11,000 & $<30$ & 340 & -- & $<10$ & $<50$ & 30 & neg \\
\hline
\end{tabular}

${ }^{1}$ Wells were sampled by the U S Geological Survey and ranged from 2 to 32 inches in diamter Generally, the smaller diameter wells are Geological Survey observatıon wells, those of larger diameter are industral or abandoned public supply wells Sample-collection procedures were determined mainly by well diameter and depth to water Normally, where the depth to water was 25 feet or less, a centrifugal pump was used, otherwise a submersible pump was used In places where both centrifugal and submersible pumps were impractical, the samples were balled The volume of water standing in the well casıng was evacuated at least three tımes, and specific conductance was monitored until stable before sampling was begun All samples were stored and preserved with appropriate chemical reagents as described by the Bureau of Water Supply Laboratory (New York City Department of Environmental Protection, written commun, 1983) Samples were analyzed by the Bureau of Water Supply Laboratory accordıng to methods prescribed by the Amencan Public Health Association (1976) 
Table 10 Selected chemıcal analyses of ground water sampled from observatıon wells in Kıngs, Queens, and western Nassau Countıes, New York-Contınued $\left[\mu \mathrm{s} / \mathrm{cm}\right.$, microsiemens per centımeter at 25 degrees Celsıus, $\mathrm{mg} / \mathrm{L}$, milligrams per liter, $\mu \mathrm{g} / \mathrm{L}$, micrograms per liter, ${ }^{\circ} \mathrm{C}$, degrees Celsius, --, analysis not avallable, <, less than, $>$, greater than, NTU, Nephelometric turbıdity unit, Neg, negligible, Upglac, upper glacial aquifer, Jameco, Jameco aquifer, Lloyd, Lloyd aquifer, Mag, Magothy aquifer, Rar, Raritan confinıng unit]

\begin{tabular}{|c|c|c|c|c|c|c|c|c|c|c|c|c|c|c|}
\hline $\begin{array}{c}\text { Well } \\
\text { number }\end{array}$ & Latıtude & Longitude & $\begin{array}{r}\begin{array}{r}\text { Screene } \\
\text { in feet } \\
\text { below }\end{array} \\
\end{array}$ & $\begin{array}{l}\text { ed interval, } \\
\text { t above or } \\
\text { sea level }\end{array}$ & Aquifer & $\begin{array}{c}\text { Date } \\
\text { sampled }\end{array}$ & $\begin{array}{c}\text { Specific } \\
\text { conductance } \\
(\mu \mathrm{s} / \mathrm{cm})\end{array}$ & $\underset{\text { (units) }}{\mathrm{pH}}$ & $\begin{array}{c}\begin{array}{c}\text { Field } \\
\text { temperature } \\
\left({ }^{\circ} \mathrm{C}\right)\end{array} \\
\end{array}$ & $\begin{array}{l}\text { Color } \\
\text { (unit) }\end{array}$ & $\begin{array}{c}\text { Turbıdıty } \\
\text { (NTU) }\end{array}$ & $\begin{array}{c}\text { Hardness } \\
(\mathrm{mg} / \mathrm{L} \text { as } \\
\left.\mathrm{CaCO}_{3}\right)\end{array}$ & $\begin{array}{c}\text { Calcium, } \\
\text { total (mg/L } \\
\text { as Ca) }\end{array}$ & $\begin{array}{c}\text { Magnesium, } \\
\text { total (mg/L } \\
\text { as } \mathrm{Mg}) \\
\end{array}$ \\
\hline Q1187 & 403958 & 734458 & & to -120 & Jam & $7 / 14 / 83$ & 190 & 63 & 14 & 14 & 54 & 52 & 12 & 52 \\
\hline \multirow[t]{2}{*}{ Q1189 } & 403958 & 734458 & & to -35 & Upglac & $2 / 18 / 81$ & 1,650 & 62 & 14 & 27 & 70 & 470 & -- & -- \\
\hline & & & & & & $6 / 7 / 83$ & 1,570 & 63 & 15 & 30 & 27 & 250 & 91 & 15 \\
\hline Q1237 & 403959 & 734744 & & to -200 & Jam & $10 / 6 / 83$ & 1,270 & 76 & 14 & 8 & 12 & 410 & 150 & 46 \\
\hline \multirow{2}{*}{ Q1241 } & 404436 & 735218 & -209 & to -249 & Lloyd & $3 / 3 / 81$ & 230 & 65 & -- & 170 & $>25$ & 60 & 15 & 54 \\
\hline & & & & & & $6 / 15 / 83$ & 280 & 65 & 16 & 450 & 45 & 54 & 15 & 59 \\
\hline Q1373 & 404656 & 735037 & -144 & to -156 & Lloyd & $9 / 22 / 83$ & 3,300 & 78 & 16 & 25 & 7 & 380 & 90 & 28 \\
\hline Q1506 & 403945 & 734825 & -81 & to -93 & Upglac & $8 / 9 / 83$ & 5,000 & 69 & 15 & -- & 45 & 1,100 & 150 & 150 \\
\hline \multirow[t]{2}{*}{ Q1605 } & 404357 & 735204 & -6 & to -17 & Upglac & $2 / 20 / 81$ & 850 & 70 & 155 & 4 & 10 & 410 & -- & -- \\
\hline & & & & & & $9 / 1 / 83$ & 950 & 71 & -- & 9 & 6 & 430 & 120 & 55 \\
\hline \multirow[t]{2}{*}{ Q1663 } & 404205 & 735218 & -31 & to -41 & Upglac & $2 / 19 / 81$ & 730 & 73 & 90 & 9 & 39 & 370 & -- & -- \\
\hline & & & & & & $8 / 8 / 83$ & 881 & 73 & 14 & 2 & 7 & 440 & 110 & 45 \\
\hline Q1914 & 404418 & 734342 & -112 & to -138 & Mag & $8 / 25 / 83$ & 550 & 59 & 13 & 7 & 12 & 610 & 31 & 17 \\
\hline \multirow[t]{2}{*}{ Q1930 } & 403633 & 734525 & -91 & to -111 & Upglac & $3 / 17 / 81$ & $>8,000$ & 68 & 135 & 90 & $>25$ & 2,800 & 240 & 520 \\
\hline & & & & & & $6 / 23 / 83$ & $>9,000$ & 65 & 15 & 120 & 12 & 3,100 & 320 & 440 \\
\hline Q2289 & 404016 & 735006 & -66 & to -117 & Upglac & $7 / 27 / 83$ & 2,340 & 68 & 15 & 8 & 10 & 750 & 140 & 90 \\
\hline $\mathrm{Q} 2324$ & 403957 & 734950 & & to -69 & Upglac & $2 / 13 / 81$ & 1,030 & 74 & 14 & 5 & 28 & 450 & -- & -- \\
\hline Q2384 & 404022 & 734957 & -92 & to -123 & Upglac & $7 / 27 / 83$ & 2,290 & 74 & 14 & 5 & 3 & 750 & 140 & 90 \\
\hline Q2407 & 404320 & 734748 & -19 & to -45 & Upglac & $9 / 7 / 83$ & 500 & 63 & 135 & 7 & 10 & 190 & 40 & 28 \\
\hline $\begin{array}{l}\text { Well } \\
\text { number }\end{array}$ & $\begin{array}{l}\text { Date } \\
\text { sampl }\end{array}$ & led 1 & $\begin{array}{l}\text { Sodıum, } \\
\text { total (mg/L } \\
\text { as } \mathrm{Na} \text { ) }\end{array}$ & $\begin{array}{c}\text { Potassium, } \\
\text { total (mg/L } \\
\text { as K) }\end{array}$ & $\begin{array}{c}\text { Alkalınıty } \\
\text { (mg/L as } \\
\left.\mathrm{CaCO}_{3}\right)\end{array}$ & $\begin{array}{c}\text { Sulfate, } \\
\text { dissolved } \\
\left.\text { (mg/L as } \mathrm{SO}_{4}\right)\end{array}$ & $\begin{array}{c}\text { Chloride, } \\
\text { dissolved } \\
\text { (mg/L as CL) }\end{array}$ & $\begin{array}{c}\text { Flouride, } \\
\text { total (mg/L } \\
\text { as F) }\end{array}$ & $\begin{array}{c}\text { Total } \\
\text { dissolved } \\
\text { solıds (mg/L) }\end{array}$ & $\begin{array}{l}\text { Nitrogen } \\
\text { nitrate, t } \\
\text { (mg/L as }\end{array}$ & $\begin{array}{l}\text { n, as } \\
\text { total } \\
\text { is N) }\end{array}$ & $\begin{array}{l}\text { Nitrogen as } \\
\text { mmonia, total } \\
\text { (mg/L as } \mathrm{N} \text { ) }\end{array}$ & $\begin{array}{c}\text { Arsenic, } \\
\text { total ( } \mu \mathrm{g} / \mathrm{L} \\
\text { as As) }\end{array}$ & $\begin{array}{c}\text { Cadmium, } \\
\text { total }(\mu \mathrm{g} / \mathrm{L} \\
\text { as Cd) }\end{array}$ \\
\hline Q1187 & $7 / 14 /$ & 183 & 99 & 2 & 36 & 29 & 10 & 02 & 111 & & 79 & 001 & $<50$ & $<10$ \\
\hline \multirow[t]{2}{*}{ Q1189 } & $2 / 18 /$ & 181 & -- & -- & 86 & 52 & 470 & -- & 1,020 & 1 & 0 & 96 & $<50$ & $<10$ \\
\hline & $6 / 7 /$ & 183 & 150 & 11 & 120 & 90 & 340 & 1 & 999 & & -- & 30 & $<50$ & $<10$ \\
\hline Q1237 & $10 / 6 /$ & 183 & 68 & 7 & 90 & 25 & 330 & 4 & 779 & & -- & $<03$ & $<50$ & $<10$ \\
\hline \multirow[t]{2}{*}{ Q1241 } & $3 / 3 /$ & 181 & 22 & 2 & 74 & 18 & 12 & -- & 120 & 1 & 2 & 45 & $<50$ & $<10$ \\
\hline & $6 / 15 /$ & 183 & 21 & 4 & 72 & 34 & 14 & 3 & 148 & 3 & 7 & 01 & $<50$ & $<10$ \\
\hline Q1373 & $9 / 22 /$ & 183 & 520 & 15 & 4 & 70 & 1,200 & 4 & 2,350 & & 14 & $<03$ & $<50$ & $<10$ \\
\hline Q1472 & $9 / 22 /$ & 183 & 15 & 2 & 68 & 41 & 37 & 3 & 227 & $>10$ & & $<03$ & $<50$ & $<10$ \\
\hline Q1506 & $8 / 9 /$ & 183 & 870 & 40 & 550 & 290 & 1,700 & 2 & 3,780 & & 36 & $<03$ & $<50$ & $<10$ \\
\hline \multirow[t]{2}{*}{ Q1605 } & $2 / 20 /$ & /81 & -- & -- & 210 & 95 & 62 & -- & 560 & 12 & & 21 & $<50$ & $<10$ \\
\hline & $9 / 1 /$ & 183 & 16 & 6 & 240 & 49 & 120 & 2 & -- & & 80 & -- & $<50$ & $<10$ \\
\hline \multirow[t]{2}{*}{ Q1663 } & $2 / 19 /$ & 181 & -- & -- & 150 & 97 & 45 & -- & 570 & 10 & & 09 & $<50$ & $<10$ \\
\hline & $8 / 8 /$ & 183 & 20 & 2 & 280 & 98 & 51 & 1 & 588 & $>10$ & & $<03$ & $<10$ & $<10$ \\
\hline Q1914 & $8 / 25 /$ & 183 & 44 & 1 & 170 & 20 & 360 & 2 & -- & 9 & 5 & $<03$ & $<50$ & $<10$ \\
\hline Q1930 & $3 / 17 /$ & $/ 81$ & 5,600 & 120 & 110 & 1.000 & 500 & 2 & 14,000 & & 30 & 15 & -- & -- \\
\hline \multirow[t]{2}{*}{$\mathrm{Q} 2324$} & $2 / 13 /$ & 181 & -- & -- & 210 & 100 & 140 & -- & 750 & 9 & 6 & 06 & $<50$ & $<10$ \\
\hline & $6 / 6 /$ & 183 & 38 & -- & 150 & 100 & 140 & 1 & 672 & 22 & & 09 & -- & $<10$ \\
\hline Q2384 & $7 / 27 /$ & 183 & 200 & 4 & 92 & 120 & 640 & -- & 1,560 & 7 & 8 & 03 & $<50$ & $<10$ \\
\hline Q2407 & $9 / 7 /$ & 183 & 28 & 3 & 80 & 40 & 57 & 2 & 350 & 4 & 8 & $<03$ & $<50$ & $<10$ \\
\hline
\end{tabular}


Table 10 Selected chemıcal analyses of ground water sampled from observatıon wells in Kıngs, Queens, and western Nassau Countıes, New York-Contınued $\left[\mu \mathrm{s} / \mathrm{cm}\right.$, microsiemens per centımeter at 25 degrees Celsius, $\mathrm{mg} / \mathrm{L}$, millıgrams per liter, $\mu \mathrm{g} / \mathrm{L}$, micrograms per liter, ${ }^{\circ} \mathrm{C}$, degrees Celsius, -- , analysis not avallable, $<$, less than, $>$, greater than, NTU, Nephelometric turbidity unit, Neg, neglıgible, Upglac, upper glacıal aquifer, Jameco, Jameco aquifer, Lloyd, Lloyd aquifer, Mag, Magothy aquifer, Rar, Rantan confinıng unit]

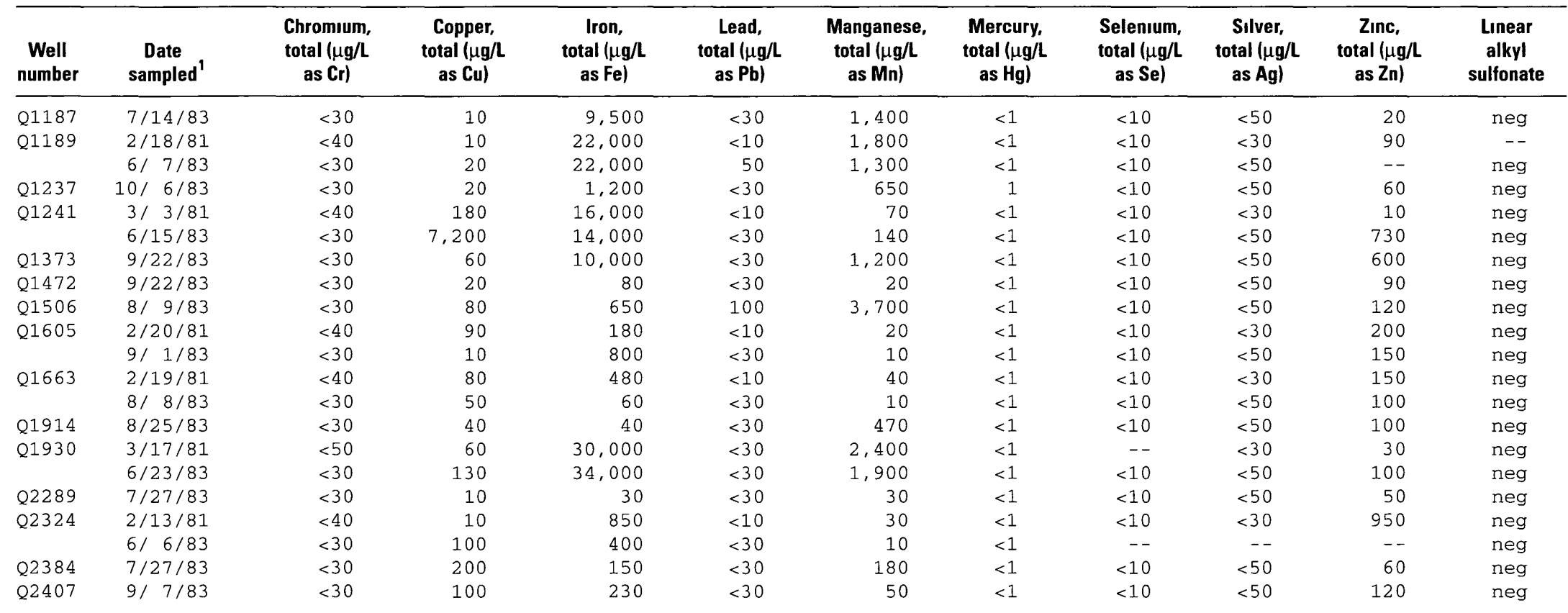

${ }^{1}$ Wells were sampled by the U S Geological Survey and ranged from 2 to 32 inches in diamter Generally, the smaller diameter wells are Geological Survey observation wells, those of larger diameter are industrial or abandoned public supply wells Sample-collection procedures were determined mainly by well diameter and depth to water Normally, where the depth to water was 25 feet or less, a centrifugal pump was used, otherwise a submersible pump was used In places where both centrifugal and submersible pumps were impractical, the samples were banled The volume of water standing in the well casing was evacuated at least three times, and specific conductance was monitored untıl stable before sampling was begun All samples were stored and preserved with appropriate chemical reagents as described by the Bureau of Water Supply Laboratory (New York City Department of Environmental Protection, written commun , 1983) Samples were analyzed by the Bureau of Water Supply Laboratory accordıng to methods prescribed by the American Public Health Association (1976) 
Table 10 Selected chemical analyses of ground water sampled from observation wells in Kings, Queens, and western Nassau Counties, New York-Continued $\left[\mu \mathrm{s} / \mathrm{cm}\right.$, microsiemens per centımeter at 25 degrees Celssus, $\mathrm{mg} / \mathrm{L}$, milligrams per liter, $\mu \mathrm{g} / \mathrm{L}$, micrograms per liter, ${ }^{\circ} \mathrm{C}$, degrees Celsius, $-\cdots$, analysis not avallable, $<$, less than, $>$, greater than, NTU, Nephelometnc turbidity unit, Neg, negligible, Upglac, uppor,

\begin{tabular}{|c|c|c|c|c|c|c|c|c|c|c|c|c|c|c|c|c|}
\hline $\begin{array}{c}\text { Well } \\
\text { number }\end{array}$ & Latıtude & Longitude & $\begin{array}{c}\text { Screene } \\
\text { in feet } \\
\text { below }\end{array}$ & $\begin{array}{l}\text { ed interval, } \\
\text { t above or } \\
\text { sea level }\end{array}$ & Aquifer & $\begin{array}{l}\text { Date } \\
\text { sampled }\end{array}$ & & $\begin{array}{c}\text { Specific } \\
\text { conductance } \\
(\mu \mathrm{s} / \mathrm{cm})\end{array}$ & $\underset{\text { (units) }}{\mathrm{pH}}$ & $\begin{array}{c}\text { Field } \\
\text { temperature } \\
\left({ }^{\circ} \mathrm{C}\right)\end{array}$ & $\begin{array}{l}\text { Color } \\
\text { (unit) }\end{array}$ & $\begin{array}{l}\text { Turb। } \\
\text { (NT }\end{array}$ & $\begin{array}{l}\text { Idity } \\
\text { TU) }\end{array}$ & $\begin{array}{c}\text { Hardness } \\
(\mathrm{mg} / \mathrm{L} \text { as } \\
\left.\mathrm{CaCO}_{3}\right)\end{array}$ & $\begin{array}{l}\text { Calcium, } \\
\text { total (mg/l } \\
\text { as Ca) }\end{array}$ & $\begin{array}{c}\text { Magnesium } \\
\text { total (mg/L } \\
\text { as } \mathrm{Mg})\end{array}$ \\
\hline \multirow[t]{2}{*}{$\overline{Q 2418}$} & 404504 & 735018 & -42 & to -54 & Upglac & $3 / 3 / 8$ & & 2,200 & 68 & 14 & 70 & $>25$ & & 300 & 110 & 42 \\
\hline & & & & & & $8 / 23 / 8$ & & 1,500 & 71 & 13 & $>30$ & 22 & & 300 & 92 & 24 \\
\hline \multirow[t]{2}{*}{ Q2419 } & 404503 & 735019 & -214 & to -264 & Lloyd & $3 / 2 / 8$ & & 150 & 71 & 135 & 100 & 30 & & 62 & 15 & 59 \\
\hline & & & & & & $8 / 10 / 8$ & & 145 & 62 & 14 & 11 & 12 & & 64 & 12 & 56 \\
\hline \multirow[t]{2}{*}{$\mathrm{Q} 2420$} & 404503 & 735020 & -218 & to -268 & Lloyd & $2 / 26 / 8$ & & 155 & 69 & 14 & 150 & 4 & 4 & 70 & 18 & 60 \\
\hline & & & & & & $8 / 23 / 8$ & & 149 & 71 & 14 & $>30$ & $>100$ & & 60 & 14 & 48 \\
\hline Q2426 & 403919 & 734420 & -207 & to -227 & Mag & $8 / 9 / 8$ & & 50 & 61 & 14 & -- & & 8 & 30 & 37 & 10 \\
\hline Q2656 & & & & & & $8 / 4 / 8$ & & 557 & 64 & 14 & -- & & 5 & 370 & 80 & 30 \\
\hline \multirow[t]{2}{*}{ Q2791 } & 404624 & 734835 & +12 & to +4 & Upglac & $5 / 12 / 8$ & & 700 & 70 & 15 & 5 & & 7 & 160 & -- & -- \\
\hline & & & & & & $7 / 28 / 8$ & & 690 & 70 & 15 & 5 & & 3 & 270 & 51 & 28 \\
\hline Q2814 & 404511 & 734852 & -27 & to -36 & Upglac & $6 / 15 / 8$ & & 700 & 62 & 17 & 50 & 4 & 7 & 210 & 48 & 20 \\
\hline \multirow[t]{2}{*}{ Q2978 } & 404703 & 734835 & -2 & to -13 & Upglac & $5 / 18 / 8$ & & 600 & 64 & 13 & 5 & 1 & 4 & 220 & -- & -- \\
\hline & & & & & & $6 / 28 / 8$ & & 480 & 66 & 15 & 13 & 1 & 4 & 220 & 46 & 22 \\
\hline \multirow[t]{2}{*}{ Q2993 } & 404003 & 734622 & & to -56 & Upglac & $2 / 23 / 8$ & & 420 & 60 & 16 & 35 & 16 & & 120 & -- & -- \\
\hline & & & & & & $8 / 30 / 8$ & & 330 & 62 & 15 & 70 & 8 & 7 & 82 & 18 & 83 \\
\hline Q2994 & 403940 & 734436 & & to -56 & Upglac & $6 / 20 / 8$ & & 328 & 62 & 13 & 90 & 45 & & 42 & 67 & 36 \\
\hline Q2995 & 403940 & 734435 & & to -73 & Upglac & $2 / 25 / 8$ & & 85 & 87 & 14 & 90 & 23 & & 22 & -- & -- \\
\hline Q3003 & 404515 & 734231 & -139 & to -179 & Mag & $9 / 7 / 8$ & & 167 & 63 & 19 & 5 & & 2 & 44 & 95 & 55 \\
\hline Q3015 & 404403 & 734858 & -71 & to -111 & Mag & $8 / 8 / 8$ & & 629 & 71 & 16 & 2 & & 3 & 250 & 38 & 28 \\
\hline $\begin{array}{c}\text { Well } \\
\text { number }\end{array}$ & $\begin{array}{r}\text { Dat } \\
\text { sampl }\end{array}$ & led & $\begin{array}{l}\text { Sodium, } \\
\text { total (mg/L } \\
\text { as } \mathrm{Na} \text { ) }\end{array}$ & $\begin{array}{c}\text { Potassium, } \\
\text { total (mg/L } \\
\text { as K) }\end{array}$ & $\begin{array}{c}\text { Alkalınity } \\
\text { (mg/L as } \\
\left.\mathrm{CaCO}_{3}\right)\end{array}$ & $\begin{array}{r}\text { Sulfate } \\
\text { dissolve } \\
\text { (mg/L as }\end{array}$ & $\begin{array}{l}\text { e, } \\
\text { ed } \\
\left.\mathrm{SO}_{4}\right)\end{array}$ & $\begin{array}{c}\text { Chloride, } \\
\text { dissolved } \\
\text { (mg/L as CL) }\end{array}$ & $\begin{array}{c}\text { Flouride, } \\
\text { total (mg/L } \\
\text { as F) }\end{array}$ & $\begin{array}{c}\text { Total } \\
\text { dissolved } \\
\text { solıds (mg/L) }\end{array}$ & $\begin{array}{l}\text { Nitros } \\
\text { nitrat } \\
\text { (mg/l }\end{array}$ & $\begin{array}{l}\text { gen, as } \\
\text { e, total } \\
\text { as N) }\end{array}$ & & $\begin{array}{l}\text { Nitrogen as } \\
\text { mmonia, total } \\
\text { (mg/L as } N \text { ) }\end{array}$ & $\begin{array}{c}\text { Arsenic, } \\
\text { total }(\mu \mathrm{g} / \mathrm{L} \\
\text { as As) }\end{array}$ & $\begin{array}{c}\text { Cadmium, } \\
\text { total }(\mu \mathrm{g} / \mathrm{l} \\
\text { as Cd) }\end{array}$ \\
\hline \multirow[t]{2}{*}{$\mathrm{Q} 2418$} & $3 / 3$ & 181 & 350 & 2 & 230 & 4 & 0 & 550 & -- & 1,300 & & 33 & & 44 & $<50$ & $<10$ \\
\hline & $8 / 23$ & 183 & 230 & 22 & 230 & 6 & 0 & 490 & 4 & -- & & 4 & & 03 & $<50$ & $<10$ \\
\hline \multirow[t]{2}{*}{ Q2419 } & $3 / 2$ & 181 & $\begin{array}{ll}7 & 4\end{array}$ & 1 & 68 & 6 & 3 & 60 & -- & 75 & & 16 & & 30 & $<50$ & $<10$ \\
\hline & $8 / 10$ & 183 & 68 & 2 & 78 & 24 & & 70 & 3 & 98 & & 13 & & $<03$ & $<50$ & $<10$ \\
\hline \multirow[t]{2}{*}{$\mathrm{Q} 2420$} & $2 / 26$ & /81 & 85 & 1 & 68 & 1 & 5 & 15 & -- & 90 & & 08 & & 29 & -- & -- \\
\hline & $8 / 23$ & 183 & 74 & 2 & 72 & 3 & 1 & 80 & 2 & -- & & 2 & & 03 & $<50$ & $<10$ \\
\hline Q2426 & $8 / 9$ & 183 & 38 & 6 & 16 & 24 & & 90 & 1 & -- & & 23 & & $<03$ & $<50$ & $<10$ \\
\hline \multirow[t]{2}{*}{ Q2656 } & $4 / 30$ & $/ 81$ & -- & -- & 270 & -- & & 42 & 2 & -- & & 46 & & 30 & -- & $<10$ \\
\hline & $8 / 4$ & 183 & 13 & 2 & 280 & 45 & & 17 & 1 & 546 & & 86 & & 2 & $<50$ & $<10$ \\
\hline \multirow[t]{2}{*}{ Q2791 } & $5 / 12$ & $/ 81$ & -- & -- & 160 & & & 52 & $<2$ & -- & 1 & 3 & & 03 & -- & -- \\
\hline & $7 / 28$ & 183 & 48 & 2 & 150 & 80 & & 71 & 2 & 477 & & 92 & & 01 & $<50$ & $<10$ \\
\hline Q2814 & $6 / 15$ & 183 & 28 & 4 & 54 & 97 & & 69 & 2 & 388 & & 78 & & 04 & $<50$ & $<10$ \\
\hline \multirow[t]{2}{*}{ Q2978 } & $5 / 18$ & /81 & -- & -- & 70 & -- & & 47 & 1 & -- & & 10 & & 18 & -- & - - \\
\hline & $6 / 28$ & 183 & 19 & 2 & 86 & 100 & & 25 & 3 & 332 & & 20 & & 01 & $<50$ & $<10$ \\
\hline \multirow[t]{2}{*}{ Q2995 } & $2 / 25$ & 181 & -- & -- & 38 & 2 & 4 & 60 & -- & 60 & & 20 & & 40 & $<50$ & $<10$ \\
\hline & $6 / 20$ & 183 & 36 & 2 & 48 & 30 & & 44 & 2 & 191 & & -- & & 01 & $<50$ & $<10$ \\
\hline Q3003 & $9 / 7$ & 183 & 12 & 2 & 34 & 8 & 0 & 26 & 2 & 118 & & 28 & & $<03$ & $<50$ & $<10$ \\
\hline Q3015 & $8 / 8$ & 183 & 19 & 2 & 110 & 80 & & 77 & 1 & 410 & & 82 & & $<03$ & $<50$ & $<10$ \\
\hline
\end{tabular}


Table 10. Selected chemıcal analyses of ground water sampled from observatıon wells in Kıngs, Queens, and western Nassau Countıes, New York-Contınued $\left[\mu \mathrm{s} / \mathrm{cm}\right.$, microsiemens per centımeter at 25 degrees Celsıus, $\mathrm{mg} / \mathrm{L}$, milligrams per liter, $\mu \mathrm{g} / \mathrm{L}$, micrograms per liter, ${ }^{\circ} \mathrm{C}$, degrees Celsıus, --, analysıs not avallable, $<$, less than, $>$, greater than, NTU, Nephelometric turbidity unit, Neg, negligible, Upglac, upper glacial aquifer, Jameco, Jameco aquifer, Lloyd, Lloyd aquifer, Mag, Magothy aquifer, Rar, Raritan confinıng unit]

\begin{tabular}{|c|c|c|c|c|c|c|c|c|c|c|c|}
\hline $\begin{array}{l}\text { Well } \\
\text { number }\end{array}$ & $\begin{array}{c}\text { Date } \\
\text { sampled }\end{array}$ & $\begin{array}{l}\text { Chromıum, } \\
\text { total }(\mu \mathrm{g} / \mathrm{L} \\
\text { as } \mathrm{Cr})\end{array}$ & $\begin{array}{l}\text { Copper, } \\
\text { total }(\mu \mathrm{g} / \mathrm{L} \\
\text { as Cu) }\end{array}$ & $\begin{array}{c}\text { Iron, } \\
\text { total }(\mu \mathrm{g} / \mathrm{L} \\
\text { as } \mathrm{Fe})\end{array}$ & $\begin{array}{l}\text { Lead, } \\
\text { total }(\mu \mathrm{g} / \mathrm{L} \\
\text { as } \mathrm{Pb})\end{array}$ & $\begin{array}{c}\text { Manganese, } \\
\text { total }(\mu \mathrm{g} / \mathrm{L} \\
\text { as } \mathrm{Mn})\end{array}$ & $\begin{array}{c}\text { Mercury, } \\
\text { total }(\mu \mathrm{g} / \mathrm{L} \\
\text { as } \mathrm{Hg})\end{array}$ & $\begin{array}{l}\text { Selenıum, } \\
\text { total }(\mu \mathrm{g} / \mathrm{L} \\
\text { as Se) }\end{array}$ & $\begin{array}{c}\text { Silver, } \\
\text { total }(\mu \mathrm{g} / \mathrm{L} \\
\text { as } \mathrm{Ag})\end{array}$ & $\begin{array}{c}Z \text { Znc, } \\
\text { total }(\mu \mathrm{g} / \mathrm{L} \\
\text { as } \mathrm{Zn})\end{array}$ & $\begin{array}{c}\text { Linear } \\
\text { alkyl } \\
\text { sulfonate }\end{array}$ \\
\hline \multirow[t]{2}{*}{ Q2418 } & $3 / 3 / 81$ & $<40$ & 40 & 32,000 & $<10$ & 1,400 & $<1$ & $<10$ & $<30$ & 30 & neg \\
\hline & $8 / 23 / 83$ & $<30$ & 50 & 22,000 & $<30$ & 880 & $<1$ & $<10$ & $<50$ & 200 & neg \\
\hline \multirow[t]{2}{*}{ Q2419 } & $3 / 2 / 81$ & $<40$ & 70 & 3,600 & $<10$ & 120 & $<1$ & $<10$ & $<30$ & 40 & neg \\
\hline & $8 / 10 / 83$ & $<30$ & 30 & 4,300 & $<30$ & 130 & $<1$ & $<10$ & $<50$ & 20 & neg \\
\hline \multirow[t]{2}{*}{ Q2420 } & $2 / 26 / 81$ & -. & -- & -- & $<10$ & -- & -- & -- & -- & -- & -- \\
\hline & $8 / 23 / 83$ & $<30$ & 50 & 3,500 & $<30$ & 230 & $<1$ & $<10$ & $<50$ & 100 & neg \\
\hline Q2426 & $8 / 9 / 83$ & $<30$ & 10 & 450 & $<30$ & 80 & $<1$ & $<10$ & $<50$ & 20 & neg \\
\hline Q2656 & $8 / 4 / 83$ & $<30$ & 30 & 220 & $<30$ & 80 & $<1$ & $<10$ & $<50$ & 120 & neg \\
\hline \multirow[t]{2}{*}{ Q2791 } & $5 / 12 / 81$ & -- & -- & 90 & $<30$ & -- & -- & -- & -- & -- & neg \\
\hline & $7 / 28 / 83$ & $<30$ & 50 & 280 & $<30$ & 10 & $<1$ & $<10$ & $<50$ & 170 & neg \\
\hline Q2814 & $6 / 15 / 83$ & $<30$ & 130 & 530 & $<30$ & 50 & $<1$ & $<10$ & $<50$ & 70 & neg \\
\hline \multirow{2}{*}{ Q2978 } & $5 / 18 / 81$ & -- & -- & -. & $<30$ & -- & -- & -- & -- & -- & neg \\
\hline & $6 / 28 / 83$ & $<30$ & 60 & 450 & -- & 230 & $<1$ & $<10$ & $<50$ & 130 & neg \\
\hline \multirow[t]{2}{*}{ Q2993 } & $2 / 23 / 81$ & -- & -- & -- & $<10$ & -- & $<1$ & -- & -- & -- & neg \\
\hline & $8 / 30 / 83$ & $<30$ & 70 & 3,800 & $<30$ & 210 & $<1$ & $<10$ & $<50$ & 120 & neg \\
\hline Q2994 & $6 / 20 / 83$ & $<30$ & 160 & 10,000 & $<50$ & 420 & $<1$ & $<10$ & $<50$ & 130 & neg \\
\hline Q2995 & $2 / 25 / 81$ & $<40$ & 50 & 4,200 & $<10$ & 10 & $<1$ & $<10$ & $<30$ & 40 & neg \\
\hline Q3003 & $9 / 7 / 83$ & $<30$ & 50 & 40 & $<30$ & 30 & $<1$ & $<10$ & $<50$ & 100 & neg \\
\hline Q3015 & $8 / 8 / 83$ & $<30$ & 40 & 160 & $<30$ & 10 & $<1$ & $<10$ & $<50$ & 40 & neg \\
\hline
\end{tabular}

${ }^{1}$ Wells were sampled by the U S Geological Survey and ranged from 2 to 32 inches in diamter Generally, the smaller diameter wells are Geological Survey observatıon wells, those of larger diameter are industrial or abandoned public supply wells Sample-collection procedures were determined mainly by well diameter and depth to water Normally, where the depth to water was 25 feet or less, a centrifugal pump was used, otherwise a submersible pump was used In places where both centrifugal and submersible pumps were impractical, the samples were bailed The volume of water standing in the well casing was evacuated at least three times, and specific conductance was monitored until stable before sampling was begun All samples were stored and preserved with appropriate chemical reagents as described by the Bureau of Water Supply Laboratory (New York City Department of Environmental Protection, written commun, 1983) Samples were analyzed by the Bureau of Water Supply Laboratory according to methods prescribed by the Amencan Public Health Association (1976) 
Table 10 Selected chemıcal analyses of ground water sampled from observatıon wells ın Kıngs, Queens, and western Nassau Countıes, New York-Contınued $\left[\mu \mathrm{s} / \mathrm{cm}\right.$, microsiemens per centımeter at 25 degrees Celsıus, $\mathrm{mg} / \mathrm{L}$, milligrams per liter, $\mu \mathrm{g} / \mathrm{L}$, micrograms per liter, ${ }^{\circ} \mathrm{C}$, degrees Celsius, -- , analysıs not avallable, $<$, less than, $>$, greater than, NTU, Nephelometric turbidity unit, Neg, negligible, Upglac, upper glacial aquifer, Jameco, Jameco aquifer, Lloyd, Lloyd aquifer, Mag, Magothy aquifer, Rar, Raritan confining unit]

\begin{tabular}{|c|c|c|c|c|c|c|c|c|c|c|c|c|c|c|}
\hline \multirow{3}{*}{$\frac{\begin{array}{c}\text { Well } \\
\text { number }\end{array}}{03036}$} & \multirow{3}{*}{$\frac{\text { Latıtude }}{404354}$} & Longitude & \multicolumn{2}{|c|}{$\begin{array}{c}\text { Screened interval, } \\
\text { in feet above or } \\
\text { below sea level }\end{array}$} & \multirow{2}{*}{$\frac{\text { Aquifer }}{\text { Lloyd }}$} & \multirow{3}{*}{$\begin{array}{c}\begin{array}{c}\text { Date } \\
\text { sampled }\end{array} \\
3 / 2 / 81 \\
6 / 21 / 83\end{array}$} & \multirow{3}{*}{$\begin{array}{c}\begin{array}{c}\text { Specific } \\
\text { conductance } \\
\text { ( } \boldsymbol{\mu s} / \mathbf{c m})\end{array} \\
195 \\
270\end{array}$} & $\underset{\text { (units) }}{\mathbf{p H}}$ & $\begin{array}{c}\text { Field } \\
\text { temperature } \\
\text { ('C) }\end{array}$ & $\begin{array}{l}\text { Color } \\
\text { (unit) } \\
\end{array}$ & $\begin{array}{c}\text { Turbıdity } \\
\text { (NTU) }\end{array}$ & \multirow[t]{2}{*}{$\begin{array}{c}\begin{array}{c}\text { Hardness } \\
(\mathrm{mg} / \mathrm{L} \text { as } \\
\left.\mathrm{CaCO}_{3}\right)\end{array} \\
36\end{array}$} & $\begin{array}{l}\text { Calcium, } \\
\text { total (mg/l } \\
\text { as Ca) }\end{array}$ & $\begin{array}{c}\text { Magnesium, } \\
\text { total (mg/L } \\
\text { as } \mathrm{Mg})\end{array}$ \\
\hline & & 735200 & -229 & to -249 & & & & 67 & 125 & 150 & 45 & & 90 & 32 \\
\hline & & & & & & & & 69 & 14 & 55 & 60 & 34 & 95 & -- \\
\hline Q3110 & 403845 & 734757 & -296 & to -316 & Jam & $7 / 18 / 83$ & 6,520 & 67 & 15 & 85 & 29 & 1,600 & 400 & 150 \\
\hline Q3112 & 403939 & 734728 & -279 & to -289 & Jam & $8 / 15 / 83$ & 478 & 78 & 14 & 7 & 15 & 160 & 48 & 13 \\
\hline Q3114 & 403932 & 734829 & -7 & to -9 & Upglac & $8 / 18 / 83$ & 950 & 67 & 13 & 30 & 30 & 440 & 94 & 13 \\
\hline Q3115 & 403845 & 734757 & & to -16 & Upglac & $7 / 18 / 83$ & 5,620 & 70 & 18 & 55 & 30 & 800 & 110 & 78 \\
\hline $\begin{array}{l}\text { Q3115 } \\
\text { Q3117 }\end{array}$ & & & & & & $8 / 15 / 83$ & 681 & 62 & 15 & 12 & 33 & 290 & 90 & 12 \\
\hline \multirow[t]{2}{*}{ Q3119 } & 404654 & 734659 & +4 & to +1 & Upglac & $2 / 9 / 81$ & 870 & 59 & 165 & 18 & 85 & 290 & -- & -- \\
\hline & & & & & & $8 / 8 / 83$ & 1,040 & 57 & 155 & 28 & $>25$ & 310 & 65 & 27 \\
\hline \multirow[t]{2}{*}{ Q3121 } & 404631 & 735439 & +6 & to +3 & Upglac & $2 / 27 / 81$ & 1,200 & 72 & 15 & 15 & $>25$ & 400 & -- & 110 \\
\hline & & & & & & $6 / 13 / 83$ & 1,170 & -- & 16 & 100 & 103 & 270 & 120 & 43 \\
\hline \multirow[t]{2}{*}{ Q3123 } & 404421 & 735132 & +1 & to -2 & Upglac & $2 / 9 / 81$ & 1,100 & 71 & 15 & 13 & 25 & 440 & -- & -- \\
\hline & & & & & & $6 / 20 / 83$ & 865 & 74 & 15 & 40 & 16 & 410 & 100 & 34 \\
\hline Q3134 & 404521 & 735051 & -223 & to -233 & Upglac & $9 / 20 / 83$ & 1,850 & 62 & 145 & 3 & 5 & 320 & 50 & 48 \\
\hline Q3150 & 403949 & 734957 & & to -119 & Jam & $6 / 21 / 83$ & $>9,000$ & 70 & 15 & -- & 80 & 5,400 & 400 & 810 \\
\hline N1429 & 403920 & 734107 & -5 & to -8 & Upglac & $9 / 27 / 83$ & 394 & 61 & 20 & 10 & 12 & 250 & 40 & 62 \\
\hline N3864 & 403827 & 734250 & -457 & to -468 & Mag & $10 / 3 / 83$ & 80 & 56 & 15 & 12 & 51 & 10 & 20 & 10 \\
\hline $\begin{array}{l}\text { Well } \\
\text { number }\end{array}$ & $\begin{array}{r}\text { Date } \\
\text { sampl }\end{array}$ & & $\begin{array}{c}\text { Sodium, } \\
\text { total (mg/l } \\
\text { as } \mathrm{Na} \text { ) }\end{array}$ & $\begin{array}{c}\text { Potassium, } \\
\text { total (mg/L } \\
\text { as K) }\end{array}$ & $\begin{array}{c}\text { Alkalinity } \\
\text { (mg/L as } \\
\left.\mathrm{CaCO}_{3}\right)\end{array}$ & $\begin{array}{c}\text { Sulfate, } \\
\text { dissolved } \\
\left(\mathrm{mg}^{\mathrm{L}} \text { as } \mathrm{SO}_{4}\right) \\
\end{array}$ & $\begin{array}{c}\text { Chloride, } \\
\text { dissolved } \\
\text { (mg/L as CL) }\end{array}$ & $\begin{array}{c}\text { Flouride, } \\
\text { total (mg/L } \\
\text { as } \mathrm{F})\end{array}$ & $\begin{array}{c}\text { Total } \\
\text { dissolved } \\
\text { solids (mg/L) } \\
\end{array}$ & $\begin{array}{l}\text { Nitrogen } \\
\text { nitrate, } \\
\text { (mg/L as }\end{array}$ & $\begin{array}{l}\text { n, as } \\
\text { totai } \\
\text { s N) }\end{array}$ & $\begin{array}{l}\text { Nitrogen as } \\
\text { immonia, total } \\
\text { (mg/L as N) }\end{array}$ & $\begin{array}{c}\text { Arsenıc, } \\
\text { total }(\mu \mathrm{g} / \mathrm{L} \\
\text { as As) }\end{array}$ & $\begin{array}{l}\text { Cadmium, } \\
\text { total }(\mu \mathrm{g} / \mathrm{L} \\
\text { as Cd) }\end{array}$ \\
\hline Q3036 & $3 / 2 /$ & /81 & 30 & 2 & 72 & 13 & 10 & -- & 110 & & 08 & 20 & $<50$ & $<10$ \\
\hline & $6 / 21 /$ & 183 & 27 & 3 & 72 & 11 & 16 & 2 & 148 & & - & 02 & $<50$ & $<10$ \\
\hline Q3109 & $8 / 18 /$ & $/ 83$ & 2,800 & 8 & 82 & 350 & 6,400 & 2 & 8,300 & & 4 & 04 & $<50$ & $<10$ \\
\hline Q3110 & $7 / 18 /$ & 183 & 610 & 70 & 98 & 200 & 2,300 & 3 & 4,520 & & 01 & 05 & $<50$ & $<10$ \\
\hline Q3112 & $8 / 15 /$ & 183 & 31 & 4 & 66 & 12 & 110 & 2 & 341 & & - & 1 & $<50$ & $<10$ \\
\hline Q3114 & $8 / 18 /$ & 183 & 52 & 10 & 230 & 180 & 72 & 4 & 644 & & 50 & $<01$ & $<50$ & $<10$ \\
\hline Q3115 & $7 / 18 /$ & /83 & 1,000 & 100 & 330 & -- & 1,800 & -- & 3,900 & & 24 & 06 & $<50$ & 20 \\
\hline Q3117 & $2 / 9 /$ & $/ 81$ & -- & -- & 120 & 96 & 47 & -- & 380 & & 50 & 22 & $<50$ & $<10$ \\
\hline & $8 / 15 /$ & 183 & 29 & 18 & 180 & 40 & 95 & 2 & 490 & & - & 13 & $<50$ & $<10$ \\
\hline Q3119 & $2 / 9 /$ & /81 & -- & -- & 20 & 92 & 160 & -- & 540 & 6 & 0 & 09 & $<50$ & $<10$ \\
\hline & $8 / 8 /$ & 183 & 65 & 4 & 16 & 100 & 240 & 1 & 682 & 8 & 6 & 03 & $<50$ & $<10$ \\
\hline Q3121 & $2 / 27$ & /81 & 64 & 2 & 250 & 14 & 160 & -- & 800 & 17 & & 12 & $<50$ & $<10$ \\
\hline & $6 / 13$ & 183 & 54 & 6 & 140 & 100 & 66 & 2 & 771 & 5 & 8 & 03 & $<50$ & $<10$ \\
\hline Q3123 & $2 / 9 /$ & /81 & -- & -- & 230 & 150 & 79 & -- & 650 & 25 & & 90 & $<50$ & $<10$ \\
\hline & $6 / 20 /$ & 183 & 31 & 2 & 210 & 110 & 73 & 3 & 580 & & -- & 03 & $<50$ & $<10$ \\
\hline N1429 & $9 / 27 /$ & $/ 83$ & 27 & 8 & 54 & 75 & 35 & 3 & 278 & $>10$ & & $<03$ & $<50$ & $<10$ \\
\hline N1627 & $4 / 13$ & /81 & 18 & 7 & 66 & 50 & 30 & 1 & -- & 7 & 2 & 01 & -- & $<10$ \\
\hline & $7 / 21 /$ & 183 & 83 & 6 & 74 & -- & 23 & 3 & 259 & 2 & 1 & 02 & $<50$ & $<10$ \\
\hline N3864 & $10 / 3 /$ & 183 & 88 & 2 & 14 & 55 & 13 & -- & 45 & & 05 & $<03$ & $<50$ & $<10$ \\
\hline
\end{tabular}


Table 10 Selected chemical analyses of ground water sampled from observatıon wells in Kıngs, Queens, and western Nassau Countıes, New York-Contınued $\left[\mu \mathrm{s} / \mathrm{cm}\right.$, microsiemens per centımeter at 25 degrees Celsıus, $\mathrm{mg} / \mathrm{L}$, millıgrams per liter, $\mu \mathrm{g} / \mathrm{L}$, micrograms per liter, ${ }^{\circ} \mathrm{C}$, degrees Celsıus, -- , analysis not avallable, $<$, less than, $>$, greater than, NTU, Nephelometnc turbıdity unit, Neg, negligible, Upglac, upper glacial aquifer, Jameco, Jameco aquifer, Lloyd, Lloyd aquifer, Mag, Magothy aquifer, Rar, Raritan confining unit]

\begin{tabular}{|c|c|c|c|c|c|c|c|c|c|c|c|}
\hline $\begin{array}{l}\text { Well } \\
\text { number }\end{array}$ & $\begin{array}{c}\text { Date } \\
\text { sampled' }\end{array}$ & $\begin{array}{c}\text { Chromium, } \\
\text { total }(\mu \mathrm{g} / \mathrm{L} \\
\text { as Cr) }\end{array}$ & $\begin{array}{l}\text { Copper, } \\
\text { total }(\mu \mathrm{g} / \mathrm{L} \\
\text { as } \mathrm{Cu})\end{array}$ & $\begin{array}{c}\text { Iron, } \\
\text { total }(\mu \mathrm{g} / \mathrm{L} \\
\text { as } \mathrm{Fe})\end{array}$ & $\begin{array}{l}\text { Lead, } \\
\text { total }(\mu g / L \\
\text { as Pb) }\end{array}$ & $\begin{array}{c}\text { Manganese, } \\
\text { total }(\mu \mathrm{g} / \mathrm{L} \\
\text { as } \mathrm{Mn})\end{array}$ & $\begin{array}{c}\text { Mercury, } \\
\text { total }(\mu \mathrm{g} / \mathrm{L} \\
\text { as } \mathrm{Hg})\end{array}$ & $\begin{array}{c}\text { Selenium, } \\
\text { total }(\mu \mathrm{g} / \mathrm{L} \\
\text { as } \mathrm{Se})\end{array}$ & $\begin{array}{c}\text { Silver, } \\
\text { total }(\mu \mathrm{g} / \mathrm{L} \\
\text { as } \mathrm{Ag})\end{array}$ & $\begin{array}{c}\text { Zinc, } \\
\text { total }(\mu \mathrm{g} / \mathrm{L} \\
\text { as } Z n)\end{array}$ & $\begin{array}{l}\text { Linear } \\
\text { alkyl } \\
\text { sulfonate }\end{array}$ \\
\hline Q3036 & $3 / 2 / 81$ & $<40$ & 40 & 17,000 & $<10$ & 150 & $<1$ & $<10$ & $<30$ & 260 & neg \\
\hline Q3109 & $8 / 18 / 83$ & $<30$ & 20 & 32,000 & $<30$ & 30 & $<1$ & $<10$ & $<50$ & 80 & neg \\
\hline Q3110 & $7 / 18 / 83$ & $<30$ & 20 & 14,000 & $<30$ & 2,400 & $<1$ & $<10$ & $<50$ & 40 & neg \\
\hline Q3112 & $8 / 15 / 83$ & $<30$ & 50 & 350 & $<30$ & 170 & $<1$ & $<10$ & $<50$ & 70 & neg \\
\hline Q3114 & $8 / 18 / 83$ & $<30$ & 10 & 4,700 & $<30$ & 20 & $<1$ & $<10$ & $<50$ & 60 & neg \\
\hline Q3115 & $7 / 18 / 83$ & $<30$ & -- & 2,900 & 350 & 270 & $<1$ & $<10$ & $<50$ & 90 & neg \\
\hline \multirow[t]{2}{*}{ Q3117 } & $2 / 9 / 81$ & $<40$ & 130 & 1,400 & $<10$ & 1,600 & $<1$ & $<10$ & $<30$ & 150 & neg \\
\hline & $8 / 15 / 83$ & $<30$ & 90 & 3,400 & 40 & 1,600 & $<1$ & $<10$ & $<50$ & 100 & neg \\
\hline \multirow[t]{2}{*}{ Q3119 } & $2 / 9 / 81$ & $<40$ & 10 & 1,300 & $<10$ & 50 & $<1$ & $<10$ & $<30$ & 1,600 & neg \\
\hline & $8 / 8 / 83$ & $<30$ & 1,800 & 18,000 & 100 & 260 & $<1$ & $<10$ & $<50$ & 5.500 & neg \\
\hline \multirow[t]{2}{*}{ Q3121 } & $2 / 27 / 81$ & $<40$ & 350 & 37,000 & $<10$ & 4,200 & $<1$ & $<10$ & $<30$ & 310 & neg \\
\hline & $6 / 13 / 83$ & $<30$ & 50 & 1,600 & $<30$ & 300 & $<1$ & $<10$ & $<50$ & 190 & neg \\
\hline \multirow[t]{2}{*}{ Q3123 } & $2 / 9 / 81$ & $<40$ & 10 & 2,600 & $<10$ & 120 & $<1$ & $<10$ & $<30$ & 1,000 & neg \\
\hline & $6 / 20 / 83$ & $<30$ & 70 & 1,200 & $<30$ & 100 & $<1$ & $<10$ & $<50$ & 380 & neg \\
\hline Q3134 & $9 / 20 / 83$ & $<30$ & 20 & 120 & $<30$ & 270 & $<1$ & $<10$ & $<50$ & 100 & neg \\
\hline Q3150 & $6 / 21 / 83$ & $<30$ & 70 & 10,000 & $<30$ & 900 & $<1$ & $<10$ & $<50$ & 200 & neg \\
\hline & $7 / 21 / 83$ & $<30$ & 30 & 1,400 & $<30$ & 90 & $<1$ & $<10$ & $<50$ & 120 & neg \\
\hline N3864 & $10 / 3 / 83$ & $<30$ & 30 & 2,800 & $<30$ & 20 & $<1$ & $<10$ & $<50$ & 50 & neg \\
\hline
\end{tabular}

${ }^{1}$ Wells were sampled by the U S Geological Survey and ranged from 2 to 32 inches in diamter Generally, the smaller diameter wells are Geological Survey observatıon wells, those of larger diameter are industrial or abandoned public supply wells Sample-collection procedures were determined mainly by well diameter and depth to water Normally, where the depth to water was 25 feet or less, a centrifugal pump was used, otherwise a submersible pump was used In places where both centrifugal and submersible pumps were impractical, the samples were balled The volume of water standing in the well casing was evacuated at least three umes, and specific conductance was monitored until stable before sampling was begun All samples were stored and preserved with appropriate chemical reagents as described by the Bureau of Water Supply Laboratory (New York City Department of Environmental Protection, written commun , 1983) Samples were analyzed by the Bureau of Water Supply Laboratory according to methods prescribed by the Amencan Public Health Association (1976) 
Table 10 Selected chemıcal analyses of ground water sampled from observation wells in Kings, Queens, and western Nassau Counties, New York-Contınued $\left[\mu \mathrm{s} / \mathrm{cm}\right.$, microsiemens per centımeter at 25 degrees Celsius, $\mathrm{mg} / \mathrm{L}$, milligrams per $1 \mathrm{lter}, \mu \mathrm{g} / \mathrm{L}$, micrograms per liter, ${ }^{\circ} \mathrm{C}$, degrees Celsius,,-- analysis not avallable, $<$, less than, $>$, greater than, NTU, Nephelometric turbidity unit, Neg, negligible, Upglac, upper glacial aquifer, Jameco, Jameco aquifer, Lloyd, Lloyd aquifer, Mag, Magothy aquifer, Rar, Raritan confining unit]

\begin{tabular}{|c|c|c|c|c|c|c|c|c|c|c|c|c|c|c|c|c|c|c|c|c|}
\hline \multirow{2}{*}{$\begin{array}{c}\begin{array}{c}\text { Well } \\
\text { number }\end{array} \\
\text { N3867 }\end{array}$} & \multirow{2}{*}{$\begin{array}{l}\text { Latıtude } \\
403912\end{array}$} & Longitude & \multicolumn{3}{|c|}{$\begin{array}{c}\text { Screened interval, } \\
\text { in feet above or } \\
\text { below sea level }\end{array}$} & Aquifer & \multicolumn{2}{|c|}{$\begin{array}{c}\text { Date } \\
\text { sampled }\end{array}$} & \multicolumn{2}{|c|}{$\begin{array}{c}\text { Specific } \\
\text { conductance } \\
(\mu \mathrm{s} / \mathrm{cm})\end{array}$} & \multicolumn{2}{|c|}{$\begin{array}{c}\mathrm{pH} \\
\text { (units) }\end{array}$} & \multicolumn{2}{|c|}{$\begin{array}{c}\text { Field } \\
\text { temperature } \\
\left({ }^{\circ} \mathrm{C}\right)\end{array}$} & $\begin{array}{l}\text { Color } \\
\text { (unit) }\end{array}$ & \multicolumn{2}{|c|}{$\begin{array}{c}\text { Turbıdity } \\
\text { (NTU) }\end{array}$} & $\begin{array}{c}\text { Hardness } \\
(\mathrm{mg} / \mathrm{L} \text { as } \\
\left.\mathrm{CaCO})_{3}\right)\end{array}$ & \multirow[t]{2}{*}{$\begin{array}{c}\text { Calcium, } \\
\text { total (mg/L } \\
\text { as Ca) }\end{array}$} & $\begin{array}{c}\text { Magnesium } \\
\text { total (mg/L } \\
\text { as } \mathrm{Mg})\end{array}$ \\
\hline & & 734320 & -499 & to & -511 & Mag & $10 / 4 / 8$ & & 51 & & 6 & & 14 & 5 & 12 & 6 & & 8 & & 23 \\
\hline N3932 & 403751 & 734401 & -165 & to & -169 & Jam & $9 / 29 / \varepsilon$ & & 40 & & & 8 & 15 & & 23 & & 3 & 37 & 25 & 080 \\
\hline N4026 & 403713 & 734159 & -145 & to & -149 & Jam & $9 / 28 / \varepsilon$ & & 61 & & & 4 & 15 & & 40 & $>25$ & & 18 & 53 & 11 \\
\hline N4062 & 403621 & 734418 & -129 & to & -134 & Jam & $9 / 27 / \varepsilon$ & & 175 & & & 7 & 15 & & 65 & 75 & & 88 & 85 & 38 \\
\hline N4213 & 403912 & 734320 & -125 & to & -129 & Jam & $10 / 4 / 8$ & & 72 & & & 5 & 15 & & 20 & 4 & 0 & 16 & 32 & 24 \\
\hline N6581 & 403827 & 734250 & -566 & to & -576 & Mag & $10 / 3 / 8$ & & $>8,000$ & & 5 & 9 & 15 & & .000 & 31 & & 5,200 & -- & 96 \\
\hline N6701 & 403517 & 734306 & -811 & to & -821 & Rar & $10 / 5 / 8$ & & 2,600 & & 7 & 2 & 17 & & 360 & $>25$ & & 160 & 20 & 30 \\
\hline N6707 & 403713 & 734159 & -487 & to & -497 & Mag & $9 / 28 / 8$ & & 5,190 & & 6 & 2 & 15 & 5 & 90 & $>25$ & & 1,500 & 100 & 120 \\
\hline N6792 & 403713 & 734159 & -42 & to & -44 & Upglac & $9 / 28 / \varepsilon$ & & 182 & & 7 & 3 & 15 & & 45 & & 2 & 76 & 18 & 35 \\
\hline N7161 & 403856 & 733926 & -654 & to & -658 & Mag & $10 / 4 / 8$ & & 45 & & & 8 & 15 & & 25 & 12 & & 8 & 15 & 02 \\
\hline N8877 & 404730 & 734231 & -59 & to & -64 & Upglac & $9 / 29 / 8$ & & 134 & & 6 & 1 & 14 & 5 & 150 & 2 & 5 & 54 & 9 & 66 \\
\hline $\begin{array}{c}\text { Well } \\
\text { number }\end{array}$ & $\begin{array}{r}\text { Dat } \\
\text { samp }\end{array}$ & te & $\begin{array}{c}\text { Sodium, } \\
\text { total (mg/h } \\
\text { as } \mathrm{Na} \text { ) }\end{array}$ & & $\begin{array}{l}\text { otassium, } \\
\text { otal (mg/L } \\
\text { as K) }\end{array}$ & $\begin{array}{c}\text { Alkalınity } \\
\text { (mg/L as } \\
\left.\mathrm{CaCO}_{3}\right)\end{array}$ & $\begin{array}{r}\text { Sulfate } \\
\text { dissolv } \\
\text { (mg/L as }\end{array}$ & $\begin{array}{l}\text { e, } \\
\left.\mathrm{SO}_{4}\right)\end{array}$ & $\begin{array}{l}\text { Chloride } \\
\text { dissolved } \\
\text { (mg/L as C }\end{array}$ & & $\begin{array}{r}\text { Flou } \\
\text { total } \\
\text { as }\end{array}$ & $\begin{array}{l}\text { uride, } \\
\text { I (mg/L } \\
\text { s F) }\end{array}$ & $\begin{array}{r}T \\
\text { dis } \\
\text { solid }\end{array}$ & $\begin{array}{l}\text { Total } \\
\text { ssolved } \\
\text { ds (mg/L) }\end{array}$ & & $\begin{array}{l}\text { en, as } \\
\text {, total } \\
\text { as N) }\end{array}$ & & $\begin{array}{l}\text { Nitrogen as } \\
\text { Immonia, total } \\
\text { (mg/L as } \mathrm{N} \text { ) }\end{array}$ & $\begin{array}{c}\text { Arsenic, } \\
\text { total }(\mu \mathrm{g} / \mathrm{L} \\
\text { as As) }\end{array}$ & $\begin{array}{c}\text { Cadmium, } \\
\text { total }(\mu \mathrm{g} / \mathrm{L} \\
\text { as Cd) }\end{array}$ \\
\hline N3867 & $10 / 4$ & $/ 83$ & 49 & & 9 & 14 & 8 & 0 & 6 & 0 & $<$ & 2 & & 32 & & 003 & & $<0 \quad 03$ & $<50$ & $<10$ \\
\hline N3932 & $9 / 29$ & $/ 83$ & 41 & & 1 & 14 & -- & & 60 & 0 & & 4 & & -- & & 07 & & $<03$ & $<50$ & $<10$ \\
\hline N4213 & $10 / 4$ & $/ 83$ & 57 & 7 & 8 & 20 & 6 & 5 & 8 & 0 & $<$ & 2 & & 47 & & 07 & & $<03$ & $<50$ & $<10$ \\
\hline N6581 & $10 / 3$ & 183 & 5,100 & & 24 & 96 & 4,000 & & 5,200 & & & 5 & & -- & & 13 & & $<03$ & $<50$ & $<10$ \\
\hline N6701 & $10 / 5$ & 183 & 400 & & 25 & 38 & 45 & & 860 & & & 4 & 1, & 710 & & 14 & & $<03$ & $<50$ & $<10$ \\
\hline N6703 & $10 / 5$ & 183 & 2,600 & & 60 & 22 & 950 & & 5,800 & & & 4 & & 900 & & 25 & & $<03$ & $<50$ & $<10$ \\
\hline N6707 & $9 / 28$ & $/ 83$ & 780 & & 21 & 6 & 230 & & 1,900 & & & 3 & & 650 & & 17 & & $<03$ & $<50$ & $<10$ \\
\hline N6792 & $9 / 28$ & $/ 83$ & 75 & & 2 & 90 & 4 & 5 & 13 & & & 3 & & 134 & & 03 & & $<03$ & $<50$ & $<10$ \\
\hline N7161 & $10 / 4$ & $/ 83$ & 45 & & 6 & 18 & 6 & 5 & 9 & 0 & $<$ & 2 & & -- & & 40 & & 05 & $<50$ & $<10$ \\
\hline N8877 & $9 / 29$ & $1 / 83$ & 55 & & 2 & 28 & -- & & 18 & & & 4 & & -- & & 09 & & $<03$ & $<50$ & $<10$ \\
\hline
\end{tabular}


Table 10. Selected chemıcal analyses of ground water sampled from observatıon wells in Kıngs, Queens, and western Nassau Countıes, New York-Contınued $\left[\mu \mathrm{s} / \mathrm{cm}\right.$, microsiemens per centımeter at 25 degrees Celsıus, $\mathrm{mg} / \mathrm{L}$, milligrams per liter, $\mu \mathrm{g} / \mathrm{L}$, micrograms per liter, ${ }^{\circ} \mathrm{C}$, degrees Celsius, -- , analysıs not avallable, $<$, less than, $>$, greater than, NTU, Nephelometnc turbidity unit, Neg, negligible, Upglac, upper glacial aquifer, Jameco, Jameco aquifer, Lloyd, Lloyd aquifer, Mag, Magothy aquifer, Rar, Raritan confinıng unit]

\begin{tabular}{|c|c|c|c|c|c|c|c|c|c|c|c|}
\hline $\begin{array}{c}\text { Well } \\
\text { number }\end{array}$ & $\begin{array}{l}\text { Date } \\
\text { sampled }{ }^{1}\end{array}$ & $\begin{array}{c}\text { Chromium, } \\
\text { total }(\mu \mathrm{g} / \mathrm{L} \\
\text { as } \mathrm{Cr})\end{array}$ & $\begin{array}{c}\text { Copper, } \\
\text { total }(\mu \mathrm{g} / \mathrm{L} \\
\text { as } \mathrm{Cu})\end{array}$ & $\begin{array}{c}\text { Iron, } \\
\text { total }(\mu \mathrm{g} / \mathrm{L} \\
\text { as } \mathrm{Fe})\end{array}$ & $\begin{array}{c}\text { Lead, } \\
\text { total }(\mu \mathrm{g} / \mathrm{L} \\
\text { as } \mathrm{Pb})\end{array}$ & $\begin{array}{c}\text { Manganese, } \\
\text { total }(\mu \mathrm{g} / \mathrm{L} \\
\text { as } \mathrm{Mn})\end{array}$ & $\begin{array}{c}\text { Mercury, } \\
\text { total }(\mu \mathrm{g} / \mathrm{L} \\
\text { as } \mathrm{Hg})\end{array}$ & $\begin{array}{c}\text { Selenıum, } \\
\text { total }(\mu \mathrm{g} / \mathrm{L} \\
\text { as } \mathrm{Se})\end{array}$ & $\begin{array}{c}\text { Silver, } \\
\text { total }(\mu \mathrm{g} / \mathrm{L} \\
\text { as } \mathbf{A g})\end{array}$ & $\begin{array}{c}\text { Zinc, } \\
\text { total }(\mu \mathrm{g} / \mathrm{L} \\
\text { as } \mathrm{Zn})\end{array}$ & $\begin{array}{l}\text { Linear } \\
\text { alkyl } \\
\text { sulfonate }\end{array}$ \\
\hline N3867 & $10 / 4 / 83$ & $<30$ & 10 & 3,700 & $<30$ & 10 & $<1$ & $<10$ & $<50$ & 50 & neg \\
\hline N3932 & $9 / 29 / 83$ & $<30$ & 40 & 3,300 & $<30$ & 10 & $<1$ & $<10$ & $<50$ & 70 & neg \\
\hline N4026 & $9 / 28 / 83$ & $<30$ & 20 & 12,000 & $<30$ & 50 & $<1$ & $<10$ & $<50$ & 70 & neg \\
\hline N4062 & $9 / 27 / 83$ & $<30$ & 10 & 18,000 & 40 & 330 & $<1$ & $<10$ & $<50$ & 90 & neg \\
\hline N4213 & $10 / 4 / 83$ & $<30$ & 20 & 950 & -- & 60 & $<1$ & $<10$ & $<50$ & 30 & neg \\
\hline N6581 & $10 / 3 / 83$ & $<30$ & 50 & 200,000 & -- & 3,800 & $<1$ & $<10$ & $<50$ & 120 & neg \\
\hline N6701 & $10 / 5 / 83$ & $<30$ & 10 & 260 & 80 & 300 & $<1$ & $<10$ & $<50$ & 1,800 & neg \\
\hline N6707 & $9 / 28 / 83$ & $<30$ & 40 & 42,000 & 130 & 1,400 & $<1$ & $<10$ & $<50$ & 4,500 & neg \\
\hline N6792 & $9 / 28 / 83$ & $<30$ & 20 & 1,900 & $<30$ & 70 & $<1$ & $<10$ & $<50$ & 250 & neg \\
\hline N7161 & $10 / 4 / 83$ & $<30$ & 10 & 5,600 & $<30$ & 20 & 1 & $<10$ & $<50$ & 40 & neg \\
\hline N8877 & $9 / 29 / 83$ & $<30$ & 10 & 5,700 & 40 & 70 & $<1$ & $<10$ & $<50$ & 50 & neg \\
\hline
\end{tabular}

${ }^{1}$ Wells were sampled by the U S Geological Survey and ranged from 2 to 32 inches in diamter Generally, the smaller diameter wells are Geological Survey observation wells, those of larger diameter are industrial or abandoned public supply wells Sample-collection procedures were determined mainly by well diameter and depth to water Normally, where the depth to water was 25 feet or less, a centrifugal pump was used, otherwise a submersible pump was used In places where both centrifugal and submersible pumps were impractical, the samples were balled The volume of water standing in the well casing was evacuated at least three times, and specific conductance was monitored untıl stable before sampling was begun All samples were stored and preserved with appropnate chemical reagents as described by the Bureau of Water Supply Laboratory (New York City Department of Environmental Protection, written commun , 1983)

Samples were analyzed by the Bureau of Water Supply Laboratory accordıng to methods prescribed by the American Public Health Association (1976) 


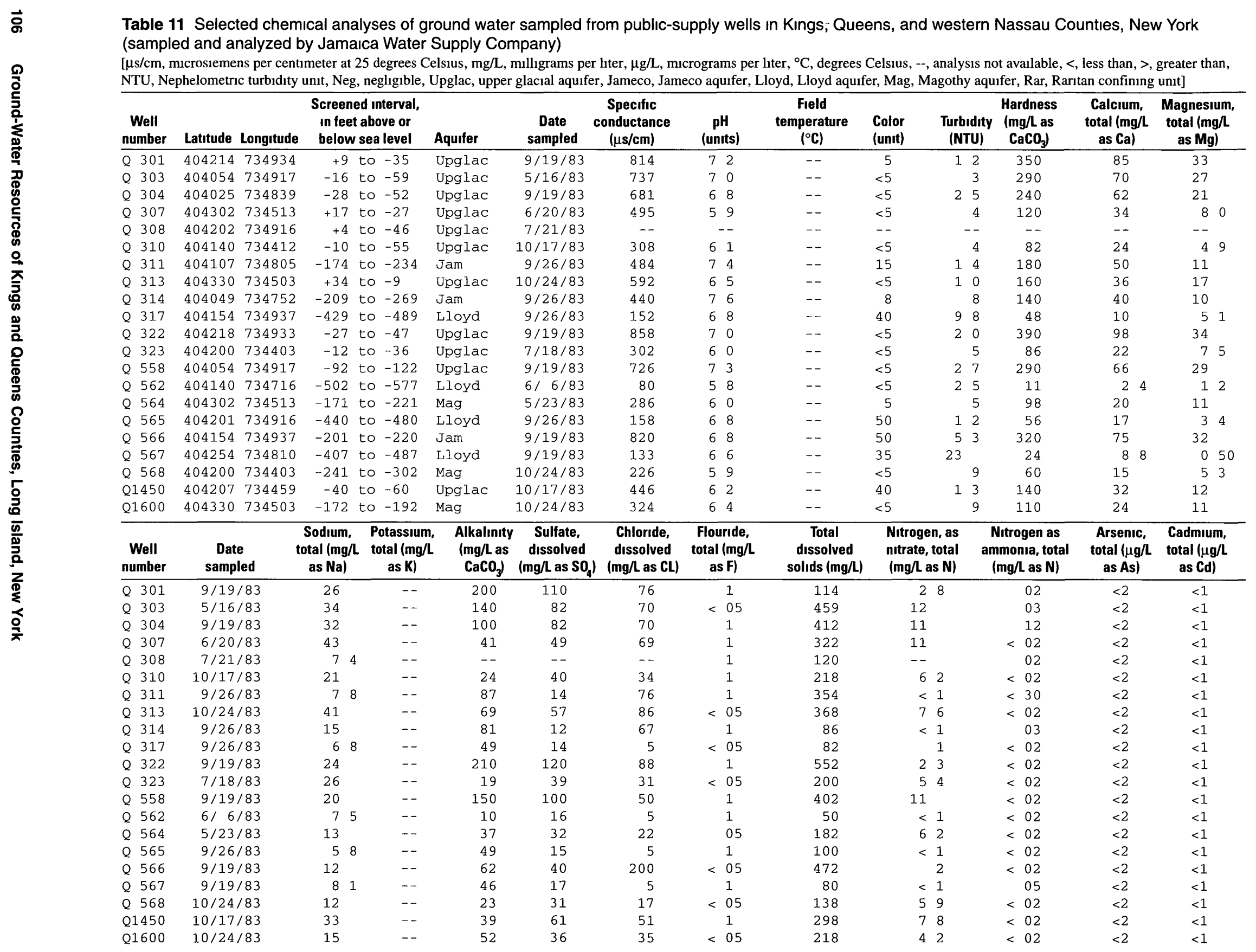


Table 11. Selected chemıcal analyses of ground water sampled from public-supply wells in Kıngs, Queens, and western Nassau Countıes, New York (sampled and analyzed by Jamaica Water Supply Company)-Contınued

$\left[\mu \mathrm{s} / \mathrm{cm}\right.$, microsiemens per centımeter at 25 degrees Celsius, $\mathrm{mg} / \mathrm{L}$, millıgrams per liter, $\mu \mathrm{g} / \mathrm{L}$, micrograms per hiter, ${ }^{\circ} \mathrm{C}$, degrees Celsius, --, analysis not avallable, $<$, less than, $>$, greater than, NTU, Nephelometric turbıdity unit, Neg, negligible, Upglac, upper glacıal aquifer, Jameco, Jameco aquifer, Lloyd, Lloyd aquifer, Mag, Magothy aquifer, Rar, Raritan confinıng unit]

\begin{tabular}{|c|c|c|c|c|c|c|c|c|c|c|c|}
\hline $\begin{array}{c}\text { Well } \\
\text { number }\end{array}$ & $\begin{array}{c}\text { Date } \\
\text { sampled }\end{array}$ & $\begin{array}{l}\text { Chromium, } \\
\text { total }(\mu \mathrm{g} / \mathrm{l} \\
\text { as } \mathrm{Cr})\end{array}$ & $\begin{array}{c}\text { Copper, } \\
\text { total }(\mu \mathrm{g} / \mathrm{L} \\
\text { as } \mathrm{Cu})\end{array}$ & $\begin{array}{c}\text { Iron, } \\
\text { total }(\mu \mathrm{g} / \mathrm{L} \\
\text { as } \mathrm{Fe}\rangle\end{array}$ & $\begin{array}{c}\text { Lead, } \\
\text { total }(\mu \mathrm{g} / \mathrm{L} \\
\text { as } \mathrm{Pb})\end{array}$ & $\begin{array}{c}\text { Manganese, } \\
\text { total }(\mu g / L \\
\text { as } M n)\end{array}$ & $\begin{array}{c}\text { Mercury, } \\
\text { total }(\mu \mathrm{g} / \mathrm{L} \\
\text { as } \mathrm{Hg})\end{array}$ & $\begin{array}{c}\text { Selenium, } \\
\text { total }(\mu \mathrm{g} / \mathrm{L} \\
\text { as } \mathrm{Se})\end{array}$ & $\begin{array}{c}\text { Silver, } \\
\text { total }(\mu \mathrm{g} / \mathrm{L} \\
\text { as } \mathrm{Ag})\end{array}$ & $\begin{array}{c}\text { Zinc, } \\
\text { total }(\mu \mathrm{g} / \mathrm{L} \\
\text { as } \mathrm{Zn})\end{array}$ & $\begin{array}{l}\text { Linear } \\
\text { alkyl } \\
\text { sulfonate }\end{array}$ \\
\hline Q 301 & $9 / 19 / 83$ & $<20$ & 20 & 90 & $<2$ & 560 & $<5$ & $<2$ & $<20$ & $<20$ & -- \\
\hline Q 303 & $5 / 16 / 83$ & $<20$ & 20 & 40 & $<2$ & $<20$ & $<5$ & $<2$ & $<20$ & $<20$ & -- \\
\hline Q 304 & $9 / 19 / 83$ & $<20$ & 440 & 220 & $<2$ & 990 & $<5$ & $<2$ & $<20$ & $<20$ & -- \\
\hline Q 307 & $6 / 20 / 83$ & $<20$ & 170 & 30 & $<2$ & $<20$ & $<5$ & $<2$ & $<20$ & $<20$ & -- \\
\hline Q 308 & $7 / 21 / 83$ & $<20$ & 200 & 1,800 & 30 & 150 & $<5$ & $<2$ & $<20$ & $<20$ & -- \\
\hline Q 310 & $10 / 17 / 83$ & $<20$ & 20 & 20 & $<2$ & $<20$ & $<5$ & $<2$ & $<20$ & $<20$ & -- \\
\hline Q 311 & $9 / 26 / 83$ & $<20$ & 20 & 1,500 & $<2$ & 880 & $<5$ & $<2$ & $<20$ & $<20$ & -- \\
\hline Q 313 & $10 / 24 / 83$ & $<20$ & 40 & 90 & $<2$ & 20 & $<5$ & $<2$ & $<20$ & $<20$ & -- \\
\hline Q 314 & $9 / 26 / 83$ & $<20$ & 20 & 190 & $<2$ & 80 & $<5$ & $<2$ & $<20$ & 20 & -- \\
\hline Q 317 & $9 / 26 / 83$ & $<20$ & 20 & 1,600 & $<2$ & 190 & $<5$ & $<2$ & 80 & 20 & -- \\
\hline Q 322 & $9 / 19 / 83$ & $<20$ & 20 & 20 & $<2$ & 380 & $<5$ & $<2$ & $<20$ & $<20$ & -- \\
\hline Q 323 & $7 / 18 / 83$ & $<20$ & 20 & 20 & $<2$ & $<20$ & $<5$ & $<2$ & $<20$ & 30 & -- \\
\hline Q 558 & $9 / 19 / 83$ & $<20$ & 20 & 20 & $<2$ & 130 & $<5$ & $<2$ & $<20$ & $<20$ & -- \\
\hline Q 562 & $6 / 6 / 83$ & $<20$ & 20 & 20 & $<2$ & $<20$ & $<5$ & $<2$ & $<20$ & 60 & -- \\
\hline Q 564 & $5 / 23 / 83$ & $<20$ & 20 & 30 & $<2$ & $<20$ & $<5$ & $<2$ & $<20$ & $<20$ & -- \\
\hline Q 565 & $9 / 26 / 83$ & $<20$ & 20 & $6 y 0$ & 2 & 350 & $<5$ & $<2$ & 40 & $<20$ & -- \\
\hline Q 566 & $9 / 19 / 83$ & $<20$ & 20 & 5,300 & $<2$ & 580 & $<5$ & $<2$ & $<20$ & $<20$ & -- \\
\hline Q 567 & $9 / 19 / 83$ & $<20$ & 150 & 2,200 & $<2$ & 140 & $<5$ & $<2$ & $<20$ & 40 & -- \\
\hline Q 568 & $10 / 24 / 83$ & $<20$ & 20 & 390 & $<2$ & 60 & $<5$ & $<2$ & $<20$ & 20 & -- \\
\hline Q1450 & $10 / 17 / 83$ & $<20$ & 30 & 1,600 & $<2$ & 370 & $<5$ & $<2$ & -- & 20 & -- \\
\hline $\mathrm{Q} 1600$ & $10 / 24 / 83$ & $<20$ & 30 & 20 & $<2$ & $<20$ & $<5$ & $<2$ & $<20$ & 30 & -- \\
\hline
\end{tabular}


Table 11 Selected chemical analyses of ground water sampled from publıc-supply wells in Kıngs, Queens, and western Nassau Countıes, New York (sampled and analyzed by Jamaica Water Supply Company)-Contınued

\begin{tabular}{|c|c|c|c|c|c|c|c|c|c|c|c|c|c|c|c|c|}
\hline \multirow{2}{*}{$\begin{array}{c}\begin{array}{c}\text { Well } \\
\text { number }\end{array} \\
\text { Q1629 }\end{array}$} & \multirow{2}{*}{$\begin{array}{l}\text { Latitude } \\
404249\end{array}$} & Longitude & \multicolumn{2}{|c|}{$\begin{array}{l}\text { Screened interval, } \\
\text { in feet above or } \\
\text { below sea level }\end{array}$} & \multirow{2}{*}{$\begin{array}{l}\text { Aquifer } \\
\text { Mag }\end{array}$} & \multirow{2}{*}{$\begin{array}{c}\begin{array}{c}\text { Date } \\
\text { sampled }\end{array} \\
3 / 28 / 83\end{array}$} & \multirow{2}{*}{$\begin{array}{c}\begin{array}{c}\text { Specific } \\
\text { conductance } \\
\text { ( } \boldsymbol{\mu s} / \mathbf{c m})\end{array} \\
264\end{array}$} & \multirow{2}{*}{\multicolumn{2}{|c|}{$\begin{array}{c}\begin{array}{c}\text { pH } \\
\text { (units) }\end{array} \\
59\end{array}$}} & \multirow{2}{*}{$\begin{array}{c}\begin{array}{c}\text { Field } \\
\text { temperature } \\
\left({ }^{\circ} \mathrm{C}\right)\end{array} \\
--\end{array}$} & \multirow{2}{*}{$\begin{array}{c}\text { Color } \\
\text { (unit) }\end{array}$} & \multicolumn{2}{|c|}{$\begin{array}{l}\text { Turbidity } \\
\text { (NTU) }\end{array}$} & \multirow{2}{*}{$\begin{array}{c}\text { Hardness } \\
\text { (mg/L as } \\
\mathrm{CaCO}_{3} \text { ) }\end{array}$} & $\begin{array}{c}\text { Calcium, } \\
\text { total (mg/L } \\
\text { as Ca) }\end{array}$ & \multirow[t]{2}{*}{$\begin{array}{c}\begin{array}{c}\text { Magnesium, } \\
\text { total (mg/L } \\
\text { as } \mathbf{M g})\end{array} \\
53\end{array}$} \\
\hline & & 734435 & -166 & to -206 & & & & & & & & & 6 & & 17 & \\
\hline Q1747 & 404323 & 734553 & -55 & to -80 & Upglac & $10 / 24 / 83$ & 462 & 6 & 8 & -- & $<5$ & & 4 & 180 & 38 & 19 \\
\hline Q1811 & 404151 & 734917 & -73 & to -93 & Upglac & $9 / 26 / 83$ & 748 & 7 & 2 & -- & 20 & 3 & 30 & 290 & 74 & 24 \\
\hline Q1815 & 404211 & 734500 & -182 & to -222 & Mag & $10 / 17 / 83$ & 275 & 6 & 0 & -- & 10 & & 8 & 72 & 19 & 56 \\
\hline Q1840 & 404057 & 734854 & -52 & to -72 & Upglac & $9 / 19 / 83$ & 640 & 7 & 0 & -- & $<5$ & & 12 & 240 & 61 & 21 \\
\hline Q1843 & 404145 & 734734 & -30 & to -50 & Upglac & $7 / 21 / 83$ & -- & & -- & -- & -- & & -. & -- & -- & -- \\
\hline Q1957 & 404250 & 734538 & -165 & to -215 & Mag & $10 / 24 / 83$ & 308 & 6 & 4 & -- & $<5$ & & 4 & 100 & 24 & 10 \\
\hline Q1958 & 404140 & 734412 & -332 & to -384 & Mag & $10 / 17 / 83$ & 158 & 5 & 9 & -- & 5 & & 4 & 45 & 96 & 51 \\
\hline Q1997 & 404248 & 734601 & -25 & to -55 & Upglac & 9/19/83 & 638 & 6 & 7 & -- & $<5$ & & 9 & 210 & 49 & 22 \\
\hline Q2000 & 404332 & 734429 & +9 & to -12 & Upglac & $5 / 23 / 83$ & 515 & 6 & 4 & -- & $<5$ & & 12 & 120 & 30 & 92 \\
\hline Q2001 & 404259 & 734634 & -44 & to -84 & Upglac & $9 / 19 / 83$ & 712 & 7 & 0 & -- & 5 & & 37 & 290 & 66 & 31 \\
\hline Q2026 & 404042 & 734336 & -357 & to -391 & Mag & $10 / 17 / 83$ & 165 & 5 & 7 & -- & 10 & & 8 & 39 & 12 & 19 \\
\hline Q2027 & 404156 & 734525 & -28 & to -38 & Upglac & $10 / 17 / 83$ & 417 & 6 & 1 & -- & $<5$ & & 4 & 110 & 34 & 53 \\
\hline Q2028 & 404156 & 734525 & -196 & to -236 & Mag & $10 / 17 / 83$ & 253 & 5 & 9 & -- & 5 & 1 & 14 & 61 & 18 & 39 \\
\hline Q2137 & 404254 & 734813 & -80 & to -120 & Mag & 9/19/83 & 654 & 6 & 8 & -- & 10 & 21 & & 280 & 62 & 30 \\
\hline Q2138 & 404204 & 735000 & -51 & to -71 & Upglac & $9 / 19 / 83$ & 742 & 7 & 0 & -- & $<5$ & & 8 & 310 & 73 & 30 \\
\hline Q2188 & 404332 & 734429 & -141 & to -181 & Mag & $10 / 24 / 83$ & 246 & 6 & 3 & -- & $<5$ & & 6 & 64 & 16 & 53 \\
\hline Q2189 & 404123 & 734930 & -72 & to -118 & Upglac & 9/19/83 & 891 & 7 & 2 & -- & $<5$ & 1 & 14 & 410 & 97 & 40 \\
\hline Q2243 & 404116 & 734521 & -43 & to -63 & Mag & $10 / 24 / 83$ & 198 & 6 & 0 & -- & $<5$ & & 8 & 66 & 21 & 29 \\
\hline Q2275 & 404216 & 734423 & -31 & to -51 & Upglac & $1 / 24 / 83$ & 368 & 6 & 0 & -- & $<5$ & & 8 & 100 & 31 & 63 \\
\hline Q2276 & 404216 & 734423 & -250 & to -290 & Mag & $10 / 24 / 83$ & 174 & 6 & 2 & -- & $<5$ & & 4 & 38 & 12 & 19 \\
\hline $\begin{array}{c}\text { Well } \\
\text { number }\end{array}$ & $\begin{array}{r}\text { Date } \\
\text { sampl }\end{array}$ & & $\begin{array}{l}\text { Sodium, } \\
\text { total (mg/l } \\
\text { as } \mathrm{Na}) \\
\end{array}$ & $\begin{array}{c}\text { Potassium, } \\
\text { total (mg/L } \\
\text { as K) }\end{array}$ & $\begin{array}{c}\text { Alkalınity } \\
(\mathrm{mg} / \mathrm{L} \text { as } \\
\left.\mathrm{CaCO}_{3}\right)\end{array}$ & $\begin{array}{c}\text { Sulfate, } \\
\text { dissolved } \\
\left(\mathrm{mg} / \mathrm{L} \text { as } \mathrm{SO}_{4}\right)\end{array}$ & 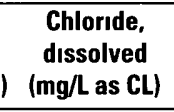 & $\begin{array}{r}\text { Flour } \\
\text { total (1 } \\
\text { as } \\
\end{array}$ & $\begin{array}{l}\text { Iride, } \\
\text { (mg/L } \\
F)\end{array}$ & $\begin{array}{c}\text { Total } \\
\text { dissolved } \\
\text { solids (mg/L) } \\
\end{array}$ & $\begin{array}{l}\text { Nitrc } \\
\text { nitra } \\
\text { (mg }\end{array}$ & $\begin{array}{l}\text { en, as } \\
\text { total } \\
\text { as N) }\end{array}$ & & $\begin{array}{l}\text { Nitrogen as } \\
\text { mmonia, total } \\
\text { (mg/L as N) }\end{array}$ & $\begin{array}{c}\text { Arsenıc, } \\
\text { total ( } \mu \mathrm{g} / \mathrm{L} \\
\text { as As) }\end{array}$ & $\begin{array}{c}\text { Cadmium, } \\
\text { total }(\mu \mathrm{g} / \mathrm{L} \\
\text { as Cd) }\end{array}$ \\
\hline Q1629 & $3 / 28 /$ & 183 & 16 & -- & 25 & 26 & 29 & & 1 & -- & & 2 & & $<02$ & $<2$ & $<1$ \\
\hline Q1747 & $10 / 24 /$ & 183 & 13 & -- & 94 & 43 & 50 & $<$ & 05 & 288 & & 4 & & $<02$ & $<2$ & $<1$ \\
\hline Q1811 & $9 / 26 /$ & 183 & 32 & -- & 190 & 85 & 60 & & 1 & 464 & & 3 & & 08 & $<2$ & $<1$ \\
\hline Q1815 & $10 / 17 /$ & 183 & 14 & -- & 20 & 43 & 24 & $<$ & 05 & 172 & & 4 & & $<02$ & $<2$ & $<1$ \\
\hline Q1840 & $9 / 19 /$ & 183 & 32 & -- & 130 & 85 & 64 & & 1 & 402 & & 8 & & $<02$ & $<2$ & $<1$ \\
\hline Q1843 & $7 / 21 /$ & 183 & 36 & -- & -- & -- & -- & & 1 & 476 & & -- & & 20 & $<2$ & $<1$ \\
\hline Q1957 & $10 / 24 /$ & 183 & 15 & -- & 45 & 36 & 35 & $<$ & 05 & 197 & & 1 & & $<02$ & $<2$ & $<1$ \\
\hline Q1958 & $10 / 17 /$ & 183 & 76 & -- & 28 & 30 & 12 & & 1 & 104 & & 4 & & $<02$ & $<2$ & $<1$ \\
\hline Q1997 & $9 / 19 /$ & 183 & 31 & -- & 110 & 70 & 68 & & 1 & 378 & & 2 & & $<02$ & $<2$ & $<1$ \\
\hline $\mathrm{Q} 2000$ & $5 / 23 /$ & 183 & 30 & -- & 84 & 49 & 52 & $<$ & 02 & 140 & & 2 & & 03 & $<2$ & $<1$ \\
\hline Q2001 & $9 / 19 /$ & 183 & 22 & -- & 170 & 85 & 67 & & 1 & 424 & & 1 & & 13 & $<2$ & $<1$ \\
\hline Q2026 & $10 / 17 /$ & /83 & 96 & -- & 60 & 36 & 90 & $<$ & 05 & 192 & & 1 & & $<02$ & $<2$ & $<1$ \\
\hline Q2027 & $10 / 17 /$ & 183 & 30 & -- & 44 & 53 & 41 & & 1 & 276 & & & & $<02$ & $<2$ & $<1$ \\
\hline Q2028 & $10 / 17 /$ & 183 & 15 & -- & 11 & 48 & 28 & & 1 & 162 & & 4 & & $<02$ & $<2$ & $<1$ \\
\hline Q2137 & $9 / 19 /$ & 183 & 14 & -- & 150 & 95 & 58 & $<$ & 05 & 404 & & 1 & & $<02$ & $<2$ & $<1$ \\
\hline Q2138 & $9 / 19 /$ & 183 & 23 & -- & 170 & 95 & 58 & & 1 & 196 & & 2 & & $<02$ & $<2$ & $<1$ \\
\hline Q2188 & $10 / 24 /$ & /83 & 11 & -- & 25 & 28 & 21 & & 1 & 98 & & 8 & & $<02$ & $<2$ & $<1$ \\
\hline Q2189 & $9 / 19 /$ & 183 & 28 & -- & 160 & 90 & 160 & $<$ & 05 & 540 & & 2 & & 03 & $<2$ & $<1$ \\
\hline Q2243 & $10 / 24 /$ & /83 & 19 & -- & 23 & 27 & 26 & & 1 & 124 & & 6 & & $<02$ & $<2$ & $<1$ \\
\hline Q2275 & $1 / 24 /$ & /83 & 26 & -- & 26 & 52 & 44 & $<$ & 05 & 206 & & 6 & & $<02$ & $<2$ & $<1$ \\
\hline Q2276 & $10 / 24 /$ & /83 & 85 & -- & 21 & 16 & 12 & $<$ & 05 & 112 & & 0 & & $<02$ & $<2$ & $<1$ \\
\hline
\end{tabular}


Table 11 Selected chemical analyses of ground water sampled from public-supply wells in Kıngs, Queens, and western Nassau Counties, New York (sampled and analyzed by Jamaıca Water Supply Company) - Contınued

$\left[\mu \mathrm{s} / \mathrm{cm}\right.$, microsiemens per centımeter at 25 degrees Celsius, $\mathrm{mg} / \mathrm{L}$, milligrams per liter, $\mu \mathrm{g} / \mathrm{L}$, micrograms per liter, ${ }^{\circ} \mathrm{C}$, degrees Celsius, -- , analysis not avalable, $<$, less than, $>$, greater than, NTU, Nephelometric turbidity unit, Neg, negligible, Upglac, upper glacial aquifer, Jameco, Jameco aquifer, Lloyd, Lloyd aquifer, Mag, Magothy aquifer, Rar, Raritan confining unit]

\begin{tabular}{|c|c|c|c|c|c|c|c|c|c|c|c|}
\hline $\begin{array}{l}\text { Well } \\
\text { number }\end{array}$ & $\begin{array}{c}\text { Date } \\
\text { sampled }\end{array}$ & $\begin{array}{c}\text { Chromium, } \\
\text { total }(\mu \mathrm{g} / \mathrm{L} \\
\text { as } \mathrm{Cr})\end{array}$ & $\begin{array}{l}\text { Copper, } \\
\text { total }(\mu \mathrm{g} / \mathrm{l} \\
\text { as Cu) }\end{array}$ & $\begin{array}{l}\text { Iron, } \\
\text { total }(\mu \mathrm{g} / \mathrm{L} \\
\text { as } \mathrm{Fe})\end{array}$ & $\begin{array}{c}\text { Lead, } \\
\text { total }(\mu \mathrm{g} / \mathrm{L} \\
\text { as } \mathrm{Pb})\end{array}$ & $\begin{array}{c}\text { Manganese, } \\
\text { total }(\mu \mathrm{g} / \mathrm{L} \\
\text { as } M n)\end{array}$ & $\begin{array}{c}\text { Mercury, } \\
\text { total }(\mu \mathrm{g} / \mathrm{L} \\
\text { as } \mathrm{Hg})\end{array}$ & $\begin{array}{c}\text { Selenium, } \\
\text { total }(\mu \mathrm{g} / \mathrm{L} \\
\text { as } \mathrm{Se})\end{array}$ & $\begin{array}{c}\text { Silver, } \\
\text { total }(\mu \mathrm{g} / \mathrm{L} \\
\text { as } \mathrm{Ag})\end{array}$ & $\begin{array}{c}\text { Zinc, } \\
\text { total }(\mu \mathrm{g} / \mathrm{L} \\
\text { as } \mathrm{Zn})\end{array}$ & $\begin{array}{l}\text { Lunear } \\
\text { alkyl } \\
\text { sulfonate }\end{array}$ \\
\hline Q1629 & $3 / 28 / 83$ & $<20$ & 20 & 20 & $<2$ & $<20$ & $<5$ & $<2$ & $<20$ & $<20$ & -- \\
\hline Q1747 & $10 / 24 / 83$ & $<20$ & 20 & 20 & $<2$ & $<20$ & $<5$ & $<2$ & $<20$ & $<20$ & -- \\
\hline Q1811 & $9 / 26 / 83$ & $<20$ & 40 & 50 & $<2$ & 490 & $<5$ & $<2$ & $<20$ & $<20$ & -. \\
\hline Q1815 & $10 / 17 / 83$ & $<20$ & 20 & 20 & $<2$ & $<20$ & $<5$ & $<2$ & $<20$ & $<20$ & -- \\
\hline Q1840 & $9 / 19 / 83$ & $<20$ & 20 & 20 & $<2$ & 160 & $<5$ & $<2$ & $<20$ & $<20$ & -. \\
\hline Q1843 & $7 / 21 / 83$ & $<20$ & 20 & 60 & $<2$ & 40 & $<5$ & $<2$ & $<20$ & 70 & -- \\
\hline Q1957 & $10 / 24 / 83$ & $<20$ & 20 & 20 & $<2$ & 70 & $<5$ & $<2$ & $<20$ & $<20$ & -- \\
\hline Q1958 & $10 / 17 / 83$ & $<20$ & 20 & 20 & 2 & $<20$ & $<5$ & $<2$ & $<20$ & $<20$ & -- \\
\hline Q1997 & $9 / 19 / 83$ & $<20$ & 20 & 40 & $<2$ & $<20$ & $<5$ & $<2$ & $<20$ & $<20$ & -- \\
\hline Q2000 & $5 / 23 / 83$ & $<20$ & 90 & 20 & $<2$ & $<20$ & $<5$ & $<2$ & $<20$ & $<20$ & -- \\
\hline Q2001 & $9 / 19 / 83$ & $<20$ & 20 & 530 & $<2$ & 340 & $<5$ & $<2$ & $<20$ & $<20$ & -- \\
\hline Q2026 & $10 / 17 / 83$ & $<20$ & 60 & 570 & $<2$ & 120 & $<5$ & $<2$ & $<20$ & 20 & -- \\
\hline Q2027 & $10 / 17 / 83$ & $<20$ & 30 & 60 & $<2$ & $<20$ & $<5$ & $<2$ & $<20$ & $<20$ & -- \\
\hline Q2028 & $10 / 17 / 83$ & $<20$ & 40 & 930 & $<2$ & 160 & $<5$ & $<2$ & $<20$ & $<20$ & -- \\
\hline Q2137 & $9 / 19 / 83$ & $<20$ & 20 & 2,200 & $<2$ & 570 & $<5$ & $<2$ & $<20$ & $<20$ & -- \\
\hline Q2138 & $9 / 19 / 83$ & $<20$ & 30 & 20 & 5 & 60 & $<5$ & $<2$ & $<20$ & 50 & -- \\
\hline Q2188 & $10 / 24 / 83$ & $<20$ & 60 & 20 & 4 & $<20$ & $<5$ & $<2$ & $<20$ & $<20$ & -- \\
\hline Q2189 & $9 / 19 / 83$ & $<20$ & 20 & 150 & $<2$ & 160 & $<5$ & $<2$ & $<20$ & $<20$ & -- \\
\hline Q2243 & $10 / 24 / 83$ & $<20$ & 20 & 70 & $<2$ & 170 & $<5$ & $<2$ & $<20$ & 60 & -- \\
\hline Q2275 & $1 / 24 / 83$ & $<20$ & 40 & 40 & $<2$ & $<20$ & $<5$ & $<2$ & $<20$ & $<20$ & -- \\
\hline Q2276 & $10 / 24 / 83$ & $<20$ & 20 & 20 & 3 & $<20$ & $<5$ & $<2$ & $<20$ & $<20$ & -- \\
\hline
\end{tabular}


Table 11 Selected chemıcal analyses of ground water sampled from publıc-supply wells in Kıngs, Queens, and western Nassau Countıes, New York (sampled and analyzed by Jamaica Water Supply Company)-Contınued

$\left[\mu \mathrm{s} / \mathrm{cm}\right.$, microsiemens per centımeter at 25 degrees Celsıus, mg/L, millıgrams per liter, $\mu \mathrm{g} / \mathrm{L}$, micrograms per liter, ${ }^{\circ} \mathrm{C}$, degrees Celsius, --, analysis not avallable, $<$, less than, $>$, greater than, NTU, Nephelometric turbidity unit, Neg, negligible, Upglac, upper glacial aquifer, Jameco, Jameco aquifer, Lloyd, Lloyd aquifer, Mag, Magothy aquifer, Rar, Raritan confining unit]

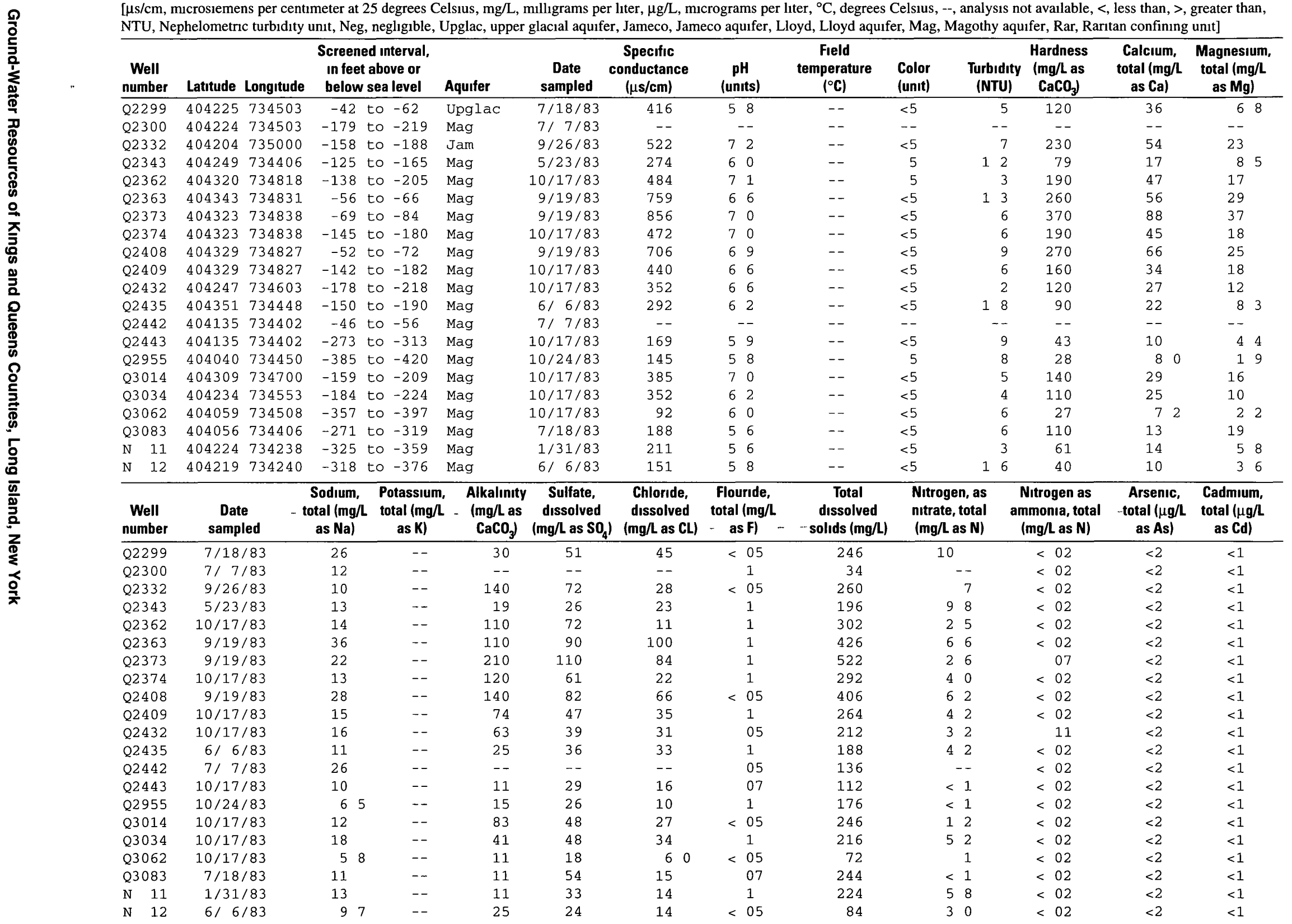


Table 11 Selected chemıcal analyses of ground water sampled from public-supply wells in Kıngs, Queens, and western Nassau Countıes, New York (sampled and analyzed by Jamaica Water Supply Company)-Contınued

$\left[\mu \mathrm{s} / \mathrm{cm}\right.$, microsiemens per centımeter at 25 degrees Celsius, mg/L, millıgrams per liter, $\mu \mathrm{g} / \mathrm{L}$, micrograms per liter, ${ }^{\circ} \mathrm{C}$, degrees Celsius, --, analysis not avallable, $<$, less than, $>$, greater than, NTU, Nephelometnc turbıdity unıt, Neg, neglıgible, Upglac, upper glacial aquifer, Jameco, Jameco aquifer, Lloyd, Lloyd aquifer, Mag, Magothy aquifer, Rar, Raritan confinıng unit]

\begin{tabular}{|c|c|c|c|c|c|c|c|c|c|c|c|}
\hline $\begin{array}{c}\text { Well } \\
\text { number }\end{array}$ & $\begin{array}{c}\text { Date } \\
\text { sampled }\end{array}$ & $\begin{array}{l}\text { Chromium, } \\
\text { total }(\mu \mathrm{g} / \mathrm{L} \\
\text { as Cr) }\end{array}$ & $\begin{array}{l}\text { Copper, } \\
\text { total ( } \mu \mathrm{g} / \mathrm{L} \\
\text { as Cu) }\end{array}$ & $\begin{array}{c}\text { Iron, } \\
\text { total }(\mu \mathrm{g} / \mathrm{L} \\
\text { as } \mathrm{Fe})\end{array}$ & $\begin{array}{c}\text { Lead, } \\
\text { total }(\mu \mathrm{g} / \mathrm{L} \\
\text { as } \mathrm{Pb})\end{array}$ & $\begin{array}{c}\text { Manganese, } \\
\text { total }(\mu \mathrm{g} / \mathrm{L} \\
\text { as } \mathrm{Mn})\end{array}$ & $\begin{array}{c}\text { Mercury, } \\
\text { total }(\mu \mathrm{g} / \mathrm{l} \\
\text { as } \mathrm{Hg})\end{array}$ & $\begin{array}{c}\text { Selenium, } \\
\text { total }(\mu \mathrm{g} / \mathrm{L} \\
\text { as } \mathrm{Se})\end{array}$ & $\begin{array}{c}\text { Silver, } \\
\text { total }(\mu \mathrm{g} / \mathrm{L} \\
\text { as } \mathrm{Ag})\end{array}$ & $\begin{array}{c}Z \text { Zinc, } \\
\text { total }(\mu \mathbf{g} / \mathbf{L} \\
\text { as } Z \mathbf{n})\end{array}$ & $\begin{array}{l}\text { Lınear } \\
\text { alkyl } \\
\text { sulfonate }\end{array}$ \\
\hline Q2299 & $7 / 18 / 83$ & $<20$ & 30 & 20 & 5 & $<20$ & $<5$ & $<2$ & $<20$ & 30 & -- \\
\hline Q2300 & $7 / 7 / 83$ & $<20$ & 30 & 20 & $<2$ & $<20$ & $<5$ & $<2$ & $<20$ & 70 & -- \\
\hline Q2332 & $9 / 26 / 83$ & $<20$ & 20 & 560 & $<2$ & 120 & $<5$ & $<2$ & $<20$ & $<20$ & -- \\
\hline Q2343 & $5 / 23 / 83$ & $<20$ & 80 & 20 & $<2$ & $<20$ & $<5$ & $<2$ & $<20$ & $<20$ & -- \\
\hline $\mathrm{Q} 2362$ & $10 / 17 / 83$ & $<20$ & 30 & 20 & 2 & $<20$ & $<5$ & $<2$ & $<20$ & $<20$ & -- \\
\hline $\mathrm{Q} 2363$ & $9 / 19 / 83$ & $<20$ & 20 & 20 & $<2$ & $<20$ & $<5$ & $<2$ & $<20$ & $<20$ & -- \\
\hline Q2373 & $9 / 19 / 83$ & $<20$ & 20 & 20 & $<2$ & 160 & $<5$ & $<2$ & $<20$ & $<20$ & -- \\
\hline Q2374 & $10 / 17 / 83$ & $<20$ & 20 & 30 & $<2$ & $<20$ & $<5$ & $<2$ & $<20$ & $<20$ & -- \\
\hline Q2408 & $9 / 19 / 83$ & $<20$ & 20 & 20 & $<2$ & $<20$ & $<5$ & $<2$ & $<20$ & $<20$ & -- \\
\hline Q2409 & $10 / 17 / 83$ & $<20$ & 20 & 20 & $<2$ & $<20$ & $<5$ & $<2$ & $<20$ & $<20$ & -- \\
\hline $\mathrm{Q} 2432$ & $10 / 17 / 83$ & $<20$ & 20 & 20 & $<2$ & $<20$ & $<5$ & $<2$ & $<20$ & $<20$ & -- \\
\hline Q2435 & $6 / 6 / 83$ & $<20$ & 20 & 20 & $<2$ & $<20$ & $<5$ & $<2$ & $<20$ & $<20$ & -- \\
\hline Q2442 & $7 / 7 / 83$ & $<20$ & 20 & 60 & $<2$ & $<20$ & $<5$ & $<2$ & $<20$ & $<20$ & -- \\
\hline Q2443 & $10 / 17 / 83$ & $<20$ & 20 & 700 & $<2$ & 100 & $<5$ & $<2$ & $<20$ & $<20$ & -- \\
\hline Q2955 & $10 / 24 / 83$ & $<20$ & 20 & 460 & $<2$ & 100 & $<5$ & $<2$ & $<20$ & $<20$ & -- \\
\hline Q3014 & $10 / 17 / 83$ & $<20$ & 40 & 60 & $<2$ & $<20$ & $<5$ & $<2$ & $<20$ & $<20$ & -- \\
\hline Q3034 & $10 / 17 / 83$ & $<20$ & 20 & 20 & $<2$ & $<20$ & $<5$ & $<2$ & $<20$ & $<20$ & -- \\
\hline Q3062 & $10 / 17 / 83$ & $<20$ & 20 & 40 & $<2$ & $<20$ & $<5$ & $<2$ & $<20$ & $<20$ & -- \\
\hline Q3083 & $7 / 18 / 83$ & $<20$ & 30 & 2,200 & $<2$ & 210 & $<5$ & $<2$ & $<20$ & $<20$ & -- \\
\hline N 11 & $1 / 31 / 83$ & $<20$ & 30 & 20 & $<2$ & $<20$ & 5 & $<2$ & $<20$ & $<20$ & -- \\
\hline $\mathrm{N} \quad 12$ & $6 / 6 / 83$ & $<20$ & 30 & 50 & 4 & $<20$ & $<5$ & $<2$ & $<20$ & $<20$ & -- \\
\hline
\end{tabular}




\begin{tabular}{|c|c|c|c|c|c|c|c|c|c|c|c|c|c|c|c|c|c|c|}
\hline \multicolumn{19}{|c|}{$\begin{array}{l}\text { (sampled and analyzed by Jamaica Water Supply Company)—Contınued } \\
{\left[\mu \mathrm{s} / \mathrm{cm} \text {, microsiemens per centımeter at } 25 \text { degrees Celsius, mg/L, milligrams per liter, } \mu \mathrm{g} / \mathrm{L}, \text { micrograms per }{ }^{\prime 1 t e r},{ }^{\circ} \mathrm{C} \text {, degrees Celsius, --, analysis not avallable, }<, \text { less than, }>\text {, greater than, }\right.} \\
\text { NTU, Nephelometric turbidity unit, Neg, negligible, Upglac, upper glacial aquifer, Jameco, Jameco aquifer, Lloyd, Lloyd aquifer, Mag, Magothy aquifer, Rar, Raritan confining unit] }\end{array}$} \\
\hline $\begin{array}{c}\text { Well } \\
\text { number }\end{array}$ & \multirow{2}{*}{$\frac{\text { Latitude }}{404214}$} & Longıtude & \multicolumn{3}{|c|}{$\begin{array}{c}\text { Screened interval, } \\
\text { in feet above or } \\
\text { below sea level }\end{array}$} & \multicolumn{2}{|c|}{ Aquifer } & \multirow{2}{*}{$\begin{array}{c}\text { Date } \\
\text { sampled }\end{array}$} & \multirow{2}{*}{$\begin{array}{c}\begin{array}{c}\text { Specific } \\
\text { conductance } \\
(\mu \mathbf{s} / \mathbf{c m})\end{array} \\
297\end{array}$} & \multicolumn{2}{|c|}{$\begin{array}{c}\mathrm{pH} \\
\text { (units) }\end{array}$} & \multirow{2}{*}{$\begin{array}{l}\text { Field } \\
\text { temperature } \\
\left({ }^{\circ} \mathrm{C}\right)\end{array}$} & \multirow{2}{*}{$\begin{array}{c}\text { Color } \\
\text { (unit) }\end{array}$} & \multicolumn{2}{|c|}{$\begin{array}{c}\text { Turbidity } \\
\text { (NTU) }\end{array}$} & \multirow[t]{2}{*}{$\begin{array}{c}\begin{array}{c}\text { Hardness } \\
(\mathrm{mg} / \mathrm{L} \text { as }\end{array} \\
\left.\mathrm{CaCO}_{3}\right)\end{array}$} & \multirow{2}{*}{$\begin{array}{c}\begin{array}{c}\text { Calcium, } \\
\text { total (mg/L } \\
\text { as Ca) }\end{array} \\
18\end{array}$} & \multirow{2}{*}{$\begin{array}{c}\begin{array}{c}\text { Magnesium } \\
\text { total (mg/L } \\
\text { as } \mathbf{M g})\end{array} \\
83\end{array}$} \\
\hline N 13 & & 734241 & -182 & to & -240 & Ma & & & & & 6 & & & 3 & 5 & & & \\
\hline 14 & 404411 & 734137 & +14 & to & -7 & & glac & $7 / 18 / 83$ & 308 & & 9 & -- & $<5$ & & 7 & 98 & 31 & 49 \\
\hline N 17 & 404437 & 734023 & -304 & to & -364 & Ma & & $1 / 31 / 83$ & 286 & & 7 & -- & $<5$ & & 6 & 61 & 18 & 34 \\
\hline N 693 & 404229 & 734244 & -18 & to & -43 & & glac & $3 / 28 / 83$ & 420 & 5 & 8 & -- & $<5$ & & 6 & 130 & 32 & 10 \\
\hline N1958 & 404426 & 734148 & -551 & to & -611 & & oyd & $1 / 31 / 83$ & 48 & & 2 & -- & $<5$ & & 5 & 12 & 4 & -- \\
\hline N2115 & 404106 & 734329 & -36 & to & -56 & & glac & $7 / 18 / 83$ & 410 & 5 & 8 & -- & $<5$ & & 6 & 96 & 31 & 43 \\
\hline N2413 & 404125 & 734210 & -427 & to & -457 & Ma & & $7 / 18 / 83$ & 121 & 5 & 4 & -- & $<5$ & & 6 & 14 & 4 & 10 \\
\hline N2414 & 404124 & 734210 & -18 & to & -38 & & glac & $3 / 28 / 83$ & 204 & 5 & 5 & -- & $<5$ & & 4 & 52 & 15 & 34 \\
\hline N3720 & 404112 & 734041 & -443 & to & -483 & Ma & & $1 / 31 / 83$ & 63 & 5 & 2 & -- & $<5$ & & 5 & 14 & 4 & 10 \\
\hline N4 077 & 404323 & 734138 & +15 & to & -5 & & glac & $3 / 28 / 83$ & 226 & 5 & 6 & -- & $<5$ & & 2 & 58 & 16 & 39 \\
\hline N4298 & 404323 & 734138 & -264 & to & -299 & Ma & & $1 / 31 / 83$ & 213 & 5 & 8 & -- & $<5$ & & 3 & 59 & 16 & 44 \\
\hline N4390 & 404514 & 734121 & -137 & to & -172 & Ma & & $1 / 31 / 83$ & 308 & 6 & 0 & -- & $<5$ & & 4 & 90 & 25 & 66 \\
\hline N4512 & 404100 & 734122 & -415 & to & -465 & Ma & & $1 / 31 / 83$ & 87 & & 3 & -- & $<5$ & & 4 & 26 & 8 & 15 \\
\hline N5155 & 404238 & 734203 & +1 & to & -19 & & glac & $7 / 18 / 83$ & 336 & & 1 & -- & $<5$ & 2 & 6 & 61 & 17 & 44 \\
\hline N5156 & 404238 & 734203 & -220 & to & -260 & Ma & & $6 / 6 / 83$ & 152 & 5 & 5 & -- & $<5$ & 2 & 8 & 44 & 10 & 41 \\
\hline N6744 & 404238 & 734205 & -4 & to & -24 & & glac & $7 / 18 / 83$ & 352 & 7 & 1 & -- & 30 & 16 & & 59 & 18 & 34 \\
\hline N6745 & 404239 & 734202 & -234 & to & -274 & Ma & & $7 / 18 / 83$ & 180 & & 6 & -- & $<5$ & & 9 & 49 & 14 & 29 \\
\hline N7445 & 404514 & 734121 & -268 & to & -328 & Ma & & $6 / 6 / 83$ & 94 & 6 & 2 & -- & $<5$ & 1 & 0 & 27 & 68 & 24 \\
\hline N7482 & 404109 & 734329 & -367 & to & -407 & Ma & & $3 / 28 / 83$ & 139 & 5 & 5 & -- & $<5$ & & 6 & 36 & 88 & 34 \\
\hline N7649 & 404344 & 734121 & -65 & to & -105 & Ma & & $1 / 31 / 83$ & 132 & & 8 & -- & $<5$ & & 4 & 31 & 8 & 27 \\
\hline N7650 & 404344 & 734121 & -300 & to & -340 & Ma & & $1 / 24 / 83$ & 143 & 5 & 8 & -- & $<5$ & & 4 & 24 & 64 & 19 \\
\hline $\begin{array}{c}\text { Well } \\
\text { number }\end{array}$ & $\begin{array}{r}\text { Date } \\
\text { sample }\end{array}$ & & $\begin{array}{l}\text { Sodium, } \\
\text { otal (mg/l } \\
\text { as } \mathrm{Na} \text { ) }\end{array}$ & Po & $\begin{array}{l}\text { otassiun } \\
\text { otal (mg/ } \\
\text { as K) }\end{array}$ & & $\begin{array}{l}\text { Alkalınity } \\
\text { (mg/L as } \\
\left.\mathrm{CaCO}_{3}\right)\end{array}$ & $\begin{array}{c}\text { Sulfate, } \\
\text { dissolved } \\
\left(\mathrm{mg} / \mathrm{L} \text { as } \mathrm{SO}_{4}\right) \\
\end{array}$ & $\begin{array}{c}\text { Chloride, } \\
\text { dissolved } \\
\text { (mg/L as CL) }\end{array}$ & $\begin{array}{r}\text { Flou } \\
\text { total } \\
\text { as } \\
\end{array}$ & $\begin{array}{l}\text { uride, } \\
\text { (mg/L } \\
\text { S F) }\end{array}$ & $\begin{array}{c}\text { Total } \\
\text { dissolved } \\
\text { solıds (mg/L) } \\
\end{array}$ & $\begin{array}{l}\text { Nitri } \\
\text { nitra } \\
\text { (mg }\end{array}$ & $\begin{array}{l}\text { en, as } \\
\text { total } \\
\text { as N) }\end{array}$ & & $\begin{array}{l}\text { Nitrogen as } \\
\text { mmonia, total } \\
\text { (mg/L as N) }\end{array}$ & $\begin{array}{c}\text { Arsenic, } \\
\text { total }(\mu \mathrm{g} / \mathrm{L} \\
\text { as As) }\end{array}$ & $\begin{array}{c}\text { Cadmium, } \\
\text { total }(\mu \mathrm{g} / \mathrm{L} \\
\text { as Cd) }\end{array}$ \\
\hline $\mathrm{N} \quad 13$ & $7 / 18 / 8$ & 183 & 14 & & -- & & 13 & 63 & 18 & $<$ & 05 & 158 & & 0 & & $<02$ & $<2$ & $<1$ \\
\hline N 14 & $7 / 18 /$ & 183 & 19 & & -- & & 26 & 43 & 26 & & 06 & 227 & & 2 & & $<02$ & $<2$ & $<1$ \\
\hline N 17 & $1 / 31 / 8$ & $/ 83$ & 25 & & -- & & 14 & 28 & 40 & $<$ & 05 & 178 & & 8 & & $<02$ & $<2$ & $<1$ \\
\hline N 693 & $3 / 28 / 8$ & $/ 83$ & 30 & & -- & & 22 & 57 & 48 & $<$ & 05 & 266 & & 8 & & $<02$ & $<2$ & $<1$ \\
\hline N1958 & $1 / 31 / \varepsilon$ & $/ 83$ & 32 & 2 & -- & & 6 & 6 & 3 & $<$ & 05 & 34 & & 1 & & $<02$ & $<2$ & $<1$ \\
\hline N2115 & $7 / 18 / 8$ & $/ 83$ & 28 & & -- & & 36 & 42 & 56 & $<$ & 05 & 242 & & 6 & & $<02$ & $<2$ & $<1$ \\
\hline N2413 & $7 / 18 / 8$ & 183 & 56 & 6 & -- & & 8 & 24 & 8 & & 06 & 62 & & 4 & & $<02$ & $<2$ & $<1$ \\
\hline N2414 & $3 / 28 / 8$ & $/ 83$ & 12 & & -- & & 18 & 33 & 16 & $<$ & 05 & 142 & & 1 & & 03 & $<2$ & $<1$ \\
\hline N3720 & $1 / 31 / 8$ & $/ 83$ & 46 & 6 & -- & & 8 & 12 & 3 & $<$ & 05 & 46 & & 1 & & $<02$ & $<2$ & $<1$ \\
\hline N4 077 & $3 / 28 / 8$ & 183 & 16 & & -- & & 16 & 24 & 25 & & 1 & 104 & & 7 & & $<02$ & $<2$ & $<1$ \\
\hline N4298 & $1 / 31 / 8$ & 183 & 16 & & -- & ' & 14 & 25 & 26 & $<$ & 05 & 144 & & 2 & & $<02$ & $<2$ & $<1$ \\
\hline N4390 & $1 / 31 / 8$ & 183 & 19 & & -- & & 39 & 30 & 35 & $<$ & 05 & 206 & & 4 & & $<02$ & $<2$ & $<1$ \\
\hline N4512 & $1 / 31 / 8$ & 183 & 58 & 8 & -- & & 6 & 19 & 9 & $<$ & 05 & 52 & & 1 & & $<02$ & $<2$ & $<1$ \\
\hline N5155 & $7 / 18 / 8$ & 183 & 44 & & -- & - & 62 & 36 & 24 & & 1 & 246 & & 4 & & $<02$ & $<2$ & $<1$ \\
\hline N5156 & $6 / 6 / 8$ & 183 & 10 & & -- & & 15 & 21 & 22 & $<$ & 05 & 110 & & 5 & & $<02$ & $<2$ & $<1$ \\
\hline N6744 & $7 / 18 / 8$ & $/ 83$ & 79 & & -- & & 62 & 38 & 31 & & 1 & 72 & & 4 & - & $<02$ & 6 & $<1$ \\
\hline N6745 & $7 / 18 / 8$ & $/ 83$ & 10 & & -- & & 19 & 24 & 18 & $<$ & 05 & 104 & & 6 & & $<02$ & $<2$ & $<1$ \\
\hline N7445 & $6 / 6 / 8$ & $/ 83$ & 57 & 7 & -- & & 21 & 4 & 8 & $<$ & 05 & 68 & & 7 & & $<02$ & $<2$ & $<1$ \\
\hline N748 & $3 / 28 / 8$ & $/ 83$ & 84 & 4 & -- & & 25 & 27 & 11 & & 07 & 80 & & 1 & & 08 & $<2$ & $<1$ \\
\hline N7649 & $1 / 31 / 8$ & $/ 83$ & 77 & 7. & -- & & 10 & 6 & 10 & $<$ & 05 & 86 & & 6 & & -- & $<2$ & $<1$ \\
\hline N7 650 & $1 / 24 /$ & & 76 & & -- & & 10 & 6 & 14 & & 05 & 76 & & & & $<02$ & $<2$ & $<1$ \\
\hline
\end{tabular}


Table 11. Selected chemical analyses of ground water sampled from public-supply wells in Kıngs, Queens, and western Nassau Countıes, New York (sampled and analyzed by Jamaica Water Supply Company)-Contınued

$\left[\mu \mathrm{s} / \mathrm{cm}\right.$, microsiemens per centımeter at 25 degrees Celsıus, $\mathrm{mg} / \mathrm{L}$, mlligrams per liter, $\mu \mathrm{g} / \mathrm{L}$, micrograms per liter, ${ }^{\circ} \mathrm{C}$, degrees Celsius, --, analysis not avallable, $<$, less than, $>$, greater than, NTU, Nephelometnc turbidity unit, Neg, negligible, Upglac, upper glacial aquifer, Jameco, Jameco aquifer, Lloyd, Lloyd aquifer, Mag, Magothy aquifer, Rar, Raritan confining unit]

\begin{tabular}{|c|c|c|c|c|c|c|c|c|c|c|c|}
\hline $\begin{array}{l}\text { Well } \\
\text { number }\end{array}$ & $\begin{array}{c}\text { Date } \\
\text { sampled }\end{array}$ & $\begin{array}{c}\text { Chromıum, } \\
\text { total }(\mu \mathrm{g} / \mathrm{L} \\
\text { as Cr) }\end{array}$ & $\begin{array}{l}\text { Copper, } \\
\text { total }(\mu \mathrm{g} / \mathrm{L} \\
\text { as } \mathrm{Cu})\end{array}$ & $\begin{array}{c}\text { Iron, } \\
\text { total }(\mu \mathrm{g} / \mathrm{h} \\
\text { as } \mathrm{Fe})\end{array}$ & $\begin{array}{l}\text { Lead, } \\
\text { total }(\mu \mathrm{g} / \mathrm{L} \\
\text { as } \mathrm{Pb})\end{array}$ & $\begin{array}{c}\text { Manganese, } \\
\text { total }(\mu \mathrm{g} / \mathrm{L} \\
\text { as } \mathrm{Mn})\end{array}$ & $\begin{array}{c}\text { Mercury, } \\
\text { total }(\mu \mathrm{g} / \mathrm{L} \\
\text { as } \mathrm{Hg})\end{array}$ & $\begin{array}{l}\text { Selenium, } \\
\text { total }(\mu \mathrm{g} / \mathrm{L} \\
\text { as } \mathrm{Se})\end{array}$ & $\begin{array}{l}\text { Silver, } \\
\text { total }(\mu \mathrm{g} / \mathrm{L} \\
\text { as Ag) }\end{array}$ & $\begin{array}{c}\text { Zınc, } \\
\text { total }(\mu \mathrm{g} / \mathrm{L} \\
\text { as } \mathrm{Zn})\end{array}$ & $\begin{array}{c}\text { Linear } \\
\text { alkyl } \\
\text { sulfonate }\end{array}$ \\
\hline N 13 & $7 / 18 / 83$ & $<20$ & 20 & 140 & $<2$ & $<20$ & $<5$ & $<2$ & $<20$ & $<20$ & -- \\
\hline $\mathrm{N} \quad 14$ & $7 / 18 / 83$ & $<20$ & 30 & 20 & $<2$ & $<20$ & $<5$ & $<2$ & $<20$ & $<20$ & -- \\
\hline N 17 & $1 / 31 / 83$ & $<20$ & 30 & 40 & $<2$ & $<20$ & $<5$ & $<2$ & $<20$ & $<20$ & -- \\
\hline N 693 & $3 / 28 / 83$ & $<20$ & 20 & 20 & $<2$ & $<20$ & $<5$ & $<2$ & $<20$ & $<20$ & -- \\
\hline N1958 & $1 / 31 / 83$ & $<20$ & 20 & 20 & $<2$ & $<20$ & $<5$ & $<2$ & $<20$ & 40 & -. \\
\hline N2115 & $7 / 18 / 83$ & $<20$ & 20 & 20 & $<2$ & 60 & $<5$ & $<2$ & $<20$ & $<20$ & -- \\
\hline N2413 & $7 / 18 / 83$ & $<20$ & 20 & 350 & $<2$ & 30 & $<5$ & $<2$ & $<20$ & $<20$ & -- \\
\hline N2414 & $3 / 28 / 83$ & $<20$ & 20 & 20 & $<2$ & $<20$ & $<5$ & $<2$ & $<20$ & $<20$ & -- \\
\hline N3720 & $1 / 31 / 83$ & $<20$ & 20 & 180 & $<2$ & 20 & $<5$ & $<2$ & $<20$ & $<20$ & -- \\
\hline N4077 & $3 / 28 / 83$ & $<20$ & 170 & 20 & 3 & $<20$ & $<5$ & $<2$ & $<20$ & $<20$ & -- \\
\hline N4298 & $1 / 31 / 83$ & $<20$ & 20 & 20 & 2 & $<20$ & $<5$ & $<2$ & $<20$ & $<20$ & -- \\
\hline N4390 & $1 / 31 / 83$ & $<20$ & 20 & 20 & 2 & $<20$ & $<5$ & $<2$ & $<20$ & $<20$ & -- \\
\hline N4512 & $1 / 31 / 83$ & $<20$ & 20 & 430 & $<2$ & $<20$ & $<5$ & $<2$ & $<20$ & $<20$ & -- \\
\hline N5155 & $7 / 18 / 83$ & $<20$ & 40 & 30 & $<2$ & $<20$ & $<5$ & $<2$ & $<20$ & $<20$ & -- \\
\hline N5156 & $6 / 6 / 83$ & $<20$ & 20 & 20 & $<2$ & 30 & $<5$ & $<2$ & $<20$ & -- & -- \\
\hline N6744 & $7 / 18 / 83$ & $<20$ & 20 & 30 & $<2$ & $<20$ & $<5$ & $<2$ & $<20$ & $<20$ & -- \\
\hline N6745 & $7 / 18 / 83$ & $<20$ & 30 & 20 & $<2$ & $<20$ & $<5$ & $<2$ & $<20$ & $<20$ & -- \\
\hline N7445 & $6 / 6 / 83$ & $<20$ & 20 & 20 & $<2$ & $<20$ & $<5$ & $<2$ & $<20$ & $<20$ & -- \\
\hline N7482 & $3 / 28 / 83$ & $<20$ & 20 & 190 & $<2$ & 60 & $<5$ & $<2$ & $<20$ & $<20$ & -- \\
\hline N7649 & $1 / 31 / 83$ & $<20$ & 20 & 20 & $<2$ & $<20$ & $<5$ & $<2$ & $<20$ & $<20$ & -- \\
\hline N7650 & $1 / 24 / 83$ & $<20$ & 20 & 20 & $<2$ & $<20$ & $<5$ & $<2$ & $<20$ & $<20$ & -- \\
\hline
\end{tabular}




\section{Selected Series of U.S. Geological Survey Publications}

\section{Books and Other Publications}

1. Professional Papers report scientific data and interpretations of lasting scientific interest that cover all facets of USGS investigations and research.

Bulletins contain significant data and interpretations that are of

- lasting scientific interest but are generally more limited in scope or geographic coverage than Professional Papers.

Water-Supply Papers are comprehensive reports that present significant interpretive results of hydrologic investigations of wide interest to professional geologists, hydrologists, and engineers. The series covers investigations in all phases of hydrology, including hydrogeology, availability of water, quality of water, and use of water.

Circulars are reports of programmatic or scientific information of an ephemeral nature; many present important scientific information of wide popular interest. Circulars are distributed at no cost to the public.

Fact Sheets communicate a wide variety of timely information on USGS programs, projects, and research. They commonly address issues of public interest. Fact Sheets generally are two or four pages long and are distributed at no cost to the public.

Reports in the Digital Data Series (DDS) distribute large amounts of data through digital media, including compact discread-only memory (CD-ROM). They are high-quality, interpretive publications designed as self-contained packages for viewing and interpreting data and typically contain data sets, software to view the data, and explanatory text.

Water-Resources Investigations Reports are papers of an interpretive nature made available to the public outside the formal USGS publications series. Copies are produced on request (unlike formal USGS publications) and are also available for public inspection at depositories indicated in USGS catalogs.

Open-File Reports can consist of basic data, preliminary reports, and a wide range of scientific documents on USGS investigations. Open-File Reports are designed for fast release and are available for public consultation at depositories.

\section{Maps}

Geologic Quadrangle Maps (GQ's) are multicolor geologic maps on topographic bases in 7.5- or 15-minute quadrangle formats (scales mainly 1:24,000 or 1:62,500) showing bedrock, surficial, or engineering geology. Maps generally include brief texts; some maps include structure and columnar sections only.

Geophysical Investigations Maps (GP's) are on topographic or planimetric bases at various scales. They show results of geophysical investigations using gravity, magnetic, seismic, or radioactivity surveys, which provide data on subsurface structures that are of economic or geologic significance.
Miscellaneous Investigations Series Maps or Geologic Investigations Series (I's) are on planimetric or topographic bases at various scales; they present a wide variety of format and subject matter. The series also incudes 7.5-minute quadrangle photogeologic maps on planimetric bases and planetary maps.

\section{Information Periodicals}

Metal Industry Indicators (MII's) is a free monthly newsletter that analyzes and forecasts the economic health of five metal industries with composite leading and coincident indexes: primary metals, steel, copper, primary and secondary aluminum, and aluminum mill products.

Mineral Industry Surveys (MIS's) are free periodic statistical and economic reports designed to provide timely statistical data on production, distribution, stocks, and consumption of significant mineral commodities. The surveys are issued monthly, quarterly, annually, or at other regular intervals, depending on the need for current data. The MIS's are published by commodity as well as by State. A series of international MIS's is also available.

Published on an annual basis, Mineral Commodity Summaries is the earliest Government publication to furnish estimates covering nonfuel mineral industry data. Data sheets contain information on the domestic industry structure, Government programs, tariffs, and 5-year salient statistics for more than 90 individual minerals and materials.

The Minerals Yearbook discusses the performance of the worldwide minerals and materials industry during a calendar year, and it provides background information to assist in interpreting that performance. The Minerals Yearbook consists of three volumes. Volume I, Metals and Minerals, contains chapters about virtually all metallic and industrial mineral commodities important to the U.S. economy. Volume II, Area Reports: Domestic, contains a chapter on the minerals industry of each of the 50 States and Puerto Rico and the Administered Islands. Volume III, Area Reports: International, is published as four separate reports. These reports collectively contain the latest available mineral data on more than 190 foreign countries and discuss the importance of minerals to the economies of these nations and the United States.

\section{Permanent Catalogs}

"Publications of the U.S. Geological Survey, 1879-1961" and "Publications of the U.S. Geological Survey, 19621970" are available in paperback book form and as a set of microfiche.

"Publications of the U.S. Geological Survey, 1971-1981" is available in paperback book form (two volumes, publications listing and index) and as a set of microfiche.

Annual supplements for 1982, 1983, 1984, 1985, 1986, and subsequent years are available in paperback book form. 


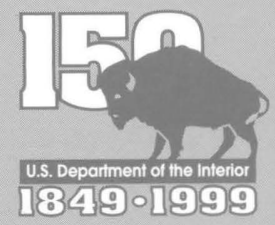

ISBN 0-607-92475-0

|| |||||||||||||||||| ||||||| 